Supporting Information

\title{
Synthesis of ketodeoxysugars from acylated pyranosides using photoredox catalysis and hydrogen atom transfer
}

\author{
Julia A. Turner, Nicholas Rosano, Daniel J. Gorelik and Mark S. Taylor* \\ mtaylor@chem.utoronto.ca \\ Department of Chemistry, University of Toronto, 80 St. George St., Toronto, ON M5S 3H6, \\ Canada
}




\section{Table of Contents}

General Information.............................................................. S4

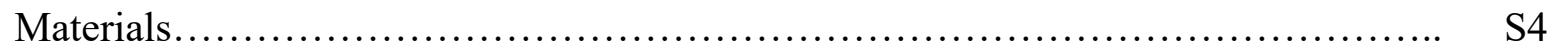

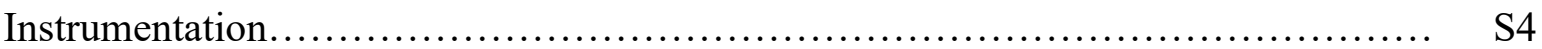

Preparation of Hydrogen Bond Acceptors .......................................... S5

General Procedure A for preparation of hydrogen bond acceptor catalysts............ S S5

Tetrabutylammonium 4-chlorobenzoate................................... S5

Tetrabutylammonium trimethylacetate................................... S5

Tetrabutylammonium $2,3,4,5$-tetrafluorobenzoate $\ldots \ldots \ldots \ldots \ldots \ldots \ldots \ldots \ldots \ldots \ldots$ S6

Tetrabutylammonium 3,4,5-trifluorobenzoate ............................ S6

Sodium dibutylphosphate............................................ S6

Tetrabutylammonium dibutylphosphate................................. S7

Tetrabutylammonium diphenylphosphate.............................. S7

$\begin{array}{ll}\text { Preparation of Substrates } & \text { S8 }\end{array}$

General Procedure B for monoacylation of carbohydrates........................ S 8

General Procedure $\mathrm{C}$ for monoacylation of carbohydrates.......................... S8

2a - Methyl 2- $O$-trimethylacetyl- $\alpha$-D-glucopyranoside...................... S9

$3 \mathrm{a}$ - Methyl 2-O-benzoyl- $\alpha$-D-glucopyranoside........................... S9

$3 \mathrm{~b}$ - Methyl 2-O-(tert-butyloxycarbonyl) $\alpha$-D-glucopyranoside................. S9

$3 \mathrm{c}$ - Methyl 2- $O$-tosyl- $\alpha$-D-glucopyranoside.............................. S10

$2 \mathrm{~b}$ - Methyl 2-O-trimethylacetyl-6-O-(tert-butyldimethylsilyl)- $\alpha$-D-

glucopyranoside................................................... S10

2c-Methyl 2,6-di- $O$-trimethylacetyl- $\alpha$-D-glucopyranoside................... S11

$2 \mathrm{~d} \quad-\quad$ Methyl 2-O-Trimethylacetyl-6-O-(2',3',4',6'-tetra-O-acetyl- $\beta$-Dgalactopyranosyl)- $\alpha$-D-glucopyranoside................................. S11

2e - Methyl 2-O-trimethylacetyl-6-O-(tert-butyldimethylsilyl)- $\alpha$-D-

galactopyranoside.................................................. S12

$2 \mathrm{f}$ - Methyl 2- $O$-benzoyl-6- $O$-(tert-butyldimethylsilyl)- $\alpha$-D-mannopyranoside.... $\quad \mathrm{S} 13$

$2 \mathrm{~g}$ - Methyl 4-O-trimethylacetyl-6-O-(tert-butyldimethylsilyl)- $\alpha$-D-

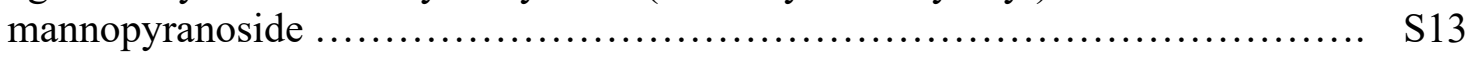

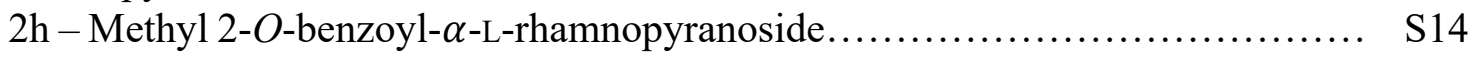

$2 \mathrm{i}$ - Cyclohexyl 2-O-benzoyl- $\alpha$-L-rhamnopyranoside....................... S14

$2 \mathrm{j}$ - 1,2,3,4-di-O-isopropylidene-6-O-(2-O-benzoyl- $\alpha$-L-rhamnopyranosyl)- $\alpha$-D-

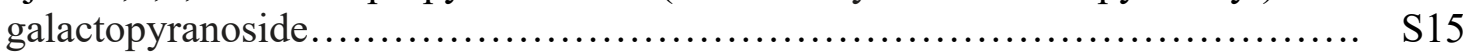

$2 \mathrm{k}$ - Methyl 4-O-benzoyl- $\alpha$-L-rhamnopyranoside.......................... S17

21 - Methyl 2-O-trimethylacteyl- $\beta$-D-glucopyranoside....................... S17

$2 \mathrm{~m}$ - Methyl 2,6-di-O-trimethylacteyl- $\beta$-D-glucopyranoside................... S18

Reaction Optimization ........................................................... S19

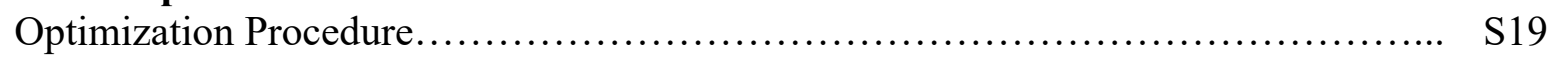

Table S1. Optimization of Hydrogen Bond Acceptor Catalyst................. S20

Table S2. Control Reactions......................................... S21

Table S3. Effects on the ratio HBA catalyst to quinuclidine on the yield of $4 a \ldots . . . \quad$ S21

Characterization of Products....................................................... S22

General Procedure D for reactions run with solid acylated sugar.................. S22

General Procedure E for reactions run with non-solid acylated sugar............... S22 
$4 a$ - Methyl 2-deoxy- $\alpha$-D-erythro-hexopyranoside-3-ulose

$4 \mathrm{~b}$ - Methyl 2-deoxy-6-O-(tert-butyldimethylsilyl)- $\alpha$-D-erythro-hexopyranoside3-ulose.

$4 \mathrm{c}$ - Methyl 2-deoxy-6-O-trimethylacetyl- $\alpha$-D-erythro-hexopyranoside-3-ulose... $4 \mathrm{~d}$ - Methyl 6-O-(2',3',4',6'-tetra-O-acetyl- $\beta$-D-galactopyranosyl)- $\alpha$-D-erythrohexopyranoside-3-ulose.

4e - Methyl 4-deoxy-6-O-(tert-butyldimethylsilyl)- $\alpha$-D-erythro-hexopyranoside3-ulose.

4f - Methyl 2,6-dideoxy- $\alpha$-D-erythro-hexopyranoside-3-ulose.....................

$4 \mathrm{~g}$ - Cyclohexyl 2,6-dideoxy- $\alpha$-D-erythro-hexopyranoside-3-ulose .................

$4 \mathrm{~h}$ - 1,2,3,4-di-O-isopropylidene-6-O-(2,6-dideoxy- $\alpha$-D-erythro-hexopyranoside3 -ulosyl)- $\alpha$-D-galactopyranoside.

S26

S27

4i-Methyl 4,6-dideoxy- $\alpha$-D-erythro-hexopyranoside-3-ulose .....................

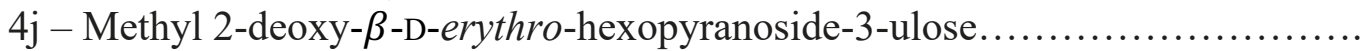

$4 \mathrm{k}$ - Methyl 2-deoxy-6-O-trimethylacetyl- $\beta$-D-erythro-hexopyranoside-3-ulose...

Derivatizations.

$5 \mathrm{a}-$ Methyl- $\alpha$-L-digitoxose

S28

S29

$\mathrm{S} 30$

S31

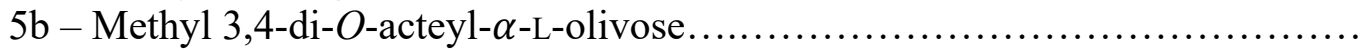

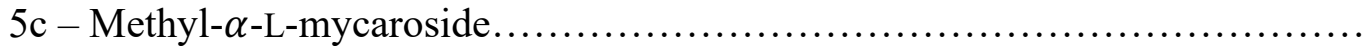

Substrate Limitations

2 - 4-tert-butylphenyl-2- $O$-benzoyl- $\alpha$-L-rhamnopyranoside

S31

S31

$\mathrm{S} 32$

20 - Phenyl 2- $O$-benzoyl-1-thio- $\alpha$-L-rhamnopyranoside.

S33

$2 \mathrm{p}$ - Methyl 3-O-benzoyl -6-O-(tert-butyldimethylsilyl)- $\alpha$-D-galactopyranoside...

2 p' - Methyl 3-O-trimethylacetyl -6-O-(tert-butyldimethylsilyl)- $\beta$-D-

galactopyranoside

S34

S35

S35

2q-Methyl 3-O-benzoyl -6-O-(tert-butyldimethylsilyl)- $\alpha$-D-mannopyranoside...

$2 \mathrm{r}$ - Methyl 2-O-trimethylacetyl-D-xylofuranoside

S36

S36

S36

Computational Data

S38

Table S4. Calculated gas-phase free energies of transition states for hydrogen atom transfer from 2-OPiv- $\alpha$-Glc to the quinuclidine radical cation...................... Table S5. Calculated free energies of transition states for hydrogen atom transfer from 2-OPiv- $\alpha$-Glc to the quinuclidine radical cation (PCM(acetonitrile))......... Table S6. Calculated gas-phase free energies of transition states for hydrogen atom transfer from 2-OPiv- $\alpha$-Glc $\bullet 4-\mathrm{ClOBz}]^{-}$to the quinuclidine radical cation... Table S7. Calculated gas-phase free energies of transition states for hydrogen atom transfer from 2-OPiv- $\beta$-Glc to the quinuclidine radical cation................ Table S8. Calculated gas-phase free energies of transition states for hydrogen atom transfer from 3-OPiv-Glc to the quinuclidine radical cation.

S38

Table S9. Calculated gas-phase free energies of transition states for hydrogen atom transfer from 2-OPiv- $\beta$-xyl to the quinuclidine radical cation. Table S10. Calculated gas-phase free energies of transition states for hydrogen atom transfer from 2-OPiv- $\beta$-xyl to the quinuclidine radical cation....

Table S11. Calculated energies of per-methylated 2-O-acylated- $\alpha$-gluco- and manno-pyranosides with a radical at C-3.

Table S12. Calculated energies of reaction intermediates in Figure S1. . .

Table S13. Calculated energies of reaction intermediates in Figure S2. 
Table S14. Calculated energies of reaction intermediates in Figure S3........... S44

References........................................................................ s129

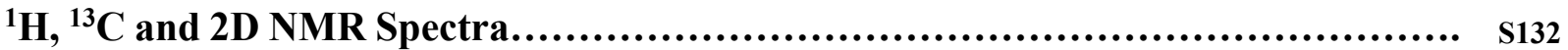

\section{General Information}

\section{Materials}

Stainless steel needles and syringes were used to transfer air and moisture sensitive liquids. Schlenk flasks and $4 \AA$ molecular sieves were stored at $140{ }^{\circ} \mathrm{C}$ for at least 24 hours before use. Acetonitrile was HPLC grade and purified using a solvent purification system equipped with columns of activated alumina under nitrogen (Innovative Technology, Inc.). Other solvents and reagents were used without further purification. Flash column chromatography was performed using neutral silica gel (60 A, 230 - 400 mesh, Silicycle). Thin-layer chromatography (TLC) was performed using aluminum backed silica gel plates (details), and compounds were visualized by UV irradiation at $254 \mathrm{~nm}$ and by staining with $\mathrm{KMnO}_{4}$ solution.

\section{Instrumentation}

Proton nuclear magnetic resonance $\left({ }^{1} \mathrm{H}\right.$ NMR) spectra and carbon nuclear magnetic resonance $\left({ }^{13} \mathrm{C}\right)$ spectra were recorded on a $400 \mathrm{MHz}$ Varian Mercury Spectrometer or a $400 \mathrm{MHz}$ Bruker Spectrometer. Chemical shifts for protons are recorded in parts per million (ppm) relative to tetramethylsilane and are referenced to residual protium in the solvent $\left(\mathrm{CDCl}_{3}: \delta 7.26\right.$, DMSO- $d_{6}$ : $\delta$ 2.50). Chemical shifts for carbons are recorded in parts per million (ppm) relative to tetramethylsilane and are referenced to residual carbon in the solvent $\left(\mathrm{CDCl}_{3}: \delta 77.16\right.$, DMSO- $d_{6}$ : $\delta$ 39.52). Data are represented in the following order: chemical shift $(\delta$, ppm); multiplicity (s, singlet; d, doublet; t, triplet; q, quartet; m, multiplet; br s, broad singlet); coupling constant (J, Hz); number of protons; assignment. Proton assignments were made based on coupling constants and 2D NMR spectra. High-resolution mass spectra (HRMS) were obtained on a JEOL AccuTOF JMS- T1000LC mass spectrometer equipped with a DART (direct analysis in real time) ion source. Infrared (IR) spectra were obtained on a Perkin-Elmer Spectrum 100 instrument equipped with a singlebounce diamond/ZnSe ATR accessory as neat samples, or as thin film from $\mathrm{CH} 2 \mathrm{Cl} 2$ as indicated. Spectral features are tabulated as follows: wavenumber (cm-1); intensity (s-strong, mmedium, w-weak). Specific rotations were measured with a Rudolph Autopol IV digital polarimeter equipped with a sodium lamp source $(589 \mathrm{~nm})$ and concentration (c) is reported in $\mathrm{g} / 100 \mathrm{~mL}$. Alkylation reactions were all run in $1 / 2$ dram or 1 dram vials and placed 5 inches from a Kessil® LED lamp (either: A160WE Tuna Blue (40 W) or H150-Blue (32 W). 


\section{Preparation of Hydrogen Bond Acceptors}

\section{General Procedure A for preparation of hydrogen bond acceptor catalysts}

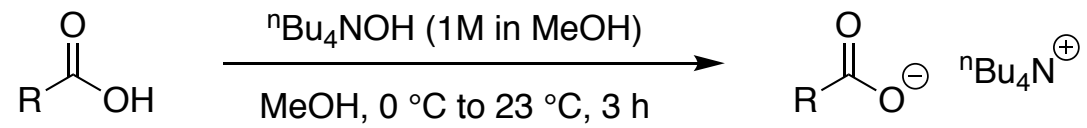

Synthesized according to adapted literature procedures. ${ }^{1}$ To an oven-dried round bottom flask equipped with a magnetic stir bar was added the carboxylic acid ( $5 \mathrm{mmol}, 1$ equiv.). A rubber septum was used to seal the flask, which was then evacuated and backfilled with argon three times under Schlenk line. Dry methanol ( $3 \mathrm{~mL}$ ) was added to the flask under a balloon of argon. Reaction cooled to $0^{\circ} \mathrm{C}$, and tetrabutylammonium hydroxide (1 M in methanol) $(5 \mathrm{~mL}, 5 \mathrm{mmol})$ was added dropwise. Reaction was warmed to room temperature and stirred for 3 hours under a balloon argon. Solvent was removed under reduced pressure and reaction mixture was transferred to a vacuum desiccator until dry.

\section{Tetrabutylammonium 4-chlorobenzoate}

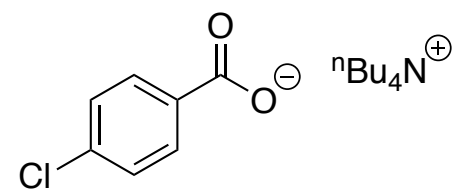

Prepared according to General Procedure A using 4-chlorobenzoic acid (782.8 mg, $5.00 \mathrm{mmol}, 1$ equiv.). The product was isolated as a white solid in quantitative yield. NMR data were consistent with previous literature reports. ${ }^{1}$

${ }^{1}$ H NMR (400 MHz, CDCl $): \delta(p p m)=8.03(\mathrm{~d}, J=8.6 \mathrm{~Hz}, 2 \mathrm{H}), 7.24(\mathrm{~d}, J=8.6 \mathrm{~Hz}, 2 \mathrm{H}), 3.41-$ $3.34(\mathrm{~m}, 8 \mathrm{H}), 1.70-1.59(\mathrm{~m}, 8 \mathrm{H}), 1.47-1.36(\mathrm{~m}, 8 \mathrm{H}), 0.97(\mathrm{t}, J=7.3 \mathrm{~Hz}, 12 \mathrm{H})$.

\section{Tetrabutylammonium trimethylacetate}<smiles>CCCCCCCC(C)(C)C(=O)O[Na]</smiles>

Prepared according to General Procedure A using trimethylacetic acid (510.0 mg, $5.00 \mathrm{mmol}, 1$ equiv.). The product was isolated as a pale-yellow oil in quantitative yield.

Spectral data were in agreement with those previously reported. ${ }^{2}$

${ }^{1}$ H NMR (400 MHz, $\left.\mathbf{C D C l}_{3}\right): \delta(\mathrm{ppm})=3.27-3.20\left(\mathrm{~m}, 8 \mathrm{H},-\mathrm{CH}_{2}\right), 1.64-1.54\left(\mathrm{~m}, 8 \mathrm{H},-\mathrm{CH}_{2}\right), 1.38-$ $1.27\left(\mathrm{~m}, 8 \mathrm{H},-\mathrm{CH}_{2}\right), 0.97\left(\mathrm{~s}, 9 \mathrm{H},-\mathrm{C}\left(\mathrm{CH}_{3}\right)\right), 0.93\left(\mathrm{t}, J=7.3 \mathrm{~Hz}, 12 \mathrm{H},-\mathrm{CH}_{3}\right)$. 
Tetrabutylammonium 2,3,4,5-tetrafluorobenzoate

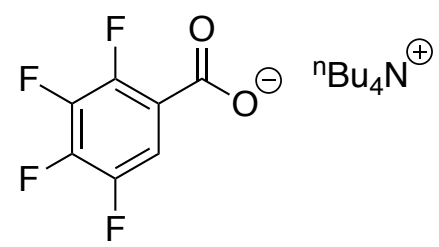

Prepared according to General Procedure A using 2,3,4,5-tetrafluorobenzoic acid (5.00 mmol, 1 equiv.). The product was isolated as a white solid in quantitative yield.

${ }^{1}$ H NMR (400 MHz, $\left.\mathbf{C D C l}_{3}\right): \delta(\mathrm{ppm})=7.48-7.41(\mathrm{~m}, 1 \mathrm{H}, \mathrm{Ar}-\mathrm{H}), 3.37-3.33\left(\mathrm{~m}, 8 \mathrm{H},-\mathrm{CH}_{2}\right)$, $1.70-1.62\left(\mathrm{~m}, 8 \mathrm{H},-\mathrm{CH}_{2}\right), 1.46-1.37\left(\mathrm{~m}, 8 \mathrm{H},-\mathrm{CH}_{2}\right), 0.97\left(\mathrm{t}, J=7.3 \mathrm{~Hz}, 12 \mathrm{H},-\mathrm{CH}_{3}\right)$

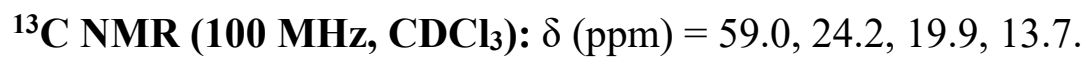

\section{Tetrabutylammonium 3,4,5-trifluorobenzoate}

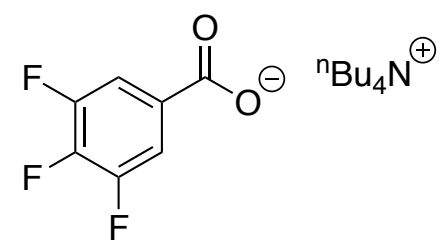

Prepared according to General Procedure A using 3,4,5-triflurobenzoic acid (5.00 mmol, 1 equiv.). The product was isolated at as white solid in quantitative yield.

${ }^{1}$ H NMR (400 MHz, CDCl $): \delta(\mathrm{ppm})=7.74-7.67(\mathrm{~m}, 2 \mathrm{H}, \mathrm{Ar}-\mathrm{H}), 3.37-3.33\left(\mathrm{~m}, 8 \mathrm{H},-\mathrm{CH}_{2}\right)$, 1.69-1.61 (m, 8H, $\left.-\mathrm{CH}_{2}\right), 1.47-1.37\left(\mathrm{~m}, 8 \mathrm{H},-\mathrm{CH}_{2}\right), 0.98\left(\mathrm{t}, J=7.3 \mathrm{~Hz}, 12 \mathrm{H},-\mathrm{CH}_{3}\right)$

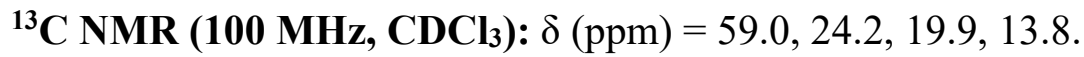

\section{Sodium dibutylphosphate}<smiles>O=P([O-])(O[Na])O[GaH2]</smiles>

Synthesized according to previous literature procedures. ${ }^{3}$

Spectral data were in agreement with those previously reported. ${ }^{3}$ 
${ }^{1}$ H NMR (500 MHz, CDCl$): ~ \delta(p p m)=3.79(q, J=6.5 \mathrm{~Hz}, 2 \mathrm{H}), 1.59(\mathrm{dq}, \mathrm{J}=12.4,7.0 \mathrm{~Hz}, 2 \mathrm{H})$, $1.44-1.30(\mathrm{~m}, 2 \mathrm{H}), 0.94(\mathrm{t}, \mathrm{J}=7.3 \mathrm{~Hz}, 3 \mathrm{H})$

${ }^{13} \mathbf{C}$ NMR (125 MHz, $\left.\mathbf{C D C l}_{3}\right): \delta(\mathrm{ppm})=33.0,32.9,19.1,13.9$

${ }^{31}$ P NMR (121 MHz, $\left.\mathbf{C D C l}_{3}\right): \delta(\mathrm{ppm})=1.50$

\section{Tetrabutylammonium dibutylphosphate}

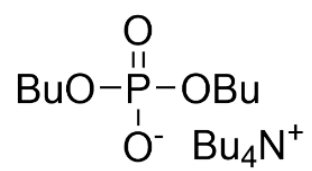

Prepared according to General Procedure A using dibutylphosphate (5.00 mmol, 1 equiv.). The product was isolated as a clear liquid in quantitative yield and stored under vacuum.

Spectral data were in agreement with those previously reported. ${ }^{4}$

${ }^{1} \mathrm{H}_{\text {NMR }}\left(\mathbf{4 0 0} \mathrm{MHz}, \mathbf{C D C l}_{3}\right): \delta(\mathrm{ppm})=3.85-3.80(\mathrm{~m}, 4.2 \mathrm{H}), 3.42-3.35(\mathrm{~m}, 8 \mathrm{H}), 1.70-1.60(\mathrm{~m}$, $12.4 \mathrm{H}), 1.49-1.35$ (m, 12.4 H), 0.99 (t, J=7.4 Hz, 12H), 0.89 (t, J = 7.4 Hz, 6.5H)

\section{Tetrabutylammonium diphenylphosphate}<smiles>O=P([O-])(Oc1ccccc1)c1ccccc1</smiles>

Prepared according to General Procedure A using dibutylphosphate (5.00 mmol, 1 equiv.). The product was isolated as a white solid in quantitative yield and stored under vacuum.

${ }^{1} \mathbf{H}$ NMR (500 MHz, $\left.\mathbf{C D C l}_{3}\right): \delta(\mathrm{ppm})=7.28=7.17(\mathrm{~m}, 4 \mathrm{H}), 7.05(\mathrm{~m}, 1 \mathrm{H}), 3.21-3.12(\mathrm{~m}, 2 \mathrm{H})$, 1.54 (p, J=8.1, 7.6 Hz, 2H), 1.32 (h, J=7.3 Hz, 2H), 0.90 (t, J=7.3 Hz, 3H)

${ }^{13}$ C NMR (125 MHz, $\left.\mathbf{C D C l}_{3}\right): \delta(\mathrm{ppm})=152.3,152.2,129.2,123.6$ (2C), 120.4 (2C), 58.63, 23.8, $19.6,13.6$

${ }^{31} \mathbf{P}$ NMR (121 MHz, $\left.\mathbf{C D C l}_{3}\right): \delta(\mathrm{ppm})=-12.9$ 


\section{Preparation of Substrates}

\section{General Procedure B for monoacylation of carbohydrates}

Monoacylation was adapted from previous literature procedures. ${ }^{5}$

Methyl- $\alpha$-L-rhamnopyranoside ( 1 equiv.) and phenyl boronic acid (1 equiv.) were dissolved in toluene $(5 \mathrm{~mL} / \mathrm{mmol})$ and heated at $110{ }^{\circ} \mathrm{C}$ for $13 \mathrm{~h}$. Toluene was removed under reduced pressure and the resulting residue was azeotroped with toluene three times. The boronic ester was dissolved in pyridine $(2 \mathrm{~mL} / \mathrm{mmol})$ and cooled to $0{ }^{\circ} \mathrm{C}$ with stirring. Trimethyl acetyl chloride (2 equiv.) was added and the reaction was warmed to $23{ }^{\circ} \mathrm{C}$ and allowed to stir until TLC revealed full consumption of the starting material (ca. $13 \mathrm{~h}$ ). Reaction was dilute with toluene and filtered through a pad of Celite ${ }^{\circledR}$ followed by removal of the solvent under vacuum. The resulting residue was dissolved in ethyl acetate, added to a solution of $1.0 \mathrm{M}$ sorbitol: $1 \mathrm{M}$ sodium carbonate aqueous solution and shaken for five minutes. The aqueous phase was extracted with ethyl acetate several times. The combined organic layers were dried over $\mathrm{MgSO}_{4}$, filtered and concentrated under vacuum.

\section{General Procedure $\mathbf{C}$ for monoacylation of carbohydrates}

Monoacylation was adapted from previous literature procedures. ${ }^{6}$

To round bottom flask equipped with a magnetic stir bar was added the pyranoside derivative (1.00 mmol, 1 equiv.) and copper (II) trifluoroacetic acid (1.30 mmol, 1.3 equiv.), and dissolved in acetonitrile $(8 \mathrm{~mL})$. The anhydride $(1.30 \mathrm{mmol}, 1.3$ equiv.) was added then 2,4,6-collidine (1.30 mmol, 1.3 equiv.) was added dropwise. The reaction was allowed to stir at $25^{\circ} \mathrm{C}$ for 6 hours. The reaction was diluted with dichloromethane and washed with $1 \mathrm{M}$ hydrochloric acid, saturated sodium bicarbonate, then water. The organic layer was dried over $\mathrm{MgSO}_{4}$ and concentrated under reduced pressure. The crude material was then purified by flash column chromatography on silica gel. 
2a - Methyl 2-O-trimethylacetyl- $\alpha$-D-glucopyranoside

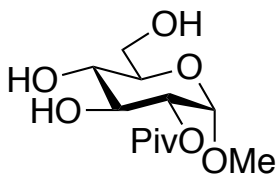

Prepared according to previous literature procedures from methyl $\alpha$-D-glucopyranoside and trimethylacetyl chloride. ${ }^{5}$

Spectral data were in agreement with those previously reported. ${ }^{5}$

${ }^{1}$ H NMR (400 MHz, CDCl 3 ): $\delta(\mathrm{ppm})=4.90(\mathrm{~d}, J=3.7 \mathrm{~Hz}, 1 \mathrm{H}, \mathrm{H}-1), 4.60(\mathrm{dd}, J=10.0,3.7 \mathrm{~Hz}$, 1H, H-2), 4.03-3.95 (m, 1H, H-3), 3.90-3.83 (m, 2H, H-6, H-6), 3.71-3.62 (m, 2H, H-4, H-5), $3.37\left(\mathrm{~s}, 3 \mathrm{H},-\mathrm{OCH}_{3}\right), 1.24\left(\mathrm{~s}, 9 \mathrm{H},\left(\mathrm{CH}_{3}\right)_{3} \mathrm{CCO}\right)$.

\section{3a - Methyl 2-O-benzoyl- $\alpha$-D-glucopyranoside}

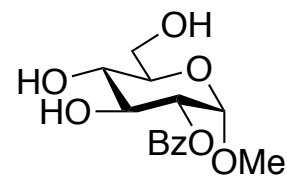

Prepared according to a modified literature procedure from methyl $\alpha$-D-glucopyranoside and benzoyl chloride using dibutyltin chloride. ${ }^{7}$

Spectral data were in agreement with those previous reported. ${ }^{7}$

${ }^{1}$ H NMR (400 MHz, CDCl $): \delta(p p m)=8.09(\mathrm{~d}, J=6.9 \mathrm{~Hz}, 2 \mathrm{H}), 7.60(\mathrm{t}, J=7.5 \mathrm{~Hz}, 1 \mathrm{H}), 7.47(\mathrm{t}$, $J=7.5 \mathrm{~Hz}, 2 \mathrm{H}), 5.04(\mathrm{~d}, J=3.6 \mathrm{~Hz}, 1 \mathrm{H}), 4.91(\mathrm{dd}, J=3.6,9.9 \mathrm{~Hz}, 1 \mathrm{H}), 4.16(\mathrm{t}, J=3.6 \mathrm{~Hz}, 1 \mathrm{H})$, 3.92-3.89 (m, 2H), 3.75-3.72 (m, 2H), 3.40 (s, 3H), 2.62 (br s, 1H), 2.50 (br s, 1H), 2.00 (br s, 1H).

\section{3b - Methyl 2-O-(tert-butyloxycarbonyl) $\alpha$-D-glucopyranoside}<smiles>COC(OC(=O)OC(C)(C)C)C1(CO)C(O)COC1CO</smiles>

Prepared according to General Procedure B from methyl $\alpha$-D-glucopyranoside and di-tert-butyl decarbonate with the following changes: di-tert-butyl decarbonate was used as the acylating agent in place of trimethylacetyl chloride, and DMAP (10 mol\%) was added. Product $\mathbf{3 b}$ was obtained as an off-white solid (30\%) after flash column chromatography on silica (20\% to $50 \%$ acetone in DCM). 
$\mathbf{R}_{\mathbf{f}}=0.22$ (Acetone:DCM 1:1)

${ }^{1}$ H NMR (500 MHz, CDCl $): \delta(\mathrm{ppm})=4.95(\mathrm{~d}, J=3.6 \mathrm{~Hz}, 1 \mathrm{H}), 4.47(\mathrm{dd}, J=10.0,3.6 \mathrm{~Hz}, 1 \mathrm{H})$, $3.96(\mathrm{t}, J=8.8 \mathrm{~Hz}, 1 \mathrm{H}), 3.86(\mathrm{~s}, 2 \mathrm{H}), 3.69-3.59(\mathrm{~m}, 2 \mathrm{H}), 3.58(\mathrm{~s}, 1 \mathrm{H}), 3.39(\mathrm{~s}, 3 \mathrm{H}), 3.31(\mathrm{~s}, 1 \mathrm{H})$, $1.49(\mathrm{~s}, 9 \mathrm{H})$.

${ }^{13} \mathbf{C}$ NMR (125 MHz, $\left.\mathbf{C D C l}_{3}\right): \delta(\mathrm{ppm})=153.2,97.1,83.2,75.7,71.7,70.8,70.5,61.9,55.3,27.7$

IR (neat, cm-1): 3422 (w), 2989 (w), 2940 (w), 1739 (s), 1278 (s), 1154 (s), 1038 (s), 820 (s)

HRMS (DART ${ }^{+}, \mathrm{m} / \mathrm{z}$ ): calculated for $\mathrm{C}_{12} \mathrm{H}_{24} \mathrm{O}_{8}\left[\mathrm{M}+\mathrm{NH}_{4}\right]^{+}: 312.16584$; found: 312.16529

$[\boldsymbol{\alpha}]_{\mathbf{D}}^{\mathbf{2 0}}=+32.0\left(\mathrm{c}=13.3 \mathrm{mg} / \mathrm{mL}, \mathrm{CHCl}_{3}\right)$

\section{3c - Methyl 2-O-tosyl- $\alpha$-D-glucopyranoside}

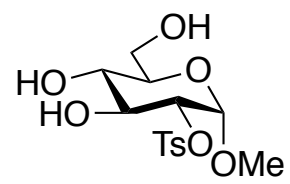

Prepared according to a modified literature procedure from methyl $\alpha$-D-glucopyranoside and tosyl chloride using dibutyltin chloride. ${ }^{7}$

Methyl $\alpha$-D-glucopyranoside ( $1 \mathrm{mmol}, 1$ equiv. $), \mathrm{Bu}_{2} \mathrm{SnCl}_{2}$ (0.05 mmol, 0.05 equiv.), and DIPEA ( 2 mmol, 2 equiv.) were added to a round bottom flask equipped with a magnetic stir bar and dissolved in THF (4 mL). 4-toluenesulfonyl chloride (1.1 mmol, 1.1 equiv.) was added and the reaction was stirred at $23{ }^{\circ} \mathrm{C}$ for 2.5 hours. $3 \%$ aqueous hydrochloric acid solution $(40 \mathrm{~mL})$ was added to the reaction and extracted with ethyl acetate $(3 \times 40 \mathrm{~mL})$. Combined organic layers were dried over $\mathrm{MgSO}_{4}$, filtered, and concentrated under reduced pressure. Crude material was purified by flash column chromatography on silica (10\% methanol in dichloromethane) to afford the product as a clear solid (50 mg, 14\%).

Spectral data agreed with those previously reported. ${ }^{8}$

${ }^{1}$ H NMR (400 MHz, CDCl 3$): ~ \delta(p p m)=7.84(\mathrm{~d}, J=8.3 \mathrm{~Hz}, 1 \mathrm{H}), 7.34(\mathrm{~d}, J=8.1 \mathrm{~Hz}, 1 \mathrm{H}), 4.65$ $(\mathrm{d}, J=3.7 \mathrm{~Hz}, 1 \mathrm{H}), 4.36(\mathrm{dd}, J=9.7,3.7 \mathrm{~Hz}, 1 \mathrm{H}), 4.14$ (br s, 1H), 3.96-3.87 (m, 1H), 3.81 (dd, $J$ $=13.9,2.9 \mathrm{~Hz}, 1 \mathrm{H}), 3.66-3.51(\mathrm{~m}, 1 \mathrm{H}), 3.25(\mathrm{~s}, 1 \mathrm{H}), 2.94(\mathrm{br} \mathrm{s}, 1 \mathrm{H}), 2.43(\mathrm{~s}, 3 \mathrm{H})$

\section{2b - Methyl 2-O-trimethylacetyl-6-O-(tert-butyldimethylsilyl)- $\alpha$-D-glucopyranoside}

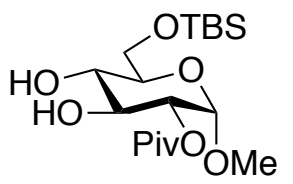


Prepared according to adapted literature procedures. ${ }^{9}$

Methyl 2-O-trimethylacetyl- $\alpha$-D-glucopyranoside (278.2 $\mathrm{mg}, 1 \mathrm{mmol}, 1$ equiv.) and tertbityldimethylsilyl chloride ( $180.9 \mathrm{mg}, 1.2 \mathrm{mmol}, 1.2$ equiv.) were dissolved in pyridine $(0.7 \mathrm{M})$ and stirred at $23{ }^{\circ} \mathrm{C}$ for 13 hours. Reaction mixture was diluted with dichloromethane and washed with water, then aqueous layer was extracted several times with dichloromethane. The organic layers were combined, dried over $\mathrm{MgSO}_{4}$, filtered, and concentrated under vacuum. The resulting residue was purified by flash column chromatography on silica (30\% to $50 \%$ ethyl acetate in hexanes) to afford $\mathbf{2 b}$ as a white solid $(311.3 \mathrm{mg}, 79 \%)$.

Spectral data were in agreement with those previously reported. ${ }^{10}$

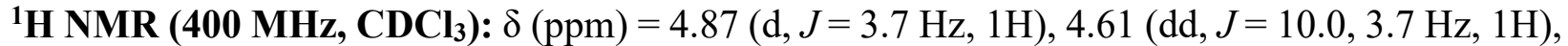
4.03-3.96 (m, 1H), $3.90(\mathrm{dd}, J=10.5,4.6 \mathrm{~Hz}, 1 \mathrm{H}), 3.82(\mathrm{dd}, 10.5,5.0 \mathrm{~Hz}, 1 \mathrm{H}), 3.63(\mathrm{~m}, 2 \mathrm{H}), 3.36$ $(\mathrm{s}, 3 \mathrm{H}), 1.24(\mathrm{~s}, 9 \mathrm{H}), 0.91(\mathrm{~s}, 9 \mathrm{H}), 0.10(\mathrm{~s}, 3 \mathrm{H}), 0.10(\mathrm{~s}, 3 \mathrm{H})$.

\section{2c - Methyl 2,6-di- $O$-trimethylacetyl- $\alpha$-D-glucopyranoside}

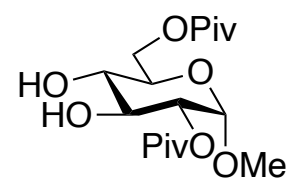

Prepared according to previous literature procedures. ${ }^{11}$

Spectral data were in agreement with those previously reported. ${ }^{11}$

${ }^{1}$ H NMR (400 MHz, CDCl 3 ): $\delta(\mathrm{ppm})=4.89(\mathrm{~d}, J=3.7 \mathrm{~Hz}, 1 \mathrm{H}), 4.60(\mathrm{dd}, J=10.0,3.7 \mathrm{~Hz}, 1 \mathrm{H})$, 4.50 (dd, $J=12.2,4.5 \mathrm{~Hz}, 1 \mathrm{H}), 4.26(\mathrm{dd}, J=12.2,2.2 \mathrm{~Hz}, 1 \mathrm{H}), 3.98$ (dd, $J=9.4,9.4 \mathrm{~Hz}, 1 \mathrm{H})$, $3.79-3.74(\mathrm{~m}, 1 \mathrm{H}), 3.37(\mathrm{~s}, 3 \mathrm{H}), 3.35(\mathrm{dd}, J=9.5,9.5 \mathrm{~Hz}, 1 \mathrm{H}), 1.23(\mathrm{~s}, 18 \mathrm{H})$.

\section{2d - Methyl 2-O-Trimethylacetyl-6-O-(2',3',4',6'-tetra-O-acetyl- $\beta$-D-galactopyranosyl)- $\alpha$-D- glucopyranoside}

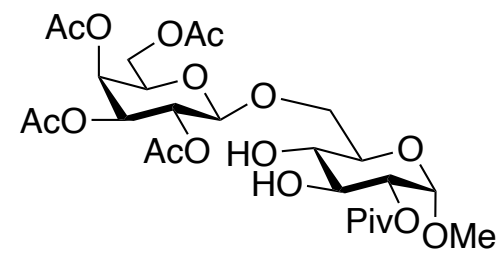

Synthesized according to adapted literature procedures. ${ }^{12}$

Methyl- $\alpha$-D-glucopyranoside (485.4 $\mathrm{mg}, \quad 2.5 \quad \mathrm{mmol}, \quad 1 \quad$ equiv.) and 4(trifluoromethyl)phenylboronic acid (474.8 mg, $2.5 \mathrm{mmol}, 1$ equiv.) were dissolved in toluene (12 $\mathrm{mL})$ and stirred at $110^{\circ} \mathrm{C}$ overnight. After reaction solvent was removed under vacuum and the 
crude residue was azeotroped with toluene three times. The crude boronic ester was dissolved in anhydrous pyridine $(5 \mathrm{~mL})$ and cooled to $0{ }^{\circ} \mathrm{C}$ with stirring. Trimethylacetyl chloride $(0.37 \mathrm{~mL}, 3$ mmol, 1.2 equiv.) was added then the reaction was warmed to $23{ }^{\circ} \mathrm{C}$ and stirred for 30 minutes.

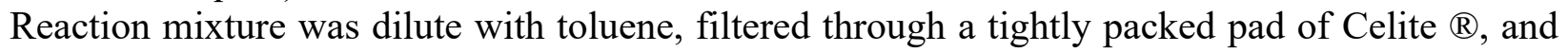
concentrated under vacuum. Crude material was dissolved in dry dichloromethane $(12.5 \mathrm{~mL})$ and transferred to an oven dried flask equipped with a magnetic stir bar and $4 \AA$ molecular sieves under argon. 2,3,4,6-tetra- $O$-acteyl- $\alpha$-D-galactosyl bromide (1.54 g, $3.75 \mathrm{mmol}, 1.5$ equiv.), silver(I) oxide (868.9 mg, $3.75 \mathrm{mmol}, 1.5$ equiv.), and triethylamine (2.1 mL, $15 \mathrm{mmol}, 6$ equiv.) were added under argon and the mixture was stirred vigorously $(>800 \mathrm{rpm})$ overnight. Reaction was quenched with methanol, filtered through a tightly packed pad of Celite ${ }^{\circledR}$, and concentrated under vacuum. The crude residue was purified by flash column chromatography on silica (10\% to $40 \%$ acetone in dichloromethane) to afford (2d) as a white solid (710 mg, 47\%).

$\mathbf{R}_{\mathbf{f}}=0.29(20 \%$ acetone in dichloromethane)

${ }^{1}$ H NMR (500 MHz, $\left.\mathbf{C D C l}_{3}\right): \delta(\mathrm{ppm})=5.39(\mathrm{dd}, J=3.4,1.2 \mathrm{~Hz}, 1 \mathrm{H}, \mathrm{H}-4$ ') 5.25 (dd, $J=10.5$, $8.1 \mathrm{~Hz}, 1 \mathrm{H}, \mathrm{H}-2^{\prime}$ ), 5.03 (dd, $J=10.4,3.4 \mathrm{~Hz}, 1 \mathrm{H}, \mathrm{H}-3$ '), 4.87 (d, $\left.J=3.7 \mathrm{~Hz} 1 \mathrm{H}, \mathrm{H}-1\right), 4.60$ (dd, $J$ $=9.9,3.7 \mathrm{~Hz}, 1 \mathrm{H}, \mathrm{H}-2), 4.58$ (d, $J=8.0 \mathrm{~Hz}, 1 \mathrm{H}, \mathrm{H}-1^{\prime}$ ), 4.20 (dd, $J=11.2,6.6 \mathrm{~Hz}, 1 \mathrm{H}, \mathrm{H}-6$ '), 4.154.10 (m, 2H, H-6, H-6'), 3.97-3.92 (m, 2H, H-3), 3.80 (dd, J=10.6, 5.4 Hz, 1H, H-6), 3.77-3.73 (m, 1H, H-5, H-5'), 3.52 (apt t, $J=9.3 \mathrm{~Hz}, 1 \mathrm{H}, \mathrm{H}-4), 3.35$ (s, 3H, -OCH $), 2.75$ (br s, 1H, -OH), 2.45 (br s, 1H, - OH), 2.15 (s, 3H, - $\mathrm{CO}\left(\mathrm{CH}_{3}\right), 2.06$ (s, 3H, $-\mathrm{CO}\left(\mathrm{CH}_{3}\right), 2.06$ (s, 3H, - $\mathrm{CO}\left(\mathrm{CH}_{3}\right), 1.99$ $\left(\mathrm{s}, 3 \mathrm{H},-\mathrm{CO}\left(\mathrm{CH}_{3}\right), 1.23\left(\mathrm{~s}, 9 \mathrm{H},-\mathrm{C}\left(\mathrm{CH}_{3}\right)_{3}\right)\right.$.

${ }^{13}$ C NMR (125 MHz, CDCl $): \delta(\mathrm{ppm})=178.6,170.7,170.4,170.3,169.8,101.6,97.2,73.3$, 71.9, 71.5, 71.1, 70.9, 69.7, 69.0, 68.8, 67.2, 61.5, 55.6, 39.0, 27.2, 20.9, 20.8, 20.8, 20.7.

IR (neat, cm-1): 3474 (w), 2945 (w), 1737 (s), 1369 (s), 1220 (s), 1158 (s), 1037 (s), 910 (s).

HRMS (DART ${ }^{+}, \mathrm{m} / \mathrm{z}$ ): calculated for $\mathrm{C}_{26} \mathrm{H}_{44} \mathrm{NO}_{16}\left[\mathrm{M}+\mathrm{NH}_{4}\right]^{+}:$: 626.26546, found: 626.26517.

\section{2e - Methyl 2-O-trimethylacetyl-6-O-(tert-butyldimethylsilyl)- $\alpha$-D-galactopyranoside}

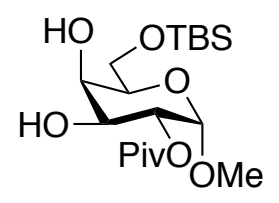

Synthesized according to General Procedure B from methyl 6-O-(tert-butyldimethylsilyl)- $\alpha$-Dgalactopyranoside. The crude material was purified by flash column chromatography on silica (20\% to $50 \%$ ethyl acetate in hexanes to afford $2 \mathbf{e}$ as a white solid $(30 \%)$.

$\boldsymbol{R}_{\mathbf{f}}=0.42(30 \%$ ethyl acetate in hexanes)

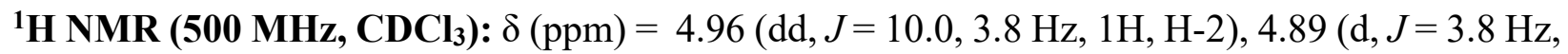
1H, H-1), 4.13-4.12 (m, 1H, H-5), 3.99-3.87 (m, 3H, H-3, H-6a, H-6b), 3.78 (dd, J = 5.1, 5.1 Hz, 
$1 \mathrm{H}, \mathrm{H}-4), 3.36\left(\mathrm{~s}, 3 \mathrm{H},-\mathrm{OCH}_{3}\right), 3.25(\mathrm{~d}, J=2.8 \mathrm{~Hz}, 1 \mathrm{H},-\mathrm{OH}), 2.50(\mathrm{~d}, J=7.9 \mathrm{~Hz}, 1 \mathrm{H},-\mathrm{OH}), 1.24$ $\left(\mathrm{s}, 9 \mathrm{H},-\mathrm{C}\left(\mathrm{CH}_{3}\right)_{3}\right), 0.90\left(\mathrm{~s}, 3 \mathrm{H},-\mathrm{C}\left(\mathrm{CH}_{3}\right)_{3}\right), 0.10\left(\mathrm{~s}, 3 \mathrm{H},-\mathrm{Si}\left(\mathrm{CH}_{3}\right)_{2}\right), 0.10\left(\mathrm{~s}, 3 \mathrm{H},-\mathrm{Si}\left(\mathrm{CH}_{3}\right)_{2}\right)$.

${ }^{13} \mathbf{C}$ NMR (126 MHz, $\left.\mathbf{C D C l}_{3}\right): \delta(\mathrm{ppm})=179.1,97.7,71.9,70.5,69.1,68.9,63.7,55.6,39.1,27.2$, $26.0,18.4,-5.3$.

IR (neat, cm-1 ): 3519 (w), 2930 (w), 2856 (w), 1711 (s), 1358 (s), 1294 (s), 1254 (s), 1182 (s), 1143 (s), 1084 (s), 1031 (s), 837 (s), 775 (s), 695 (s).

HRMS (DART ${ }^{+}, \mathrm{m} / \mathrm{z}$ ): calculated for $\mathrm{C}_{18} \mathrm{H}_{37} \mathrm{O}_{7} \mathrm{Si}[\mathrm{M}+\mathrm{H}]^{+}:$: 393.23031; found: 393.23113 .

\section{2f - Methyl 2-O-benzoyl-6-O-(tert-butyldimethylsilyl)- $\alpha$-D-mannopyranoside}

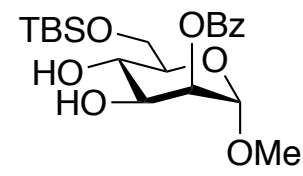

Prepared according to General Procedure $\mathrm{C}$ from methyl 6-O-(tert-butyldimethylsilyl)- $\alpha$-Dmannopyranoside and benzoic anhydride. Product $\mathbf{2 f}$ was isolated as a white solid (58\%) after flash column chromatography on silica (30\% to $50 \%$ ethyl acetate in hexanes).

Spectral data were in agreement with those previously reported. ${ }^{13}$

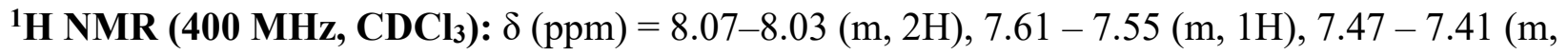
$2 \mathrm{H}), 5.33(\mathrm{dd}, J=3.4,1.7 \mathrm{~Hz}, 1 \mathrm{H}), 4.82(\mathrm{~d}, J=1.5 \mathrm{~Hz}, 1 \mathrm{H}), 4.12(\mathrm{dd}, J=9.5,3.5 \mathrm{~Hz}, 1 \mathrm{H}), 4.00$ $(\mathrm{t}, J=9.4 \mathrm{~Hz}, 1 \mathrm{H}), 3.98(\mathrm{dd}, J=5.6,4.6 \mathrm{~Hz}, 1 \mathrm{H}), 3.89(\mathrm{dd}, J=10.6,5.2 \mathrm{~Hz}, 1 \mathrm{H}), 3.66(\mathrm{dt}, J=9.4$, $4.7 \mathrm{~Hz}, 1 \mathrm{H}), 3.40$ (s, 3H), $0.93(\mathrm{~s}, 9 \mathrm{H}), 0.12(\mathrm{~s}, 6 \mathrm{H})$.

\section{2g - Methyl 4-O-trimethylacetyl-6-O-(tert-butyldimethylsilyl)- $\alpha$-D-mannopyranoside}

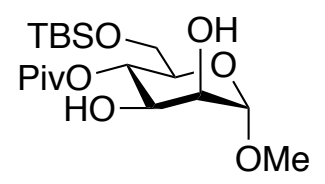

Synthesized according to General Procedure B from methyl 6-O-(tert-butyldimethylsilyl)- $\alpha$-Dmannopyranoside.

The crude material was purified by flash column chromatography on silica $(30 \%$ to $50 \%$ ethyl acetate in hexanes to afford $\mathbf{2 g}$ as a yellow solid (78\%).

$\boldsymbol{R}_{\mathbf{f}}=0.47(40 \%$ ethyl acetate in hexanes) 


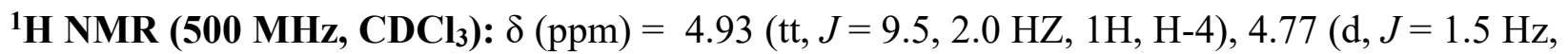
1H, H-1), 3.92-8.85 (m, 2H, H-2, H-3), 3.7-3.67 (m, 3H, H-5, H-6a, H-6b), 3.39 (s, 3H, -OCH $)$, $1.22\left(\mathrm{~s}, 9 \mathrm{H},-\mathrm{C}\left(\mathrm{CH}_{3}\right)_{3}\right), 0.88\left(\mathrm{~s}, 9 \mathrm{H},-\mathrm{C}\left(\mathrm{CH}_{3}\right)_{3}\right), 0.06\left(\mathrm{~s}, 3 \mathrm{H},-\mathrm{Si}\left(\mathrm{CH}_{3}\right)_{2}\right), 0.05\left(\mathrm{~s}, 3 \mathrm{H},-\mathrm{Si}\left(\mathrm{CH}_{3}\right)_{2}\right)$.

${ }^{13} \mathbf{C}$ NMR (126 MHz, $\left.\mathbf{C D C l}_{3}\right): \delta(\mathrm{ppm})=179.8,100.4,71.0,70.8,70.8,70.6,62.6,55.1,39.1$, $27.2,26.0,18.4,-5.2,-5.2$.

IR (neat, cm-1 ): 3444 (w), 2934 (w), 1731 (s), 1249 (s), 1150 (s), 1110 (s), 1038 (s), 972 (s), 836 (s), $776(\mathrm{~s}), 569$ (s).

HRMS (DART ${ }^{+}, \mathrm{m} / \mathrm{z}$ ): calculated for $\mathrm{C}_{18} \mathrm{H}_{37} \mathrm{O}_{7} \mathrm{Si}[\mathrm{M}+\mathrm{H}]^{+}:$393.23031; found: 393.23089

$[\alpha]_{D}^{20}=+63.6\left(\mathrm{c}=8.75 \mathrm{mg} / \mathrm{mL}, \mathrm{CHCl}_{3}\right)$

2h - Methyl 2-O-benzoyl- $\alpha$-L-rhamnopyranoside

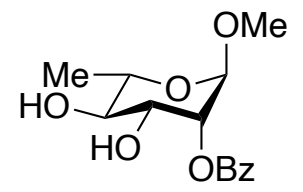

Prepared according to previous literature procedures. ${ }^{6}$

Spectral data were in agreement with those previously reported. ${ }^{6}$

${ }^{1}$ H NMR (400 MHz, $\left.\mathbf{C D C l}_{3}\right): \delta(\mathrm{ppm})=8.06-8.01(\mathrm{~m}, 2 \mathrm{H}, \mathrm{Ar}-\mathrm{H}), 7.61-7.55(\mathrm{~m}, 1 \mathrm{H}, \mathrm{Ar}-\mathrm{H})$, 7.47-7.41 (m, 2H, Ar-H), 5.32 (dd, $J=3.5,1.6 \mathrm{~Hz}, 1 \mathrm{H}, \mathrm{H}-2), 4.76$ (d, $J=1.5 \mathrm{~Hz}, 1 \mathrm{H}, \mathrm{H}-1), 4.04$ $(\mathrm{dd}, J=9.4,3.5 \mathrm{~Hz}, 1 \mathrm{H}, \mathrm{H}-3), 3.73(\mathrm{dd}, J=9.3,6.2 \mathrm{~Hz}, 1 \mathrm{H}, \mathrm{H}-5), 3.60$ (app t, $J=9.4 \mathrm{~Hz}, 1 \mathrm{H}, \mathrm{H}-$ 4), $3.39\left(\mathrm{~s}, 3 \mathrm{H},-\mathrm{OCH}_{3}\right), 1.37\left(\mathrm{~d}, 3 \mathrm{H},-\mathrm{CH}_{3}\right)$.

2i - Cyclohexyl 2-O-benzoyl- $\alpha$-L-rhamnopyranoside<smiles>[M]C1OC(O)C(O)C(O)C1OC(C)(C)C</smiles>

Prepared according to adapted literature procedure. ${ }^{14}$

To an oven-dried Schlenk flask was added $2.0 \mathrm{~g}$ of $4 \AA$ sieves and a magnetic stir bar. The flask was sealed with a rubber septum, evacuated and the sieves were activated using a heat gun. After 30 minutes, the flask was filled with argon and a solution of 2,3,4-tri-O-benzoyl- $\alpha$-Lrhamnopyranosyl bromide ( $4 \mathrm{mmol}, 1$ equiv.) and cyclohexanol (4 mmol, 1 equiv.) in $35 \mathrm{~mL}$ of a 1:1 mixture of dichloromethane and toluene was added to the flask. The reaction mixture for stirred 
for 10 minutes and then cooled to $-20^{\circ} \mathrm{C}$. A solution of silver trifluoromethanesulfonate $(4 \mathrm{mmol}$, 1 equiv.) in $15 \mathrm{~mL}$ of a 1:1 mixture of dichloromethane and toluene was added to the flask dropwise. The reaction mixture was then stirred at $-20^{\circ} \mathrm{C}$. After 2 hours, the reaction was quenched by addition of $5 \mathrm{~mL}$ of pyridine, diluted with dichloromethane and filtered through a pad of celite. The solution was then washed with a 1:1 mixture of sat. aq. $\mathrm{NaHCO}_{3}$ and $1 \mathrm{M} \mathrm{Na}_{2} \mathrm{~S}_{2} \mathrm{O}_{3}$ and $\mathrm{H}_{2} \mathrm{O}$ afterwards. The organic phase was then dried over $\mathrm{MgSO}_{4}$, filtered, and concentrated under reduced pressure. The crude material was then purified by flash chromatography (10 to $30 \%$ ethyl acetate in hexane). The product was transferred to an oven-dried, round-bottom flask, along with $\mathrm{NaOMe}(0.5$ equiv. $)$ and a magnetic stir bar. The flask was then evacuated and backfilled with argon three times on a Schlenk line. Under a balloon of argon, methanol ([sugar $]=0.2 \mathrm{M})$ was added and the mixture was stirred at room temperature. After 18 hours, the reaction was quenched with $\mathrm{H}^{+}$resin, filtered and concentrated. The crude material was then purified by flash chromatography (10\% methanol in dichloromethane), giving cyclohexyl $\alpha$-L-rhamnopyranoside as a white solid

Cyclohexyl $\alpha$-L-rhamnopyranoside ( $246.15 \mathrm{mg}, 1 \mathrm{mmol}$ ) was then subjected to General Procedure $\mathrm{C}$ and acylated with benzoic anhydride. Product $2 \mathbf{i}$ was obtained as a white solid (222.0 $\mathrm{mg}, 63 \%)$ after flash column chromatography on silica ( $20 \%$ to $40 \%$ acetone in hexanes).

$\boldsymbol{R}_{\mathbf{f}}=0.36(30 \%$ acetone in hexanes)

${ }^{1} \mathbf{H}$ NMR (500 MHz, $\left.\mathbf{C D C l}_{3}\right): \delta(\mathrm{ppm})=8.06-8.03(\mathrm{~m}, 2 \mathrm{H}, \mathrm{Ar}-\mathbf{H}), 7.61-7.56(\mathrm{~m}, 1 \mathrm{H}, \mathrm{Ar}-\mathbf{H})$, 7.48-7.43 (m, 2H, Ar-H), $5.28(\mathrm{dd}, J=3.4,1.7 \mathrm{~Hz}, 1 \mathrm{H}, \mathrm{H}-2), 5.03$ (d, $J=1.6 \mathrm{~Hz}, 1 \mathrm{H}, \mathrm{H}-1), 4.12$ 4.09 (m, 1H, H-3), 3.88-3.82 (m, 1H, H-5), 3.65-3.58 (m, 1H, H-4), 1.90-1.83 (m, 2H, -Cy), 1.781.70 (m, 2H, -Cy), 1.56-1.48 (m, 1H, -Cy), 1.46-1.21 (m, 5H, -Cy), 1.36 (d, J=6.2 Hz, 3H, $\left.\mathrm{CH}_{3}\right)$.

${ }^{13} \mathbf{C}$ NMR (126 MHz, $\left.\mathbf{C D C l}_{3}\right): \delta(\mathrm{ppm})=166.7,133.6,130.0,129.7,128.6,95.7,75.8,74.1,73.9$, $70.9,68.1,33.4,31.6,25.7,24.2,23.9,17.8$.

IR (neat, cm-1 ): 3408 (w), 2931 (w), 2858 (w), 1715 (s), 1451 (s), 1290 (s), 1112 (s), 1048 (s), 1025 (s), 977 (s), 840 (s), 709 (s), 685 (s).

HRMS (DART ${ }^{+}, \mathrm{m} / \mathrm{z}$ ): ): calculated for $\mathrm{C}_{19} \mathrm{H}_{27} \mathrm{O}_{6}[\mathrm{M}+\mathrm{H}]^{+}: 351.18022$; found: 351.18022 .

$[\boldsymbol{\alpha}]_{\boldsymbol{D}}^{20}=-30.0\left(\mathrm{c}=7.00 \mathrm{mg} / \mathrm{mL}, \mathrm{CHCl}_{3}\right)$

$2 \mathrm{j} \quad-\quad 1,2,3,4-d i-O-i s o p r o p y l i d e n e-6-O-(2-O$-benzoyl- $\alpha$-L-rhamnopyranosyl)- $\alpha$-Dgalactopyranoside

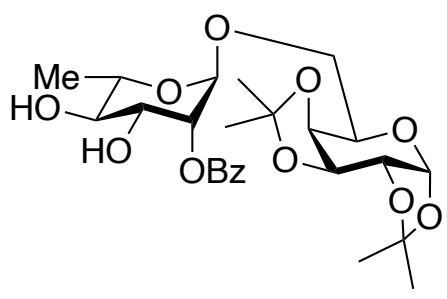


Prepared according to adapted literature procedures. ${ }^{14}$

To an oven-dried Schlenk flask was added $2.0 \mathrm{~g}$ of $4 \AA$ sieves and a magnetic stir bar. The flask was sealed with a rubber septum, evacuated and the sieves were activated using a heat gun. After 30 minutes, the flask was filled with argon and a solution of 2,3,4-tri-O-benzoyl- $\alpha$-Lrhamnopyranosyl bromide (4 mmol, 1 equiv.) and 1,2:3,4-Di-O-isopropylidene- $\alpha$-Dgalactopyranose (4 mmol, 1 equiv.) in $35 \mathrm{~mL}$ of a 1:1 mixture of dichloromethane and toluene was added to the flask. The reaction mixture for stirred for 10 minutes and then cooled to $-20{ }^{\circ} \mathrm{C}$. A solution of silver trifluoromethanesulfonate ( $4 \mathrm{mmol}, 1$ equiv.) in $15 \mathrm{~mL}$ of a $1: 1$ mixture of dichloromethane and toluene was added to the flask dropwise. The reaction mixture was then stirred at $-20^{\circ} \mathrm{C}$. After 45 minutes, the reaction was quenched by addition of $5 \mathrm{~mL}$ of pyridine, diluted with dichloromethane and filtered through a pad of celite. The solution was then washed with a 1:1 mixture of sat. aq. $\mathrm{NaHCO} 3$ and $1 \mathrm{M} \mathrm{Na} 2 \mathrm{~S} 2 \mathrm{O} 3$ and $\mathrm{H} 2 \mathrm{O}$ afterwards. The organic phase was then dried over $\mathrm{MgSO}$, filtered, and concentrated under reduced pressure. The crude material was then purified by flash chromatography (10 to $40 \%$ ethyl acetate in hexane). The product was transferred to an oven-dried, round-bottom flask, along with $\mathrm{NaOMe}$ (0.5 equiv.) and a magnetic stir bar. The flask was then evacuated and backfilled with argon three times on a Schlenk line. Under a balloon of argon, a 1:1 mixture of methanol and tetrahydrofuran ([sugar $]=0.2 \mathrm{M})$ was added and the mixture was stirred at room temperature. After 18 hours, the reaction was quenched with $\mathrm{H}^{+}$resin, filtered and concentrated. The crude material was then purified by flash chromatography (10\% methanol in dichloromethane), giving 1,2:3,4-di-O-isopropylidene-6-O- $\alpha$ L-rhamnopyranosyl- $\alpha$-D-galactopyranose as a white solid.

1,2:3,4-di-O-isopropylidene-6-O- $\alpha$-L-rhamnopyranosyl- $\alpha$-D-galactopyranose $\quad(243.8 \mathrm{mg}, \quad 0.6$ $\mathrm{mmol}$ ) was then subjected to General Procedure $\mathrm{C}$ and acylated with benzoic anhydride. Product 2j was obtained as a white solid (105 mg, $34 \%$ ) after flash column chromatography on silica (20 to $40 \%$ acetone in hexanes).

$\boldsymbol{R}_{\mathbf{f}}=0.28(30 \%$ acetone in hexanes $)$

${ }^{1}$ H NMR (500 MHz, CDCl 3$): \delta(\mathrm{ppm})=8.06-8.03(\mathrm{~m}, 2 \mathrm{H}, \mathrm{Ar}-\mathrm{H}), 7.60-7.57$ (m, 1H, Ar-H), $7.47-7.44(\mathrm{~m}, 2 \mathrm{H}, \mathrm{Ar}-\mathrm{H}), 5.53(\mathrm{~d}, J=5.0 \mathrm{~Hz}, 1 \mathrm{H}), 5.39(\mathrm{dd}, J=3.4,1.6 \mathrm{~Hz}, 1 \mathrm{H}), 4.94(\mathrm{~d}, J=1.7$ $\mathrm{Hz}, 1 \mathrm{H}), 4.63(\mathrm{dd}, J=8.0,2.4 \mathrm{~Hz}, 1 \mathrm{H}), 4.33(\mathrm{dd}, J=5.0,2.4 \mathrm{~Hz}, 1 \mathrm{H}), 4.27(\mathrm{dd}, J=8.0,2.0 \mathrm{~Hz}$, $1 \mathrm{H}), 4.07(\mathrm{dd}, J=9.4,3.6 \mathrm{~Hz}, 1 \mathrm{H}), 3.99(\mathrm{td}, J=6.4,1.5 \mathrm{~Hz}, 1 \mathrm{H}), 3.91-3.83(\mathrm{~m}, 2 \mathrm{H}), 3.64-3.58$ $(\mathrm{m}, 2 \mathrm{H}), 1.56(\mathrm{~s}, 3 \mathrm{H}), 1.45(\mathrm{~s}, 3 \mathrm{H}), 1.37(\mathrm{~d}, J=6.2 \mathrm{~Hz}, 3 \mathrm{H}), 1.35(\mathrm{~s}, 3 \mathrm{H}), 1.34(\mathrm{~s}, 3 \mathrm{H})$.

${ }^{13}$ C NMR (126 MHz, $\left.\mathbf{C D C l}_{3}\right): \delta(\mathrm{ppm})=166.6,133.6,130.3,130.0,129.6,109.5,108.8,97.8$, 96.4, 73.8, 73.0, 71.1, 71.0, 70.8, 70.7, 68.3, 66.7, 65.9, 31.7, 26.3, 26.1, 25.1, 24.6, 17.7.

IR (neat, cm-1 ): 3435 (w), 2989 (w), 2937 (w), 1718 (s), 1453 (s), 1377 (s), 1262 (s), 1211 (s), 1113 (s), 1060 (s), 1001 (s), 918 (s), 890 (s), 711 (s).

HRMS (DART ${ }^{+}, \mathrm{m} / \mathrm{z}$ ): calculated for $\mathrm{C}_{25} \mathrm{H}_{38} \mathrm{NO}_{11}\left[\mathrm{M}+\mathrm{NH}_{4}\right]^{+}$: 528.24394; found: 528.24441.

$[\boldsymbol{\alpha}]_{\boldsymbol{D}}^{20}=-59.2\left(\mathrm{c}=3.33 \mathrm{mg} / \mathrm{mL}, \mathrm{CHCl}_{3}\right)$ 


\section{2k - Methyl 4-O-benzoyl- $\alpha$-L-rhamnopyranoside}

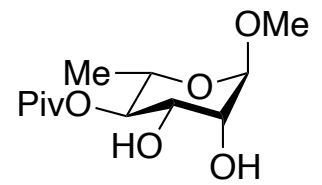

Prepared according to General Procedure B from methyl- $\alpha$-L-rhamnopyranoside.

The crude material was purified by flash column chromatography on silica ( $10 \%$ to $30 \%$ acetone in dichloromethane to afford $\mathbf{2} \mathbf{k}$ as a white solid (68\%).

$\boldsymbol{R}_{\mathbf{f}}=0.38(20 \%$ acetone in dichloromethane)

${ }^{1}$ H NMR (500 MHz, CDCl $): \delta(\mathrm{ppm})=4.74(\mathrm{t}, J=9.7 \mathrm{~Hz}, 1 \mathrm{H}, \mathrm{H}-4), 4.72(\mathrm{~d}, J=1.7 \mathrm{~Hz}, 1 \mathrm{H}, \mathrm{H}-$ 1), 3.93 (td, $J=3.8,1.7 \mathrm{~Hz}, 1 \mathrm{H}, \mathrm{H}-3), 3.87-3.77$ (m, $2 \mathrm{H}, \mathrm{H}-2, \mathrm{H}-5), 3.38$ (s, $\left.3 \mathrm{H},-\mathrm{CH}_{3}\right), 3.11$ (d, $J$ $=6.4 \mathrm{~Hz}, 1 \mathrm{H},-\mathrm{OH}), 2.72(\mathrm{~d}, J=4.2 \mathrm{~Hz}, 1 \mathrm{H},-\mathrm{OH}), 1.23\left(\mathrm{~s}, 9 \mathrm{H},-\mathrm{C}\left(\mathrm{CH}_{3}\right)_{3}\right) 1.22(\mathrm{~d}, J=7.0 \mathrm{~Hz}$, $\left.3 \mathrm{H},-\mathrm{CH}_{3}\right)$.

${ }^{13} \mathbf{C}$ NMR (125 MHz, $\left.\mathbf{C D C l}_{3}\right): \delta(\mathrm{ppm})=180.0,100.5,75.7,70.9,70.6,65.5,55.2,39.1,27.2$, 17.6.

IR (neat, cm-1 ): 3452 (w), 2955 (w), 1735 (s), 1481 (s), 1396 (s), 1280 (s), 1153 (s), 1066 (s)1036 (s), $972(\mathrm{~s}), 805(\mathrm{~s}), 791(\mathrm{~s}), 681(\mathrm{~s})$.

HRMS (DART $\left.{ }^{+}, \mathrm{m} / \mathrm{z}\right)$ : calculated for $\mathrm{C}_{12} \mathrm{H}_{23} \mathrm{O}_{6}[\mathrm{M}+\mathrm{H}]^{+}:$263.14957; found: 263.14891.

$[\boldsymbol{\alpha}]_{\boldsymbol{D}}^{\mathbf{2 0}}=-90.8\left(\mathrm{c}=6.07 \mathrm{mg} / \mathrm{mL}, \mathrm{CHCl}_{3}\right)$

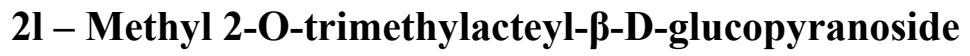

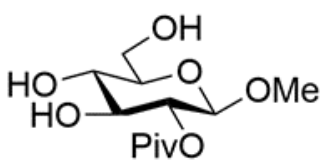

To a vigorously stirred, cooled (ice bath) biphasic solution of 3,4,6-tri-O-benzyl-D-glucal (3.00 mmol) in DCM (12 mL), acetone $(1.2 \mathrm{~mL})$ and sat. aq, $\mathrm{NaHCO}_{3}(20 \mathrm{~mL})$, a solution of Oxone ( $3.59 \mathrm{~g})$ in $\mathrm{H}_{2} \mathrm{O}(14 \mathrm{~mL})$ was added dropwise over $15 \mathrm{~min}$. The mixture was vigorously stirred at $0^{\circ} \mathrm{C}$ for $30 \mathrm{~min}$ and then at $23^{\circ} \mathrm{C}$ for an additional $2 \mathrm{~h}$. The reaction was then extracted with DCM. The combined organic phases were dried and concentrated to afford 3,4,6-tri-O-benzyl-D-glucal epoxide (90\%) as a white solid. ${ }^{15}$

3,4,6-tri-O-benzyl-D-glucal epoxide (1.4 mmol) was dissolved in DCM (1.2 $\mathrm{mL})$, and dry methanol $(1 \mathrm{~mL})$ was added. Reaction was stirred until TLC revealed full consumption of the 
starting material (ca. 2 hours). Reaction was concentrated under reduced pressure and the crude material was used without purification. ${ }^{16}$

Methyl 3,4,6-tri-O-benzyl- $\beta$-D-glucopyranoside ( $0.5 \mathrm{mmol})$ and DMAP ( $5 \mathrm{~mol} \%$ ) were dissolved in pyridine $\left(5 \mathrm{~mL}\right.$ ) and cooled to $0^{\circ} \mathrm{C}$. Trimethylacetyl chloride ( 3 equiv.) was added dropwise and the reaction mixture was heated to $40^{\circ} \mathrm{C}$ for several days until TLC revealed consumption of the starting material (ca. 4 days). The reaction was then extracted with DCM, washed with sat. aq. $\mathrm{NaHCO}_{3}$, dried and concentrated under reduced pressure. The resulting residue was purified by flash chromatography on silica gel (5\% to $20 \%$ ethyl acetate in hexane) to give methyl 3,4,6-triO-benzyl-2-O-pivaloyl- $\beta$-D-glucopyranoside as an off-white solid (85\%).

The benzylated glycoside was dissolved in $\mathrm{EtOH}$, and $\mathrm{Pd} / \mathrm{C}(10 \% \mathrm{w} / \mathrm{w})$ was added. The reaction mixture was purged with nitrogen, then the flask was purged with hydrogen three times. The reaction mixture was stirred at $23^{\circ} \mathrm{C}$ under hydrogen until TLC revealed consumption of the

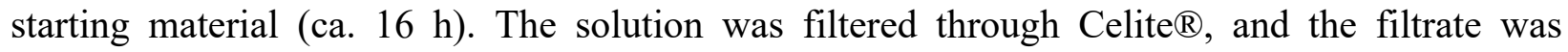
concentrated under vacuum. The residue was purified by column chromatography on silica gel ( $10 \%$ to $50 \%$ acetone in dichloromethane) to afford $\mathbf{2 l}$ as a white solid (81\%).

$\mathbf{R}_{\mathbf{f}}=0.28$ (Acetone:DCM 1:1)

${ }^{1}$ H NMR (500 MHz, $\left.\mathbf{C D C l}_{3}\right): \delta(\mathrm{ppm})=4.70(\mathrm{dd}, J=9.5,7.9 \mathrm{~Hz}, 1 \mathrm{H}), 4.38(\mathrm{~d}, J=7.9 \mathrm{~Hz}, 1 \mathrm{H})$, 3.95-3.84 (m, 2H), 3.72-3.57 (m, 3H), $3.50(\mathrm{~s}, 3 \mathrm{H}), 3.43-3.34(\mathrm{~m}, 2 \mathrm{H}), 2.72($ br s, $1 \mathrm{H}), 1.22(\mathrm{~s}$, $9 \mathrm{H})$

${ }^{13} \mathbf{C}$ NMR (125 MHz, $\left.\mathbf{C D C l}_{3}\right): \delta(\mathrm{ppm})=178.7,102.1,75.5,75.3,73.9,70.7,61.9,57.2,38.9$, 27.0

IR (neat, cm-1): 3412 (b), 2985 (s), 1738 (s), 1405 (s), 1485 (s), 1289 (s), 1161 (s), 1060 (s)

HRMS (DART ${ }^{+}, \mathrm{m} / \mathrm{z}$ ): calculated for $\mathrm{C}_{12} \mathrm{H}_{22} \mathrm{O}_{7}\left[\mathrm{M}+\mathrm{NH}_{4}\right]^{+}:$296.17093; found: 296.17038 $[\boldsymbol{\alpha}]_{\mathbf{D}}^{\mathbf{2 0}}=-19.4\left(\mathrm{c}=5 \mathrm{mg} / \mathrm{mL}, \mathrm{CHCl}_{3}\right)$

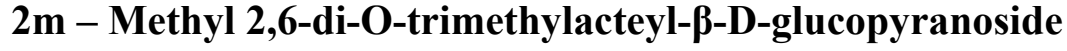

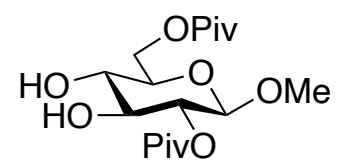

Synthesized according to adapted literature procedures. ${ }^{11}$

Methyl 2-O-pivaloyl- $\beta$-D-glucopyranoside (2l) was dissolved in pyridine, and cooled to $0{ }^{\circ} \mathrm{C}$, followed by addition of trimethylacetyl chloride ( 2 equiv.). Reaction was warmed to $23{ }^{\circ} \mathrm{C}$ and stirred until TLC revealed consumption of the starting material (ca. 2 hours). The reaction was then diluted with ethyl acetate and the organic layer was washed with $1 \mathrm{M} \mathrm{HCl}$, sat. aq. $\mathrm{NaHCO}_{3}$, 
and brine, then dried and concentrated under reduced pressure. The resulting residue was purified by flash column chromatography on silica gel (10\% to 30\% acetone in dichloromethane) to afford $\mathbf{2 m}$ as a white solid (55\%).

$\mathbf{R}_{\mathbf{f}}=0.45(20 \%$ acetone in dichloromethane)

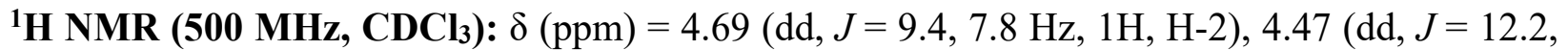
$4.8 \mathrm{~Hz}, 1 \mathrm{H}, \mathrm{H}-6 \mathrm{a}), 4.37$ (d, $J=7.8 \mathrm{~Hz}, 1 \mathrm{H}, \mathrm{H}-1$ ), 4.34 (dd, $J=12.1,2.3 \mathrm{~Hz}, 1 \mathrm{H}, \mathrm{H}-6 \mathrm{~b}$ ), 3.62 (dd, $J=8.8,8.8 \mathrm{~Hz}, 1 \mathrm{H}, \mathrm{H}-3), 3.48\left(\mathrm{~s}, 3 \mathrm{H},-\mathrm{OCH}_{3}\right), 3.47(\mathrm{dd}, J=4.8,2.4 \mathrm{~Hz}, 1 \mathrm{H}, \mathrm{H}-5), 3.41(\mathrm{~d}, J=$ $8.8 \mathrm{~Hz}, 1 \mathrm{H}, \mathrm{H}-4), 1.23\left(\mathrm{~s}, 9 \mathrm{H},-\mathrm{C}\left(\mathrm{CH}_{3}\right)_{3}\right), 1.23\left(\mathrm{~s}, 9 \mathrm{H},-\mathrm{C}\left(\mathrm{CH}_{3}\right)_{3}\right)$.

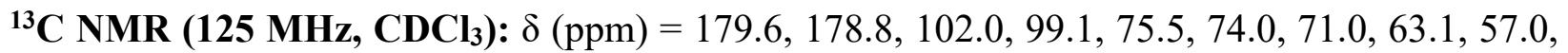
$39.1,27.3,27.2$.

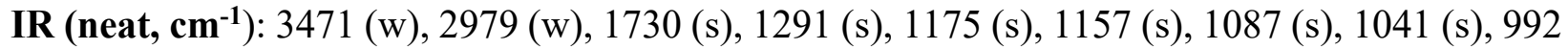
(s), $815(\mathrm{~s})$.

HRMS (DART ${ }^{+}, \mathrm{m} / \mathrm{z}$ ): calculated for $\mathrm{C}_{17} \mathrm{H}_{34} \mathrm{NO}_{8}\left[\mathrm{M}+\mathrm{NH}_{4}\right]^{+}:$380.22805; found: 380.22789 .

$[\boldsymbol{\alpha}]_{\mathbf{D}}^{\mathbf{2 0}}=-22.6\left(\mathrm{c}=3.25 \mathrm{mg} / \mathrm{mL}, \mathrm{CHCl}_{3}\right)$

\section{$\underline{\text { Reaction Optimization }}$}

\section{Optimization Procedure}
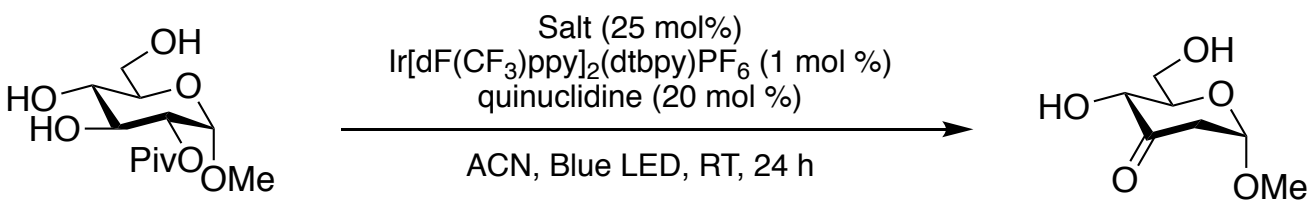

Methyl 2-O-trimethylacetylglucopyranoside $\quad(27.8 \quad \mathrm{mg}, \quad 0.10 \quad \mathrm{mmol}, \quad 1 \quad$ equiv.), $\left(\operatorname{Ir}\left[\mathrm{dF}\left(\mathrm{CF}_{3}\right) \text { ppy }\right]_{2}(\mathrm{dtbpy})\right) \mathrm{PF}_{6}(1 \mathrm{mg}, 0.001 \mathrm{mmol}, 1 \mathrm{~mol} \%)$, quinuclidine (2.2 $\mathrm{mg}, 0.02 \mathrm{mmol}, 20$ mol \%), salt additive $(0.025 \mathrm{mmol}, 25 \mathrm{~mol} \%)$ and a small magnetic stir bar were added to a $1 / 2$ dram vial. A rubber septum was used to seal the vial, which was then evacuated and backfilled with argon three times on a Schlenk line. Dry, degassed acetonitrile $(0.8 \mathrm{~mL})$ was added to the vial under a balloon of argon. The rubber septum was removed and quickly replaced with the vial cap which was sealed with Teflon tape and parafilm. The vial was placed 5 inches away from a blue LED Kessil lamp and stirred at $1050 \mathrm{rpm}$ for 24 hours at $25^{\circ} \mathrm{C}$. After 24 hours the crude reaction was concentrated under reduced pressure and analyzed by ${ }^{1} \mathrm{H}$ NMR Spectroscopy. 
Table S1. Evaluation of the hydrogen bond acceptor catalyst.

\begin{tabular}{|c|c|c|c|}
\hline Entry & Salt & NMR yield ${ }^{a}$ & $\begin{array}{l}\text { NMR yield }{ }^{\mathrm{a}} \text { with } 1 \text { eq } \\
\mathrm{K}_{2} \mathrm{CO}_{3}\end{array}$ \\
\hline 1 & TBAP & - & $67 \%$ \\
\hline 2 & & $35 \%$ & $40 \%$ \\
\hline 3 & & $70 \%$ & $71 \%$ \\
\hline 4 & & $70 \%$ & $64 \%$ \\
\hline 5 & & $70 \%$ & $64 \%$ \\
\hline 6 & & $69 \%$ & - \\
\hline 7 & & $45 \%$ & $56 \%$ \\
\hline 8 & $\begin{array}{r}\mathrm{O} \\
\mathrm{BuO}-\mathrm{P}_{1} \\
\mathrm{O}\end{array}$ & $37 \%$ & $56 \%$ \\
\hline 9 & $\begin{array}{r}\text { O } \\
\text { BuO-P-C } \\
\text { O- } \\
\text { - }\end{array}$ & $57 \%$ & $76 \%$ \\
\hline 10 & $\begin{array}{r}\mathrm{O} \\
\mathrm{PhO}-\mathrm{P}_{1} \\
\mathrm{O}\end{array}$ & $22 \%$ & - \\
\hline
\end{tabular}


Table S2. Control Reactions

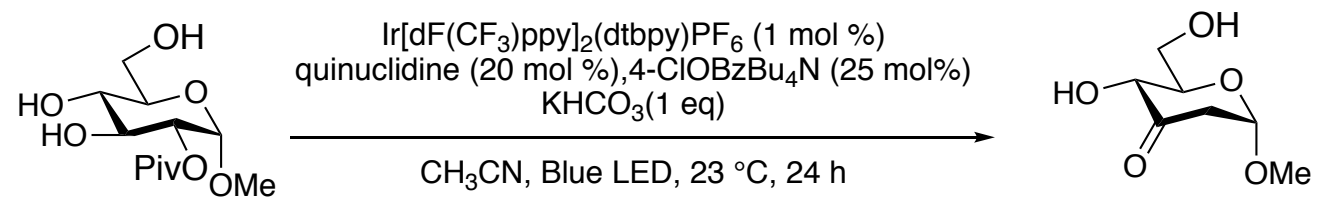

\begin{tabular}{|c|c|c|c|}
\hline Entry & Changes to Above & NMR Yield $4 a^{a}$ & $\begin{array}{c}\text { Remaining } \\
\text { Starting Material }^{\mathrm{a}}\end{array}$ \\
\hline 1 & No Ir. cat & $<5 \%$ & $91 \%$ \\
\hline 2 & No quinuclidine & $<5 \%$ & $92 \%$ \\
\hline 3 & No blue LED light & $<5 \%$ & $83 \%$ \\
\hline 4 & No 4-ClOBzBu${ }_{4} \mathrm{~N}$ & $30 \%$ & $56 \%$ \\
\hline
\end{tabular}

${ }^{a}$ Yields of 4a were determined via ${ }^{1} \mathrm{H}$ NMR spectra of the crude mixture (integration of the ddd at $2.82 \mathrm{ppm}$ relative to internal standard 1,3,5-trimethoxybenzene).

Table S3. Effects on the ratio of HBA catalyst to quinuclidine on the yield of $4 \mathbf{a}$.
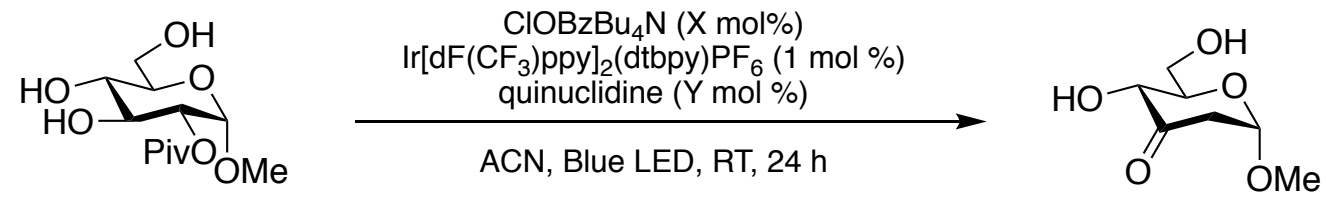

\begin{tabular}{|c|c|c|c|c|}
\hline & & & $\begin{array}{l}\mathrm{BzzBu} \\
\mathrm{mol} \%\end{array}$ & \\
\hline & & 25 & 50 & 100 \\
\hline & 10 & $62 \%$ & $61 \%$ & $45 \%$ \\
\hline $\begin{array}{l}\text { quinuclidine } \\
\text { (mol \%) }\end{array}$ & 20 & $70 \%$ & $59 \%$ & \\
\hline & 30 & $15 \%$ & & $53 \%$ \\
\hline
\end{tabular}




\section{Characterization of Products}

\section{General Procedure D for reactions run with solid acylated sugar}

Pyranoside derivative (1 equiv.), $\left(\operatorname{Ir}\left[\mathrm{dF}_{(}\left(\mathrm{CF}_{3}\right) \mathrm{ppy}\right]_{2}(\mathrm{dtbpy})\right) \mathrm{PF}_{6}(1 \mathrm{~mol} \%)$, quinuclidine (20 mol\%), tetrabutylammonium 4-chlorobenzoate ( $25 \mathrm{~mol} \%)$, potassium bicarbonate (1 equiv.) and a small magnetic stir bar were added to a 1 dram vial. A rubber septum was used to seal the vial, which was then evacuated and backfilled with argon three times on a Schlenk line. Dry, degassed acetonitrile $(0.125 \mathrm{M})$ was added to the vial under a balloon of argon. The rubber septum was removed and quickly replaced with the vial cap which was sealed with Teflon tape and parafilm. The vial was placed 5 inches from a blue LED Kessil lamp and stirred at $1050 \mathrm{rpm}$ for 24 hours at $25^{\circ} \mathrm{C}$. After 24 hours the crude reaction was concentrated under reduced pressure and analyzed by ${ }^{1} \mathrm{H}$ NMR spectroscopy. The crude material was then subjected to flash column chromatography on silica.

\section{General Procedure E for reactions run with non-solid acylated sugar}

$\left(\operatorname{Ir}\left[\mathrm{dF}\left(\mathrm{CF}_{3}\right) \mathrm{ppy}\right]_{2}(\mathrm{dtbpy})\right) \mathrm{PF}_{6}$ (1 mol\%), quinuclidine (20 mol\%), tetrabutylammonium 4chlorobenzoate ( $25 \mathrm{~mol} \%)$, potassium bicarbonate (1 equiv.) and a small magnetic stir bar were added to a 1 dram vial. A rubber septum was used to seal the vial, which was then evacuated and backfilled with argon three times on a Schlenk line. A $0.125 \mathrm{M}$ solution of the pyranoside derivative was prepared under argon in dry degassed acetonitrile. $1.6 \mathrm{~mL}$ of the solution (1 equiv.) was added to the vial under a balloon of argon. The rubber septum was removed and quickly replaced with the vial cap which was sealed with Teflon tape and parafilm. The vial was placed 5 inches from a blue LED Kessil lamp and stirred at $1050 \mathrm{rpm}$ for 24 hours at $25^{\circ} \mathrm{C}$. After 24 hours the crude reaction was concentrated under reduced pressure and analyzed by ${ }^{1} \mathrm{H}$ NMR spectroscopy. The crude material was then subjected to flash column chromatography on silica.

\section{4a - Methyl 2-deoxy- $\alpha$-D-erythro-hexopyranoside-3-ulose}

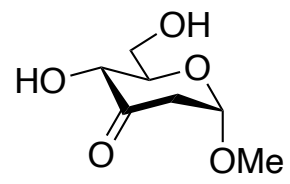

Prepared according to General Procedure $\mathrm{D}$ from methyl 2-O-trimethylacetyl- $\alpha$-Dglucopyranoside (2a) $(55.6 \mathrm{mg}, 0.2 \mathrm{mmol})$. 4a was obtained as a pale yellow oil (23.5 $\mathrm{mg}, 67 \%)$ after flash column chromatography on silica ( 20 to $40 \%$ acetone in dichloromethane).

The amount of remaining starting material in the reaction was found to be $25 \%$ by analysis of the crude ${ }^{1} \mathrm{H}$ NMR spectra relative to internal standard 1,3,5-trimethoxybenzene.

$\boldsymbol{R}_{\mathbf{f}}=0.33$ (40\% acetone in dichloromethane) 
${ }^{1}$ H NMR (500 MHz, CDCl $): \delta(p p m)=5.17(\mathrm{~d}, J=4.4 \mathrm{~Hz}, 1 \mathrm{H}, \mathrm{H}-1), 4.23(\mathrm{dd}, J=9.8,2.2 \mathrm{~Hz}$, $1 \mathrm{H}, \mathrm{H}-4), 3.98$ (dd, $J=11.9,2.8 \mathrm{~Hz}, 1 \mathrm{H}, \mathrm{H}-6), 3.92$ (dd, $J=12.0,3.7 \mathrm{~Hz}, 1 \mathrm{H}, \mathrm{H}-6), 3.76-3.72$ (m, $1 \mathrm{H}, \mathrm{H}-5), 3.35$ (s, 3H, $-\mathrm{OCH}_{3}$ ), 2.82 (ddd, $\left.J=14.0,4.6,1.4 \mathrm{~Hz}, 1 \mathrm{H}, \mathrm{H}-2\right), 2.70$ (dd, $J=14.0,1.1$ $\mathrm{Hz}, 1 \mathrm{H}, \mathrm{H}-2)$.

${ }^{13}$ C NMR (126 MHz, CDCl $): \delta(p p m)=205.4,100.1,74.8,73.3,62.6,55.1,45.2$.

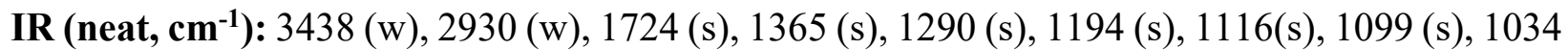
(s), $1002(\mathrm{~s}), 955$ (s), 878 (s), 840 (s).

HRMS (DART ${ }^{+}, \mathrm{m} / \mathrm{z}$ ): calculated for $\mathrm{C}_{7} \mathrm{H}_{16} \mathrm{NO}_{5}\left[\mathrm{M}+\mathrm{NH}_{4}\right]^{+}:$194.10230, found: 19410223 .

$[\alpha]_{D}^{20}=+117.1\left(\mathrm{c}=11.75 \mathrm{mg} / \mathrm{mL}, \mathrm{CHCl}_{3}\right)$

4b - Methyl 2-deoxy-6-O-(tert-butyldimethylsilyl)- $\alpha$-D-erythro-hexopyranoside-3-ulose

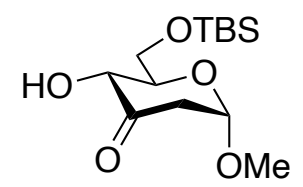

Prepared according to General Procedure D from methyl 2-O-trimethylacetyl-6-O-(tertbutyldimethylsilyl)- $\alpha$-D-glucopyranoside (2b) (78.5 mg, $0.2 \mathrm{mmol}$ ). Product (4b) was obtained as an off white solid $(47.4 \mathrm{mg}, 66 \%$ ) after flash column chromatography on silica (10 to $20 \%$ ethyl acetate in hexanes).

The amount of remaining starting material in the reaction was found to be $0 \%$ by analysis of the crude ${ }^{1} \mathrm{H}$ NMR spectra relative to internal standard 1,3,5-trimethoxybenzene.

$\boldsymbol{R}_{\mathbf{f}}=0.45(20 \%$ ethyl acetate in hexanes $)$

${ }^{1}$ H NMR (500 MHz, $\left.\mathbf{C D C l}_{3}\right): \delta(\mathrm{ppm})=5.16(\mathrm{~d}, J=4.4 \mathrm{~Hz}, 1 \mathrm{H}, \mathrm{H}-1), 4.18(\mathrm{dd}, J=9.8,1.3 \mathrm{~Hz}$, $1 \mathrm{H}, \mathrm{H}-4), 3.98$ (dd, $J=11.4,2.1 \mathrm{~Hz}, 1 \mathrm{H}, \mathrm{H}-6), 3.93$ (dd, $J=11.4,4.5 \mathrm{~Hz}, 1 \mathrm{H}, \mathrm{H}-6), 3.69-3.65$ (m, $1 \mathrm{H}, \mathrm{H}-5), 3.34$ (s, 3H, $\left.-\mathrm{OCH}_{3}\right), 2.80$ (ddd, $\left.J=14.0,4.6,1.4 \mathrm{~Hz}, 1 \mathrm{H}, \mathrm{H}-2\right), 2.68$ (dd, $J=14.0,1.0$

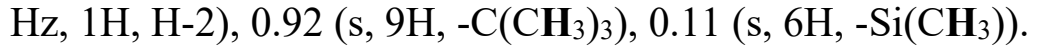

${ }^{13} \mathbf{C}$ NMR (126 MHz, $\left.\mathbf{C D C l}_{3}\right): \delta(\mathrm{ppm})=206.1,99.9,75.6,73.2,73.1,63.0,54.9,45.3,27.2,26.1$, $18.6,-5.1,-5.2$.

IR (neat, cm$^{-1}$ ): 3410 (w), 2935 (w), 2857 (s), 1730 (s), 1472 (s), 1412 (s), 1368 (s), 1291 (s), 1251 (s), 1098 (s), 1033 (s), 942 (s), 885 (s), 835 (s), 775 (s).

HRMS (DART ${ }^{+}, \mathrm{m} / \mathrm{z}$ ): calculated for $\mathrm{C}_{13} \mathrm{H}_{27} \mathrm{O}_{5} \mathrm{Si}[\mathrm{M}+\mathrm{H}]^{+}:$: 291.16223, found: 261.16262.

$[\boldsymbol{\alpha}]_{\boldsymbol{D}}^{\mathbf{2 0}}=+89.5\left(9.55 \mathrm{mg} / \mathrm{mL}, \mathrm{CHCl}_{3}\right)$. 
4c - Methyl 2-deoxy-6-O-trimethylacetyl- $\alpha$-D-erythro-hexopyranoside-3-ulose

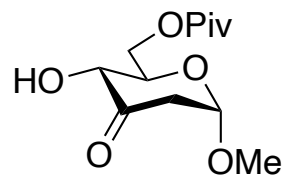

Prepared according to General Procedure D from methyl 2,6-di- $O$-trimethylacetyl- $\alpha$-Dglucopyranoside $(\mathbf{2 c})(72.5 \mathrm{mg}, 0.2 \mathrm{mmol})$. Product $(\mathbf{4 c})$ was obtained as a pale yellow oil (45.3mg, 87\%) after flash column chromatography on silica (0 to 5\% acetone in dichloromethane).

$\boldsymbol{R}_{\mathbf{f}}=0.56(5 \%$ acetone in dichloromethane)

${ }^{1}$ H NMR (500 MHz, CDCl $\left.{ }_{3}\right): \delta(\mathrm{ppm})=5.15(\mathrm{~d}, J=4.3 \mathrm{~Hz}, 1 \mathrm{H}, \mathrm{H}-1), 4.49(\mathrm{dd}, J=12.0,2.2 \mathrm{~Hz}$, $1 \mathrm{H}, \mathrm{H}-6 \mathrm{a}), 4.36$ (dd, $J=12.0,6.0 \mathrm{~Hz}, 1 \mathrm{H}, \mathrm{H}-6 \mathrm{~b}), 4.09$ (d, $J=8.8 \mathrm{~Hz}, 1 \mathrm{H}, \mathrm{H}-4), 3.91-3.88$ (m, 1H, H-5), 3.36 (s, 3H, $\left.-\mathrm{OCH}_{3}\right), 2.83$ (ddd, $\left.J=14.0,4.6,1.4 \mathrm{~Hz}, 1 \mathrm{H}, \mathrm{H}-2 \mathrm{a}\right), 2.71$ (dd, $J=14.0,1.1 \mathrm{~Hz}$, $1 \mathrm{H}, \mathrm{H}-2 \mathrm{~b}), 1.24\left(\mathrm{~s}, 9 \mathrm{H},-\mathrm{C}\left(\mathrm{CH}_{3}\right)_{3}\right)$.

${ }^{13}$ C NMR (126 MHz, $\left.\mathbf{C D C l}_{3}\right): \delta(\mathrm{ppm})=204.7,178.3,99.7,73.5,73.0,63.6,55.0,45.2,39.1$ 27.4, 27.2.

IR (neat, cm-1): 3469 (w), 2982 (w), 1726 (s), 1482 (s), 1366 (s), 1285 (s), 1150 (s), 1119 (s), 1102 (s), 1036 (s). 950 (s), 770 (s).

HRMS (DART ${ }^{+}, \mathrm{m} / \mathrm{z}$ ): calculated for $\mathrm{C}_{12} \mathrm{H}_{21} \mathrm{O}_{6}[\mathrm{M}+\mathrm{H}]^{+}:$261.13383, found: 261.13326.

$[\alpha]_{D}^{\mathbf{2 0}}=+112.2\left(\mathrm{c}=4.87 \mathrm{mg} / \mathrm{mL}, \mathrm{CHCl}_{3}\right)$

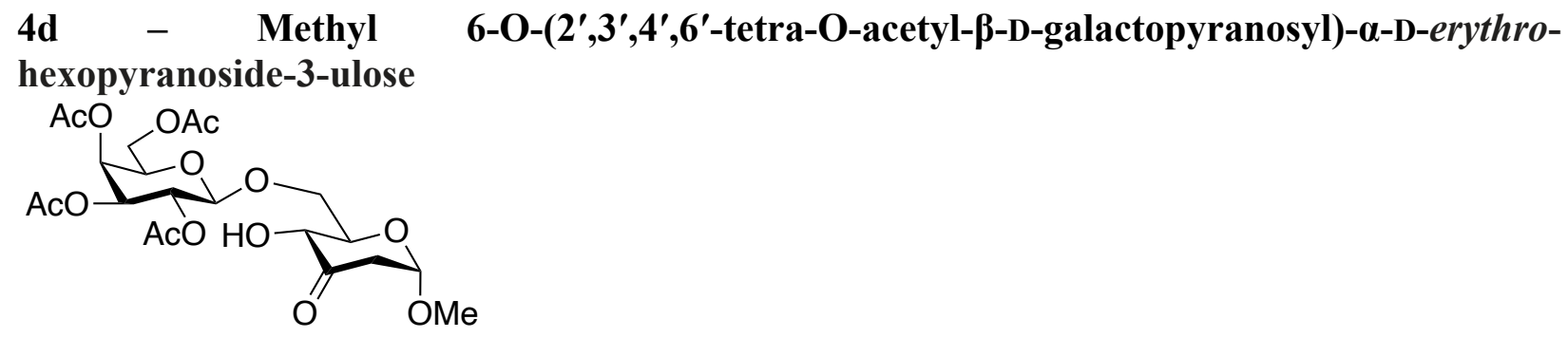

Prepared according to General Procedure D from methyl 2-O-Trimethylacetyl-6-O- $\left(2^{\prime}, 3^{\prime}, 4^{\prime}, 6^{\prime}-\right.$ tetra-O-acetyl- $\beta$-D-galactopyranosyl)- $\alpha$-D-glucopyranoside (2d). Product (4d) was obtained as a yellow amorphous solid $(41.9 \mathrm{mg}, 83 \%)$ after flash column chromatography on silica (0 to $10 \%$ acetone in dichloromethane).

$\mathbf{R}_{\boldsymbol{f}}=0.33$ (5\% acetone in dichloromethane) 
${ }^{1} \mathbf{H}$ NMR (500 MHz, $\left.\mathbf{C D C l}_{3}\right): \delta(\mathrm{ppm})=5.40(\mathrm{dd}, J=3.4,1.2 \mathrm{~Hz}, 1 \mathrm{H}, \mathrm{H}-4$ ') 5.28 (dd, $J=10.9$, $8.3 \mathrm{~Hz}, 1 \mathrm{H}, \mathrm{H}-2$ '), 5.14 (d, $J=4.0 \mathrm{~Hz}, 1 \mathrm{H}, \mathrm{H}-1), 5.04$ (dd, $J=10.5,3.4 \mathrm{~Hz}, 1 \mathrm{H}, \mathrm{H}-3$ '), 4.55 (d, $J$ $=8.0 \mathrm{~Hz}, 1 \mathrm{H}, \mathrm{H}-1$ '), 4.26 (dd, $J=10.6,1.2 \mathrm{~Hz}, 1 \mathrm{H}), 4.24-4.12$ (m, 3H, H-6', H-6', H-6), 3.94 (td, $J=6.8,1.2 \mathrm{~Hz}, 1 \mathrm{H}, \mathrm{H}-6), 3.85-3.79$ (m, 2H, H-5, H-5'), 3.53 (d, $J=4.0 \mathrm{~Hz}, 1 \mathrm{H},-\mathrm{OH}), 3.33$ (s, $\left.3 \mathrm{H},-\mathrm{OCH}_{3}\right), 2.83$ (ddd, $\left.J=14.1,4.6,1.3 \mathrm{~Hz}, 1 \mathrm{H}, \mathrm{H}-2 \mathrm{a}\right), 2.68$ (dd, $J=14.1,1.1 \mathrm{~Hz}, 1 \mathrm{H}, \mathrm{H}-2 \mathrm{~b}$ ), 2.13 (s, 3H, $-\mathrm{CO}\left(\mathrm{CH}_{3}\right), 2.05$ (s, 3H, $-\mathrm{CO}\left(\mathrm{CH}_{3}\right), 2.04$ (s, 3H, $-\mathrm{CO}\left(\mathrm{CH}_{3}\right), 1.98\left(\mathrm{~s}, 3 \mathrm{H},-\mathrm{CO}\left(\mathrm{CH}_{3}\right)\right.$.

${ }^{13}$ C NMR (126 MHz, CDCl $): \delta(p p m)=205.5,170.6,170.4,170.3,169.8,102.2,99.9,73.6$, 72.9, 70.9, 70.9, 69.6, 69.0, 67.1, 61.4, 55.1, 45.2, 31.1, 20.8, 20.8, 20.8, 20.7.

IR (neat, cm-1): 3490 (w), 2937 (w), 1738 (s), 1427 (w), 1368 (s), 1218 (s), 1176 (s), 1103 (s), 1042 (s), 952 (s), 908 (s), 878 (s), 736 (s).

\section{4e - Methyl 4-deoxy-6-O-(tert-butyldimethylsilyl)- $\alpha$-D-erythro-hexopyranoside-3-ulose}

TBSO

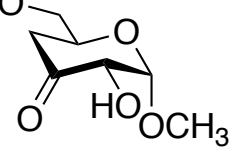

Prepared according to General Procedure E from methyl 4-O-trimethylacetyl-6-O-(tertbutyldimethylsilyl)- $\alpha$-D-mannopyranoside (2g) (78.5 $\mathrm{mg}, 0.2 \mathrm{mmol})$. Product (4e) was obtained as yellow solid (33.1 mg, 57\%) after flash column chromatography on silica (20 to $40 \%$ ethyl acetate in hexanes).

The amount of remaining starting material in the reaction was found to be $0 \%$ by analysis of the crude ${ }^{1} \mathrm{H}$ NMR spectra relative to internal standard 1,3,5-trimethoxybenzene.

$\mathbf{R}_{\boldsymbol{f}}=0.66$ (30\% ethyl acetate in hexanes)

${ }^{1}$ H NMR (500 MHz, CDCl 3$): \delta(\mathrm{ppm})=5.16(\mathrm{~d}, J=4.3,1 \mathrm{H}, \mathrm{H}-1), 4.18(\mathrm{ddd}, J=9.8,3.8,1.3$ Hz, 1H, H-2), 3.98 (dd, $J=11.4,2.1 \mathrm{~Hz}, 1 \mathrm{H}, \mathrm{H}-6), 3.94$ (dd, $J=11.3,4.5 \mathrm{~Hz}, 1 \mathrm{H}, \mathrm{H}-6), 3.67$ (m, $1 \mathrm{H}, \mathrm{H}-5), 3.54$ (d, $J=3.9,1 \mathrm{H},-\mathrm{OH}) 3.34$ (s, 3H, $\left.-\mathrm{OCH}_{3}\right), 2.80$ (ddd, $J=14.0,4.6,1.4 \mathrm{~Hz}, 1 \mathrm{H}, \mathrm{H}-$ 4), $2.68(\mathrm{dd}, J=14.0,1.1 \mathrm{~Hz}, 1 \mathrm{H}, \mathrm{H}-4), 0.92\left(\mathrm{~s}, 9 \mathrm{H},-\mathrm{C}\left(\mathrm{CH}_{3}\right)_{3}\right), 0.11\left(\mathrm{~s}, 6 \mathrm{H},-\mathrm{Si}\left(\mathrm{CH}_{3}\right)_{2}\right)$.

${ }^{13} \mathbf{C}$ NMR (126 MHz, $\left.\mathbf{C D C l}_{3}\right): \delta(\mathrm{ppm})=206.1,99.9,75.6,73.1,63.0,54.9,45.3,26.1,18.6$, $-5.1,-5.2$.

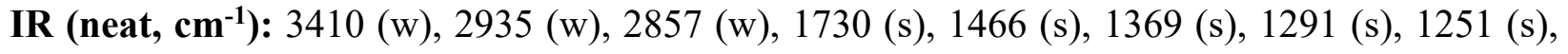
1193 (s), 1135 (s), 1098 (s), 1032 (s), 834 (s), 776 (s), 571 (s).

HRMS (DART ${ }^{+}, \mathrm{m} / \mathrm{z}$ ): calculated for $\mathrm{C}_{13} \mathrm{H}_{27} \mathrm{O}_{5} \mathrm{Si}[\mathrm{M}+\mathrm{H}]^{+}:$: 291.16223, found: 261.16115.

$[\alpha]_{D}^{20}=+58.5\left(6.85 \mathrm{~g} / \mathrm{mL}, \mathrm{CHCl}_{3}\right)$ 


\section{4f - Methyl 2,6-dideoxy- $\alpha$-D-erythro-hexopyranoside-3-ulose}<smiles>COC1CC(=O)C(O)C(C)C1C</smiles>

Prepared according to General Procedure E from methyl 2- $O$-benzoyl- $\alpha$-L-rhamnopyranoside (2h) (56.5 mg, $0.2 \mathrm{mmol})$. Product (4f) was obtained as a yellow oil (23.0 mg, 72\%) after flash column chromatography on silica (0 to $5 \%$ acetone in dichloromethane).

The amount of remaining starting material in the reaction was found to be $0 \%$ by analysis of the crude ${ }^{1} \mathrm{H}$ NMR spectra relative to internal standard 1,3,5-trimethoxybenzene.

$\mathbf{R}_{\boldsymbol{f}}=0.57$ (5\% acetone in dichloromethane)

${ }^{1}$ H NMR (500 MHz, $\left.\mathbf{C D C l}_{3}\right): \delta(\mathrm{ppm})=5.08(\mathrm{~d}, J=4.5 \mathrm{~Hz}, 1 \mathrm{H}, \mathrm{H}-1), 3.83(\mathrm{dd}, J=9.5,2.4 \mathrm{~Hz}$, $1 \mathrm{H}, \mathrm{H}-5), 3.55$ (d, $J=3.5 \mathrm{~Hz}, 1 \mathrm{H}, \mathrm{H}-4), 3.33$ (s, 3H, $\left.-\mathrm{OCH}_{3}\right), 2.81$ (ddd, $J=14.0,4.6,1.3 \mathrm{~Hz}, 1 \mathrm{H}$, $\mathrm{H}-2), 2.67$ (dd, $J=14.0,1.0 \mathrm{~Hz}, 1 \mathrm{H}, \mathrm{H}-2), 1.44$ (d, $\left.J=5.9 \mathrm{~Hz}, 3 \mathrm{H},-\mathrm{CH}_{3}\right)$.

${ }^{13} \mathbf{C}$ NMR (126 MHz, $\left.\mathbf{C D C l}_{3}\right): \delta(\mathrm{ppm})=205.4,99.7,78.6,71.0,54.9,45.3,18.9$.

IR (neat, cm-1): 3448 (w), 2918 (w), 1723 (s), 1236 (s), 1193 (s), 1118 (s), 1065 (s), 1038 (s), 958 (s), $878(\mathrm{~s}), 610(\mathrm{~s}), 569(\mathrm{~s})$.

HRMS (DART ${ }^{+}, \mathrm{m} / \mathrm{z}$ ): calculated for $\mathrm{C}_{7} \mathrm{H}_{16} \mathrm{NO}_{4}\left[\mathrm{M}+\mathrm{NH}_{4}\right]^{+}$: 178.10738 , found: 178.10710 .

$[\boldsymbol{\alpha}]_{D}^{20}=-148.6\left(6.40 \mathrm{mg} / \mathrm{mL}, \mathrm{CHCl}_{3}\right)$

\section{$\underline{2.5 \mathrm{mmol} \text { Scale Reaction }}$}

Methyl 2- $O$-benozyl- $\alpha$-L-rhamnopyranoside $\quad(705.7 \quad \mathrm{mg}, \quad 2.5 \mathrm{mmol}, \quad 1 \quad$ equiv.), $\left(\operatorname{Ir}\left[\mathrm{dF}\left(\mathrm{CF}_{3}\right) \mathrm{ppy}\right]_{2}(\mathrm{dtbpy})\right) \mathrm{PF}_{6}(28.0 \mathrm{mg}, 0.25 \mathrm{mmol}, 1 \mathrm{~mol} \%)$, quinuclidine (55.6 mg, $0.5 \mathrm{mmol}, 20$ mol\%), tetrabutylammonium 4-chlorobenzoate ( $248.8 \mathrm{mg}, 0.625 \mathrm{mmol}, 25 \mathrm{~mol} \%$ ), potassium bicarbonate (250.0 mg, $2.5 \mathrm{mmol}, 1$ equiv.) and a magnetic stir bar were added to a 9.5 dram vial. A rubber septum was used to seal the vial, which was then evacuated and backfilled with argon three times on a Schlenk line. Dry, degassed acetonitrile $(0.125 \mathrm{M})$ was added to the vial under a balloon of argon. The rubber septum was removed and quickly replaced with the vial cap which was sealed with Teflon tape and parafilm. The vial was placed 5 inches from three blue LED Kessil lamps and stirred at $1050 \mathrm{rpm}$ for 24 hours at $25^{\circ} \mathrm{C}$. After 24 hours the crude reaction was washed with saturated aqueous sodium bicarbonate. The organic layer was dried over $\mathrm{MgSO}_{4}$, filtered, and concentrated under reduced pressure. The crude material was purified by flash column chromatography on silica ( 0 to $5 \%$ acetone in dichloromethane) to afford (4f) as a yellow oil (271.9 $\mathrm{mg}, 68 \%)$. 
4g - Cyclohexyl 2,6-dideoxy- $\alpha$-D-erythro-hexopyranoside-3-ulose

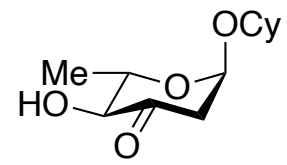

Prepared according to General Procedure D from cyclohexyl 2- $O$-benzoyl- $\alpha$-L-rhamnopyranoside (2i) $(70.1 \mathrm{mg}, 0.2 \mathrm{mmol})$. Product (4g) was obtained as a pale yellow solid (28.5mg, 63\%) after flash column chromatography on silica ( 0 to $5 \%$ acetone in dichloromethane).

$\mathbf{R}_{\boldsymbol{f}}=0.68$ (5\% acetone in dichloromethane)

${ }^{1}$ H NMR (500 MHz, CDCl 3$): ~ \delta(p p m)=5.35(\mathrm{~d}, J=4.7 \mathrm{~Hz}, 1 \mathrm{H}, \mathrm{H}-1), 3.90-3.84$ (m, 1H, H-5), 3.81 (ddd, $J=9.5,3.8,1.4 \mathrm{~Hz}, 1 \mathrm{H}, \mathrm{H}-4), 3.59-3.53$ (m, 1H, -OH), 2.81 (ddd, $J=13.9,4.8,1.4$ Hz, 1H, H-2), 2.63 (dd, J=13.9, 1.0 Hz, 1H, H-2), 1.87-1.76 (m, 2H, -Cy), 1.75-1.67 (m, 2H, Cy), 1.54-1.48 (m, 1H, -OCH-), 1.42 (d, $\left.J=6.0 \mathrm{~Hz}, 3 \mathrm{H},-\mathrm{CH}_{3}\right), 1.39-1.15$ (m, 5H, -Cy).

${ }^{13}$ C NMR (126 MHz, CDCl 3$): ~ \delta(p p m)=205.8,96.5,78.7,76.9,71.2,45.9,33.4,31.4,25.7,24.2$, 24.0, 18.8 .

IR (neat, cm-1): 3442 (w), 2933 (w), 2859 (w), 1719 (s), 1451 (s), 1380 (s), 1282 (s), 1143 (s), 1087 (s), 1062 (s), 1013 (s), 980 (s), 958 (s), 924 (s), 846 (s), 824 (s), 607 (s).

HRMS (DART ${ }^{+}, \mathrm{m} / \mathrm{z}$ ): calculated for $\mathrm{C}_{12} \mathrm{H}_{24} \mathrm{NO}_{4}\left[\mathrm{M}+\mathrm{NH}_{4}\right]^{+}: 246.17037$, found: 246.16998 .

$[\alpha]_{D}^{20}=-126.6\left(\mathrm{c}=3.50 \mathrm{mg} / \mathrm{mL}, \mathrm{CHCl}_{3}\right)$

4h - 1,2,3,4-di-O-isopropylidene-6-O-(2,6-dideoxy- $\alpha$-D-erythro-hexopyranoside-3-ulosyl)- $\alpha$ D-galactopyranoside

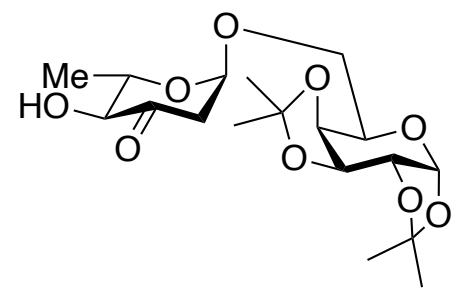

Prepared according to General Procedure D from 1,2,3,4-di-O-isopropylidene-6-O-(2-O-benzoyl$\alpha$-L-rhamnopyranosyl)- $\alpha$-D-galactopyranoside (2j) $(51.0 \mathrm{mg}, 0.1 \mathrm{mmol}$ ). Product (4h) was obtained as a light yellow oil (29.2 mg, 75\%) after flash column chromatography on silica (5-20\% acetone in dichloromethane).

$\mathbf{R}_{\boldsymbol{f}}=0.21$ (5\% acetone in dichloromethane) 
${ }^{1}$ H NMR (500 MHz, CDCl $\left.\mathbf{~}_{3}\right): \delta(\mathrm{ppm})=5.50(\mathrm{~d}, J=5.0 \mathrm{~Hz}, 1 \mathrm{H}$, gal-H1), $5.30(\mathrm{~d}, J=3.8 \mathrm{~Hz}, 1 \mathrm{H}$, rham-H1), 4.58 (dd, $J=7.9,2.4 \mathrm{~Hz}, 1 \mathrm{H}$, gal-H3), 4.29 (dd, $J=5.0,2.4 \mathrm{~Hz}, 1 \mathrm{H}$, gal-H2), 4.17 (dd, $J=8.0,1.9 \mathrm{~Hz}, 1 \mathrm{H}$, gal-H4), 3.94 (ddd, $J=6.3,6.3,1.8 \mathrm{~Hz}, 1 \mathrm{H}$, gal-H5), $3.92-3.87$ (m, 1H, rham-H5), $3.83(\mathrm{dd}, J=3.8,1.3 \mathrm{~Hz}, 1 \mathrm{H}$, rham-H4), $3.82-3.78(\mathrm{~m}, 1 \mathrm{H}$, gal-H6a), $3.58(\mathrm{dd}, J=$ 10.2, $6.7 \mathrm{~Hz}, 1 \mathrm{H}$, gal-H6b), $3.53(\mathrm{~d}, J=3.8 \mathrm{~Hz}, 1 \mathrm{H},-\mathrm{OH}), 2.80$ (ddd, $J=14.1,4.7,1.3 \mathrm{~Hz}, 1 \mathrm{H}$, rham-H2a), 2.71 (dd, $J=14.1,1.0 \mathrm{~Hz}, 1 \mathrm{H}$, rham-H2b), $1.52\left(\mathrm{~s}, 3 \mathrm{H},-\mathrm{CH}_{3}\right), 1.43\left(\mathrm{~s}, 3 \mathrm{H},-\mathrm{CH}_{3}\right)$, $1.42\left(\mathrm{~d}, J=6.1 \mathrm{~Hz}, 3 \mathrm{H}\right.$, rham- $\left.\mathrm{CH}_{3}\right), 1.32\left(\mathrm{~s}, 3 \mathrm{H},-\mathrm{CH}_{3}\right), 1.31\left(\mathrm{~s}, 3 \mathrm{H},-\mathrm{CH}_{3}\right)$.

${ }^{13}$ C NMR (126 MHz, $\left.\mathbf{C D C l}_{3}\right): \delta(\mathrm{ppm})=205.7,109.4,108.8,98.6,96.3,78.6,71.2,71.0,70.7$, $70.7,67.0,65.6,45.3,26.2,26.1,25.1,24.5,18.7$.

IR (neat, cm-1): 3464 (w), 2985 (w), 2929 (w), 1725 (s), 1378 (s), 1252 (s), 1211 (s), 1121 (s), 1063 (s), 1003 (s), 961 (s), 891 (s), 764 (s), 610 (s).

HRMS (DART ${ }^{+}, \mathrm{m} / \mathrm{z}$ ): calculated for $\mathrm{C}_{18} \mathrm{H}_{32} \mathrm{NO}_{9}\left[\mathrm{M}+\mathrm{NH}_{4}\right]^{+}$: 406.20716, found: 406.20805.

$[\boldsymbol{\alpha}]_{\boldsymbol{D}}^{20}=-101.9\left(\mathrm{c}=3.42 \mathrm{mg} / \mathrm{mL}, \mathrm{CHCl}_{3}\right)$

\section{4i - Methyl 4,6-dideoxy- $\alpha$-D-erythro-hexopyranoside-3-ulose}

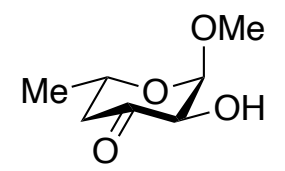

Prepared according to General Procedure D from methyl 4- $O$-trimethylacetyl- $\alpha$-Lrhamnopyranoside (2k) (56.5 mg, $0.2 \mathrm{mmol})$. Product (4i) was obtained as a yellow solid (20.7 $\mathrm{mg}, 65 \%$ ) after flash column chromatography on silica (5 to $10 \%$ acetone in dichloromethane).

The amount of remaining starting material in the reaction was found to be $0 \%$ by analysis of the crude ${ }^{1} \mathrm{H}$ NMR spectra relative to internal standard 1,3,5-trimethoxybenzene.

$\mathbf{R}_{\boldsymbol{f}}=0.62(10 \%$ acetone in dichloromethane)

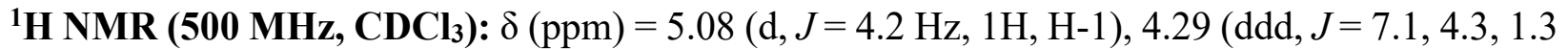
$\mathrm{Hz}, 1 \mathrm{H}, \mathrm{H}-2), 4.17-4.13$ (m, 1H, H-5), 3.41 (s, 3H, -OCH $), 3.26$ (d, J=7.1 Hz, 1H, -OH), 2.56 (dd, $J=13.7,2.8 \mathrm{~Hz}, 1 \mathrm{H}, \mathrm{H}-4), 2.41$ (ddd, $J=13.7,11.0,1.3 \mathrm{~Hz}, 1 \mathrm{H}, \mathrm{H}-4), 1.35$ (d, $J=6.2 \mathrm{~Hz}$, $\left.3 \mathrm{H},-\mathrm{CH}_{3}\right)$.

${ }^{13}$ C NMR (126 MHz, CDCl 3$): \delta(p p m)=204.8,102.3,75.7,66.4,55.7,47.9,21.5$.

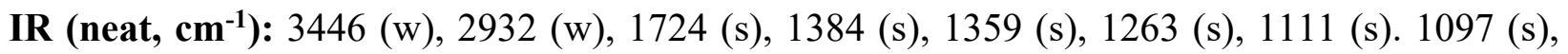
1025 (s), 977 (s), 901 (s), 786 (s), 643 (s).

HRMS (DART ${ }^{+}, \mathrm{m} / \mathrm{z}$ ): calculated for $\mathrm{C}_{7} \mathrm{H}_{16} \mathrm{NO}_{4}\left[\mathrm{M}+\mathrm{NH}_{4}\right]^{+}:$178.10738, found: 178.10648 .

$[\boldsymbol{\alpha}]_{\boldsymbol{D}}^{\mathbf{2 0}}=-153.0\left(5.65 \mathrm{mg} / \mathrm{mL}, \mathrm{CHCl}_{3}\right)$ 


\section{$\underline{2.5 \mathrm{mmol} \text { Scale Reaction }}$}

Methyl 4- $O$-trimethylacetyl- $\alpha$-L-rhamnopyranoside $(655.8 \mathrm{mg}, 2.5 \mathrm{mmol}, 1$ equiv.), $\left(\operatorname{Ir}\left[\mathrm{dF}\left(\mathrm{CF}_{3}\right) \mathrm{ppy}\right]_{2}(\mathrm{dtbpy})\right) \mathrm{PF}_{6}(28.0 \mathrm{mg}, 0.25 \mathrm{mmol}, 1 \mathrm{~mol} \%)$, quinuclidine (55.6 mg, $0.5 \mathrm{mmol}, 20$ mol\%), tetrabutylammonium 4-chlorobenzoate $(248.8 \mathrm{mg}, 0.625 \mathrm{mmol}, 25 \mathrm{~mol} \%)$, potassium bicarbonate (250.0 mg, $2.5 \mathrm{mmol}, 1$ equiv.) and a magnetic stir bar were added to a 9.5 dram vial. A rubber septum was used to seal the vial, which was then evacuated and backfilled with argon three times on a Schlenk line. Dry, degassed acetonitrile $(0.125 \mathrm{M})$ was added to the vial under a balloon of argon. The rubber septum was removed and quickly replaced with the vial cap which was sealed with Teflon tape and parafilm. The vial was placed 5 inches from three blue LED Kessil lamps and stirred at $1050 \mathrm{rpm}$ for 24 hours at $25^{\circ} \mathrm{C}$. After 24 hours the crude reaction was washed with saturated aqueous sodium bicarbonate. The organic layer was dried over $\mathrm{MgSO}_{4}$, filtered, and concentrated under reduced pressure. The crude material was purified by flash column chromatography on silica (5\% to $10 \%$ acetone in dichloromethane) to afford $4 \mathbf{i}$ as a yellow solid (240.8 mg, 60\%).

\section{4j - Methyl 2-deoxy- $\beta$-D-erythro-hexopyranoside-3-ulose}

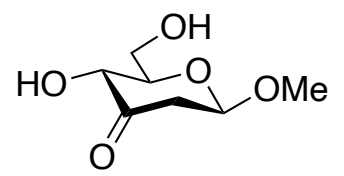

Prepared according to General Procedure D from methyl 2,6-di- $O$-trimethylacetyl- $\beta$-Dglucopyranoside (2l) $(72.5 \mathrm{mg}, 0.2 \mathrm{mmol})$. The yield of $\mathbf{4 j}$ was determined by ${ }^{1} \mathrm{H}$ NMR spectroscopic analysis with a quantitative internal standard from the crude material. The yield determined via ${ }^{1} \mathrm{H}$ NMR spectra of the crude mixture to be $27 \%$ (integration of the dd at $2.86 \mathrm{ppm}$ relative to internal standard 1,3,5-trimethoxybenzene).

The amount of remaining starting material in the reaction was found to be $67 \%$ by analysis of the crude ${ }^{1} \mathrm{H}$ NMR spectra relative to internal standard 1,3,5-trimethoxybenzene.

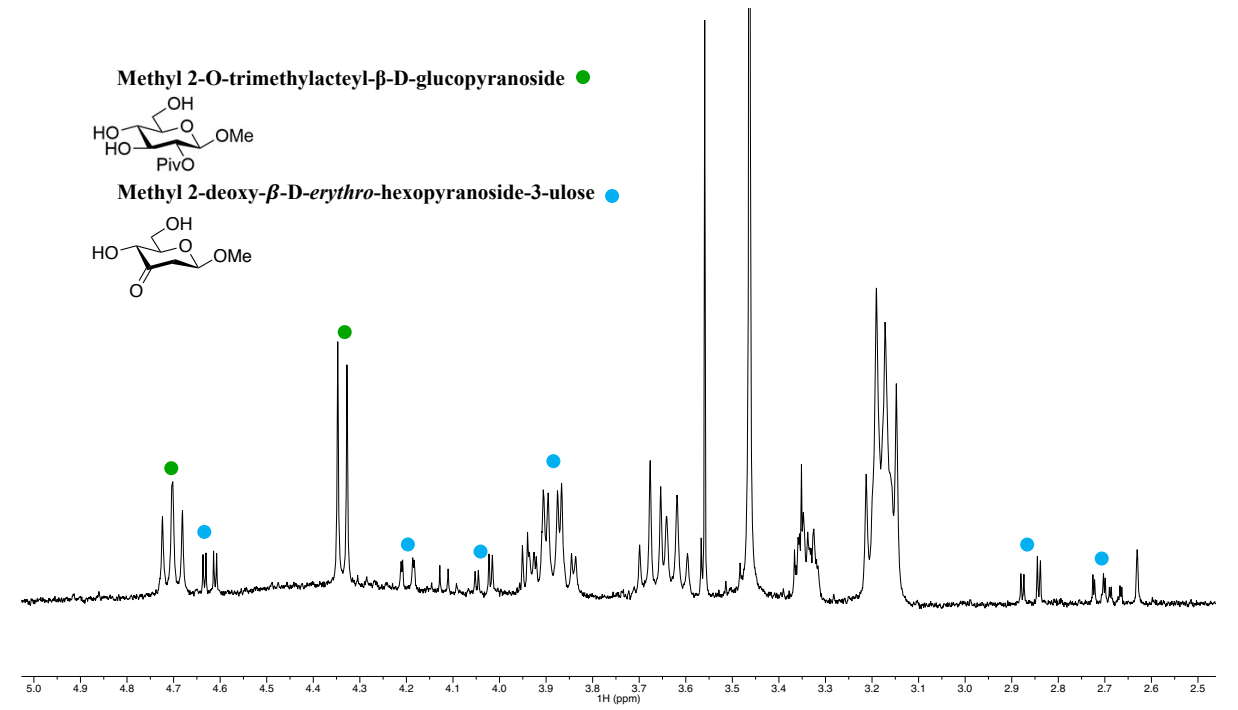

Crude ${ }^{1} \mathrm{H}$ NMR spectra showing select peaks of $4 \mathrm{j}$. 


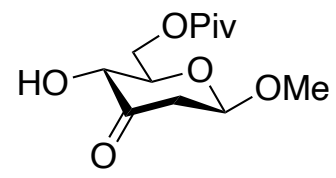

Prepared according to General Procedure D from methyl 2,6-di- $O$-trimethylacetyl- $\beta$-Dglucopyranoside (2m) $(72.5 \mathrm{mg}, 0.2 \mathrm{mmol})$. The yield of $\mathbf{4 k}$ was determined by ${ }^{1} \mathrm{H}$ NMR spectroscopic analysis with a quantitative internal standard from the crude material. The yield determined via ${ }^{1} \mathrm{H}$ NMR spectra of the crude mixture to be $36 \%$ (integration of the dd at $2.86 \mathrm{ppm}$ relative to internal standard 1,3,5-trimethoxybenzene).

The amount of remaining starting material in the reaction was found to be $42 \%$ by analysis of the crude ${ }^{1} \mathrm{H}$ NMR spectra relative to internal standard 1,3,5-trimethoxybenzene.

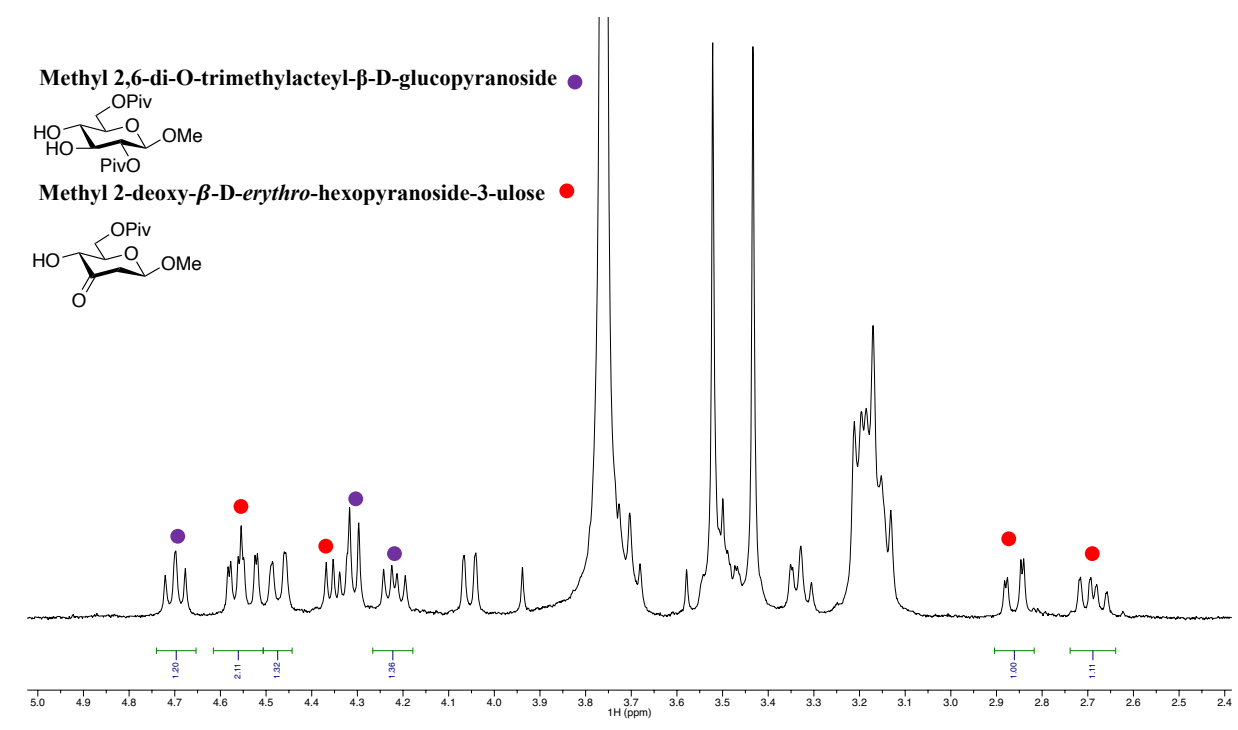

Crude ${ }^{1} \mathrm{H}$ NMR spectra showing select peaks of $4 \mathrm{k}$. 


\section{$\underline{\text { Derivatizations }}$}

\section{5a - Methyl- $\alpha$-L-digitoxose}

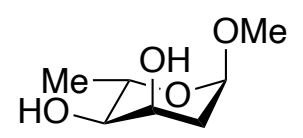

Product $4 \mathbf{f}$ (32.0 mg, $0.2 \mathrm{mmol}, 1$ equiv.) was added to a 2 dram vial equipped with a magnetic stir bar, dissolved in methanol $(2 \mathrm{~mL})$ after which $\mathrm{CeCl}_{3} \cdot 7 \mathrm{H}_{2} \mathrm{O}(37.2 \mathrm{mg}, 0.2 \mathrm{mmol}, 1$ equiv.) was added. Sodium borohydride ( $7.6 \mathrm{mg}, 0.1 \mathrm{mmol}, 0.5$ equiv.) was added to a separate 2 dram vial and dissolved in methanol $(2 \mathrm{~mL})$. The solution of sodium borohydride was added dropwise to the reaction vial and the reaction was allowed to stir at $23{ }^{\circ} \mathrm{C}$ until TLC revealed full consumption of starting material. Reaction mixture was concentrated under vacuum, dissolved in a $15 \%$ methanol in dichloromethane solution and filtered through a pad of silica to afford $\mathbf{5 a}$ as a white solid (25.3 mg, 78\%).

Spectral data were in agreement with those previously reported. ${ }^{17}$

${ }^{1}$ H NMR (500 MHz, CDCl $): \delta(\mathrm{ppm})=4.77(\mathrm{~d}, J=2.6 \mathrm{~Hz}, 1 \mathrm{H}), 3.96-3.92(\mathrm{~m}, 1 \mathrm{H}), 3.73-3.68$ $(\mathrm{m}, 1 \mathrm{H}), 3.42(\mathrm{~d}, 10.0 \mathrm{~Hz}, 1 \mathrm{H}), 3.379 \mathrm{~s}, 3 \mathrm{H}), 3.14(\mathrm{ddd}, J=10.3,10.3,3.3 \mathrm{~Hz}, 1 \mathrm{H}), 2.52(\mathrm{~d}, J=$ $10.5 \mathrm{~Hz}, 1 \mathrm{H}), 2.17$ (ddd, $J=14.7,3.2,1.2 \mathrm{~Hz}, 1 \mathrm{H}), 1.90$ (ddd, $J=14.7,3.3,3.3 \mathrm{~Hz}, 1 \mathrm{H}), 1.33$ (d, $=6.2 \mathrm{~Hz}, 3 \mathrm{H})$.

\section{5b - Methyl 3,4-di- $O$-acteyl- $\alpha$-L-olivose}

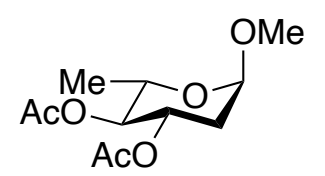

Synthesized according to adapted literature procedures. ${ }^{18}$

Product $4 \mathbf{f}$ ( $48.0 \mathrm{mg}, 0.3 \mathrm{mmol}, 1$ equiv.) was added to a 2 dram vial equipped with a magnetic stir bar and dissolved in anhydrous tetrahydrofuran $(2.2 \mathrm{~mL})$ under an atmosphere of argon gas and cooled to $-10^{\circ} \mathrm{C}$. Catecholborane $(0.1 \mathrm{~mL}, 0.9 \mathrm{mmol}, 3$ equiv. $)$ was added and the reaction mixture was stirred overnight. Reaction was quenched by addition of methanol $(1 \mathrm{~mL})$ and saturated aqueous sodium potassium tartrate $(1 \mathrm{~mL})$ and stirred at $23{ }^{\circ} \mathrm{C}$ for 2 hours, followed by removal of solvent under vacuum. The resulting residue was dissolved in pyridine $(6 \mathrm{~mL})$, acetic anhydride $(1.2 \mathrm{~mL})$ was added to the vial and the mixture was stirred overnight. Reaction was quenched with methanol and concentrated under vacuum. The crude material was dissolved in ethyl acetate and washed with $1 \mathrm{M}$ aqueous hydrochloric acid, saturated aqueous sodium bicarbonate, and brine. The organic layer was dried over $\mathrm{MgSO}_{4}$, filtered, and concentrated. The crude material was purified by flash column chromatography on silica (5\% to $10 \%$ acetone in dichloromethane) to afford $\mathbf{5 b}(30.3 \mathrm{mg}, 41 \%)$ as a white solid. 
Spectral data were in agreement with those previously reported. ${ }^{19}$

${ }^{1}$ H NMR (400 MHz, CDCl $): \delta(\mathrm{ppm})=5.26(\mathrm{q}, J=3.5 \mathrm{~Hz}, 1 \mathrm{H}), 4.68(\mathrm{~d}, J=2.6 \mathrm{~Hz}, 1 \mathrm{H}), 4.64$ $(\mathrm{dd}, J=9.5,3.2 \mathrm{~Hz}, 1 \mathrm{H}), 4.24-4.15(\mathrm{~m}, 1 \mathrm{H}), 3.35(\mathrm{~s}, 3 \mathrm{H}), 2.11(\mathrm{ddd}, J=15.1,3.7,1.7 \mathrm{~Hz}, 1 \mathrm{H})$, $2.08(\mathrm{~s}, 3 \mathrm{H}), 2.03$ (s, 3H), $2.00(\mathrm{dt}, J=15.1,3.9 \mathrm{~Hz}, 1 \mathrm{H}), 1.18(\mathrm{~d}, J=6.5 \mathrm{~Hz}, 3 \mathrm{H})$.

\section{5c - Methyl- $\alpha$-L-mycaroside}

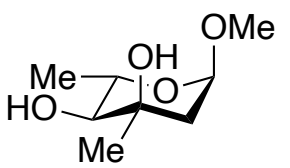

Prepared according to adapted literature procedures. ${ }^{20}$

Product $4 \mathbf{f}$ (48.0 mg, $0.3 \mathrm{mmol}, 1$ equiv.) was added to a 2 dram vial equipped with a magnetic stir bar. The vial was capped with a rubber septa and evacuated and backfilled with argon three times under Schlenk line. Anhydrous tetrahydrofuran $(6 \mathrm{~mL})$ was added and the reaction was cooled to $-78{ }^{\circ} \mathrm{C}$, followed by dropwise addition of methylmagnesium bromide $(0.58 \mathrm{~mL}, 1.74 \mathrm{mmol}, 5.8$ equiv.). The reaction was stirred at $-78{ }^{\circ} \mathrm{C}$ for 30 minutes, then at $0{ }^{\circ} \mathrm{C}$ for 10 minutes, then quenched by addition of saturated aqueous ammonium chloride. The mixture was extracted with ethyl acetate three times, then the combined organic layers were dried over sodium sulfate, filtered, and concentrated under vacuum. The crude material was purified by flash column chromatography on silica (20\% ethyl acetate in hexanes) to afford $\mathbf{5 c}(27.3 \mathrm{mg}, 52 \%)$ as a yellow oil.

Spectral data were in agreement with those previously reported. ${ }^{21}$

${ }^{1}$ H NMR (400 MHz, CDCl 3$): ~ \delta(p p m)=4.76(\mathrm{~d}, J=2.9,1 \mathrm{H}), 3.85(\mathrm{~s}, 1 \mathrm{H}), 3.63-3.56(\mathrm{~m}, 1 \mathrm{H})$, $3.37(\mathrm{~s}, 3 \mathrm{H}), 2.97(\mathrm{dd}, J=11.0,9.6 \mathrm{~Hz}, 1 \mathrm{H}), 2.24(\mathrm{~d}, J=11.1 \mathrm{~Hz}, 1 \mathrm{H}), 2.04(\mathrm{dd}, J=14.6,1.4 \mathrm{~Hz}$, $1 \mathrm{H}), 1.81(\mathrm{dd}, J=14.6,3.6 \mathrm{~Hz}, 1 \mathrm{H}), 1.33(\mathrm{~d}, J=6.2,3 \mathrm{H}), 1.23(\mathrm{~s}, 3 \mathrm{H})$. 


\section{Substrate Limitations}

Following substrates exhibited low conversion or trace product formation when subjected to General Procedure D/E.

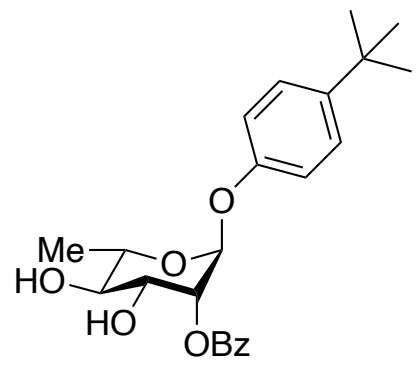

2n

trace product $<5 \%$ conversion

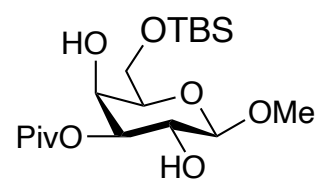

2p'

trace product $40 \%$ conversion

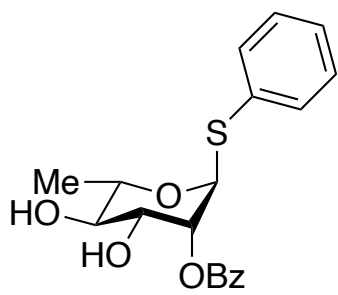

20

trace product $50 \%$ conversion

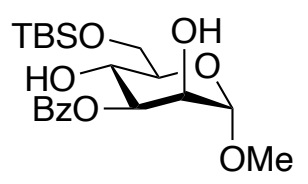

$2 q$

$5 \%$ product

$81 \%$ conversion

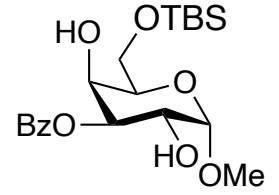

$2 p$

trace product

$43 \%$ conversion<smiles>CO[C@H]1OC(CO)[C@@H](O)[C@@H]1O</smiles>

$2 r$

trace product

$<5 \%$ conversion

\section{Preparation of Substrates 2n-2r}

\section{4-tert-butylphenyl- $\alpha$-L-rhamnopyranoside}<smiles>[M]C1C2COC1C(O)C(O)C(Oc1ccc(C(C)(C)C)cc1)C(O)C(O)O2</smiles>

Prepared according to previous literature procedures. ${ }^{22}$

Spectral data were in agreement with those previously reported. ${ }^{22}$

${ }^{1}$ H NMR (400 MHz, CD 3 OD): $\delta(\mathrm{ppm})=7.37-7.32(\mathrm{~m}, 2 \mathrm{H}), 7.03-6.98(\mathrm{~m}, 2 \mathrm{H}), 5.41(\mathrm{~d}, J=$ $1.8 \mathrm{~Hz}, 1 \mathrm{H}), 4.01$ (dd, $J=3.4,1.8 \mathrm{~Hz}, 1 \mathrm{H}), 3.97$ (dd, $J=9.5,3.4 \mathrm{~Hz}, 1 \mathrm{H}), 3.73-3.65(\mathrm{~m}, 1 \mathrm{H})$, $3.48(\mathrm{t}, J=9.5 \mathrm{~Hz}, 1 \mathrm{H}), 1.32(\mathrm{~s}, 9 \mathrm{H}), 1.26(\mathrm{~d}, J=6.2 \mathrm{~Hz}, 3 \mathrm{H})$. 
2n - 4-tert-butylphenyl-2- $O$-benzoyl- $\alpha$-L-rhamnopyranoside

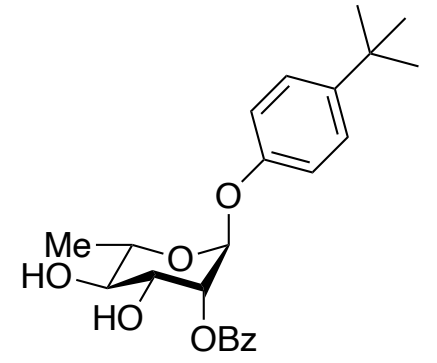

Prepared according General Procedure $\mathrm{C}$ from 4-tert-butylphenyl- $\alpha$-L-rhamnopyranoside and benzoic anhydride. $2 \mathrm{n}$ was isolated as a clear, colourless oil (102.6 mg, 18\%) after flash column chromatography on silica (40 to $50 \%$ ethyl acetate in hexanes).

$\boldsymbol{R}_{\mathbf{f}}=0.18(40 \%$ ethyl acetate in hexanes $)$

${ }^{1}$ H NMR (500 MHz, $\left.\mathbf{C D C l}_{3}\right): \delta(\mathrm{ppm})=8.12-8.06(\mathrm{~m}, 2 \mathrm{H}, \mathrm{Ar}-\mathrm{H}), 7.65-7.57$ (m, 1H, Ar-H), $7.51-7.44$ (m, 2H, Ar-H), $7.34-7.28(\mathrm{~m}, 2 \mathrm{H}, \mathrm{Ar}-\mathrm{H}), 7.04-6.98(\mathrm{~m}, 2 \mathrm{H}, \mathrm{Ar}-\mathrm{H}), 5.58$ (d, $J=1.7$ $\mathrm{Hz}, 1 \mathrm{H}, \mathrm{H}-1), 5.52$ (dd, $J=3.4,1.7 \mathrm{~Hz}, 1 \mathrm{H}, \mathrm{H}-2), 4.30$ (dd, $J=9.5,3.5 \mathrm{~Hz}, 1 \mathrm{H}, \mathrm{H}-3), 3.97-3.89$ $(\mathrm{m}, 1 \mathrm{H}, \mathrm{H}-5), 3.71(\mathrm{t}, J=9.5 \mathrm{~Hz}, 1 \mathrm{H}, \mathrm{H}-4), 1.37$ (d, $\left.J=6.2 \mathrm{~Hz}, 3 \mathrm{H},-\mathrm{CH}_{3}\right), 1.30\left(\mathrm{~s}, 9 \mathrm{H},-\mathrm{C}\left(\mathrm{CH}_{3}\right)_{3}\right)$.

${ }^{13}$ C NMR (125 MHz, $\left.\mathbf{C D C l}_{3}\right): \delta(\mathrm{ppm})=167.6,155.3,146.5,134.6,134.0,131.1,130.8,130.7$, $129.6,129.5,127.4,117.2,97.3,74.4,74.4,70.7,70.6,35.0,31.9,18.2$.

IR (neat, cm-1 ): 3409 (w), 2947 (w), 1709 (s), 1511 (s), 1267 (s), 1230 (s), 1112 (s), 1018 (s), 981 (s), 830 (s), 708 (s), 615 (s), 567 (s).

HRMS (DART ${ }^{+}, \mathrm{m} / \mathrm{z}$ ): calculated for $\mathrm{C}_{23} \mathrm{H}_{28} \mathrm{O}_{6}[\mathrm{M}+\mathrm{H}]^{+}:$401.19587; found: 401.19627 .

$[\boldsymbol{\alpha}]_{\boldsymbol{D}}^{20}=-16.2\left(16.80 \mathrm{mg} / \mathrm{mL}, \mathrm{CHCl}_{3}\right)$

Phenyl 1-thio- $\alpha$-L-rhamnopyranoside

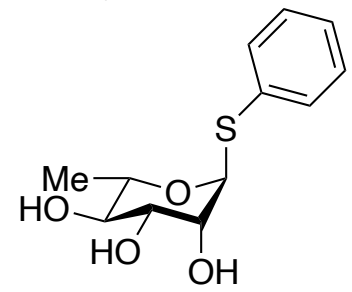

Prepared according to previous literature procedures. ${ }^{23}$

Spectral data were in agreement with those previously reported. ${ }^{23}$

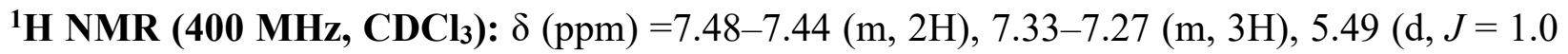
$\mathrm{Hz}, 1 \mathrm{H}), 4.21-4.13(\mathrm{~m}, 1 \mathrm{H}), 3.80(\mathrm{dd}, J=9.4,3.4 \mathrm{~Hz}, 1 \mathrm{H}), 3.55$ (t, $J=9.3 \mathrm{~Hz}, 1 \mathrm{H}), 1.33(\mathrm{~d}, J=$ $6.2 \mathrm{~Hz}, 3 \mathrm{H})$. 


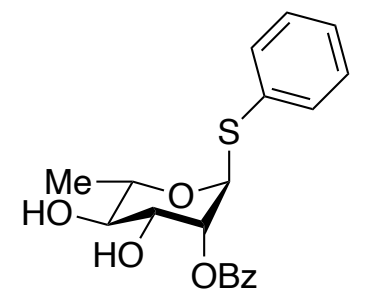

Prepared according to General Procedure C from phenyl 1-thio- $\alpha$-L-rhamnopyranoside and benzoic anhydride.

Spectral data were in agreement with those previously reported. ${ }^{24}$

${ }^{1}$ H NMR (500 MHz, CDCl $): \delta(\mathrm{ppm})=8.05-8.02(\mathrm{~m}, 2 \mathrm{H}), 7.60-7.56(\mathrm{~m}, 1 \mathrm{H}), 7.51-7.48(\mathrm{~m}$, 2H), 7.47-7.43 (m, 2H), 7.34-7.28 (m, 3H), $5.62(\mathrm{dd}, J=3.4,1.5 \mathrm{~Hz}, 1 \mathrm{H}), 5.58(\mathrm{~d}, J=1.0 \mathrm{~Hz}$, 1H), 4.29-4.22 (m, 1H), $4.08(\mathrm{dd}, J=9.4,3.4 \mathrm{~Hz}, 1 \mathrm{H}), 3.71(\mathrm{t}, J=9.4 \mathrm{~Hz}, 1 \mathrm{H}), 1.40$ (d, $6.2 \mathrm{~Hz}$, $3 \mathrm{H})$.

\section{2p - Methyl 3-O-benzoyl-6-O-(tert-butyldimethylsilyl)- $\alpha$-D-galactopyranoside}

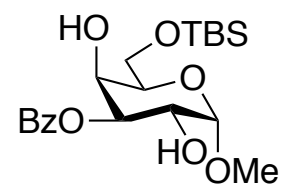

Synthesized according to previous literature procedures..$^{9}$

Spectral data were in agreement with those previously reported. ${ }^{9}$

${ }^{1}$ H NMR (400 MHz, CDCl 3$): \delta(\mathrm{ppm})=8.14-8.09(\mathrm{~m}, 2 \mathrm{H}), 7.60-7.54(\mathrm{~m}, 1 \mathrm{H}), 7.48-7.42(\mathrm{~m}$, 2H), $5.28(\mathrm{dd}, J=10.3,3.0 \mathrm{~Hz}, 1 \mathrm{H}), 4.91(\mathrm{~d}, J=3.9 \mathrm{~Hz}, 1 \mathrm{H}), 4.33(\mathrm{~d}, J=7.2 \mathrm{~Hz}, 1 \mathrm{H}), 4.29-4.21$ (m, 1H), 3.98-3.83 (m, 3H), $3.47(\mathrm{~s}, 3 \mathrm{H}), 0.91(\mathrm{~s}, 9 \mathrm{H}), 0.10(\mathrm{~s}, 3 \mathrm{H}), 0.10(\mathrm{~s}, 3 \mathrm{H})$. 


\section{2p' - Methyl 3-O-benzoyl-6-O-(tert-butyldimethylsilyl)- $\beta$-D-galactopyranoside}<smiles>COC1OC(O)C(O)C(O)C1OCc1ccccc1</smiles>

Synthesized according to previous literature procedures from methyl 6-O-(tertbutyldimethylsilyl)- $\beta$-D-galactopyranoside ( 1 equiv.) and trimethylacetyl chloride (1.2 equiv.). ${ }^{9}$

${ }^{1} \mathbf{H}$ NMR (400 MHz, $\left.\mathbf{C D C l}_{3}\right): \delta(\mathrm{ppm})=4.80(\mathrm{dd}, J=10.1,3.2 \mathrm{~Hz}, 1 \mathrm{H}, \mathrm{H} 3), 4.24(\mathrm{~d}, J=7.7 \mathrm{~Hz}$, $1 \mathrm{H}, \mathrm{H1}$ ), $4.12-4.08$ (m, 1H, H4), 3.92 (dd, $J=10.6,5.8 \mathrm{~Hz}, 1 \mathrm{H}, \mathrm{H} 6 \mathrm{a}), 3.89-3.83$ (m, 2H, H2, H6b), 3.55 (s, $3 \mathrm{H}, \mathrm{CH}_{3}$ ), 3.52 (ddd, $\left.J=5.8,4.9,1.0 \mathrm{~Hz}, 1 \mathrm{H}, \mathrm{H} 5\right), 1.25$ (s, 9H, $\left.\mathrm{CH}_{3}\right), 0.89$ (s, 9H, $\left.\mathrm{CH}_{3}\right), 0.09-0.07\left(\mathrm{~m}, 6 \mathrm{H}, \mathrm{CH}_{3}\right)$.

2q - Methyl 3-O-benzoyl-6-O-(tert-butyldimethylsilyl)- $\alpha$-D-mannopyranoside

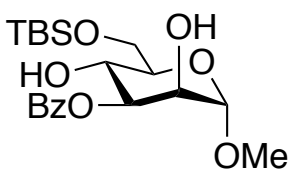

Synthesized according to previous literature procedures. ${ }^{9}$

Spectral data were in agreement with those previously reported. ${ }^{9}$

${ }^{1}$ H NMR (400 MHz, $\left.\mathbf{C D C l}_{3}\right): \delta(\mathrm{ppm})=8.12-8.08(\mathrm{~m}, 2 \mathrm{H}), 7.60-7.55(\mathrm{~m}, 1 \mathrm{H}), 7.48-7.42(\mathrm{~m}$, 2H), $5.35(\mathrm{dd}, J=9.7,3.2 \mathrm{~Hz}, 1 \mathrm{H}), 4.75(\mathrm{~d}, J=1.8 \mathrm{~Hz}, 1 \mathrm{H}), 4.17-4.08(\mathrm{~m}, 2 \mathrm{H}), 3.99-3.89(\mathrm{~m}$, 2H), 3.77-3.71 (m, 1H), 3.43 (s, 3H), $0.91(\mathrm{~s}, 9 \mathrm{H}), 0.11(\mathrm{~s}, 3 \mathrm{H}), 0.11(\mathrm{~s}, 3 \mathrm{H})$.

\section{2r - Methyl 2-O-trimethylacetyl-D-xylofuranoside}<smiles>CO[C@H]1O[C@H](CO)[C@@H](O)[C@H]1O</smiles>

Prepared according to adapted literature procedures..$^{25,5}$

Acetyl chloride (6.5 mmol, 1.3 equiv.) and methanol $(0.5 \mathrm{~mL})$ were added to a 2 dram vial equipped with a magnetic stir bar and stirred at $0{ }^{\circ} \mathrm{C}$ for 30 minutes. A solution of D-xylose $(5$ mmol, 1 equiv.) in methanol $(0.5 \mathrm{~mL})$ was added dropwise at $0{ }^{\circ} \mathrm{C}$, the reaction was then warmed to $23^{\circ} \mathrm{C}$ and stirred for 7 hours. The reaction was quenched with pyrdine $(1.5 \mathrm{~mL})$ and concentrated under vacuum. The crude material was purified by flash column chromatography on silica $(15 \%$ to $20 \%$ methanol in dichloromethane to afford methyl D-xylofuranoside as a white solid (587 $\mathrm{mg}$, $72 \%)$. 
Methyl D-xylofuranoside (3.6 mmol, 1 equiv.) and phenyl boronic acid (3.6 mmol, 1 equiv.) were dissolved in toluene $(18 \mathrm{~mL})$ and heated at $110{ }^{\circ} \mathrm{C}$ for $13 \mathrm{~h}$. Toluene was removed under reduced pressure and the resulting residue was azeotroped with toluene three times. The boronic ester was dissolved in pyridine $(7.2 \mathrm{~mL})$ and cooled to $0{ }^{\circ} \mathrm{C}$ with stirring. Trimethyl acetyl chloride (4.32 mmol, 1.2 equiv.) was added, and the reaction was warmed to $23^{\circ} \mathrm{C}$ and allowed to stir until TLC revealed full consumption of the starting material (ca. $2 \mathrm{~h}$ ). Reaction was dilute with toluene and filtered through a pad of Celite ${ }^{\circledR}$ followed by removal of the solvent under vacuum. The resulting residue was dissolved in ethyl acetate, added to a solution of 1.0 M sorbitol: $1 \mathrm{M}$ sodium carbonate aqueous solution and shaken for five minutes. The aqueous phase was extracted with ethyl acetate several times. The combined organic layers were dried over $\mathrm{MgSO}_{4}$, filtered, and concentrated under vacuum. The crude material was purified by flash column chromatography on silica $(10 \%$ to $30 \%$ acetone in dichloromethane) to afford methyl 2-O-trimethylacetyl-D-xylofuranoside (mixture of 2.5:1 $\alpha: \beta$ ) as a white solid (361 $\mathrm{mg}, 40 \%$ ).

Isolated as a 2.5:1 mixture of $\alpha$ and $\beta$ anomers.

Select peaks for methyl 2- $O$-trimethylacetyl- $\alpha$-D-xylofuranoside (major isomer)

${ }^{1} \mathbf{H}$ NMR (400 MHz, $\left.\mathbf{C D C l}_{3}\right): \delta(\mathrm{ppm})=5.10(\mathrm{~d}, J=4.5 \mathrm{~Hz}, 1 \mathrm{H}), 4.73(\mathrm{dd}, J=6.1 \mathrm{~Hz}, 4.4 \mathrm{~Hz}$, $1 \mathrm{H}), 4.55$ (dd, $J=7.2,7.2 \mathrm{~Hz}, 1 \mathrm{H}), 4.24-4.21$ (m, 1H), 3.36 (s, 3H), 1.22 (s, 9H).

Select peaks for methyl 2- $O$-trimethylacetyl- $\beta$-D-xylofuranoside (minor isomer)

${ }^{1} \mathbf{H}$ NMR (400 MHz, $\left.\mathbf{C D C l}_{3}\right): \delta(\mathrm{ppm})=4.96(\mathrm{~d}, J=2.2 \mathrm{~Hz}, 1 \mathrm{H}), 4.36(\mathrm{ddd}, J=10.6,10.6,4.9$, $1 \mathrm{H}), 3.44(\mathrm{~s}, 3 \mathrm{H}), 1.20(\mathrm{~s}, 9 \mathrm{H})$. 


\section{Computational Data}

DFT calculations were carried out using the Gaussian 16 suite of programs ${ }^{26}$ at the B97-D3/Def2TZVP level of theory. ${ }^{27,} 28$ Vibrational frequency calculations were carried out for each stationary point to ensure they were either an energy minimum (no imaginary frequencies) or a transition state (one imaginary frequency) on the potential energy surface. The imaginary frequency for each saddle point was visualized to verify that it corresponded to a transition state for H-atom transfer. The Intrinsic Reaction Coordinate (IRC) method was used to verify all transition states. Frequency calculations were carried out at $1 \mathrm{~atm}$ and $298.15 \mathrm{~K}$. Structures were visualized using Avogadro 1.2.0. Geometry optimizations and frequency calculations were carried out in the gas phase for calculated energies of all species except for proposed reaction intermediated and transition states depicted in Table S5 and Figure S1.

Geometry optimizations and frequency calculations were carried out in acetonitrile using the polarizable continuum model (PCM) for calculated energies of all proposed reaction intermediates and transition states. The calculated energies of these species (depicted in Figure S1) are listed in Table S12.

Single point energy calculations were carried out using the Gaussian 16 suite of programs ${ }^{26}$ at the M06-2X/aug-cc-pVTZ level of theory ${ }^{27,28}$ in acetonitrile using the polarizable continuum model (PCM) for calculated energies of all proposed reaction intermediates and transition states. The calculated energies of these species (depicted in Figure S2) are listed in Table S13.

Single point energy calculations were carried out using the ORCA 4.2.1 suite of programs at the $\omega \mathrm{B} 97 \mathrm{M}-\mathrm{V} / \mathrm{ma}-\mathrm{def} 2-\mathrm{TZVP}$ level of theory ${ }^{29.30}$ in acetonitrile using the conductor-like polarizable continuum model (CPCM) for calculated energies of all proposed reaction intermediates and transition states. The calculated energies of these species (depicted in Figure S3) are listed in Table S14.

\section{Calculated free energies of transition states of HAT}

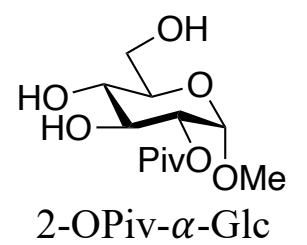

Table S4. Calculated gas-phase free energies of transition states for hydrogen atom transfer from 2-OPiv- $\alpha$-Glc to the quinuclidine radical cation. ${ }^{\text {a }}$

\begin{tabular}{|l|c|}
\hline Reaction & Gibbs free energy of transition state for HAT \\
\hline 2-OPiv- $\alpha$-Glc $(\mathrm{H} 1)+$ quinuclidine & -3.8 \\
\hline 2-OPiv- $\alpha$-Glc $(\mathrm{H} 2)+$ quinuclidine & -1.9 \\
\hline 2-OPiv- $\alpha$-Glc $(\mathrm{H} 3)+$ quinuclidine & -8.0 \\
\hline 2-OPiv- $\alpha$-Glc $(\mathrm{H} 4)+$ quinuclidine & -6.8 \\
\hline 2-OPiv- $\alpha$-Glc (H5) + quinuclidine & -2.5 \\
\hline
\end{tabular}

${ }^{\mathrm{a}} \mathrm{Gibbs}$ free energies in $\mathrm{kcal} / \mathrm{mol}$, calculated in gas phase. 


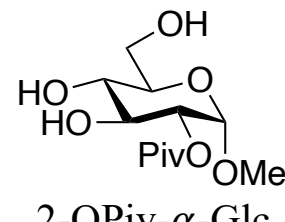

Table S5. Calculated free energies of transition states for hydrogen atom transfer from 2-OPiv- $\alpha$ Glc to the quinuclidine radical cation (PCM(acetonitrile)). ${ }^{\mathrm{a}}$

\begin{tabular}{|l|c|}
\hline Reaction & Gibbs free energy of transition state for HAT \\
\hline 2-OPiv- $\alpha$-Glc $(\mathrm{H} 1)+$ quinuclidine & - \\
\hline 2-OPiv- $\alpha$-Glc $(\mathrm{H} 2)+$ quinuclidine & 8.0 \\
\hline 2-OPiv- $\alpha$-Glc $(\mathrm{H} 3)+$ quinuclidine & 0.0 \\
\hline 2-OPiv- $\alpha$-Glc $(\mathrm{H} 4)+$ quinuclidine & 1.1 \\
\hline 2-OPiv- $\alpha$-Glc $(\mathrm{H} 5)+$ quinuclidine & 3.2 \\
\hline
\end{tabular}

${ }^{\mathrm{a}} \mathrm{Gibbs}$ free energies in $\mathrm{kcal} / \mathrm{mol}$ (PCM(acetonitrile)).

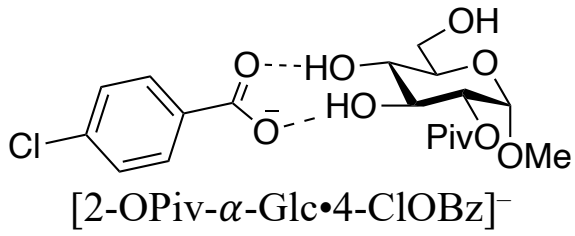

Table S6. Calculated gas-phase free energies of transition states for hydrogen atom transfer from 2-OPiv- $\alpha-\mathrm{Glc} \cdot 4-\mathrm{ClOBz}]^{-}$to the quinuclidine radical cation. ${ }^{\mathrm{a}}$

\begin{tabular}{|l|c|}
\hline Reaction & $\begin{array}{c}\text { Gibbs free energy of transition state for } \\
\text { HAT }\end{array}$ \\
\hline$[2 \mathrm{OPiv}-\alpha \mathrm{Glc} \bullet 4-\mathrm{ClOBz}]^{-}(\mathrm{H} 1)+$ quinuclidine & -63.2 \\
\hline$[2 \mathrm{OPiv}-\alpha \mathrm{Glc} \cdot 4-\mathrm{ClOBz}]^{-}(\mathrm{H} 2)+$ quinuclidine & - \\
\hline$[2 \mathrm{OPiv}-\alpha \mathrm{Glc} \cdot 4-\mathrm{ClOBz}]^{-}(\mathrm{H} 3)+$ quinuclidine & -78.5 \\
\hline$[2 \mathrm{OPiv}-\alpha \mathrm{Glc} \cdot 4-\mathrm{ClOBz}]^{-}(\mathrm{H} 4)+$ quinuclidine & -73.9 \\
\hline$[2 \mathrm{OPiv}-\alpha \mathrm{Glc} \cdot 4-\mathrm{ClOBz}]^{-}(\mathrm{H} 5)+$ quinuclidine & -68.5 \\
\hline
\end{tabular}

${ }^{\mathrm{a}} \mathrm{Gibbs}$ free energies in $\mathrm{kcal} / \mathrm{mol}$, calculated in gas phase. 


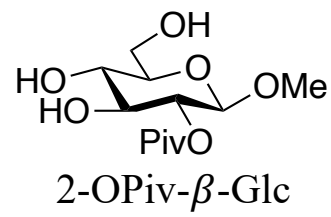

Table S7. Calculated gas-phase free energies of transition states for hydrogen atom transfer from 2-OPiv- $\beta$-Glc to the quinuclidine radical cation. ${ }^{\mathrm{a}}$

\begin{tabular}{|l|c|}
\hline Reaction & Gibbs free energy of transition state for HAT \\
\hline 2-OPiv- $\beta$-Glc $(\mathrm{H} 1)+$ quinuclidine & -4.9 \\
\hline 2-OPiv- $\beta$-Glc $(\mathrm{H} 2)+$ quinuclidine & -0.1 \\
\hline 2-OPiv- $\beta$-Glc $(\mathrm{H} 3)+$ quinuclidine & -5.2 \\
\hline 2-OPiv- $\beta$-Glc $(\mathrm{H} 4)+$ quinuclidine & -7.2 \\
\hline 2-OPiv- $\beta$-Glc $(\mathrm{H} 5)+$ quinuclidine & - \\
\hline
\end{tabular}

${ }^{a}$ Gibbs free energies in $\mathrm{kcal} / \mathrm{mol}$, calculated in gas phase.

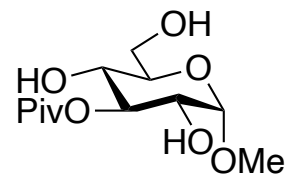

$3-$ OPiv- $\alpha$-Glc

Table S8. Calculated gas-phase free energies of transition states for hydrogen atom transfer from 3-OPiv-Glc to the quinuclidine radical cation. ${ }^{\text {a }}$

\begin{tabular}{|l|c|}
\hline Reaction & Gibbs free energy of transition state for HAT \\
\hline 3-OPiv- $\alpha$-Glc $(\mathrm{H} 1)+$ quinuclidine & -6.2 \\
\hline 3-OPiv- $\alpha$-Glc $(\mathrm{H} 2)+$ quinuclidine & -3.0 \\
\hline 3-OPiv- $\alpha$-Glc $(\mathrm{H} 3)+$ quinuclidine & -3.4 \\
\hline 3-OPiv- $\alpha$-Glc $(\mathrm{H} 4)+$ quinuclidine & -4.8 \\
\hline 3-OPiv- $\alpha$-Glc $(\mathrm{H} 5)+$ quinuclidine & -5.6 \\
\hline
\end{tabular}

${ }^{a}$ Gibbs free energies in $\mathrm{kcal} / \mathrm{mol}$, calculated in gas phase.

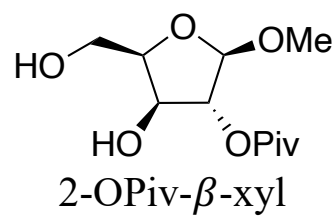

Table S9. Calculated gas-phase free energies of transition states for hydrogen atom transfer from 2-OPiv- $\beta$-xyl to the quinuclidine radical cation. ${ }^{\mathrm{a}}$

\begin{tabular}{|l|c|}
\hline Reaction & Gibbs free energy of transition state for HAT \\
\hline 2-OPiv- $\beta$-xyl $(\mathrm{H} 1)+$ quinuclidine & - \\
\hline 2- OPiv-- $\beta$-xyl $(\mathrm{H} 2)+$ quinuclidine & -3.3 \\
\hline 2- OPiv-- $\beta$-xyl $(\mathrm{H} 3)+$ quinuclidine & -5.4 \\
\hline 2- OPiv-- $\beta$-xyl $(\mathrm{H} 4)+$ quinuclidine & -7.1 \\
\hline 2- OPiv-- $\beta$-xyl $(\mathrm{H} 5)+$ quinuclidine & -4.8 \\
\hline
\end{tabular}

${ }^{\mathrm{a}}$ Gibbs free energies in $\mathrm{kcal} / \mathrm{mol}$, calculated in gas phase. 


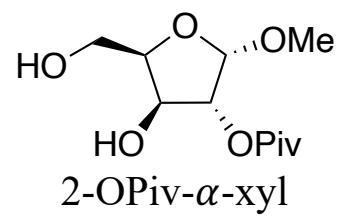

Table S10. Calculated gas-phase free energies of transition states for hydrogen atom transfer from 2 -OPiv- $\beta$-xyl to the quinuclidine radical cation. ${ }^{\mathrm{a}}$

\begin{tabular}{|l|c|}
\hline Reaction & Gibbs free energy of transition state for HAT \\
\hline 2- OPiv- $\alpha$-xyl (H1) + quinuclidine & - \\
\hline 2- OPiv- $\alpha$-xyl (H2) + quinuclidine & -0.2 \\
\hline 2- OPiv- $\alpha$-xyl (H3) + quinuclidine & -4.4 \\
\hline 2- OPiv- $\alpha$-xyl (H4) + quinuclidine & -8.2 \\
\hline 2- OPiv- $\alpha$-xyl (H5) + quinuclidine & -3.5 \\
\hline
\end{tabular}

${ }^{a}$ Gibbs free energies in $\mathrm{kcal} / \mathrm{mol}$, calculated in gas phase.

Effect of coordination of the carbonyl to the radical at C-3.

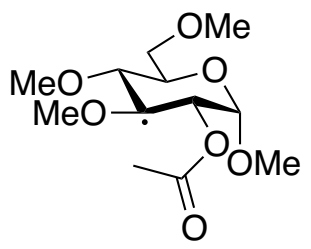

per-Me- $\alpha$-Glc_C3.

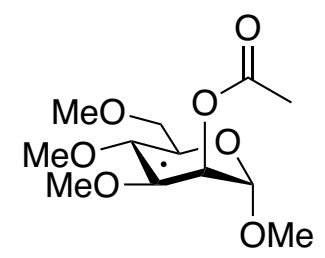

per-Me- $\alpha$-Man_C3.

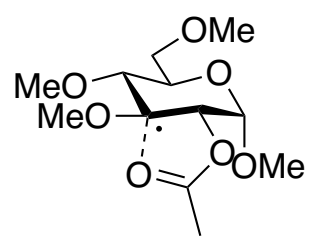

per-Me- $\alpha$-Glc_C3*_coord

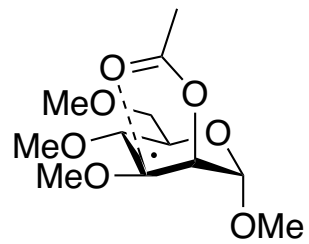

per-Me- $\alpha$-Man_C $3^{\circ}$ _coord

Table S11. Calculated energies of per-methylated 2- $O$-acylated- $\alpha$-gluco- and manno-pyranosides with a radical at $\mathrm{C}-3 .{ }^{\mathrm{a}}$

\begin{tabular}{|c|c|c|c|c|}
\hline Species & $\begin{array}{c}\text { Sum of } \\
\text { electronic and } \\
\text { zero-point } \\
\text { energies }\end{array}$ & $\begin{array}{c}\text { Sum of } \\
\text { electronic and } \\
\text { thermal } \\
\text { energies }\end{array}$ & $\begin{array}{c}\text { Sum of } \\
\text { electronic and } \\
\text { thermal } \\
\text { enthalpies }\end{array}$ & $\begin{array}{c}\text { Sum of } \\
\text { electronic } \\
\text { and thermal } \\
\text { free energies }\end{array}$ \\
\hline per-Me- $\boldsymbol{\alpha}$-Glc_C3 & -995.861089 & -995.838376 & -995.837432 & -995.916630 \\
\hline per-Me- $\boldsymbol{\alpha}-$ & -995.854743 & -995.832377 & -995.831433 & -995.908236 \\
\hline Glc_C3_coord & & & & \\
\hline per-Me- $\boldsymbol{\alpha}$-Man_C3 & -995.857846 & -995.835214 & -995.834270 & -995.912713 \\
\hline $\begin{array}{c}\text { per-Me- } \boldsymbol{\alpha} \text { - } \\
\text { Man_C3_coord }\end{array}$ & -995.859704 & -995.837086 & -995.836141 & -995.913602 \\
\hline
\end{tabular}

${ }^{a}$ Energies, enthalpies and free energies in $\mathrm{kcal} / \mathrm{mol}$, calculated in the gas phase 


\section{Proposed Reaction Pathway}

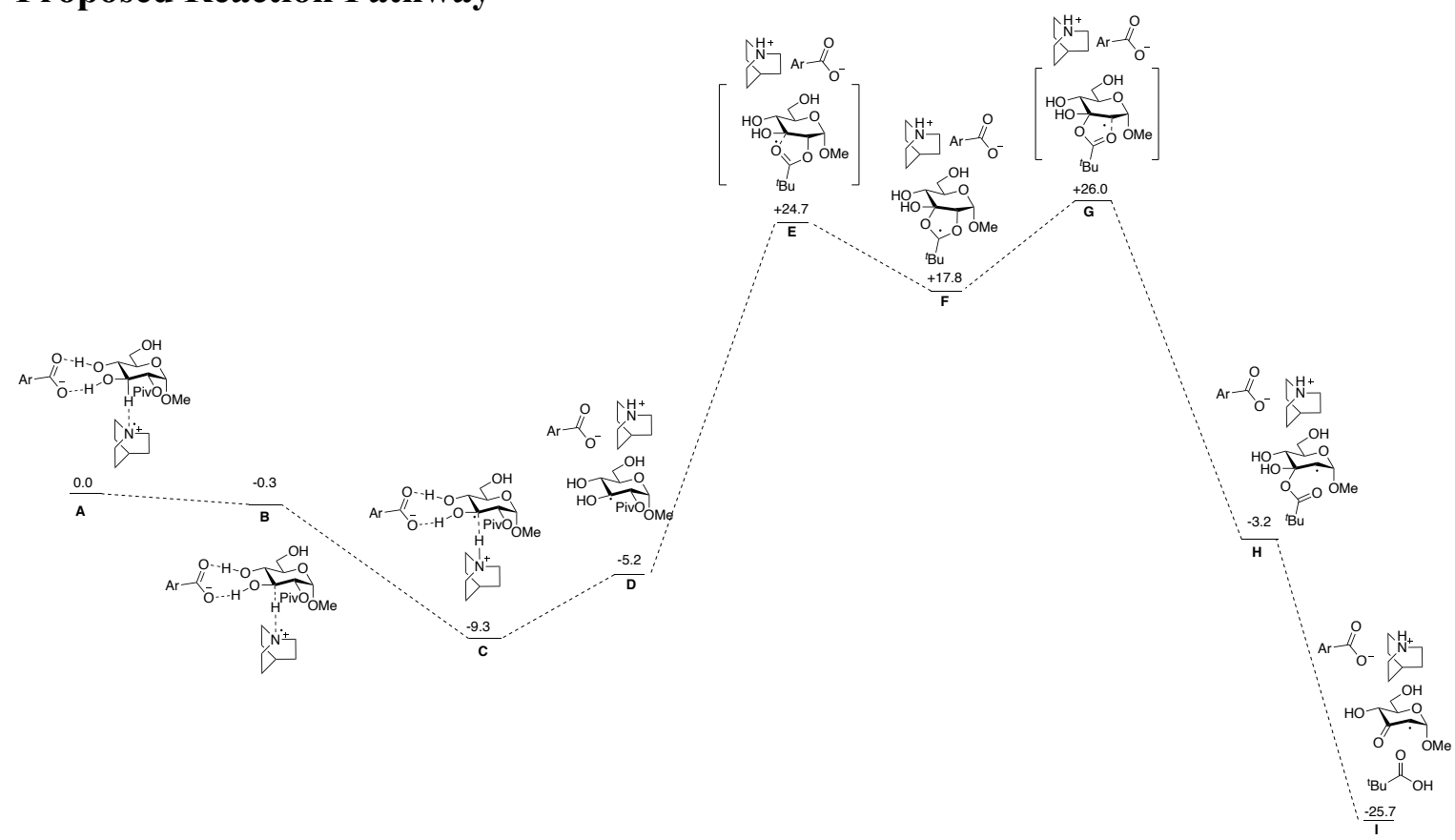

Figure S1. Calculated free energy profile of proposed intermediates and transition states for HAT and 1,2-acyloxy migration from a 2-O-pivoylated glucopyranoside (B97-D3/def2-TZVP, PCM (acetonitrile)).

Table S12. Calculated energies of reaction intermediates in Figure S1. ${ }^{\text {a }}$

\begin{tabular}{|c|c|c|c|c|}
\hline Species & $\begin{array}{c}\text { Sum of } \\
\text { electronic and } \\
\text { zero-point } \\
\text { energies }\end{array}$ & $\begin{array}{c}\text { Sum of } \\
\text { electronic and } \\
\text { thermal } \\
\text { energies }\end{array}$ & $\begin{array}{c}\text { Sum of } \\
\text { electronic and } \\
\text { thermal } \\
\text { enthalpies }\end{array}$ & $\begin{array}{c}\text { Sum of } \\
\text { electronic and } \\
\text { thermal free } \\
\text { energies }\end{array}$ \\
\hline HAT_PRC & -2205.2633 & -2205.223258 & -2205.222313 & -2205.342957 \\
\hline HAT_TS & -2205.266069 & -2205.226849 & -2205.225904 & -2205.343399 \\
\hline HAT_PostRC & 2205.279863 & -2205.240062 & -2205.239118 & -2205.359 \\
\hline OPiv-C2_rad-C3 & -995.923298 & -995.901628 & -995.900684 & -995.975 \\
\hline quin-H+_ArCO2- & -1209.327160 & -1209.310287 & -1209.309343 & -1209.375589 \\
\hline 1,2-mig_TS1 & -995.880132 & -995.859569 & -995.858624 & -995.9288 \\
\hline 1,2-mig_int & -995.890123 & -995.869653 & -995.868709 & -995.9383 \\
\hline 1,2-mig_TS2 & -995.876692 & -995.856191 & -995.855247 & -995.9248 \\
\hline OPiv-C3_rad-C2 & -995.922464 & -995.900743 & -995.899799 & -995.9731 \\
\hline C3-keto C2-rad & -649.111462 & -649.09902 & -649.098076 & -649.151 \\
\hline PivOH & -346.82486 & -346.816438 & -346.815494 & -346.8574 \\
\hline
\end{tabular}

${ }^{\mathrm{a}}$ Energies, enthalpies and free energies in $\mathrm{kcal} / \mathrm{mol}$ (PCM (acetonitrile)). 


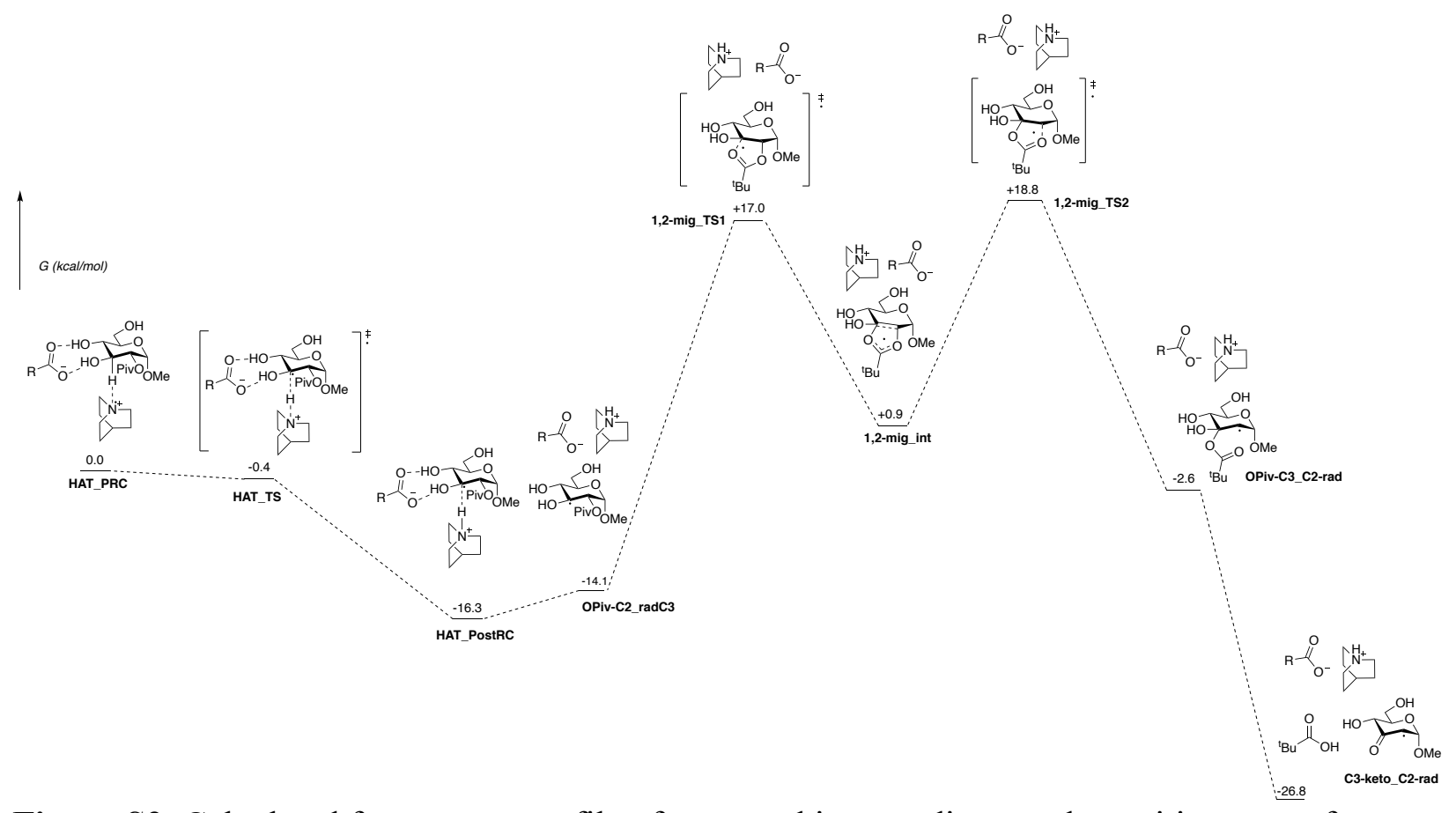

Figure S2. Calculated free energy profile of proposed intermediates and transition states for HAT and 1,2-acyloxy migration from a 2-O-pivoylated glucopyranoside (M06-2X/aug-cc-pVTZ, PCM (acetonitrile) single point energies, using the geometries and frequencies calculated at the B97-D3/def2-TZVP, PCM(acetonitrile) level of theory).

Table S13. Calculated energies of reaction intermediates in Figure S2. ${ }^{a}$

\begin{tabular}{|c|c|c|c|}
\hline Species & $\begin{array}{c}\text { Single point energies } \\
\text { (M06-2X) }\end{array}$ & $\begin{array}{c}\text { Free energy } \\
\text { correction (data } \\
\text { from Table S12) }\end{array}$ & $\begin{array}{c}\text { M06-2X free } \\
\text { energies }\end{array}$ \\
\hline HAT_PRC & -2206.183262 & 0.542038 & -2205.641224 \\
\hline HAT_TS & -2206.182836 & 0.54092 & -2205.641916 \\
\hline HAT_PostRC & -2206.212416 & 0.545269 & -2205.667147 \\
\hline OPiv-C2_rad-C3 & -996.4449682 & 0.274265 & -996.1707032 \\
\hline quin-H+_ArCO+ ${ }^{+}$ & -1209.740848 & 0.24779 & -1209.493058 \\
\hline 1,2-mig_TS1 & -996.3972467 & 0.27611 & -996.1211367 \\
\hline 1,2-mig_int & -996.425824 & 0.279161 & -996.146663 \\
\hline 1,2-mig_TS2 & -996.3945701 & 0.276299 & -996.1182711 \\
\hline OPiv-C3_rad-C2 & -996.425824 & 0.273535 & -996.152289 \\
\hline C3-keto_C2-rad & -649.4199971 & 0.139371 & -649.2806261 \\
\hline PivOH & -347.0208234 & 0.110516 & -346.9103074 \\
\hline
\end{tabular}

${ }^{\mathrm{a} E n e r g i e s, ~ e n t h a l p i e s ~ a n d ~ f r e e ~ e n e r g i e s ~ i n ~} \mathrm{kcal} / \mathrm{mol}$ (PCM (acetonitrile)). 


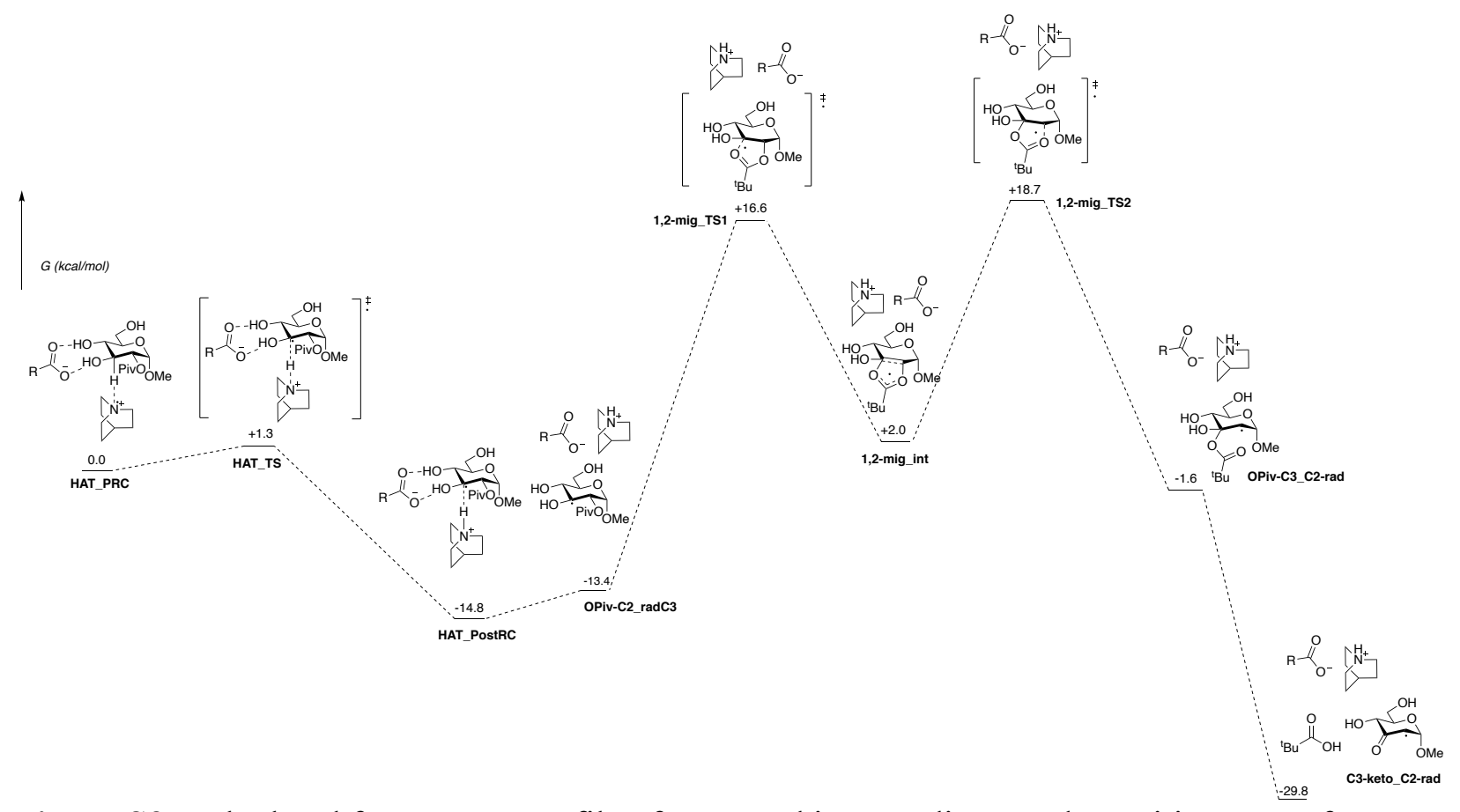

Figure S3. Calculated free energy profile of proposed intermediates and transition states for HAT and 1,2-acyloxy migration from a 2-O-pivoylated glucopyranoside $(\omega \mathrm{B} 97 \mathrm{M}-\mathrm{V} / \mathrm{ma}$-def2-TZVP, CPCM (acetonitrile) single point energies, using the geometries and frequencies calculated at the B97-D3/def2-TZVP, PCM(acetonitrile) level of theory).

Table S14. Calculated energies of reaction intermediates in Figure S3. ${ }^{\text {a }}$

\begin{tabular}{|c|c|c|c|}
\hline Species & $\begin{array}{c}\text { Single point energies } \\
\text { (wB97M-V) }\end{array}$ & $\begin{array}{c}\text { Free energy } \\
\text { correction(data } \\
\text { from Table S12) }\end{array}$ & $\begin{array}{c}\boldsymbol{\omega B 9 7 M - V} \text { free } \\
\text { energies }\end{array}$ \\
\hline HAT_PRC & -2206.258338 & 0.542038 & -2205.7163 \\
\hline HAT_TS & -2206.255118 & 0.54092 & -2205.714198 \\
\hline HAT_PostRC & -2206.285143 & 0.545269 & -2205.739874 \\
\hline OPiv-C2_rad-C3 & -996.5004876 & 0.274265 & -996.2262226 \\
\hline quin-H+_ArCO2- & -1209.759282 & 0.24779 & -1209.511492 \\
\hline 1,2-mig_TS1 & -996.4544627 & 0.27611 & -996.1783527 \\
\hline 1,2-mig_int & -996.4808604 & 0.279161 & -996.2016994 \\
\hline 1,2-mig_TS2 & -996.4512958 & 0.276299 & -996.1749968 \\
\hline OPiv-C3_rad-C2 & -996.4808604 & 0.273535 & -996.2073254 \\
\hline C3-keto_C2-rad & -649.4702592 & 0.139371 & -649.3308882 \\
\hline PivOH & -347.0319577 & 0.110516 & -346.9214417 \\
\hline
\end{tabular}

${ }^{\mathrm{a}}$ Energies, enthalpies and free energies in $\mathrm{kcal} / \mathrm{mol}$ (CPCM (acetonitrile)). 
Calculated energies and geometries.

Calculated free energies and geometries for HAT transition states.

[quinuclidine] $^{++}$

Energy (Hartree/particle): -328.948761853

$\begin{array}{lc}\text { Zero-point correction }= & 0.190863 \text { (Hartree/Particle) } \\ \text { Thermal correction to Energy }= & 0.197729 \\ \text { Thermal correction to Enthalpy= } & 0.198674 \\ \text { Thermal correction to Gibbs Free Energy= } & 0.158914 \\ \text { Sum of electronic and zero-point Energies }= & -328.757904 \\ \text { Sum of electronic and thermal Energies }= & -328.751037 \\ \text { Sum of electronic and thermal Enthalpies }= & -328.750093 \\ \text { Sum of electronic and thermal Free Energies }= & -328.789853\end{array}$

Number of imaginary frequencies: 0

\begin{tabular}{lrrr}
\multicolumn{4}{l}{ Geometry: } \\
$\mathrm{N}$ & 1.17345 & 0.00428 & -0.00794 \\
$\mathrm{C}$ & 0.81955 & 0.25548 & -1.38432 \\
$\mathrm{C}$ & 0.83823 & -1.31711 & 0.46515 \\
$\mathrm{C}$ & 0.83226 & 1.07095 & 0.90222 \\
$\mathrm{C}$ & -0.76904 & 1.09146 & 0.94874 \\
$\mathrm{H}$ & 1.22419 & 2.01557 & 0.52214 \\
$\mathrm{H}$ & 1.24867 & 0.85885 & 1.88818 \\
$\mathrm{C}$ & -0.78234 & 0.26723 & -1.41406 \\
$\mathrm{C}$ & -0.76292 & -1.36717 & 0.48093 \\
$\mathrm{H}$ & 1.24353 & -1.46043 & 1.46793 \\
$\mathrm{H}$ & 1.24539 & -2.06496 & -0.21708 \\
$\mathrm{C}$ & -1.27828 & -0.00488 & 0.00884 \\
$\mathrm{H}$ & -1.11198 & 2.08129 & 0.63809 \\
$\mathrm{H}$ & -1.08909 & 0.91988 & 1.97929 \\
$\mathrm{H}$ & -1.12132 & -0.50051 & -2.11375 \\
$\mathrm{H}$ & -1.11624 & 1.24182 & -1.77812 \\
$\mathrm{H}$ & -1.09227 & -1.59335 & 1.49791 \\
$\mathrm{H}$ & -1.09201 & -2.17353 & -0.17888 \\
$\mathrm{H}$ & -2.37662 & -0.00911 & 0.01648 \\
$\mathrm{H}$ & 1.22266 & 1.22017 & -1.69635 \\
$\mathrm{H}$ & 1.21619 & -0.54136 & -2.01527
\end{tabular}

\section{[2-OPiv- $\alpha$-Glc]}

Energy (Hartree/particle): -996.892644643 
Zero-point correction $=$

Thermal correction to Energy=

Thermal correction to Enthalpy=

Thermal correction to Gibbs Free Energy=

Sum of electronic and zero-point Energies $=$

Sum of electronic and thermal Energies=

Sum of electronic and thermal Enthalpies=

Sum of electronic and thermal Free Energies=
0.339655 (Hartree/Particle)

0.361296

0.362240

0.288371

$-996.552989$

$-996.531348$

$-996.530404$

$-996.604274$

Number of imaginary frequencies: 0

\section{Geometry:}

$\begin{array}{lrrr}\text { C } & -0.48786 & 1.12969 & 0.39560 \\ \mathrm{C} & 0.03709 & -0.31627 & 0.42709 \\ \mathrm{C} & -0.86247 & -1.25160 & -0.36270 \\ \mathrm{O} & -0.40742 & -2.58825 & -0.16928 \\ \mathrm{C} & -2.30671 & -1.09537 & 0.11147 \\ \mathrm{C} & -2.74175 & 0.37504 & 0.08119 \\ \mathrm{C} & -4.11650 & 0.60479 & 0.71193 \\ \mathrm{O} & -5.16018 & -0.11652 & 0.03526 \\ \mathrm{O} & -1.83556 & 1.17293 & 0.85769 \\ \mathrm{O} & -3.10350 & -1.91798 & -0.74270 \\ \mathrm{O} & 1.35766 & -0.39799 & -0.14084 \\ \mathrm{O} & -0.34503 & 1.62932 & -0.90889 \\ \mathrm{H} & -2.75027 & 0.71856 & -0.96597 \\ \mathrm{H} & 0.06428 & 1.74886 & 1.11321 \\ \mathrm{H} & 0.07944 & -0.63150 & 1.47413 \\ \mathrm{H} & -0.81756 & -0.97974 & -1.42854 \\ \mathrm{H} & -2.36509 & -1.45209 & 1.15462 \\ \mathrm{C} & -0.51425 & 3.04359 & -0.99616 \\ \mathrm{C} & 2.39848 & -0.02072 & 0.64703 \\ \mathrm{H} & -4.11381 & 0.23154 & 1.74090 \\ \mathrm{H} & -4.33118 & 1.68174 & 0.73997 \\ \mathrm{H} & -4.03023 & -1.74270 & -0.50654 \\ \mathrm{H} & -1.08092 & -3.15940 & -0.56692 \\ \mathrm{H} & -5.29400 & 0.29645 & -0.82909 \\ \mathrm{O} & 2.26432 & 0.38941 & 1.77975 \\ \mathrm{C} & 3.72839 & -0.17447 & -0.10062 \\ \mathrm{C} & 4.87815 & 0.21502 & 0.83653 \\ \mathrm{C} & 3.70827 & 0.76048 & -1.32885 \\ \mathrm{C} & 3.88962 & -1.63880 & -0.55756 \\ \mathrm{H} & -0.32713 & 3.31671 & -2.03731 \\ \mathrm{H} & 0.20604 & 3.56301 & -0.34653 \\ \mathrm{H} & -1.53123 & 3.34558 & -0.71308\end{array}$




$\begin{array}{lrrr}\mathrm{H} & 4.84832 & -1.75364 & -1.07614 \\ \mathrm{H} & 3.08578 & -1.93511 & -1.23545 \\ \mathrm{H} & 3.88304 & -2.31956 & 0.30070 \\ \mathrm{H} & 5.83134 & 0.11132 & 0.30649 \\ \mathrm{H} & 4.90090 & -0.42686 & 1.72197 \\ \mathrm{H} & 4.77923 & 1.24983 & 1.17678 \\ \mathrm{H} & 4.66337 & 0.68247 & -1.86054 \\ \mathrm{H} & 3.57313 & 1.80457 & -1.02430 \\ \mathrm{H} & 2.90139 & 0.49445 & -2.01609\end{array}$

\section{[2-OPiv- $\alpha$-Glc(H1)•quinuclidine $]^{++}($transition state for HAT)}

Energy (Hartree/particle): -1325.86493782

$\begin{array}{lc}\text { Zero-point correction }= & 0.527471 \text { (Hartree/Particle) } \\ \text { Thermal correction to Energy= } & 0.557560 \\ \text { Thermal correction to Enthalpy= } & 0.558504 \\ \text { Thermal correction to Gibbs Free Energy= } & 0.464732 \\ \text { Sum of electronic and zero-point Energies }= & -1325.337467 \\ \text { Sum of electronic and thermal Energies }= & -1325.307378 \\ \text { Sum of electronic and thermal Enthalpies }= & -1325.306434 \\ \text { Sum of electronic and thermal Free Energies }= & -1325.400206\end{array}$

Number of imaginary frequencies: $1,-1020.7599$

\begin{tabular}{lrrr}
\multicolumn{4}{l}{ Geometry: } \\
C & -0.75147 & -0.29663 & 0.60245 \\
$\mathrm{C}$ & -0.83873 & 0.94438 & -0.29851 \\
$\mathrm{C}$ & -2.28743 & 1.44580 & -0.33124 \\
$\mathrm{O}$ & -2.34732 & 2.48395 & -1.28807 \\
$\mathrm{C}$ & -3.24291 & 0.30468 & -0.69174 \\
$\mathrm{C}$ & -3.04849 & -0.90045 & 0.23522 \\
$\mathrm{C}$ & -3.79013 & -2.15356 & -0.21945 \\
$\mathrm{O}$ & -5.18437 & -1.84058 & -0.23612 \\
$\mathrm{O}$ & -1.63457 & -1.29117 & 0.23106 \\
$\mathrm{O}$ & -4.54706 & 0.85160 & -0.58073 \\
$\mathrm{O}$ & -0.02163 & 2.00150 & 0.19519 \\
$\mathrm{O}$ & -0.75062 & 0.06728 & 1.92682 \\
$\mathrm{H}$ & -3.35127 & -0.62900 & 1.25491 \\
$\mathrm{H}$ & 0.37471 & -0.88127 & 0.33574 \\
$\mathrm{H}$ & -0.52525 & 0.66802 & -1.30895 \\
$\mathrm{H}$ & -2.54988 & 1.81571 & 0.67309 \\
$\mathrm{H}$ & -3.02938 & -0.01183 & -1.72822 \\
$\mathrm{C}$ & -0.88983 & -0.95771 & 2.92950 \\
$\mathrm{C}$ & 1.19600 & 2.20283 & -0.39045
\end{tabular}




\begin{tabular}{|c|c|c|c|}
\hline $\mathrm{H}$ & -3.42905 & -2.43493 & -1.22022 \\
\hline $\mathrm{H}$ & -3.57473 & -2.97767 & 0.47619 \\
\hline $\mathrm{H}$ & -5.18141 & 0.12193 & -0.68580 \\
\hline $\mathrm{H}$ & -3.28487 & 2.69493 & -1.41813 \\
\hline $\mathrm{H}$ & -5.67203 & -2.59054 & -0.60053 \\
\hline $\mathrm{O}$ & 1.64437 & 1.45115 & -1.23211 \\
\hline $\mathrm{C}$ & 1.87652 & 3.45126 & 0.16043 \\
\hline $\mathrm{C}$ & 2.01538 & 3.31366 & 1.69225 \\
\hline $\mathrm{C}$ & 1.00075 & 4.67730 & -0.18317 \\
\hline $\mathrm{C}$ & 3.26157 & 3.59401 & -0.48411 \\
\hline $\mathrm{H}$ & 4.23012 & -3.85057 & -0.89346 \\
\hline $\mathrm{C}$ & 3.39133 & -3.20241 & -0.62490 \\
\hline $\mathrm{H}$ & 1.85814 & -4.74294 & -0.61547 \\
\hline $\mathrm{H}$ & 3.51279 & -1.87389 & -2.34137 \\
\hline $\mathrm{H}$ & 4.19287 & -2.51629 & 1.27585 \\
\hline $\mathrm{H}$ & 2.54413 & -3.32091 & -2.63065 \\
\hline $\mathrm{H}$ & 2.70981 & -4.58291 & 0.92163 \\
\hline $\mathrm{H}$ & 4.71750 & -1.55177 & -0.10624 \\
\hline $\mathrm{C}$ & 2.29649 & -4.02024 & 0.07955 \\
\hline $\mathrm{C}$ & 2.79204 & -2.55940 & -1.88560 \\
\hline $\mathrm{C}$ & 3.86669 & -2.08872 & 0.32253 \\
\hline $\mathrm{C}$ & 1.20548 & -3.03953 & 0.59649 \\
\hline $\mathrm{C}$ & 1.50377 & -1.78590 & -1.48251 \\
\hline $\mathrm{C}$ & 2.69095 & -1.09409 & 0.54767 \\
\hline $\mathrm{N}$ & 1.45091 & -1.70216 & 0.00095 \\
\hline $\mathrm{H}$ & 0.19622 & -3.35010 & 0.31833 \\
\hline $\mathrm{H}$ & 1.49698 & -0.76674 & -1.86898 \\
\hline $\mathrm{H}$ & 2.52378 & -0.88421 & 1.60743 \\
\hline $\mathrm{H}$ & 0.59517 & -2.30065 & -1.80393 \\
\hline $\mathrm{H}$ & 1.24557 & -2.92438 & 1.68208 \\
\hline $\mathrm{H}$ & 2.84204 & -0.15159 & 0.02175 \\
\hline $\mathrm{H}$ & -1.34633 & -0.47336 & 3.79380 \\
\hline $\mathrm{H}$ & 0.10467 & -1.32699 & 3.20557 \\
\hline $\mathrm{H}$ & -1.51327 & -1.78234 & 2.57796 \\
\hline $\mathrm{H}$ & 1.04047 & 3.23670 & 2.17909 \\
\hline $\mathrm{H}$ & 2.53107 & 4.19572 & 2.08453 \\
\hline $\mathrm{H}$ & 2.61088 & 2.43197 & 1.95785 \\
\hline $\mathrm{H}$ & 3.18819 & 3.67613 & -1.57171 \\
\hline $\mathrm{H}$ & 3.90169 & 2.73697 & -0.25142 \\
\hline $\mathrm{H}$ & 3.74647 & 4.49671 & -0.10039 \\
\hline $\mathrm{H}$ & 0.87157 & 4.77683 & -1.26569 \\
\hline $\mathrm{H}$ & 1.49493 & 5.58154 & 0.18621 \\
\hline $\mathrm{H}$ & 0.01299 & 4.60520 & 0.27769 \\
\hline
\end{tabular}




\section{[2-OPiv- $\alpha$-Glc(H2)•quinuclidine $]^{++}($transition state for HAT)}

Energy (Hartree/particle): -1325.86274115

$\begin{array}{lc}\text { Zero-point correction }= & 0.527491 \text { (Hartree/Particle) } \\ \text { Thermal correction to Energy= } & 0.557432 \\ \text { Thermal correction to Enthalpy= } & 0.558376 \\ \text { Thermal correction to Gibbs Free Energy= } & 0.465583 \\ \text { Sum of electronic and zero-point Energies }= & -1325.335251 \\ \text { Sum of electronic and thermal Energies }= & -1325.305310 \\ \text { Sum of electronic and thermal Enthalpies }= & -1325.304365 \\ \text { Sum of electronic and thermal Free Energies }= & -1325.397158\end{array}$

Number of imaginary frequencies: 1, -1236.1025

\section{Geometry:}

$\begin{array}{lrrr}\mathrm{C} & -0.68747 & -1.13524 & -1.08888 \\ \mathrm{C} & -0.14956 & -0.59879 & 0.25215 \\ \mathrm{C} & -1.12926 & -0.66059 & 1.40836 \\ \mathrm{O} & -0.65165 & 0.18105 & 2.45563 \\ \mathrm{C} & -2.56062 & -0.30142 & 1.00803 \\ \mathrm{C} & -2.94786 & -1.00891 & -0.29516 \\ \mathrm{C} & -4.30726 & -0.57844 & -0.83594 \\ \mathrm{O} & -5.28652 & -0.91475 & 0.15451 \\ \mathrm{O} & -1.99633 & -0.63610 & -1.31190 \\ \mathrm{O} & -3.35887 & -0.66382 & 2.12210 \\ \mathrm{O} & 1.06658 & -1.11698 & 0.68602 \\ \mathrm{O} & -0.60555 & -2.52851 & -1.02495 \\ \mathrm{H} & -2.93892 & -2.09560 & -0.14204 \\ \mathrm{H} & -0.10646 & -0.74891 & -1.93222 \\ \mathrm{H} & 0.05087 & 0.67118 & 0.02831 \\ \mathrm{H} & -1.14358 & -1.71239 & 1.74463 \\ \mathrm{H} & -2.61946 & 0.78553 & 0.82720 \\ \mathrm{C} & -0.72954 & -3.17328 & -2.30557 \\ \mathrm{C} & 2.15212 & -1.23617 & -0.17799 \\ \mathrm{H} & -4.29366 & 0.50522 & -1.03040 \\ \mathrm{H} & -4.50086 & -1.10059 & -1.78255 \\ \mathrm{H} & -4.28430 & -0.68936 & 1.81810 \\ \mathrm{H} & -1.26951 & 0.07721 & 3.19500 \\ \mathrm{H} & -6.15776 & -0.63295 & -0.15201 \\ \mathrm{O} & 2.19280 & -0.63773 & -1.22529 \\ \mathrm{C} & 3.21696 & -2.14372 & 0.41468 \\ \mathrm{C} & 4.39376 & -2.23395 & -0.56590 \\ \mathrm{C} & 2.60450 & -3.54311 & 0.64767 \\ \mathrm{C} & 3.68673 & -1.54239 & 1.75983 \\ \mathrm{H} & 1.36090 & 5.45359 & -0.51708\end{array}$




$\begin{array}{lrrr}\mathrm{C} & 1.06490 & 4.40682 & -0.40332 \\ \mathrm{H} & -0.53064 & 4.89971 & 0.99661 \\ \mathrm{H} & 3.02263 & 3.83533 & 0.36604 \\ \mathrm{H} & 0.62474 & 4.19998 & -2.52787 \\ \mathrm{H} & 1.81987 & 4.15308 & 1.61847 \\ \mathrm{H} & -1.06669 & 4.72907 & -0.67670 \\ \mathrm{H} & 2.23234 & 3.63563 & -2.06705 \\ \mathrm{C} & -0.39029 & 4.31999 & 0.07986 \\ \mathrm{C} & 1.96787 & 3.71256 & 0.62791 \\ \mathrm{C} & 1.18609 & 3.67548 & -1.74941 \\ \mathrm{C} & -0.73507 & 2.82679 & 0.35595 \\ \mathrm{C} & 1.61628 & 2.19687 & 0.65728 \\ \mathrm{C} & 0.62499 & 2.23066 & -1.58924 \\ \mathrm{~N} & 0.38185 & 1.98657 & -0.14424 \\ \mathrm{H} & -0.85136 & 2.60637 & 1.41763 \\ \mathrm{H} & 2.39797 & 1.58913 & 0.20062 \\ \mathrm{H} & -0.33084 & 2.09867 & -2.10155 \\ \mathrm{H} & 1.42078 & 1.82668 & 1.66490 \\ \mathrm{H} & -1.64037 & 2.51471 & -0.16849 \\ \mathrm{H} & 1.32339 & 1.47151 & -1.94025 \\ \mathrm{H} & -0.61196 & -4.24199 & -2.11992 \\ \mathrm{H} & 0.05892 & -2.82489 & -2.98603 \\ \mathrm{H} & -1.71247 & -2.97915 & -2.74913 \\ \mathrm{H} & 4.10789 & -0.54058 & 1.61913 \\ \mathrm{H} & 4.47274 & -2.18076 & 2.17466 \\ \mathrm{H} & 2.86996 & -1.48393 & 2.48309 \\ \mathrm{H} & 4.07965 & -2.64892 & -1.52773 \\ \mathrm{H} & 5.16358 & -2.88640 & -0.14359 \\ \mathrm{H} & 4.83752 & -1.25128 & -0.74961 \\ \mathrm{H} & 2.23473 & -3.97229 & -0.28885 \\ \mathrm{H} & 1.77964 & -3.50773 & 1.36325 \\ \mathrm{H} & 3.38039 & -4.20507 & 1.04439 \\ & & & \\ & & & \end{array}$

\section{[2-OPiv- $\alpha$-Glc(H3)•quinuclidine $]^{++}($transition state for HAT)}

Energy (Hartree/particle): -1325.87383911

$\begin{array}{lc}\text { Zero-point correction }= & 0.528489 \text { (Hartree/Particle) } \\ \text { Thermal correction to Energy= } & 0.558062 \\ \text { Thermal correction to Enthalpy= } & 0.559006 \\ \text { Thermal correction to Gibbs Free Energy= } & 0.467040 \\ \text { Sum of electronic and zero-point Energies }= & -1325.345350 \\ \text { Sum of electronic and thermal Energies }= & -1325.315777 \\ \text { Sum of electronic and thermal Enthalpies }= & -1325.314833 \\ \text { Sum of electronic and thermal Free Energies }= & -1325.406799\end{array}$


Number of imaginary frequencies: $1,-951.0240$

$\begin{array}{lrrr}\text { Geometry: } & & \\ \text { C } & 0.28094 & -1.93604 & 0.95105 \\ \text { C } & 0.72645 & -1.41304 & -0.42736 \\ \mathrm{C} & -0.42777 & -0.79202 & -1.17804 \\ \mathrm{O} & -0.06526 & -0.37046 & -2.44518 \\ \mathrm{C} & -1.68659 & -1.64565 & -1.16006 \\ \mathrm{C} & -1.99734 & -2.17122 & 0.24979 \\ \mathrm{C} & -3.08186 & -3.24426 & 0.23490 \\ \mathrm{O} & -4.26032 & -2.65163 & -0.33704 \\ \mathrm{O} & -0.83717 & -2.80247 & 0.80083 \\ \mathrm{O} & -2.72695 & -0.84828 & -1.71833 \\ \mathrm{O} & 1.78312 & -0.45122 & -0.32497 \\ \mathrm{O} & 0.01394 & -0.84138 & 1.78842 \\ \mathrm{H} & -2.32068 & -1.33591 & 0.88384 \\ \mathrm{H} & 1.06644 & -2.57217 & 1.37541 \\ \mathrm{H} & 1.09185 & -2.28239 & -0.99016 \\ \mathrm{H} & -0.74834 & 0.29041 & -0.56678 \\ \mathrm{H} & -1.48443 & -2.52138 & -1.80527 \\ \mathrm{C} & -0.09344 & -1.19727 & 3.17686 \\ \mathrm{C} & 3.05932 & -0.97765 & -0.28645 \\ \mathrm{H} & -2.73631 & -4.09897 & -0.36345 \\ \mathrm{H} & -3.26828 & -3.58542 & 1.26126 \\ \mathrm{H} & -3.55075 & -1.36051 & -1.60603 \\ \mathrm{H} & -0.88040 & -0.29574 & -2.97304 \\ \mathrm{H} & -4.93983 & -3.33209 & -0.42784 \\ \mathrm{O} & 3.25720 & -2.16802 & -0.31182 \\ \mathrm{C} & 4.11696 & 0.12104 & -0.19306 \\ \mathrm{C} & 3.94538 & 1.10513 & -1.36833 \\ \mathrm{C} & 5.50820 & -0.52588 & -0.24888 \\ \mathrm{C} & 3.93509 & 0.85938 & 1.15120 \\ \mathrm{H} & -1.94532 & 4.99324 & 0.80348 \\ \mathrm{C} & -1.68737 & 3.96990 & 0.51585 \\ \mathrm{H} & 0.45113 & 4.34195 & 0.71031 \\ \mathrm{H} & -2.65053 & 4.16315 & -1.43012 \\ \mathrm{H} & -2.78370 & 3.10795 & 2.18871 \\ \mathrm{H} & -0.91215 & 4.46727 & -1.45267 \\ \mathrm{H} & -0.28558 & 3.60732 & 2.13573 \\ \mathrm{H} & -3.70005 & 3.16606 & 0.68140 \\ \mathrm{C} & -0.28985 & 3.60844 & 1.04129 \\ \mathrm{C} & -1.69241 & 3.83748 & -1.01501 \\ \mathrm{C} & -2.70757 & 2.98364 & 1.10459 \\ \mathrm{C} & 0.09566 & 2.19912 & 0.50276 \\ \mathrm{C} & -1.44787 & 2.34317 & -1.38587 \\ & & & \end{array}$




$\begin{array}{lrrr}\mathrm{C} & -2.24564 & 1.53204 & 0.77654 \\ \mathrm{~N} & -1.09357 & 1.60477 & -0.15226 \\ \mathrm{H} & 0.88523 & 2.24505 & -0.24841 \\ \mathrm{H} & -2.33731 & 1.86698 & -1.80241 \\ \mathrm{H} & -1.90633 & 0.99411 & 1.66277 \\ \mathrm{H} & -0.62211 & 2.22686 & -2.09130 \\ \mathrm{H} & 0.41220 & 1.51505 & 1.28915 \\ \mathrm{H} & -3.02715 & 0.95052 & 0.28513 \\ \mathrm{H} & -0.25565 & -0.26677 & 3.72507 \\ \mathrm{H} & 0.83509 & -1.66845 & 3.52399 \\ \mathrm{H} & -0.93396 & -1.87954 & 3.34672 \\ \mathrm{H} & 4.04002 & 0.59106 & -2.33031 \\ \mathrm{H} & 4.72742 & 1.86926 & -1.31400 \\ \mathrm{H} & 2.97255 & 1.60322 & -1.34014 \\ \mathrm{H} & 2.96107 & 1.35180 & 1.21100 \\ \mathrm{H} & 4.71483 & 1.62133 & 1.25050 \\ \mathrm{H} & 4.02855 & 0.16861 & 1.99597 \\ \mathrm{H} & 5.65499 & -1.06902 & -1.18641 \\ \mathrm{H} & 5.65173 & -1.23067 & 0.57426 \\ \mathrm{H} & 6.27248 & 0.25416 & -0.17643\end{array}$

\section{[2-OPiv- $\alpha$-Glc(H4)•quinuclidine] ${ }^{\bullet+}$ (transition state for HAT)}

Energy (Hartree/particle): -1325.87027726

$\begin{array}{lc}\text { Zero-point correction }= & 0.528114 \text { (Hartree/Particle) } \\ \text { Thermal correction to Energy= } & 0.557996 \\ \text { Thermal correction to Enthalpy= } & 0.558940 \\ \text { Thermal correction to Gibbs Free Energy= } & 0.465294 \\ \text { Sum of electronic and zero-point Energies }= & -1325.342163 \\ \text { Sum of electronic and thermal Energies }= & -1325.312282 \\ \text { Sum of electronic and thermal Enthalpies }= & -1325.311338 \\ \text { Sum of electronic and thermal Free Energies }= & -1325.404983\end{array}$

Number of imaginary frequencies: $1,-1067.6370$

\section{Geometry:}

$\begin{array}{llcc}\mathrm{C} & -1.21390 & 1.86868 & -0.92327 \\ \mathrm{C} & -1.17480 & 0.55997 & -0.13662 \\ \mathrm{C} & -0.41770 & 0.71372 & 1.18506 \\ \mathrm{O} & -0.27263 & -0.53831 & 1.84739 \\ \mathrm{C} & 0.96514 & 1.29828 & 0.91501 \\ \mathrm{C} & 0.91855 & 2.50849 & -0.03995 \\ \mathrm{C} & 2.28686 & 2.97695 & -0.54527\end{array}$




\begin{tabular}{|c|c|c|c|}
\hline $\mathrm{O}$ & 3.23722 & 3.05867 & 0.53826 \\
\hline $\mathrm{O}$ & 0.15492 & 2.23863 & -1.20623 \\
\hline $\mathrm{O}$ & 1.66434 & 1.52027 & 2.07594 \\
\hline $\mathrm{O}$ & -2.49668 & 0.09487 & 0.15192 \\
\hline $\mathrm{O}$ & -1.89656 & 2.83110 & -0.19344 \\
\hline $\mathrm{H}$ & 0.45086 & 3.32085 & 0.54226 \\
\hline $\mathrm{H}$ & -1.65574 & 1.71979 & -1.91795 \\
\hline $\mathrm{H}$ & -0.67826 & -0.18363 & -0.76117 \\
\hline $\mathrm{H}$ & -0.95192 & 1.42885 & 1.82914 \\
\hline $\mathrm{H}$ & 1.59732 & 0.32880 & 0.31803 \\
\hline $\mathrm{C}$ & -2.27809 & 3.98928 & -0.95430 \\
\hline $\mathrm{C}$ & -2.84621 & -1.14619 & -0.34770 \\
\hline $\mathrm{H}$ & 2.66969 & 2.25959 & -1.27631 \\
\hline $\mathrm{H}$ & 2.17325 & 3.94169 & -1.04826 \\
\hline $\mathrm{H}$ & 2.40089 & 2.13484 & 1.84407 \\
\hline $\mathrm{H}$ & -1.13519 & -0.78026 & 2.21127 \\
\hline $\mathrm{H}$ & 3.46549 & 3.98250 & 0.70014 \\
\hline $\mathrm{O}$ & -2.09602 & -1.81103 & -1.02271 \\
\hline $\mathrm{C}$ & -4.25872 & -1.52714 & 0.08993 \\
\hline $\mathrm{C}$ & -5.25120 & -0.44233 & -0.37983 \\
\hline $\mathrm{C}$ & -4.27843 & -1.62644 & 1.63207 \\
\hline $\mathrm{C}$ & -4.62484 & -2.88303 & -0.52790 \\
\hline $\mathrm{H}$ & 4.36001 & -3.73978 & -0.79335 \\
\hline $\mathrm{C}$ & 3.75632 & -2.85608 & -0.56748 \\
\hline $\mathrm{H}$ & 3.03614 & -3.54519 & 1.36228 \\
\hline $\mathrm{H}$ & 2.44532 & -3.03053 & -2.29211 \\
\hline $\mathrm{H}$ & 5.39833 & -1.43341 & -0.62804 \\
\hline $\mathrm{H}$ & 1.87915 & -3.91689 & -0.87583 \\
\hline $\mathrm{H}$ & 4.57299 & -2.68137 & 1.44471 \\
\hline $\mathrm{H}$ & 4.63674 & -1.70720 & -2.19652 \\
\hline $\mathrm{C}$ & 3.59664 & -2.69974 & 0.95198 \\
\hline $\mathrm{C}$ & 2.36408 & -2.99244 & -1.20158 \\
\hline $\mathrm{C}$ & 4.43826 & -1.59808 & -1.12642 \\
\hline $\mathrm{C}$ & 2.83943 & -1.37084 & 1.24073 \\
\hline $\mathrm{C}$ & 1.49538 & -1.77368 & -0.77199 \\
\hline $\mathrm{C}$ & 3.49922 & -0.37718 & -0.89340 \\
\hline $\mathrm{N}$ & 2.35953 & -0.80628 & -0.04780 \\
\hline $\mathrm{H}$ & 1.96897 & -1.51033 & 1.88074 \\
\hline $\mathrm{H}$ & 1.06628 & -1.25923 & -1.63427 \\
\hline $\mathrm{H}$ & 4.01160 & 0.43950 & -0.37982 \\
\hline $\mathrm{H}$ & 0.68491 & -2.05324 & -0.09946 \\
\hline $\mathrm{H}$ & 3.48656 & -0.62036 & 1.69951 \\
\hline $\mathrm{H}$ & 3.08432 & -0.00025 & -1.83125 \\
\hline $\mathrm{H}$ & -2.83313 & 4.63505 & -0.27230 \\
\hline $\mathrm{H}$ & -2.92281 & 3.69884 & -1.79423 \\
\hline $\mathrm{H}$ & -1.39781 & 4.52022 & -1.33590 \\
\hline
\end{tabular}




$\begin{array}{lrrr}\mathrm{H} & -4.60244 & -2.83940 & -1.62034 \\ \mathrm{H} & -5.63518 & -3.16254 & -0.21361 \\ \mathrm{H} & -3.93296 & -3.66701 & -0.20760 \\ \mathrm{H} & -5.23319 & -0.34043 & -1.47033 \\ \mathrm{H} & -5.02583 & 0.52916 & 0.06674 \\ \mathrm{H} & -6.26485 & -0.73306 & -0.08603 \\ \mathrm{H} & -4.06002 & -0.66147 & 2.09824 \\ \mathrm{H} & -3.55630 & -2.37093 & 1.98822 \\ \mathrm{H} & -5.27247 & -1.94594 & 1.96044\end{array}$

\section{[2-OPiv- $\alpha$-Glc(H5)•quinuclidine $]^{\bullet+}$ (transition state for HAT)}

Energy (Hartree/particle): -1325.86348671

$\begin{array}{lc}\text { Zero-point correction }= & 0.527881 \text { (Hartree/Particle) } \\ \text { Thermal correction to Energy= } & 0.557801 \\ \text { Thermal correction to Enthalpy= } & 0.558745 \\ \text { Thermal correction to Gibbs Free Energy= } & 0.465368 \\ \text { Sum of electronic and zero-point Energies }= & -1325.335605 \\ \text { Sum of electronic and thermal Energies }= & -1325.305686 \\ \text { Sum of electronic and thermal Enthalpies }= & -1325.304742 \\ \text { Sum of electronic and thermal Free Energies }= & -1325.398119\end{array}$

Number of imaginary frequencies: 1, -1058.8104

\begin{tabular}{lrcc}
\multicolumn{4}{l}{ Geometry: } \\
$\mathrm{C}$ & -0.90086 & 0.19008 & 1.25647 \\
$\mathrm{C}$ & -1.63202 & 0.92820 & 0.12655 \\
$\mathrm{C}$ & -0.69242 & 1.27781 & -1.01440 \\
$\mathrm{O}$ & -1.41850 & 2.02782 & -1.97151 \\
$\mathrm{C}$ & 0.47119 & 2.10485 & -0.47121 \\
$\mathrm{C}$ & 1.10171 & 1.51862 & 0.80923 \\
$\mathrm{C}$ & 2.00852 & 2.47489 & 1.57704 \\
$\mathrm{O}$ & 2.96394 & 3.03990 & 0.67391 \\
$\mathrm{O}$ & 0.23860 & 0.97049 & 1.73127 \\
$\mathrm{O}$ & 1.41892 & 2.23872 & -1.52089 \\
$\mathrm{O}$ & -2.67582 & 0.10646 & -0.39717 \\
$\mathrm{O}$ & -0.48207 & -1.06852 & 0.83540 \\
$\mathrm{H}$ & 1.89234 & 0.59584 & 0.34670 \\
$\mathrm{H}$ & -1.54325 & 0.12835 & 2.13754 \\
$\mathrm{H}$ & -2.06377 & 1.84305 & 0.54870 \\
$\mathrm{H}$ & -0.30096 & 0.35085 & -1.45857 \\
$\mathrm{H}$ & 0.06729 & 3.09595 & -0.19332 \\
$\mathrm{C}$ & -0.62337 & -2.10479 & 1.82406
\end{tabular}




\begin{tabular}{|c|c|c|c|}
\hline $\mathrm{C}$ & -3.83258 & 0.03868 & 0.34710 \\
\hline $\mathrm{H}$ & 1.37065 & 3.25539 & 2.01951 \\
\hline $\mathrm{H}$ & 2.50176 & 1.93640 & 2.39910 \\
\hline $\mathrm{H}$ & 2.08880 & 2.87191 & -1.21464 \\
\hline $\mathrm{H}$ & -0.79781 & 2.29250 & -2.66621 \\
\hline $\mathrm{H}$ & 3.37008 & 3.80821 & 1.09608 \\
\hline $\mathrm{O}$ & -3.93114 & 0.57607 & 1.42601 \\
\hline $\mathrm{C}$ & -4.89915 & -0.78758 & -0.36722 \\
\hline $\mathrm{C}$ & -6.16080 & -0.83196 & 0.50467 \\
\hline $\mathrm{C}$ & -4.35663 & -2.21688 & -0.58684 \\
\hline $\mathrm{C}$ & -5.21507 & -0.12885 & -1.72774 \\
\hline $\mathrm{H}$ & 5.10559 & -3.03771 & -0.97249 \\
\hline $\mathrm{C}$ & 4.41049 & -2.23995 & -0.69612 \\
\hline $\mathrm{H}$ & 3.76020 & -3.28959 & 1.10005 \\
\hline $\mathrm{H}$ & 3.27272 & -2.45496 & -2.54205 \\
\hline $\mathrm{H}$ & 6.00116 & -0.75807 & -0.56328 \\
\hline $\mathrm{H}$ & 2.58839 & -3.32551 & -1.16872 \\
\hline $\mathrm{H}$ & 5.02809 & -2.09557 & 1.38260 \\
\hline $\mathrm{H}$ & 5.15505 & -0.77032 & -2.11146 \\
\hline $\mathrm{C}$ & 4.11698 & -2.29674 & 0.81103 \\
\hline $\mathrm{C}$ & 3.08966 & -2.39879 & -1.46520 \\
\hline $\mathrm{C}$ & 5.01835 & -0.86941 & -1.03035 \\
\hline $\mathrm{C}$ & 3.02862 & -1.23519 & 1.14238 \\
\hline $\mathrm{C}$ & 2.18075 & -1.17370 & -1.15626 \\
\hline $\mathrm{C}$ & 4.06372 & 0.24424 & -0.50951 \\
\hline $\mathrm{N}$ & 2.79962 & -0.39089 & -0.05549 \\
\hline $\mathrm{H}$ & 2.07280 & -1.69016 & 1.40013 \\
\hline $\mathrm{H}$ & 2.08962 & -0.49843 & -2.00863 \\
\hline $\mathrm{H}$ & 4.48103 & 0.78706 & 0.33990 \\
\hline $\mathrm{H}$ & 1.18267 & -1.46824 & -0.83051 \\
\hline $\mathrm{H}$ & 3.33167 & -0.57886 & 1.96189 \\
\hline $\mathrm{H}$ & 3.80675 & 0.96636 & -1.28387 \\
\hline $\mathrm{H}$ & -0.26789 & -3.02617 & 1.35806 \\
\hline $\mathrm{H}$ & -1.67628 & -2.22433 & 2.10288 \\
\hline $\mathrm{H}$ & -0.02726 & -1.88471 & 2.71876 \\
\hline $\mathrm{H}$ & -5.12798 & -2.82198 & -1.07399 \\
\hline $\mathrm{H}$ & -4.10886 & -2.69531 & 0.36784 \\
\hline $\mathrm{H}$ & -3.46644 & -2.21469 & -1.22118 \\
\hline $\mathrm{H}$ & -5.99995 & -0.70411 & -2.22958 \\
\hline $\mathrm{H}$ & -4.33474 & -0.10028 & -2.37438 \\
\hline $\mathrm{H}$ & -5.57941 & 0.89489 & -1.59234 \\
\hline $\mathrm{H}$ & -6.92974 & -1.42294 & -0.00274 \\
\hline $\mathrm{H}$ & -6.55587 & 0.17212 & 0.68108 \\
\hline $\mathrm{H}$ & -5.95780 & -1.28916 & 1.47737 \\
\hline
\end{tabular}




\section{[2-OPiv- $\alpha$-Glc] (PCM(acetonitrile)}

Energy (Hartree/particle): -996.907000108

$\begin{array}{lc}\text { Zero-point correction }= & 0.339041 \text { (Hartree/Particle) } \\ \text { Thermal correction to Energy }= & 0.360730 \\ \text { Thermal correction to Enthalpy= } & 0.361674 \\ \text { Thermal correction to Gibbs Free Energy }= & 0.287985 \\ \text { Sum of electronic and zero-point Energies }= & -996.567959 \\ \text { Sum of electronic and thermal Energies }= & -996.546270 \\ \text { Sum of electronic and thermal Enthalpies }= & -996.545326 \\ \text { Sum of electronic and thermal Free Energies }= & -996.619015\end{array}$

Number of imaginary frequencies: 0

$\begin{array}{lrrr}\text { Geometry: } & & \\ \mathrm{C} & -0.49481 & 1.13692 & 0.39823 \\ \mathrm{C} & 0.03829 & -0.30609 & 0.41226 \\ \mathrm{C} & -0.85560 & -1.23307 & -0.39313 \\ \mathrm{O} & -0.38242 & -2.57278 & -0.22834 \\ \mathrm{C} & -2.29857 & -1.09803 & 0.09239 \\ \mathrm{C} & -2.74626 & 0.36977 & 0.09579 \\ \mathrm{C} & -4.11688 & 0.57025 & 0.74615 \\ \mathrm{O} & -5.15157 & -0.16260 & 0.06605 \\ \mathrm{O} & -1.83429 & 1.15797 & 0.88215 \\ \mathrm{O} & -3.10215 & -1.90496 & -0.77255 \\ \mathrm{O} & 1.36542 & -0.36373 & -0.15311 \\ \mathrm{O} & -0.37252 & 1.64497 & -0.90287 \\ \mathrm{H} & -2.76981 & 0.73955 & -0.93985 \\ \mathrm{H} & 0.06223 & 1.75770 & 1.11190 \\ \mathrm{H} & 0.08039 & -0.63762 & 1.45331 \\ \mathrm{H} & -0.81757 & -0.94574 & -1.45423 \\ \mathrm{H} & -2.34953 & -1.47783 & 1.12719 \\ \mathrm{C} & -0.59454 & 3.05852 & -0.98666 \\ \mathrm{C} & 2.41167 & -0.08226 & 0.66337 \\ \mathrm{H} & -4.09474 & 0.18369 & 1.77012 \\ \mathrm{H} & -4.35175 & 1.64115 & 0.78259 \\ \mathrm{H} & -4.02786 & -1.67558 & -0.56898 \\ \mathrm{H} & -1.03269 & -3.14531 & -0.66178 \\ \mathrm{H} & -5.35443 & 0.30218 & -0.75865 \\ \mathrm{O} & 2.28271 & 0.19796 & 1.83874 \\ \mathrm{C} & 3.73833 & -0.15109 & -0.10022 \\ \mathrm{C} & 4.89651 & 0.09892 & 0.87393 \\ \mathrm{C} & 3.72622 & 0.94085 & -1.19254 \\ \mathrm{C} & 3.88868 & -1.54230 & -0.75010 \\ \mathrm{H} & -0.40174 & 3.34188 & -2.02332\end{array}$




$\begin{array}{rrrr}\mathrm{H} & 0.09593 & 3.59740 & -0.32276 \\ \mathrm{H} & -1.62692 & 3.31520 & -0.72083 \\ \mathrm{H} & 4.85145 & -1.59352 & -1.26996 \\ \mathrm{H} & 3.09236 & -1.73231 & -1.47383 \\ \mathrm{H} & 3.86704 & -2.33356 & 0.00726 \\ \mathrm{H} & 5.84393 & 0.05691 & 0.32658 \\ \mathrm{H} & 4.92029 & -0.65828 & 1.66360 \\ \mathrm{H} & 4.81283 & 1.08227 & 1.34583 \\ \mathrm{H} & 4.68474 & 0.92938 & -1.72243 \\ \mathrm{H} & 3.59032 & 1.93500 & -0.75259 \\ \mathrm{H} & 2.92592 & 0.76846 & -1.91660\end{array}$

\section{[2-OPiv- $\alpha$-Glc(H2)•quinuclidine $]^{\bullet+}$ (transition state for HAT) (PCM(acetonitrile)}

Energy (Hartree/particle): -1325.92462258

Zero-point correction $=$

Thermal correction to Energy=
0.527226 (Hartree/Particle)

0.557133

0.558077

Thermal correction to Gibbs Free Energy $=0.466412$

Sum of electronic and zero-point Energies $=\quad-1325.397397$

Sum of electronic and thermal Energies $=\quad-1325.367490$

Sum of electronic and thermal Enthalpies $=\quad-1325.366546$

Sum of electronic and thermal Free Energies $=\quad-1325.458211$

Number of imaginary frequencies: $\mathbf{1 ,}-1449.5690$

\section{Geometry:}

$\begin{array}{lrrr}\mathrm{C} & -0.49481 & 1.13692 & 0.39823 \\ \mathrm{C} & 0.03829 & -0.30609 & 0.41226 \\ \mathrm{C} & -0.85560 & -1.23307 & -0.39313 \\ \mathrm{O} & -0.38242 & -2.57278 & -0.22834 \\ \mathrm{C} & -2.29857 & -1.09803 & 0.09239 \\ \mathrm{C} & -2.74626 & 0.36977 & 0.09579 \\ \mathrm{C} & -4.11688 & 0.57025 & 0.74615 \\ \mathrm{O} & -5.15157 & -0.16260 & 0.06605 \\ \mathrm{O} & -1.83429 & 1.15797 & 0.88215 \\ \mathrm{O} & -3.10215 & -1.90496 & -0.77255 \\ \mathrm{O} & 1.36542 & -0.36373 & -0.15311 \\ \mathrm{O} & -0.37252 & 1.64497 & -0.90287 \\ \mathrm{H} & -2.76981 & 0.73955 & -0.93985 \\ \mathrm{H} & 0.06223 & 1.75770 & 1.11190 \\ \mathrm{H} & 0.08039 & -0.63762 & 1.45331 \\ \mathrm{H} & -0.81757 & -0.94574 & -1.45423 \\ \mathrm{H} & -2.34953 & -1.47783 & 1.12719\end{array}$




$\begin{array}{lrrr}\mathrm{C} & -0.59454 & 3.05852 & -0.98666 \\ \mathrm{C} & 2.41167 & -0.08226 & 0.66337 \\ \mathrm{H} & -4.09474 & 0.18369 & 1.77012 \\ \mathrm{H} & -4.35175 & 1.64115 & 0.78259 \\ \mathrm{H} & -4.02786 & -1.67558 & -0.56898 \\ \mathrm{H} & -1.03269 & -3.14531 & -0.66178 \\ \mathrm{H} & -5.35443 & 0.30218 & -0.75865 \\ \mathrm{O} & 2.28271 & 0.19796 & 1.83874 \\ \mathrm{C} & 3.73833 & -0.15109 & -0.10022 \\ \mathrm{C} & 4.89651 & 0.09892 & 0.87393 \\ \mathrm{C} & 3.72622 & 0.94085 & -1.19254 \\ \mathrm{C} & 3.88868 & -1.54230 & -0.75010 \\ \mathrm{H} & -0.40174 & 3.34188 & -2.02332 \\ \mathrm{H} & 0.09593 & 3.59740 & -0.32276 \\ \mathrm{H} & -1.62692 & 3.31520 & -0.72083 \\ \mathrm{H} & 4.85145 & -1.59352 & -1.26996 \\ \mathrm{H} & 3.09236 & -1.73231 & -1.47383 \\ \mathrm{H} & 3.86704 & -2.33356 & 0.00726 \\ \mathrm{H} & 5.84393 & 0.05691 & 0.32658 \\ \mathrm{H} & 4.92029 & -0.65828 & 1.66360 \\ \mathrm{H} & 4.81283 & 1.08227 & 1.34583 \\ \mathrm{H} & 4.68474 & 0.92938 & -1.72243 \\ \mathrm{H} & 3.59032 & 1.93500 & -0.75259 \\ \mathrm{H} & 2.92592 & 0.76846 & -1.91660\end{array}$

\section{[2-OPiv- $\alpha$-Glc(H3)•quinuclidine $]^{\bullet+}$ (transition state for HAT) (PCM(acetonitrile)}

Energy (Hartree/particle): -1325.93811216

$\begin{array}{lc}\text { Zero-point correction }= & 0.528083 \text { (Hartree/Particle) } \\ \text { Thermal correction to Energy= } & 0.557670 \\ \text { Thermal correction to Enthalpy= } & 0.558614 \\ \text { Thermal correction to Gibbs Free Energy= } & 0.467202 \\ \text { Sum of electronic and zero-point Energies }= & -1325.410029 \\ \text { Sum of electronic and thermal Energies }= & -1325.380442 \\ \text { Sum of electronic and thermal Enthalpies }= & -1325.379498 \\ \text { Sum of electronic and thermal Free Energies }= & -1325.470910\end{array}$

Number of imaginary frequencies: $1,-1168.8932$

Geometry:
$\begin{array}{lrrr}\mathrm{C} & -0.71174 & -1.15007 & -1.09666 \\ \mathrm{C} & -0.15996 & -0.61172 & 0.23499 \\ \mathrm{C} & -1.12361 & -0.69737 & 1.40309 \\ \mathrm{O} & -0.61972 & 0.10309 & 2.46995\end{array}$




\begin{tabular}{|c|c|c|c|}
\hline $\mathrm{C}$ & -2.54821 & -0.30322 & 1.01872 \\
\hline $\mathrm{C}$ & -2.96676 & -0.98708 & -0.28755 \\
\hline $\mathrm{C}$ & -4.31406 & -0.49805 & -0.80760 \\
\hline $\mathrm{O}$ & -5.31414 & -0.84286 & 0.16786 \\
\hline $\mathrm{O}$ & -2.01931 & -0.65029 & -1.31691 \\
\hline $\mathrm{O}$ & -3.37084 & -0.67354 & 2.12249 \\
\hline $\mathrm{O}$ & 1.06848 & -1.12541 & 0.65364 \\
\hline $\mathrm{O}$ & -0.63872 & -2.54830 & -1.02417 \\
\hline $\mathrm{H}$ & -2.99739 & -2.07464 & -0.13865 \\
\hline $\mathrm{H}$ & -0.13517 & -0.77582 & -1.94694 \\
\hline $\mathrm{H}$ & 0.03864 & 0.67953 & 0.02327 \\
\hline $\mathrm{H}$ & -1.14824 & -1.75925 & 1.70667 \\
\hline $\mathrm{H}$ & -2.58986 & 0.78548 & 0.86277 \\
\hline $\mathrm{C}$ & -0.79056 & -3.19473 & -2.30032 \\
\hline $\mathrm{C}$ & 2.14126 & -1.25571 & -0.21269 \\
\hline $\mathrm{H}$ & -4.27134 & 0.58928 & -0.95581 \\
\hline $\mathrm{H}$ & -4.52761 & -0.97839 & -1.77148 \\
\hline $\mathrm{H}$ & -4.28970 & -0.64390 & 1.79214 \\
\hline $\mathrm{H}$ & -1.26521 & 0.04619 & 3.19025 \\
\hline $\mathrm{H}$ & -6.10844 & -0.32490 & -0.01898 \\
\hline $\mathrm{O}$ & 2.16086 & -0.72439 & -1.29688 \\
\hline $\mathrm{C}$ & 3.23896 & -2.09942 & 0.42040 \\
\hline $\mathrm{C}$ & 4.41112 & -2.20861 & -0.56316 \\
\hline $\mathrm{C}$ & 2.67044 & -3.50182 & 0.73100 \\
\hline $\mathrm{C}$ & 3.70470 & -1.41532 & 1.72584 \\
\hline $\mathrm{H}$ & 1.39999 & 5.42164 & -0.52841 \\
\hline $\mathrm{C}$ & 1.09048 & 4.37948 & -0.40919 \\
\hline $\mathrm{H}$ & -0.44305 & 4.89130 & 1.04965 \\
\hline $\mathrm{H}$ & 3.06386 & 3.77100 & 0.28709 \\
\hline $\mathrm{H}$ & 0.57066 & 4.19256 & -2.51613 \\
\hline $\mathrm{H}$ & 1.90413 & 4.09468 & 1.58391 \\
\hline $\mathrm{H}$ & -1.04378 & 4.72957 & -0.60680 \\
\hline $\mathrm{H}$ & 2.18505 & 3.59173 & -2.11223 \\
\hline $\mathrm{C}$ & -0.34615 & 4.31441 & 0.12599 \\
\hline $\mathrm{C}$ & 2.01719 & 3.66502 & 0.58446 \\
\hline $\mathrm{C}$ & 1.15087 & 3.65457 & -1.76172 \\
\hline $\mathrm{C}$ & -0.70531 & 2.82706 & 0.41504 \\
\hline $\mathrm{C}$ & 1.64769 & 2.15417 & 0.61086 \\
\hline $\mathrm{C}$ & 0.56285 & 2.22233 & -1.59219 \\
\hline $\mathrm{N}$ & 0.37630 & 1.97133 & -0.13895 \\
\hline $\mathrm{H}$ & -0.77353 & 2.60974 & 1.48095 \\
\hline $\mathrm{H}$ & 2.40306 & 1.54725 & 0.11279 \\
\hline $\mathrm{H}$ & -0.41552 & 2.12023 & -2.06433 \\
\hline $\mathrm{H}$ & 1.49299 & 1.77873 & 1.62271 \\
\hline $\mathrm{H}$ & -1.63843 & 2.53987 & -0.07038 \\
\hline $\mathrm{H}$ & 1.23084 & 1.45355 & -1.97875 \\
\hline
\end{tabular}




$\begin{array}{lrrr}\mathrm{H} & -0.65009 & -4.26181 & -2.12002 \\ \mathrm{H} & -0.02932 & -2.83360 & -3.00401 \\ \mathrm{H} & -1.78965 & -3.01582 & -2.71312 \\ \mathrm{H} & 4.09128 & -0.41018 & 1.52693 \\ \mathrm{H} & 4.51155 & -2.01072 & 2.16480 \\ \mathrm{H} & 2.89163 & -1.34199 & 2.45189 \\ \mathrm{H} & 4.10103 & -2.68543 & -1.49761 \\ \mathrm{H} & 5.20193 & -2.81474 & -0.11084 \\ \mathrm{H} & 4.82277 & -1.22304 & -0.79963 \\ \mathrm{H} & 2.30177 & -3.98644 & -0.17886 \\ \mathrm{H} & 1.85325 & -3.44999 & 1.45469 \\ \mathrm{H} & 3.46962 & -4.12066 & 1.15144\end{array}$

\section{$[\text { 2-OPiv- } \alpha \text {-Glc(H4)•quinuclidine }]^{++}($transition state for HAT) (PCM(acetonitrile)}

Energy (Hartree/particle): -1325.93610966

$\begin{array}{lc}\text { Zero-point correction }= & 0.528083 \text { (Hartree/Particle) } \\ \text { Zero-point correction }= & 0.528444 \text { (Hartree/Particle) } \\ \text { Thermal correction to Energy= } & 0.557937 \\ \text { Thermal correction to Enthalpy= } & 0.558881 \\ \text { Thermal correction to Gibbs Free Energy= } & 0.466893 \\ \text { Sum of electronic and zero-point Energies }= & -1325.407665 \\ \text { Sum of electronic and thermal Energies }= & -1325.378173 \\ \text { Sum of electronic and thermal Enthalpies }= & -1325.377229 \\ \text { Sum of electronic and thermal Free Energies }= & -1325.469217\end{array}$

Number of imaginary frequencies: $1,-1174.6756$

\section{Geometry:}

$\begin{array}{llll}\mathrm{C} & 0.30883 & -1.93159 & 0.95587 \\ \mathrm{C} & 0.75016 & -1.42521 & -0.42879 \\ \mathrm{C} & -0.40298 & -0.80040 & -1.18155 \\ \mathrm{O} & -0.02585 & -0.38815 & -2.44707 \\ \mathrm{C} & -1.65513 & -1.66518 & -1.16146 \\ \mathrm{C} & -1.96636 & -2.17858 & 0.25290 \\ \mathrm{C} & -3.05358 & -3.24744 & 0.24681 \\ \mathrm{O} & -4.25237 & -2.64417 & -0.27374 \\ \mathrm{O} & -0.80344 & -2.80860 & 0.81029 \\ \mathrm{O} & -2.70900 & -0.89214 & -1.72549 \\ \mathrm{O} & 1.81395 & -0.46470 & -0.32505 \\ \mathrm{O} & 0.03531 & -0.82469 & 1.76609 \\ \mathrm{H} & -2.28448 & -1.34104 & 0.88447 \\ \mathrm{H} & 1.09587 & -2.55609 & 1.39591 \\ \mathrm{H} & 1.11032 & -2.29396 & -0.99216\end{array}$




\begin{tabular}{|c|c|c|c|}
\hline $\mathrm{H}$ & -0.74078 & 0.29494 & -0.57215 \\
\hline $\mathrm{H}$ & -1.44152 & -2.54468 & -1.79681 \\
\hline $\mathrm{C}$ & -0.11365 & -1.14528 & 3.15887 \\
\hline $\mathrm{C}$ & 3.08765 & -0.95827 & -0.30546 \\
\hline $\mathrm{H}$ & -2.73403 & -4.08868 & -0.38210 \\
\hline $\mathrm{H}$ & -3.21171 & -3.60959 & 1.27077 \\
\hline $\mathrm{H}$ & -3.52917 & -1.39628 & -1.55405 \\
\hline $\mathrm{H}$ & -0.83203 & -0.28878 & -2.98393 \\
\hline $\mathrm{H}$ & -4.86376 & -3.35089 & -0.52065 \\
\hline $\mathrm{O}$ & 3.33015 & -2.14401 & -0.37826 \\
\hline $\mathrm{C}$ & 4.11496 & 0.16629 & -0.16656 \\
\hline $\mathrm{C}$ & 3.93073 & 1.17746 & -1.31713 \\
\hline $\mathrm{C}$ & 5.52637 & -0.43351 & -0.22063 \\
\hline $\mathrm{C}$ & 3.89383 & 0.86328 & 1.19391 \\
\hline $\mathrm{H}$ & -2.03916 & 4.95030 & 0.78807 \\
\hline $\mathrm{C}$ & -1.75813 & 3.93280 & 0.50124 \\
\hline $\mathrm{H}$ & 0.36972 & 4.34866 & 0.71270 \\
\hline $\mathrm{H}$ & -2.70942 & 4.10899 & -1.45105 \\
\hline $\mathrm{H}$ & -2.84669 & 3.04517 & 2.16435 \\
\hline $\mathrm{H}$ & -0.97196 & 4.44168 & -1.45828 \\
\hline $\mathrm{H}$ & -0.36458 & 3.58838 & 2.13107 \\
\hline $\mathrm{H}$ & -3.75203 & 3.08351 & 0.64494 \\
\hline $\mathrm{C}$ & -0.35842 & 3.59993 & 1.03710 \\
\hline $\mathrm{C}$ & -1.74838 & 3.80203 & -1.02901 \\
\hline $\mathrm{C}$ & -2.76122 & 2.92541 & 1.08076 \\
\hline $\mathrm{C}$ & 0.06374 & 2.20405 & 0.49398 \\
\hline $\mathrm{C}$ & -1.47823 & 2.31333 & -1.40095 \\
\hline $\mathrm{C}$ & -2.26536 & 1.48425 & 0.75981 \\
\hline $\mathrm{N}$ & -1.11020 & 1.58261 & -0.16527 \\
\hline $\mathrm{H}$ & 0.85054 & 2.27958 & -0.25691 \\
\hline $\mathrm{H}$ & -2.36052 & 1.82333 & -1.81419 \\
\hline $\mathrm{H}$ & -1.92080 & 0.96051 & 1.65123 \\
\hline $\mathrm{H}$ & -0.65193 & 2.21479 & -2.10713 \\
\hline $\mathrm{H}$ & 0.39268 & 1.52961 & 1.28268 \\
\hline $\mathrm{H}$ & -3.03222 & 0.88826 & 0.26467 \\
\hline $\mathrm{H}$ & -0.24290 & -0.19531 & 3.68044 \\
\hline $\mathrm{H}$ & 0.78597 & -1.65225 & 3.53084 \\
\hline $\mathrm{H}$ & -0.98976 & -1.78185 & 3.32472 \\
\hline $\mathrm{H}$ & 4.05552 & 0.69124 & -2.29054 \\
\hline $\mathrm{H}$ & 4.68851 & 1.96269 & -1.22690 \\
\hline $\mathrm{H}$ & 2.94388 & 1.64478 & -1.28790 \\
\hline $\mathrm{H}$ & 2.90907 & 1.33203 & 1.24755 \\
\hline $\mathrm{H}$ & 4.65514 & 1.63928 & 1.32487 \\
\hline $\mathrm{H}$ & 3.98563 & 0.15017 & 2.02024 \\
\hline $\mathrm{H}$ & 5.70317 & -0.94514 & -1.17144 \\
\hline $\mathrm{H}$ & 5.68381 & -1.15107 & 0.58972 \\
\hline
\end{tabular}


$\begin{array}{llll}\text { H } & 6.26199 & 0.37072 & -0.11872\end{array}$

[2-OPiv- $\alpha$-Glc(H5)•quinuclidine $]^{\bullet+}$ (transition state for HAT) (PCM(acetonitrile)

Energy (Hartree/particle): -1325.93216460

Zero-point correction=

Thermal correction to Energy=

Thermal correction to Enthalpy=

Thermal correction to Gibbs Free Energy=

Sum of electronic and zero-point Energies=

Sum of electronic and thermal Energies $=$

Sum of electronic and thermal Enthalpies=

Sum of electronic and thermal Free Energies=
0.527796 (Hartree/Particle)

0.557601

0.558545

0.466376

$-1325.404369$

$-1325.374563$

$-1325.373619$

$-1325.465788$

Number of imaginary frequencies: 1, -1212.0009

\section{Geometry:}

$\begin{array}{lrrr}\mathrm{C} & -1.24303 & 1.53439 & -0.90879 \\ \mathrm{C} & -1.12101 & 0.29800 & -0.00951 \\ \mathrm{C} & -0.33115 & 0.57844 & 1.27088 \\ \mathrm{O} & -0.06917 & -0.61643 & 1.99931 \\ \mathrm{C} & 0.99164 & 1.25186 & 0.92394 \\ \mathrm{C} & 0.80628 & 2.41526 & -0.06175 \\ \mathrm{C} & 2.11055 & 3.04332 & -0.55862 \\ \mathrm{O} & 2.94936 & 3.43685 & 0.54631 \\ \mathrm{O} & 0.08053 & 1.99856 & -1.21543 \\ \mathrm{O} & 1.71745 & 1.56966 & 2.04665 \\ \mathrm{O} & -2.41181 & -0.18403 & 0.40877 \\ \mathrm{O} & -2.02381 & 2.49100 & -0.26127 \\ \mathrm{H} & 0.23499 & 3.18623 & 0.48153 \\ \mathrm{H} & -1.66529 & 1.26648 & -1.88530 \\ \mathrm{H} & -0.62825 & -0.48072 & -0.59260 \\ \mathrm{H} & -0.89996 & 1.28710 & 1.89348 \\ \mathrm{H} & 1.67860 & 0.30765 & 0.32481 \\ \mathrm{C} & -2.41963 & 3.58370 & -1.10637 \\ \mathrm{C} & -3.05714 & -1.05173 & -0.42597 \\ \mathrm{H} & 2.68368 & 2.32220 & -1.14309 \\ \mathrm{H} & 1.87548 & 3.89826 & -1.20005 \\ \mathrm{H} & 2.36250 & 2.27096 & 1.77312 \\ \mathrm{H} & -0.92276 & -0.98479 & 2.26982 \\ \mathrm{H} & 2.67695 & 4.31890 & 0.83839 \\ \mathrm{O} & -2.58430 & -1.42108 & -1.47959 \\ \mathrm{C} & -4.42225 & -1.44552 & 0.13987 \\ \mathrm{C} & -5.31564 & -0.18430 & 0.14745\end{array}$




$\begin{array}{lrrr}\mathrm{C} & -4.25881 & -1.98337 & 1.57626 \\ \mathrm{C} & -5.04669 & -2.52311 & -0.75620 \\ \mathrm{H} & 4.75505 & -3.50534 & -0.82849 \\ \mathrm{C} & 4.07878 & -2.67816 & -0.59483 \\ \mathrm{H} & 4.25645 & -3.00482 & 1.55112 \\ \mathrm{H} & 2.43017 & -3.58058 & -1.69430 \\ \mathrm{H} & 5.36079 & -1.21815 & -1.58011 \\ \mathrm{H} & 2.40030 & -3.89768 & 0.04544 \\ \mathrm{H} & 5.33244 & -1.75239 & 0.91770 \\ \mathrm{H} & 4.03654 & -1.81772 & -2.58798 \\ \mathrm{C} & 4.32898 & -2.18035 & 0.83630 \\ \mathrm{C} & 2.61925 & -3.13916 & -0.71184 \\ \mathrm{C} & 4.30893 & -1.51683 & -1.57210 \\ \mathrm{C} & 3.25940 & -1.10533 & 1.18389 \\ \mathrm{C} & 1.68855 & -1.90796 & -0.51346 \\ \mathrm{C} & 3.43510 & -0.30914 & -1.12420 \\ \mathrm{~N} & 2.51286 & -0.76043 & -0.05233 \\ \mathrm{H} & 2.52712 & -1.46401 & 1.90759 \\ \mathrm{H} & 1.21101 & -1.60782 & -1.44796 \\ \mathrm{H} & 4.04444 & 0.49611 & -0.71068 \\ \mathrm{H} & 0.92401 & -2.08850 & 0.24154 \\ \mathrm{H} & 3.71024 & -0.18957 & 1.56935 \\ \mathrm{H} & 2.83127 & 0.08093 & -1.94521 \\ \mathrm{H} & -3.07744 & 4.21410 & -0.50569 \\ \mathrm{H} & -2.96324 & 3.21043 & -1.98442 \\ \mathrm{H} & -1.54960 & 4.16393 & -1.43436 \\ \mathrm{H} & -5.17786 & -2.16093 & -1.77979 \\ \mathrm{H} & -6.02853 & -2.79797 & -0.35757 \\ \mathrm{H} & -4.42301 & -3.42182 & -0.78774 \\ \mathrm{H} & -5.42533 & 0.22498 & -0.86268 \\ \mathrm{H} & -4.90081 & 0.59188 & 0.79573 \\ \mathrm{H} & -6.31045 & -0.45343 & 0.51778 \\ \mathrm{H} & -3.87134 & -1.21498 & 2.24984 \\ \mathrm{H} & -3.58128 & -2.84396 & 1.59954 \\ \mathrm{H} & -5.23555 & -2.30828 & 1.94977\end{array}$

[2OPiv- $\left.\alpha \mathrm{Glc}^{\circ} 4-\mathrm{ClOBz}\right]^{-}$(with $4-\mathrm{ClOBz}$ bound at $\mathrm{C}-3$ and $\left.\mathrm{C}-4\right)$

Energy (Hartree/particle): -1876.76253539

$\begin{array}{lc}\text { Zero-point correction }= & 0.430302(\text { Hartree/Particle }) \\ \text { Thermal correction to Energy= } & 0.461722 \\ \text { Thermal correction to Enthalpy= } & 0.462666 \\ \text { Thermal correction to Gibbs Free Energy= } & 0.361587 \\ \text { Sum of electronic and zero-point Energies }= & -1876.332233\end{array}$


Sum of electronic and thermal Energies=

Sum of electronic and thermal Enthalpies $=$

$-1876.300813$

Sum of electronic and thermal Free Energies=

$-1876.299869$

$-1876.400949$

Number of imaginary frequencies: 0

\section{Geometry:}

$\begin{array}{lrrr}\mathrm{C} & 3.74713 & -1.04800 & -0.10080 \\ \mathrm{C} & 2.68084 & -0.03678 & -0.52810 \\ \mathrm{C} & 1.26683 & -0.41625 & -0.10171 \\ \mathrm{O} & 0.39423 & 0.47954 & -0.74553 \\ \mathrm{C} & 0.97042 & -1.89321 & -0.46799 \\ \mathrm{C} & 2.13123 & -2.80688 & -0.04647 \\ \mathrm{C} & 1.95483 & -4.23446 & -0.53669 \\ \mathrm{O} & 2.79826 & -5.18487 & 0.14020 \\ \mathrm{O} & 3.39644 & -2.33505 & -0.55716 \\ \mathrm{O} & -0.17271 & -2.38001 & 0.19290 \\ \mathrm{O} & 2.96591 & 1.27401 & 0.02759 \\ \mathrm{O} & 3.90979 & -0.98355 & 1.30574 \\ \mathrm{H} & 2.16072 & -2.80897 & 1.05509 \\ \mathrm{H} & 4.70534 & -0.82625 & -0.59330 \\ \mathrm{H} & 2.72099 & 0.03755 & -1.61888 \\ \mathrm{H} & 1.19158 & -0.33986 & 0.99561 \\ \mathrm{H} & 0.85814 & -1.93720 & -1.56753 \\ \mathrm{C} & 4.98300 & -1.79228 & 1.76866 \\ \mathrm{C} & 3.82121 & 2.07667 & -0.62585 \\ \mathrm{H} & 0.89599 & -4.50071 & -0.43219 \\ \mathrm{H} & 2.23542 & -4.28958 & -1.59387 \\ \mathrm{H} & -1.00911 & -1.94780 & -0.16272 \\ \mathrm{H} & -0.50553 & 0.46451 & -0.30077 \\ \mathrm{H} & 2.52668 & -5.17651 & 1.06787 \\ \mathrm{O} & 4.45433 & 1.75776 & -1.61367 \\ \mathrm{C} & 3.86471 & 3.46404 & 0.03894 \\ \mathrm{C} & 4.94590 & 4.31623 & -0.63619 \\ \mathrm{C} & 4.17515 & 3.31047 & 1.54055 \\ \mathrm{C} & 2.47967 & 4.11999 & -0.14564 \\ \mathrm{Cl} & -8.77260 & 0.94022 & 0.23835 \\ \mathrm{C} & -6.12882 & 1.54679 & 0.54105 \\ \mathrm{C} & -4.76817 & 1.25216 & 0.45859 \\ \mathrm{C} & -2.82788 & -0.29697 & -0.10289 \\ \mathrm{C} & -4.32293 & 0.01398 & -0.01757 \\ \mathrm{C} & -7.05097 & 0.58188 & 0.13921 \\ \mathrm{O} & -5.27331 & -0.93358 & -0.41375 \\ & -6.63898 & -0.66068 & -0.33950 \\ & -2.51918 & -1.42705 & -0.57310 \\ \mathrm{O} & -2.04542 & 0.60497 & 0.30465\end{array}$




$\begin{array}{lrrr}\mathrm{H} & -6.47506 & 2.50793 & 0.91004 \\ \mathrm{H} & -4.02140 & 1.97985 & 0.76263 \\ \mathrm{H} & -4.91595 & -1.89095 & -0.78166 \\ \mathrm{H} & -7.37723 & -1.39589 & -0.64657 \\ \mathrm{H} & 5.04805 & -1.63973 & 2.85007 \\ \mathrm{H} & 5.93551 & -1.49053 & 1.30121 \\ \mathrm{H} & 4.81093 & -2.85554 & 1.55361 \\ \mathrm{H} & 4.74920 & 4.42613 & -1.70638 \\ \mathrm{H} & 5.93533 & 3.86074 & -0.52470 \\ \mathrm{H} & 4.96707 & 5.31260 & -0.17849 \\ \mathrm{H} & 2.24493 & 4.23977 & -1.20912 \\ \mathrm{H} & 2.47837 & 5.11318 & 0.32062 \\ \mathrm{H} & 1.69247 & 3.51219 & 0.30678 \\ \mathrm{H} & 5.13952 & 2.81156 & 1.69263 \\ \mathrm{H} & 3.40438 & 2.72312 & 2.04425 \\ \mathrm{H} & 4.22558 & 4.30185 & 2.00770\end{array}$

[2OPiv- $\left.\alpha \mathrm{Glc}^{\circ} 4-\mathrm{ClOBz}\right]^{-}$(with $4-\mathrm{ClOBz}$ bound at $\mathrm{C}-4$ and $\mathrm{C}-6$ )

Energy (Hartree/particle): -1876.76622074

Zero-point correction $=$

Thermal correction to Energy=

Thermal correction to Enthalpy=

Thermal correction to Gibbs Free Energy=

Sum of electronic and zero-point Energies $=$

Sum of electronic and thermal Energies=

Sum of electronic and thermal Enthalpies=

Sum of electronic and thermal Free Energies=
0.430967 (Hartree/Particle)

0.462109

0.463053

0.363361

$-1876.335253$

$-1876.304112$

$-1876.303168$

$-1876.402860$

\section{Number of imaginary frequencies: 0}

\section{Geometry:}

$\begin{array}{lrrc}\mathrm{C} & 3.08261 & 1.22751 & 0.80846 \\ \mathrm{C} & 2.91676 & -0.20899 & 0.28241 \\ \mathrm{C} & 1.93464 & -0.25770 & -0.86724 \\ \mathrm{O} & 1.69372 & -1.61294 & -1.24150 \\ \mathrm{C} & 0.61628 & 0.41464 & -0.45827 \\ \mathrm{C} & 0.88321 & 1.84934 & 0.01529 \\ \mathrm{C} & -0.34189 & 2.59832 & 0.56220 \\ \mathrm{O} & -1.10858 & 3.19782 & -0.45394 \\ \mathrm{O} & 1.83607 & 1.79303 & 1.12178 \\ \mathrm{O} & -0.23858 & 0.32058 & -1.57380 \\ \mathrm{O} & 4.18497 & -0.74236 & -0.18792 \\ \mathrm{O} & 3.80965 & 1.96738 & -0.16040\end{array}$




$\begin{array}{lrrr}\mathrm{H} & 1.30773 & 2.43857 & -0.80850 \\ \mathrm{H} & 3.63715 & 1.22263 & 1.75820 \\ \mathrm{H} & 2.56471 & -0.83324 & 1.10843 \\ \mathrm{H} & 2.35181 & 0.30134 & -1.72028 \\ \mathrm{H} & 0.19652 & -0.14361 & 0.39732 \\ \mathrm{C} & 4.13561 & 3.27833 & 0.28021 \\ \mathrm{C} & 5.05970 & -1.20485 & 0.72257 \\ \mathrm{H} & -0.94684 & 1.90888 & 1.17234 \\ \mathrm{H} & 0.04478 & 3.38199 & 1.23438 \\ \mathrm{H} & -1.17903 & 0.16261 & -1.23667 \\ \mathrm{H} & 0.83588 & -1.55836 & -1.70138 \\ \mathrm{H} & -1.92231 & 2.64187 & -0.58550 \\ \mathrm{O} & 4.87233 & -1.20519 & 1.92294 \\ \mathrm{C} & 6.33064 & -1.72578 & 0.02804 \\ \mathrm{C} & 7.29802 & -2.26928 & 1.08600 \\ \mathrm{C} & 6.98685 & -0.55700 & -0.73558 \\ \mathrm{C} & 5.94301 & -2.84535 & -0.95895 \\ \mathrm{Cl} & -9.05616 & -1.68083 & 0.65802 \\ \mathrm{C} & -6.39050 & -1.91762 & 0.12435 \\ \mathrm{C} & -5.12365 & -1.39632 & -0.13727 \\ \mathrm{C} & -3.51478 & 0.54873 & -0.48502 \\ \mathrm{C} & -4.90752 & -0.01506 & -0.19702 \\ \mathrm{C} & -7.45120 & -1.03650 & 0.32756 \\ \mathrm{C} & -5.99243 & 0.84366 & 0.01199 \\ \mathrm{C} & -7.26767 & 0.34432 & 0.27459 \\ \mathrm{O} & -3.41688 & 1.80137 & -0.52771 \\ \mathrm{O} & -2.59765 & -0.30782 & -0.65025 \\ \mathrm{H} & -6.55884 & -2.98963 & 0.17108 \\ \mathrm{H} & -4.27499 & -2.05394 & -0.30067 \\ \mathrm{H} & -5.81235 & 1.91365 & -0.03654 \\ \mathrm{H} & -8.11021 & 1.01035 & 0.43669 \\ \mathrm{H} & 4.75013 & 3.72957 & -0.50426 \\ \mathrm{H} & 4.71057 & 3.24765 & 1.22116 \\ \mathrm{H} & 3.23660 & 3.88803 & 0.43870 \\ \mathrm{H} & 5.45896 & -3.67705 & -0.43471 \\ \mathrm{H} & 6.84514 & -3.22966 & -1.45089 \\ \mathrm{H} & 5.25277 & -2.47806 & -1.72187 \\ \mathrm{H} & 7.25272 & 0.25647 & -0.05074 \\ \mathrm{H} & 6.31210 & -0.15531 & -1.49513 \\ \mathrm{H} & 7.90441 & -0.90673 & -1.22457 \\ \mathrm{H} & 6.20749 & -1.49133 & 1.80289 \\ \mathrm{H} & & -3.09200 & 1.64805\end{array}$

$\left.\left[2 \mathrm{OPiv}-\alpha \mathrm{Glc}^{\circ} 4-\mathrm{ClOBz}\right]^{-}(\mathrm{H1}) \bullet q u i n u c l i d i n e\right]^{\bullet+}($ transition state for HAT) 
Energy (Hartree/particle): -2205.83005982

$\begin{array}{lc}\text { Zero-point correction }= & 0.617756(\text { Hartree/Particle }) \\ \text { Thermal correction to Energy }= & 0.657431 \\ \text { Thermal correction to Enthalpy= } & 0.658375 \\ \text { Thermal correction to Gibbs Free Energy= } & 0.538520 \\ \text { Sum of electronic and zero-point Energies }= & -2205.212304 \\ \text { Sum of electronic and thermal Energies }= & -2205.172629 \\ \text { Sum of electronic and thermal Enthalpies }= & -2205.171685 \\ \text { Sum of electronic and thermal Free Energies }= & -2205.291539\end{array}$

Number of imaginary frequencies: $1,-1389.4384$

$\begin{array}{lrrr}\text { Geometry: } & & \\ \mathrm{C} & 1.87935 & -0.78159 & 0.47675 \\ \mathrm{C} & 1.13111 & 0.01086 & -0.57590 \\ \mathrm{C} & -0.15976 & -0.74844 & -1.03050 \\ \mathrm{O} & -0.69938 & -0.06946 & -2.10118 \\ \mathrm{C} & 0.17809 & -2.20758 & -1.39146 \\ \mathrm{C} & 0.97251 & -2.87331 & -0.26305 \\ \mathrm{C} & 1.48548 & -4.25481 & -0.61451 \\ \mathrm{O} & 2.03651 & -4.95412 & 0.50875 \\ \mathrm{O} & 2.16664 & -2.05825 & 0.06530 \\ \mathrm{O} & -0.98496 & -2.96381 & -1.61640 \\ \mathrm{O} & 0.70811 & 1.28222 & -0.07468 \\ \mathrm{O} & 1.30753 & -0.64938 & 1.73108 \\ \mathrm{H} & 0.33239 & -2.92559 & 0.62867 \\ \mathrm{H} & 3.17710 & -0.25507 & 0.49256 \\ \mathrm{H} & 1.77090 & 0.14651 & -1.45057 \\ \mathrm{H} & -0.84391 & -0.75908 & -0.16758 \\ \mathrm{H} & 0.79568 & -2.19588 & -2.30697 \\ \mathrm{C} & 1.79544 & -1.51574 & 2.76496 \\ \mathrm{C} & 1.34072 & 2.39981 & -0.49641 \\ \mathrm{H} & 0.66115 & -4.81080 & -1.07715 \\ \mathrm{H} & 2.29560 & -4.16154 & -1.34666 \\ \mathrm{H} & -1.79746 & -2.43362 & -1.35869 \\ \mathrm{H} & -1.68277 & 0.19207 & -1.83260 \\ \mathrm{H} & 1.29740 & -5.31970 & 1.01237 \\ \mathrm{O} & 2.38832 & 2.38395 & -1.11692 \\ \mathrm{C} & 0.55774 & 3.65141 & -0.09928 \\ \mathrm{C} & 1.39013 & 4.89597 & -0.43172 \\ \mathrm{C} & 0.23892 & 3.61284 & 1.40911 \\ \mathrm{C} & -0.75762 & 3.65438 & -0.91305 \\ \mathrm{Cl} & -9.20895 & 0.47940 & 1.26612 \\ \mathrm{C} & -6.87876 & 1.23971 & 0.08198\end{array}$




\begin{tabular}{|c|c|c|c|}
\hline $\mathrm{C}$ & -5.59591 & 0.99769 & -0.40465 \\
\hline $\mathrm{C}$ & -3.62897 & -0.53988 & -0.85578 \\
\hline $\mathrm{C}$ & -5.02674 & -0.27921 & -0.33121 \\
\hline $\mathrm{C}$ & -7.59642 & 0.18649 & 0.64861 \\
\hline $\mathrm{C}$ & -5.77010 & -1.31880 & 0.23961 \\
\hline $\mathrm{C}$ & -7.05391 & -1.09590 & 0.73201 \\
\hline $\mathrm{O}$ & -3.18248 & -1.71173 & -0.76218 \\
\hline $\mathrm{O}$ & -3.01757 & 0.46962 & -1.34063 \\
\hline $\mathrm{H}$ & -7.32276 & 2.22874 & 0.02469 \\
\hline $\mathrm{H}$ & -5.01730 & 1.79934 & -0.85267 \\
\hline $\mathrm{H}$ & -5.32297 & -2.30684 & 0.28847 \\
\hline $\mathrm{H}$ & -7.63246 & -1.90114 & 1.17409 \\
\hline $\mathrm{H}$ & 1.03453 & -1.50669 & 3.54726 \\
\hline $\mathrm{H}$ & 2.73658 & -1.11993 & 3.17185 \\
\hline $\mathrm{H}$ & 1.95807 & -2.53283 & 2.39847 \\
\hline $\mathrm{H}$ & 7.98413 & 0.78699 & 0.13829 \\
\hline $\mathrm{C}$ & 6.91713 & 0.55945 & 0.21937 \\
\hline $\mathrm{H}$ & 7.12666 & -1.60222 & 0.20498 \\
\hline $\mathrm{H}$ & 6.31210 & 1.55760 & -1.61224 \\
\hline $\mathrm{H}$ & 6.60389 & 1.57329 & 2.11478 \\
\hline $\mathrm{H}$ & 6.80701 & -0.12004 & -1.84566 \\
\hline $\mathrm{H}$ & 7.25487 & -0.88835 & 1.81269 \\
\hline $\mathrm{H}$ & 6.41774 & 2.62178 & 0.70767 \\
\hline $\mathrm{C}$ & 6.71916 & -0.82530 & 0.86016 \\
\hline $\mathrm{C}$ & 6.26721 & 0.55514 & -1.17430 \\
\hline $\mathrm{C}$ & 6.21652 & 1.61672 & 1.09108 \\
\hline $\mathrm{C}$ & 5.20296 & -1.05146 & 1.08832 \\
\hline $\mathrm{C}$ & 4.79282 & 0.09842 & -1.03287 \\
\hline $\mathrm{C}$ & 4.68997 & 1.34287 & 1.07234 \\
\hline $\mathrm{N}$ & 4.43796 & 0.03251 & 0.41438 \\
\hline $\mathrm{H}$ & 4.84643 & -2.00209 & 0.68639 \\
\hline $\mathrm{H}$ & 4.09472 & 0.79381 & -1.50010 \\
\hline $\mathrm{H}$ & 4.26298 & 1.29272 & 2.07797 \\
\hline $\mathrm{H}$ & 4.62360 & -0.90075 & -1.44126 \\
\hline $\mathrm{H}$ & 4.94076 & -1.01524 & 2.14891 \\
\hline $\mathrm{H}$ & 4.13956 & 2.09124 & 0.50049 \\
\hline $\mathrm{H}$ & -0.55203 & 3.65889 & -1.98851 \\
\hline $\mathrm{H}$ & -1.32489 & 4.55947 & -0.66851 \\
\hline $\mathrm{H}$ & -1.37390 & 2.78094 & -0.68853 \\
\hline $\mathrm{H}$ & 1.63217 & 4.93791 & -1.49703 \\
\hline $\mathrm{H}$ & 2.33099 & 4.90846 & 0.12921 \\
\hline $\mathrm{H}$ & 0.82144 & 5.79386 & -0.16811 \\
\hline $\mathrm{H}$ & -0.38017 & 2.75003 & 1.66336 \\
\hline $\mathrm{H}$ & -0.30313 & 4.52381 & 1.68494 \\
\hline $\mathrm{H}$ & 1.15742 & 3.57181 & 2.00721 \\
\hline
\end{tabular}




\section{$\left.\left[2 \mathrm{OPiv}-\alpha \mathrm{Glc}^{\circ} 4-\mathrm{ClOBz}\right]^{-}(\mathrm{H3}) \bullet q u i n u c l i d i n e\right]^{\bullet+}($ transition state for HAT)}

Energy (Hartree/particle): -2205.85659541

$\begin{array}{lc}\text { Zero-point correction }= & 0.617767 \text { (Hartree/Particle) } \\ \text { Thermal correction to Energy= } & 0.656963 \\ \text { Thermal correction to Enthalpy= } & 0.657907 \\ \text { Thermal correction to Gibbs Free Energy= } & 0.540723 \\ \text { Sum of electronic and zero-point Energies }= & -2205.238828 \\ \text { Sum of electronic and thermal Energies }= & -2205.199632 \\ \text { Sum of electronic and thermal Enthalpies }= & -2205.198688 \\ \text { Sum of electronic and thermal Free Energies }= & -2205.315872\end{array}$

Number of imaginary frequencies: 1, -709.0604

\begin{tabular}{lrcc}
\multicolumn{4}{l}{ Geometry: } \\
$\mathrm{C}$ & 1.87935 & -0.78159 & 0.47675 \\
$\mathrm{C}$ & 1.13111 & 0.01086 & -0.57590 \\
$\mathrm{C}$ & -0.15976 & -0.74844 & -1.03050 \\
$\mathrm{O}$ & -0.69938 & -0.06946 & -2.10118 \\
$\mathrm{C}$ & 0.17809 & -2.20758 & -1.39146 \\
$\mathrm{C}$ & 0.97251 & -2.87331 & -0.26305 \\
$\mathrm{C}$ & 1.48548 & -4.25481 & -0.61451 \\
$\mathrm{O}$ & 2.03651 & -4.95412 & 0.50875 \\
$\mathrm{O}$ & 2.16664 & -2.05825 & 0.06530 \\
$\mathrm{O}$ & -0.98496 & -2.96381 & -1.61640 \\
$\mathrm{O}$ & 0.70811 & 1.28222 & -0.07468 \\
$\mathrm{O}$ & 1.30753 & -0.64938 & 1.73108 \\
$\mathrm{H}$ & 0.33239 & -2.92559 & 0.62867 \\
$\mathrm{H}$ & 3.17710 & -0.25507 & 0.49256 \\
$\mathrm{H}$ & 1.77090 & 0.14651 & -1.45057 \\
$\mathrm{H}$ & -0.84391 & -0.75908 & -0.16758 \\
$\mathrm{H}$ & 0.79568 & -2.19588 & -2.30697 \\
$\mathrm{C}$ & 1.79544 & -1.51574 & 2.76496 \\
$\mathrm{C}$ & 1.34072 & 2.39981 & -0.49641 \\
$\mathrm{H}$ & 0.66115 & -4.81080 & -1.07715 \\
$\mathrm{H}$ & 2.29560 & -4.16154 & -1.34666 \\
$\mathrm{H}$ & -1.79746 & -2.43362 & -1.35869 \\
$\mathrm{H}$ & -1.68277 & 0.19207 & -1.83260 \\
$\mathrm{H}$ & 1.29740 & -5.31970 & 1.01237 \\
$\mathrm{O}$ & 2.38832 & 2.38395 & -1.11692 \\
$\mathrm{C}$ & 0.55774 & 3.65141 & -0.09928 \\
$\mathrm{C}$ & 1.39013 & 4.89597 & -0.43172 \\
$\mathrm{C}$ & 0.23892 & 3.61284 & 1.40911
\end{tabular}




\begin{tabular}{|c|c|c|c|}
\hline $\mathrm{C}$ & -0.75762 & 3.65438 & -0.91305 \\
\hline $\mathrm{Cl}$ & -9.20895 & 0.47940 & 1.26612 \\
\hline $\mathrm{C}$ & -6.87876 & 1.23971 & 0.08198 \\
\hline $\mathrm{C}$ & -5.59591 & 0.99769 & -0.40465 \\
\hline $\mathrm{C}$ & -3.62897 & -0.53988 & -0.85578 \\
\hline $\mathrm{C}$ & -5.02674 & -0.27921 & -0.33121 \\
\hline $\mathrm{C}$ & -7.59642 & 0.18649 & 0.64861 \\
\hline $\mathrm{C}$ & -5.77010 & -1.31880 & 0.23961 \\
\hline $\mathrm{C}$ & -7.05391 & -1.09590 & 0.73201 \\
\hline $\mathrm{O}$ & -3.18248 & -1.71173 & -0.76218 \\
\hline $\mathrm{O}$ & -3.01757 & 0.46962 & -1.34063 \\
\hline $\mathrm{H}$ & -7.32276 & 2.22874 & 0.02469 \\
\hline $\mathrm{H}$ & -5.01730 & 1.79934 & -0.85267 \\
\hline $\mathrm{H}$ & -5.32297 & -2.30684 & 0.28847 \\
\hline $\mathrm{H}$ & -7.63246 & -1.90114 & 1.17409 \\
\hline $\mathrm{H}$ & 1.03453 & -1.50669 & 3.54726 \\
\hline $\mathrm{H}$ & 2.73658 & -1.11993 & 3.17185 \\
\hline $\mathrm{H}$ & 1.95807 & -2.53283 & 2.39847 \\
\hline $\mathrm{H}$ & 7.98413 & 0.78699 & 0.13829 \\
\hline $\mathrm{C}$ & 6.91713 & 0.55945 & 0.21937 \\
\hline $\mathrm{H}$ & 7.12666 & -1.60222 & 0.20498 \\
\hline $\mathrm{H}$ & 6.31210 & 1.55760 & -1.61224 \\
\hline $\mathrm{H}$ & 6.60389 & 1.57329 & 2.11478 \\
\hline $\mathrm{H}$ & 6.80701 & -0.12004 & -1.84566 \\
\hline $\mathrm{H}$ & 7.25487 & -0.88835 & 1.81269 \\
\hline $\mathrm{H}$ & 6.41774 & 2.62178 & 0.70767 \\
\hline $\mathrm{C}$ & 6.71916 & -0.82530 & 0.86016 \\
\hline $\mathrm{C}$ & 6.26721 & 0.55514 & -1.17430 \\
\hline $\mathrm{C}$ & 6.21652 & 1.61672 & 1.09108 \\
\hline $\mathrm{C}$ & 5.20296 & -1.05146 & 1.08832 \\
\hline $\mathrm{C}$ & 4.79282 & 0.09842 & -1.03287 \\
\hline $\mathrm{C}$ & 4.68997 & 1.34287 & 1.07234 \\
\hline $\mathrm{N}$ & 4.43796 & 0.03251 & 0.41438 \\
\hline $\mathrm{H}$ & 4.84643 & -2.00209 & 0.68639 \\
\hline $\mathrm{H}$ & 4.09472 & 0.79381 & -1.50010 \\
\hline $\mathrm{H}$ & 4.26298 & 1.29272 & 2.07797 \\
\hline $\mathrm{H}$ & 4.62360 & -0.90075 & -1.44126 \\
\hline $\mathrm{H}$ & 4.94076 & -1.01524 & 2.14891 \\
\hline $\mathrm{H}$ & 4.13956 & 2.09124 & 0.50049 \\
\hline $\mathrm{H}$ & -0.55203 & 3.65889 & -1.98851 \\
\hline $\mathrm{H}$ & -1.32489 & 4.55947 & -0.66851 \\
\hline $\mathrm{H}$ & -1.37390 & 2.78094 & -0.68853 \\
\hline $\mathrm{H}$ & 1.63217 & 4.93791 & -1.49703 \\
\hline $\mathrm{H}$ & 2.33099 & 4.90846 & 0.12921 \\
\hline $\mathrm{H}$ & 0.82144 & 5.79386 & -0.16811 \\
\hline $\mathrm{H}$ & -0.38017 & 2.75003 & 1.66336 \\
\hline
\end{tabular}




$\begin{array}{lrrr}\mathrm{H} & -0.30313 & 4.52381 & 1.68494 \\ \mathrm{H} & 1.15742 & 3.57181 & 2.00721\end{array}$

$[2 \mathrm{OPiv}-\alpha \mathrm{Glc} \bullet 4-\mathrm{ClOBz}]^{-}(\mathrm{H} 4) \bullet$ quinuclidine ${ }^{++}($transition state for HAT $)$

Energy (Hartree/particle): -2205.85386592

$\begin{array}{lc}\text { Zero-point correction }= & 0.618953 \\ \text { Thermal correction to Energy }= & 0.657726 \\ \text { Thermal correction to Enthalpy }= & 0.658670 \\ \text { Thermal correction to Gibbs Free Energy }= & 0.543321 \\ \text { Sum of electronic and zero-point Energies }= & -2205.234913 \\ \text { Sum of electronic and thermal Energies }= & -2205.196140 \\ \text { Sum of electronic and thermal Enthalpies }= & -2205.195195 \\ \text { Sum of electronic and thermal Free Energies }= & -2205.310545\end{array}$

Number of imaginary frequencies: $1,-924.1700$

\begin{tabular}{lrrr}
\multicolumn{4}{l}{ Geometry: } \\
C & 3.23480 & 1.47511 & 1.06115 \\
$\mathrm{C}$ & 3.08311 & 0.26969 & 0.13019 \\
$\mathrm{C}$ & 2.26232 & 0.61921 & -1.09853 \\
$\mathrm{O}$ & 2.02918 & -0.56725 & -1.85115 \\
$\mathrm{C}$ & 0.93533 & 1.29102 & -0.69667 \\
$\mathrm{C}$ & 1.18658 & 2.45891 & 0.27923 \\
$\mathrm{C}$ & -0.00951 & 3.22902 & 0.84012 \\
$\mathrm{O}$ & -0.59805 & 4.03360 & -0.15182 \\
$\mathrm{O}$ & 1.93992 & 1.96227 & 1.40437 \\
$\mathrm{O}$ & 0.19157 & 1.47870 & -1.79990 \\
$\mathrm{O}$ & 4.37579 & -0.21855 & -0.26920 \\
$\mathrm{O}$ & 4.04081 & 2.43504 & 0.43921 \\
$\mathrm{H}$ & 1.79757 & 3.18417 & -0.28221 \\
$\mathrm{H}$ & 2.58839 & -0.51956 & 0.69303 \\
$\mathrm{H}$ & 2.82285 & 1.34833 & -1.70703 \\
$\mathrm{H}$ & 0.31979 & 0.37106 & 0.01323 \\
$\mathrm{C}$ & 4.40808 & 3.51745 & 1.29797 \\
$\mathrm{C}$ & 4.67195 & -1.51724 & 0.02378 \\
$\mathrm{H}$ & -0.73897 & 2.54049 & 1.28384 \\
$\mathrm{H}$ & 0.38564 & 3.85295 & 1.65841 \\
$\mathrm{H}$ & -0.86977 & 1.67623 & -1.68261 \\
$\mathrm{H}$ & 1.40830 & -0.30428 & -2.54896 \\
$\mathrm{H}$ & -1.52402 & 3.69962 & -0.26876 \\
$\mathrm{O}$ & 3.94507 & -2.24532 & 0.66457 \\
$\mathrm{C}$ & 6.03012 & -1.90682 & -0.56829
\end{tabular}




\begin{tabular}{|c|c|c|c|}
\hline $\mathrm{C}$ & 5.93981 & -1.79756 & -2.10571 \\
\hline $\mathrm{C}$ & 6.35966 & -3.34898 & -0.16290 \\
\hline $\mathrm{C}$ & 7.11398 & -0.94636 & -0.03667 \\
\hline $\mathrm{Cl}$ & -7.75026 & -1.92598 & 0.00404 \\
\hline $\mathrm{C}$ & -5.57770 & -1.03500 & -1.36623 \\
\hline $\mathrm{C}$ & -4.51815 & -0.15602 & -1.57824 \\
\hline $\mathrm{C}$ & -3.10088 & 1.83611 & -0.88974 \\
\hline $\mathrm{C}$ & -4.31053 & 0.93923 & -0.73092 \\
\hline $\mathrm{C}$ & -6.43575 & -0.81412 & -0.28774 \\
\hline $\mathrm{C}$ & -5.19946 & 1.15218 & 0.32952 \\
\hline $\mathrm{C}$ & -6.25954 & 0.27932 & 0.56168 \\
\hline $\mathrm{O}$ & -3.00026 & 2.83098 & -0.14082 \\
\hline $\mathrm{O}$ & -2.23808 & 1.44273 & -1.75245 \\
\hline $\mathrm{H}$ & -5.74203 & -1.88297 & -2.02377 \\
\hline $\mathrm{H}$ & -3.83568 & -0.31236 & -2.40752 \\
\hline $\mathrm{H}$ & -5.03613 & 2.00797 & 0.97728 \\
\hline $\mathrm{H}$ & -6.94338 & 0.43723 & 1.38967 \\
\hline $\mathrm{H}$ & -2.59128 & -3.34890 & 1.84027 \\
\hline $\mathrm{C}$ & -1.94850 & -2.54794 & 1.46185 \\
\hline $\mathrm{H}$ & -0.50389 & -2.63402 & 3.08118 \\
\hline $\mathrm{H}$ & -3.46075 & -0.98824 & 1.46856 \\
\hline $\mathrm{H}$ & -1.49507 & -3.51617 & -0.42856 \\
\hline $\mathrm{H}$ & -2.60467 & -1.15730 & 3.00487 \\
\hline $\mathrm{H}$ & -0.13188 & -3.71900 & 1.73967 \\
\hline $\mathrm{H}$ & -2.93871 & -2.49411 & -0.46995 \\
\hline $\mathrm{C}$ & -0.51554 & -2.72494 & 1.98980 \\
\hline $\mathrm{C}$ & -2.48181 & -1.18146 & 1.91719 \\
\hline $\mathrm{C}$ & -1.92183 & -2.57179 & -0.07364 \\
\hline $\mathrm{C}$ & 0.39530 & -1.63779 & 1.34946 \\
\hline $\mathrm{C}$ & -1.47342 & -0.08669 & 1.47745 \\
\hline $\mathrm{C}$ & -1.07312 & -1.37268 & -0.57667 \\
\hline $\mathrm{N}$ & -0.44893 & -0.68745 & 0.58623 \\
\hline $\mathrm{H}$ & 0.93959 & -1.06744 & 2.10563 \\
\hline $\mathrm{H}$ & -1.96489 & 0.72176 & 0.94039 \\
\hline $\mathrm{H}$ & -0.25604 & -1.68840 & -1.22695 \\
\hline $\mathrm{H}$ & -0.93825 & 0.34504 & 2.32666 \\
\hline $\mathrm{H}$ & 1.11830 & -2.07007 & 0.65631 \\
\hline $\mathrm{H}$ & -1.67180 & -0.62951 & -1.10495 \\
\hline $\mathrm{H}$ & 5.08096 & 4.15508 & 0.72086 \\
\hline $\mathrm{H}$ & 4.93148 & 3.14348 & 2.19080 \\
\hline $\mathrm{H}$ & 3.53031 & 4.09525 & 1.61197 \\
\hline $\mathrm{H}$ & 3.67313 & 1.16427 & 2.02224 \\
\hline $\mathrm{H}$ & 6.41280 & -3.45287 & 0.92492 \\
\hline $\mathrm{H}$ & 7.32856 & -3.63371 & -0.58713 \\
\hline $\mathrm{H}$ & 5.60083 & -4.04600 & -0.52945 \\
\hline $\mathrm{H}$ & 7.17976 & -0.99503 & 1.05625 \\
\hline
\end{tabular}




$\begin{array}{llll}\mathrm{H} & 6.90666 & 0.08661 & -0.32628 \\ \mathrm{H} & 8.08758 & -1.23619 & -0.44729 \\ \mathrm{H} & 5.14743 & -2.44327 & -2.49883 \\ \mathrm{H} & 6.89154 & -2.11403 & -2.54696 \\ \mathrm{H} & 5.73328 & -0.77113 & -2.41825\end{array}$

\section{$\left.[2 \mathrm{OPiv}-\alpha \mathrm{Glc} 4-\mathrm{ClOBz}]^{-}(\mathrm{H5}) \bullet q u i n u c l i d i n e\right]^{\bullet+}($ transition state for HAT)}

Energy (Hartree/particle): -2205.84292215

$\begin{array}{lc}\text { Zero-point correction }= & 0.618918 \text { (Hartree/Particle) } \\ \text { Thermal correction to Energy= } & 0.657978 \\ \text { Thermal correction to Enthalpy= } & 0.658922 \\ \text { Thermal correction to Gibbs Free Energy= } & 0.541072 \\ \text { Sum of electronic and zero-point Energies }= & -2205.224004 \\ \text { Sum of electronic and thermal Energies }= & -2205.184944 \\ \text { Sum of electronic and thermal Enthalpies }= & -2205.184000 \\ \text { Sum of electronic and thermal Free Energies }= & -2205.301850\end{array}$

Number of imaginary frequencies: $1,-1043.9537$

\begin{tabular}{lrrr}
\multicolumn{4}{l}{ Geometry: } \\
$\mathrm{C}$ & 3.23480 & 1.47511 & 1.06115 \\
$\mathrm{C}$ & 3.08311 & 0.26969 & 0.13019 \\
$\mathrm{C}$ & 2.26232 & 0.61921 & -1.09853 \\
$\mathrm{O}$ & 2.02918 & -0.56725 & -1.85115 \\
$\mathrm{C}$ & 0.93533 & 1.29102 & -0.69667 \\
$\mathrm{C}$ & 1.18658 & 2.45891 & 0.27923 \\
$\mathrm{C}$ & -0.00951 & 3.22902 & 0.84012 \\
$\mathrm{O}$ & -0.59805 & 4.03360 & -0.15182 \\
$\mathrm{O}$ & 1.93992 & 1.96227 & 1.40437 \\
$\mathrm{O}$ & 0.19157 & 1.47870 & -1.79990 \\
$\mathrm{O}$ & 4.37579 & -0.21855 & -0.26920 \\
$\mathrm{O}$ & 4.04081 & 2.43504 & 0.43921 \\
$\mathrm{H}$ & 1.79757 & 3.18417 & -0.28221 \\
$\mathrm{H}$ & 2.58839 & -0.51956 & 0.69303 \\
$\mathrm{H}$ & 2.82285 & 1.34833 & -1.70703 \\
$\mathrm{H}$ & 0.31979 & 0.37106 & 0.01323 \\
$\mathrm{C}$ & 4.40808 & 3.51745 & 1.29797 \\
$\mathrm{C}$ & 4.67195 & -1.51724 & 0.02378 \\
$\mathrm{H}$ & -0.73897 & 2.54049 & 1.28384 \\
$\mathrm{H}$ & 0.38564 & 3.85295 & 1.65841 \\
$\mathrm{H}$ & -0.86977 & 1.67623 & -1.68261 \\
$\mathrm{H}$ & 1.40830 & -0.30428 & -2.54896 \\
& & &
\end{tabular}




\begin{tabular}{|c|c|c|c|}
\hline $\mathrm{H}$ & -1.52402 & 3.69962 & -0.26876 \\
\hline $\mathrm{O}$ & 3.94507 & -2.24532 & 0.66457 \\
\hline $\mathrm{C}$ & 6.03012 & -1.90682 & -0.56829 \\
\hline $\mathrm{C}$ & 5.93981 & -1.79756 & -2.10571 \\
\hline $\mathrm{C}$ & 6.35966 & -3.34898 & -0.16290 \\
\hline $\mathrm{C}$ & 7.11398 & -0.94636 & -0.03667 \\
\hline $\mathrm{Cl}$ & -7.75026 & -1.92598 & 0.00404 \\
\hline $\mathrm{C}$ & -5.57770 & -1.03500 & -1.36623 \\
\hline $\mathrm{C}$ & -4.51815 & -0.15602 & -1.57824 \\
\hline $\mathrm{C}$ & -3.10088 & 1.83611 & -0.88974 \\
\hline $\mathrm{C}$ & -4.31053 & 0.93923 & -0.73092 \\
\hline $\mathrm{C}$ & -6.43575 & -0.81412 & -0.28774 \\
\hline $\mathrm{C}$ & -5.19946 & 1.15218 & 0.32952 \\
\hline $\mathrm{C}$ & -6.25954 & 0.27932 & 0.56168 \\
\hline $\mathrm{O}$ & -3.00026 & 2.83098 & -0.14082 \\
\hline $\mathrm{O}$ & -2.23808 & 1.44273 & -1.75245 \\
\hline $\mathrm{H}$ & -5.74203 & -1.88297 & -2.02377 \\
\hline $\mathrm{H}$ & -3.83568 & -0.31236 & -2.40752 \\
\hline $\mathrm{H}$ & -5.03613 & 2.00797 & 0.97728 \\
\hline $\mathrm{H}$ & -6.94338 & 0.43723 & 1.38967 \\
\hline $\mathrm{H}$ & -2.59128 & -3.34890 & 1.84027 \\
\hline $\mathrm{C}$ & -1.94850 & -2.54794 & 1.46185 \\
\hline $\mathrm{H}$ & -0.50389 & -2.63402 & 3.08118 \\
\hline $\mathrm{H}$ & -3.46075 & -0.98824 & 1.46856 \\
\hline $\mathrm{H}$ & -1.49507 & -3.51617 & -0.42856 \\
\hline $\mathrm{H}$ & -2.60467 & -1.15730 & 3.00487 \\
\hline $\mathrm{H}$ & -0.13188 & -3.71900 & 1.73967 \\
\hline $\mathrm{H}$ & -2.93871 & -2.49411 & -0.46995 \\
\hline $\mathrm{C}$ & -0.51554 & -2.72494 & 1.98980 \\
\hline $\mathrm{C}$ & -2.48181 & -1.18146 & 1.91719 \\
\hline $\mathrm{C}$ & -1.92183 & -2.57179 & -0.07364 \\
\hline $\mathrm{C}$ & 0.39530 & -1.63779 & 1.34946 \\
\hline $\mathrm{C}$ & -1.47342 & -0.08669 & 1.47745 \\
\hline $\mathrm{C}$ & -1.07312 & -1.37268 & -0.57667 \\
\hline $\mathrm{N}$ & -0.44893 & -0.68745 & 0.58623 \\
\hline $\mathrm{H}$ & 0.93959 & -1.06744 & 2.10563 \\
\hline $\mathrm{H}$ & -1.96489 & 0.72176 & 0.94039 \\
\hline $\mathrm{H}$ & -0.25604 & -1.68840 & -1.22695 \\
\hline $\mathrm{H}$ & -0.93825 & 0.34504 & 2.32666 \\
\hline $\mathrm{H}$ & 1.11830 & -2.07007 & 0.65631 \\
\hline $\mathrm{H}$ & -1.67180 & -0.62951 & -1.10495 \\
\hline $\mathrm{H}$ & 5.08096 & 4.15508 & 0.72086 \\
\hline $\mathrm{H}$ & 4.93148 & 3.14348 & 2.19080 \\
\hline $\mathrm{H}$ & 3.53031 & 4.09525 & 1.61197 \\
\hline $\mathrm{H}$ & 3.67313 & 1.16427 & 2.02224 \\
\hline $\mathrm{H}$ & 6.41280 & -3.45287 & 0.92492 \\
\hline
\end{tabular}




$\begin{array}{llrr}\mathrm{H} & 7.32856 & -3.63371 & -0.58713 \\ \mathrm{H} & 5.60083 & -4.04600 & -0.52945 \\ \mathrm{H} & 7.17976 & -0.99503 & 1.05625 \\ \mathrm{H} & 6.90666 & 0.08661 & -0.32628 \\ \mathrm{H} & 8.08758 & -1.23619 & -0.44729 \\ \mathrm{H} & 5.14743 & -2.44327 & -2.49883 \\ \mathrm{H} & 6.89154 & -2.11403 & -2.54696 \\ \mathrm{H} & 5.73328 & -0.77113 & -2.41825\end{array}$

\section{[2-OPiv- $\beta$-glu]}

Energy (Hartree/particle): -996.889258613

Zero-point correction $=$

Thermal correction to Energy=

Thermal correction to Enthalpy=

Thermal correction to Gibbs Free Energy=

Sum of electronic and zero-point Energies $=$

Sum of electronic and thermal Energies=

Sum of electronic and thermal Enthalpies=

Sum of electronic and thermal Free Energies=
0.339043 (Hartree/Particle)

0.360783

0.361727

0.287535

$-996.550216$

$-996.528476$

$-996.527532$

$-996.601724$

Number of imaginary frequencies: 0

\section{Geometry:}

$\begin{array}{lrrr}\mathrm{C} & -0.63604 & 1.21838 & -0.17913 \\ \mathrm{C} & -0.01548 & -0.09795 & 0.29777 \\ \mathrm{C} & -0.85055 & -1.27869 & -0.17706 \\ \mathrm{O} & -0.31325 & -2.47030 & 0.38207 \\ \mathrm{C} & -2.31586 & -1.09212 & 0.21162 \\ \mathrm{C} & -2.82904 & 0.27851 & -0.25625 \\ \mathrm{C} & -4.23999 & 0.59297 & 0.24831 \\ \mathrm{O} & -5.21296 & -0.36945 & -0.19076 \\ \mathrm{O} & -1.99667 & 1.31066 & 0.26846 \\ \mathrm{O} & -3.03041 & -2.17760 & -0.38135 \\ \mathrm{O} & 1.29474 & -0.20655 & -0.28462 \\ \mathrm{H} & -2.81870 & 0.29773 & -1.36326 \\ \mathrm{H} & 0.06836 & -0.08711 & 1.38767 \\ \mathrm{H} & -0.80111 & -1.32112 & -1.28001 \\ \mathrm{H} & -2.39139 & -1.13086 & 1.31154 \\ \mathrm{C} & 2.37236 & -0.20793 & 0.55789 \\ \mathrm{H} & -4.24871 & 0.55144 & 1.34193 \\ \mathrm{H} & -4.52008 & 1.61001 & -0.05748 \\ \mathrm{H} & -3.97346 & -2.00761 & -0.21710 \\ \mathrm{H} & -0.93514 & -3.17794 & 0.15746\end{array}$




$\begin{array}{lrrr}\mathrm{H} & -5.35715 & -0.23698 & -1.13782 \\ \mathrm{O} & 2.28786 & -0.14354 & 1.76014 \\ \mathrm{C} & 3.67600 & -0.30061 & -0.24561 \\ \mathrm{C} & 4.86043 & -0.31326 & 0.72883 \\ \mathrm{C} & 3.77554 & 0.92447 & -1.17814 \\ \mathrm{C} & 3.66582 & -1.59896 & -1.07908 \\ \mathrm{H} & -0.63065 & 1.26093 & -1.28814 \\ \mathrm{O} & 0.08336 & 2.26905 & 0.35809 \\ \mathrm{C} & -0.20271 & 3.53729 & -0.23448 \\ \mathrm{H} & 0.49180 & 4.25049 & 0.21468 \\ \mathrm{H} & -1.23415 & 3.84852 & -0.03010 \\ \mathrm{H} & -0.03934 & 3.50378 & -1.32262 \\ \mathrm{H} & 5.79692 & -0.37902 & 0.16386 \\ \mathrm{H} & 4.80259 & -1.16790 & 1.40882 \\ \mathrm{H} & 4.88227 & 0.59581 & 1.33664 \\ \mathrm{H} & 4.61187 & -1.68745 & -1.62540 \\ \mathrm{H} & 2.84461 & -1.60251 & -1.80005 \\ \mathrm{H} & 3.55940 & -2.47722 & -0.43344 \\ \mathrm{H} & 4.72551 & 0.89081 & -1.72365 \\ \mathrm{H} & 3.74408 & 1.85712 & -0.60405 \\ \mathrm{H} & 2.95826 & 0.93814 & -1.90390\end{array}$

\section{[2-OPiv- $\beta$-glu(H1)•quinuclidine $]^{\bullet+}($ transition state for HAT)}

Energy (Hartree/particle): -1325.86434685

Zero-point correction $=$

Thermal correction to Energy=

Thermal correction to Enthalpy=

Thermal correction to Gibbs Free Energy=

Sum of electronic and zero-point Energies=

Sum of electronic and thermal Energies=

Sum of electronic and thermal Enthalpies=

Sum of electronic and thermal Free Energies=
0.527758 (Hartree/Particle)

0.557665

0.558609

0.464899

$-1325.336589$

$-1325.306682$

$-1325.305738$

$-1325.399448$

Number of imaginary frequencies: $1,-342.3873$

\section{Geometry:}

$\begin{array}{llll}\mathrm{C} & -0.65755 & -0.48863 & 1.11970 \\ \mathrm{C} & 0.11262 & -1.47424 & 0.21610 \\ \mathrm{C} & -0.65839 & -1.74394 & -1.06618 \\ \mathrm{O} & 0.01693 & -2.77520 & -1.75701 \\ \mathrm{C} & -2.10633 & -2.12517 & -0.75529 \\ \mathrm{C} & -2.77273 & -1.05723 & 0.12466 \\ \mathrm{C} & -4.14280 & -1.46960 & 0.66081\end{array}$




\begin{tabular}{|c|c|c|c|}
\hline $\mathrm{O}$ & -4.99257 & -1.69558 & -0.46614 \\
\hline $\mathrm{O}$ & -1.98491 & -0.80540 & 1.31589 \\
\hline $\mathrm{O}$ & -2.75069 & -2.23702 & -2.01357 \\
\hline $\mathrm{O}$ & 1.38958 & -0.92380 & -0.10420 \\
\hline $\mathrm{H}$ & -2.86189 & -0.12713 & -0.45491 \\
\hline $\mathrm{H}$ & 0.25481 & -2.40054 & 0.78632 \\
\hline $\mathrm{H}$ & -0.68630 & -0.82556 & -1.67696 \\
\hline $\mathrm{H}$ & -2.11006 & -3.08638 & -0.21341 \\
\hline $\mathrm{C}$ & 2.49531 & -1.58913 & 0.42283 \\
\hline $\mathrm{H}$ & -4.02427 & -2.38024 & 1.26591 \\
\hline $\mathrm{H}$ & -4.53697 & -0.67025 & 1.30428 \\
\hline $\mathrm{H}$ & -3.70006 & -2.36916 & -1.84764 \\
\hline $\mathrm{H}$ & -0.55539 & -3.05027 & -2.48968 \\
\hline $\mathrm{H}$ & -5.83166 & -2.06142 & -0.15720 \\
\hline $\mathrm{O}$ & 2.38385 & -2.47937 & 1.22340 \\
\hline $\mathrm{C}$ & 3.79605 & -1.08211 & -0.19584 \\
\hline $\mathrm{C}$ & 3.84143 & 0.45617 & -0.23693 \\
\hline $\mathrm{C}$ & 3.85479 & -1.64777 & -1.63498 \\
\hline $\mathrm{C}$ & 4.97607 & -1.61747 & 0.62819 \\
\hline $\mathrm{H}$ & -0.60303 & 0.63048 & 0.52045 \\
\hline $\mathrm{O}$ & 0.01338 & -0.30108 & 2.29264 \\
\hline $\mathrm{C}$ & -0.73391 & 0.09139 & 3.46226 \\
\hline $\mathrm{H}$ & 0.01771 & 0.33758 & 4.21208 \\
\hline $\mathrm{H}$ & -1.36092 & -0.73518 & 3.80699 \\
\hline $\mathrm{H}$ & -1.36555 & 0.96169 & 3.25053 \\
\hline $\mathrm{H}$ & 0.20685 & 5.37905 & -1.15020 \\
\hline $\mathrm{C}$ & 0.02179 & 4.35890 & -0.80242 \\
\hline $\mathrm{H}$ & -0.20787 & 3.59549 & -2.83112 \\
\hline $\mathrm{H}$ & -1.73141 & 4.95306 & 0.34682 \\
\hline $\mathrm{H}$ & 1.96196 & 4.21475 & 0.17564 \\
\hline $\mathrm{H}$ & -2.10173 & 4.34714 & -1.26808 \\
\hline $\mathrm{H}$ & 1.41178 & 3.39001 & -2.16175 \\
\hline $\mathrm{H}$ & 0.65067 & 4.70602 & 1.24900 \\
\hline $\mathrm{C}$ & 0.34535 & 3.35389 & -1.91898 \\
\hline $\mathrm{C}$ & -1.45348 & 4.20230 & -0.39853 \\
\hline $\mathrm{C}$ & 0.90747 & 4.04730 & 0.41374 \\
\hline $\mathrm{C}$ & -0.04394 & 1.92822 & -1.43097 \\
\hline $\mathrm{C}$ & -1.65931 & 2.77428 & 0.19039 \\
\hline $\mathrm{C}$ & 0.69153 & 2.55917 & 0.81348 \\
\hline $\mathrm{N}$ & -0.41468 & 1.99416 & 0.00320 \\
\hline $\mathrm{H}$ & -0.90877 & 1.53689 & -1.97280 \\
\hline $\mathrm{H}$ & -1.87388 & 2.80033 & 1.26181 \\
\hline $\mathrm{H}$ & 1.57244 & 1.94560 & 0.62551 \\
\hline $\mathrm{H}$ & -2.47199 & 2.24180 & -0.30989 \\
\hline $\mathrm{H}$ & 0.77613 & 1.21535 & -1.52890 \\
\hline $\mathrm{H}$ & 0.42231 & 2.45308 & 1.86630 \\
\hline
\end{tabular}




$\begin{array}{lrrr}\mathrm{H} & 4.79154 & -1.33102 & -2.10522 \\ \mathrm{H} & 3.01832 & -1.28810 & -2.24068 \\ \mathrm{H} & 3.82790 & -2.74146 & -1.62572 \\ \mathrm{H} & 3.06195 & 0.86543 & -0.88572 \\ \mathrm{H} & 4.80987 & 0.77600 & -0.63419 \\ \mathrm{H} & 3.73499 & 0.88333 & 0.76682 \\ \mathrm{H} & 5.91519 & -1.29392 & 0.16860 \\ \mathrm{H} & 4.96584 & -2.70886 & 0.66886 \\ \mathrm{H} & 4.94580 & -1.24106 & 1.65542\end{array}$

\section{[2-OPiv- $\beta$-glu(H2)•quinuclidine $]^{\bullet+}($ transition state for HAT)}

Energy (Hartree/particle): -1325.85789593

$\begin{array}{lc}\text { Zero-point correction }= & 0.527206 \text { (Hartree/Particle) } \\ \text { Thermal correction to Energy }= & 0.557055 \\ \text { Thermal correction to Enthalpy= } & 0.557999 \\ \text { Thermal correction to Gibbs Free Energy= } & 0.466231 \\ \text { Sum of electronic and zero-point Energies }= & -1325.330690 \\ \text { Sum of electronic and thermal Energies }= & -1325.300841 \\ \text { Sum of electronic and thermal Enthalpies }= & -1325.299897 \\ \text { Sum of electronic and thermal Free Energies }= & -1325.391665\end{array}$

Number of imaginary frequencies: $1,-1547.5565$

\begin{tabular}{lccc}
\multicolumn{4}{l}{ Geometry: } \\
C & -0.65755 & -0.48863 & 1.11970 \\
$\mathrm{C}$ & 0.11262 & -1.47424 & 0.21610 \\
$\mathrm{C}$ & -0.65839 & -1.74394 & -1.06618 \\
$\mathrm{O}$ & 0.01693 & -2.77520 & -1.75701 \\
$\mathrm{C}$ & -2.10633 & -2.12517 & -0.75529 \\
$\mathrm{C}$ & -2.77273 & -1.05723 & 0.12466 \\
$\mathrm{C}$ & -4.14280 & -1.46960 & 0.66081 \\
$\mathrm{O}$ & -4.99257 & -1.69558 & -0.46614 \\
$\mathrm{O}$ & -1.98491 & -0.80540 & 1.31589 \\
$\mathrm{O}$ & -2.75069 & -2.23702 & -2.01357 \\
$\mathrm{O}$ & 1.38958 & -0.92380 & -0.10420 \\
$\mathrm{H}$ & -2.86189 & -0.12713 & -0.45491 \\
$\mathrm{H}$ & 0.25481 & -2.40054 & 0.78632 \\
$\mathrm{H}$ & -0.68630 & -0.82556 & -1.67696 \\
$\mathrm{H}$ & -2.11006 & -3.08638 & -0.21341 \\
$\mathrm{C}$ & 2.49531 & -1.58913 & 0.42283 \\
$\mathrm{H}$ & -4.02427 & -2.38024 & 1.26591 \\
$\mathrm{H}$ & -4.53697 & -0.67025 & 1.30428 \\
$\mathrm{H}$ & -3.70006 & -2.36916 & -1.84764
\end{tabular}




$\begin{array}{lrrr}\mathrm{H} & -0.55539 & -3.05027 & -2.48968 \\ \mathrm{H} & -5.83166 & -2.06142 & -0.15720 \\ \mathrm{O} & 2.38385 & -2.47937 & 1.22340 \\ \mathrm{C} & 3.79605 & -1.08211 & -0.19584 \\ \mathrm{C} & 3.84143 & 0.45617 & -0.23693 \\ \mathrm{C} & 3.85479 & -1.64777 & -1.63498 \\ \mathrm{C} & 4.97607 & -1.61747 & 0.62819 \\ \mathrm{H} & -0.60303 & 0.63048 & 0.52045 \\ \mathrm{O} & 0.01338 & -0.30108 & 2.29264 \\ \mathrm{C} & -0.73391 & 0.09139 & 3.46226 \\ \mathrm{H} & 0.01771 & 0.33758 & 4.21208 \\ \mathrm{H} & -1.36092 & -0.73518 & 3.80699 \\ \mathrm{H} & -1.36555 & 0.96169 & 3.25053 \\ \mathrm{H} & 0.20685 & 5.37905 & -1.15020 \\ \mathrm{C} & 0.02179 & 4.35890 & -0.80242 \\ \mathrm{H} & -0.20787 & 3.59549 & -2.83112 \\ \mathrm{H} & -1.73141 & 4.95306 & 0.34682 \\ \mathrm{H} & 1.96196 & 4.21475 & 0.17564 \\ \mathrm{H} & -2.10173 & 4.34714 & -1.26808 \\ \mathrm{H} & 1.41178 & 3.39001 & -2.16175 \\ \mathrm{H} & 0.65067 & 4.70602 & 1.24900 \\ \mathrm{C} & 0.34535 & 3.35389 & -1.91898 \\ \mathrm{C} & -1.45348 & 4.20230 & -0.39853 \\ \mathrm{C} & 0.90747 & 4.04730 & 0.41374 \\ \mathrm{C} & -0.04394 & 1.92822 & -1.43097 \\ \mathrm{C} & -1.65931 & 2.77428 & 0.19039 \\ \mathrm{C} & 0.69153 & 2.55917 & 0.81348 \\ \mathrm{~N} & -0.41468 & 1.99416 & 0.00320 \\ \mathrm{H} & -0.90877 & 1.53689 & -1.97280 \\ \mathrm{H} & -1.87388 & 2.80033 & 1.26181 \\ \mathrm{H} & 1.57244 & 1.94560 & 0.62551 \\ \mathrm{H} & -2.47199 & 2.24180 & -0.30989 \\ \mathrm{H} & 0.77613 & 1.21535 & -1.52890 \\ \mathrm{H} & 0.42231 & 2.45308 & 1.86630 \\ \mathrm{H} & 4.79154 & -1.33102 & -2.10522 \\ \mathrm{H} & 3.01832 & -1.28810 & -2.24068 \\ \mathrm{H} & 3.82790 & -2.74146 & -1.62572 \\ \mathrm{H} & 3.06195 & 0.86543 & -0.88572 \\ \mathrm{H} & 4.80987 & 0.77600 & -0.63419 \\ \mathrm{H} & 5.73499 & 0.88333 & 0.76682 \\ \mathrm{H} & 4.96584 & -2.70886 & 0.66886 \\ \mathrm{H} & & -1.24106 & 1.65542\end{array}$




\section{[2-OPiv- $\beta$-glu(H3)•quinuclidine $]^{++}($transition state for HAT)}

Energy (Hartree/particle): -1325.86558253

$\begin{array}{lc}\text { Zero-point correction }= & 0.527663 \text { (Hartree/Particle) } \\ \text { Thermal correction to Energy= } & 0.557319 \\ \text { Thermal correction to Enthalpy= } & 0.558263 \\ \text { Thermal correction to Gibbs Free Energy= } & 0.465776 \\ \text { Sum of electronic and zero-point Energies }= & -1325.337919 \\ \text { Sum of electronic and thermal Energies }= & -1325.308263 \\ \text { Sum of electronic and thermal Enthalpies }= & -1325.307319 \\ \text { Sum of electronic and thermal Free Energies }= & -1325.399806\end{array}$

Number of imaginary frequencies: $1,-921.1548$

\section{Geometry:}

$\begin{array}{lrrr}\mathrm{C} & 0.12066 & -1.37116 & 1.03761 \\ \mathrm{C} & -0.17473 & -0.71683 & -0.32430 \\ \mathrm{C} & 0.74374 & -1.21286 & -1.43230 \\ \mathrm{O} & 0.66982 & -0.29838 & -2.52290 \\ \mathrm{C} & 2.19573 & -1.45626 & -1.00261 \\ \mathrm{C} & 2.26761 & -2.12248 & 0.37867 \\ \mathrm{C} & 3.68393 & -2.19271 & 0.94151 \\ \mathrm{O} & 4.47530 & -2.94532 & 0.01651 \\ \mathrm{O} & 1.51465 & -1.32330 & 1.30593 \\ \mathrm{O} & 2.75673 & -2.23830 & -2.04482 \\ \mathrm{O} & -1.48764 & -0.90098 & -0.74262 \\ \mathrm{H} & 1.84639 & -3.13913 & 0.31844 \\ \mathrm{H} & 0.09144 & 0.58549 & -0.14228 \\ \mathrm{H} & 0.34465 & -2.19540 & -1.74154 \\ \mathrm{H} & 2.71132 & -0.48634 & -0.92936 \\ \mathrm{C} & -2.59203 & -0.24869 & -0.18145 \\ \mathrm{H} & 4.07329 & -1.16947 & 1.05939 \\ \mathrm{H} & 3.65732 & -2.67222 & 1.92927 \\ \mathrm{H} & 3.61814 & -2.56356 & -1.72876 \\ \mathrm{H} & 1.16706 & -0.69499 & -3.25376 \\ \mathrm{H} & 5.38282 & -2.99610 & 0.34241 \\ \mathrm{O} & -2.49438 & 0.83624 & 0.32524 \\ \mathrm{C} & -3.85521 & -1.07443 & -0.37077 \\ \mathrm{C} & -3.68085 & -2.40379 & 0.39785 \\ \mathrm{C} & -4.06569 & -1.35679 & -1.87505 \\ \mathrm{C} & -5.04713 & -0.28955 & 0.19331 \\ \mathrm{H} & -0.18936 & -2.43662 & 0.96308 \\ \mathrm{O} & -0.57473 & -0.72491 & 2.03474 \\ \mathrm{C} & -0.64703 & -1.45831 & 3.27227\end{array}$




$\begin{array}{rrrr}\mathrm{H} & -1.29959 & -0.88013 & 3.92785 \\ \mathrm{H} & 0.34467 & -1.55949 & 3.72445 \\ \mathrm{H} & -1.08119 & -2.45262 & 3.10149 \\ \mathrm{H} & 1.33268 & 5.38982 & 0.20387 \\ \mathrm{C} & 1.06128 & 4.33267 & 0.13282 \\ \mathrm{H} & 0.76491 & 4.18384 & 2.28888 \\ \mathrm{H} & 2.98656 & 3.80802 & -0.74717 \\ \mathrm{H} & -0.63357 & 4.76789 & -1.16749 \\ \mathrm{H} & 2.88525 & 3.52217 & 0.99234 \\ \mathrm{H} & -0.72450 & 4.40662 & 1.36769 \\ \mathrm{H} & 0.82003 & 4.25063 & -2.02512 \\ \mathrm{C} & 0.24881 & 3.90634 & 1.36499 \\ \mathrm{C} & 2.32538 & 3.46456 & 0.05368 \\ \mathrm{C} & 0.21795 & 4.08265 & -1.12658 \\ \mathrm{C} & 0.05550 & 2.36332 & 1.33136 \\ \mathrm{C} & 1.89932 & 1.99559 & -0.22814 \\ \mathrm{C} & -0.30669 & 2.61962 & -1.09242 \\ \mathrm{~N} & 0.43079 & 1.88167 & -0.02706 \\ \mathrm{H} & 0.70409 & 1.84569 & 2.03987 \\ \mathrm{H} & 2.10364 & 1.69478 & -1.25656 \\ \mathrm{H} & -1.36324 & 2.56480 & -0.83635 \\ \mathrm{H} & 2.37962 & 1.29156 & 0.45340 \\ \mathrm{H} & -0.97298 & 2.06364 & 1.51693 \\ \mathrm{H} & -0.14003 & 2.08919 & -2.03068 \\ \mathrm{H} & -4.16128 & -0.42460 & -2.44133 \\ \mathrm{H} & -4.99238 & -1.92536 & -2.00013 \\ \mathrm{H} & -3.24317 & -1.93924 & -2.29674 \\ \mathrm{H} & -5.17819 & 0.66240 & -0.32863 \\ \mathrm{H} & -4.91679 & -0.07762 & 1.25826 \\ \mathrm{H} & -5.95920 & -0.88031 & 0.06697 \\ \mathrm{H} & -4.60291 & -2.98693 & 0.31346 \\ \mathrm{H} & -3.49041 & -2.22317 & 1.46116 \\ \mathrm{H} & -2.86182 & -3.00064 & -0.01345 \\ & & & \\ & & \end{array}$

\section{[2-OPiv- $\beta$-glu(H4)•quinuclidine $]^{\bullet+}($ transition state for HAT)}

Energy (Hartree/particle): -1325.86841195

Zero-point correction $=$

Thermal correction to Energy=

Thermal correction to Enthalpy=

Thermal correction to Gibbs Free Energy=

Sum of electronic and zero-point Energies $=$

Sum of electronic and thermal Energies=

$$
0.527620 \text { (Hartree/Particle) }
$$

0.557439

0.558383

0.465399

$-1325.340792$

$-1325.310973$ 
Sum of electronic and thermal Enthalpies $=$

$-1325.310029$

Sum of electronic and thermal Free Energies=

$-1325.403013$

Number of imaginary frequencies: $1,-1066.5780$

\section{Geometry:}

\begin{tabular}{lrrr}
$\mathrm{C}$ & 0.83827 & 1.87223 & 0.80206 \\
$\mathrm{C}$ & 1.02575 & 0.67419 & -0.13641 \\
$\mathrm{C}$ & 0.32942 & 0.90248 & -1.47601 \\
$\mathrm{O}$ & 0.46455 & -0.25574 & -2.27415 \\
$\mathrm{C}$ & -1.13311 & 1.27598 & -1.21453 \\
$\mathrm{C}$ & -1.25397 & 2.45189 & -0.23652 \\
$\mathrm{C}$ & -2.69531 & 2.80828 & 0.14493 \\
$\mathrm{O}$ & -3.51928 & 2.97322 & -1.02601 \\
$\mathrm{O}$ & -0.58293 & 2.13357 & 0.96765 \\
$\mathrm{O}$ & -1.84826 & 1.37378 & -2.38233 \\
$\mathrm{O}$ & 2.41594 & 0.46191 & -0.35104 \\
$\mathrm{H}$ & -0.78968 & 3.33076 & -0.72734 \\
$\mathrm{H}$ & 0.61265 & -0.20804 & 0.35563 \\
$\mathrm{H}$ & 0.79648 & 1.76962 & -1.97809 \\
$\mathrm{H}$ & -1.57849 & 0.23036 & -0.58129 \\
$\mathrm{C}$ & 2.89425 & -0.80143 & -0.05924 \\
$\mathrm{H}$ & -3.13167 & 1.99268 & 0.72855 \\
$\mathrm{H}$ & -2.70012 & 3.70714 & 0.76905 \\
$\mathrm{H}$ & -2.63170 & 1.94703 & -2.19478 \\
$\mathrm{H}$ & 0.22026 & -0.02723 & -3.18155 \\
$\mathrm{H}$ & -3.58933 & 3.91226 & -1.24272 \\
$\mathrm{O}$ & 2.17824 & -1.69091 & 0.33720 \\
$\mathrm{C}$ & 4.39884 & -0.88396 & -0.29892 \\
$\mathrm{C}$ & 4.69513 & -0.54018 & -1.77439 \\
$\mathrm{C}$ & 4.87546 & -2.30865 & 0.01507 \\
$\mathrm{C}$ & 5.10386 & 0.12714 & 0.63207 \\
$\mathrm{H}$ & 1.30614 & 2.78373 & 0.38325 \\
$\mathrm{O}$ & 1.35904 & 1.54239 & 2.02696 \\
$\mathrm{C}$ & 1.58342 & 2.65698 & 2.90787 \\
$\mathrm{H}$ & 2.06987 & 2.24878 & 3.79476 \\
$\mathrm{H}$ & 0.63684 & 3.13176 & 3.18846 \\
$\mathrm{H}$ & 2.24459 & 3.39324 & 2.43149 \\
$\mathrm{H}$ & -3.73749 & -3.90169 & 1.32685 \\
$\mathrm{C}$ & -3.25200 & -3.00987 & 0.92051 \\
$\mathrm{H}$ & -1.43190 & -4.09716 & 0.41983 \\
$\mathrm{H}$ & -3.38173 & -1.95555 & 2.82520 \\
$\mathrm{H}$ & -4.80136 & -2.73571 & -0.58819 \\
$\mathrm{H}$ & -1.82642 & -2.73948 & 2.53638 \\
$\mathrm{H}$ & -2.56059 & -3.92221 & -0.92604 \\
$\mathrm{H}$ & -5.03423 & -1.76516 & 0.86724 \\
& & & \\
\hline
\end{tabular}




$\begin{array}{lrrr}\mathrm{C} & -2.13712 & -3.41023 & -0.05635 \\ \mathrm{C} & -2.63568 & -2.18053 & 2.05739 \\ \mathrm{C} & -4.28020 & -2.14719 & 0.17206 \\ \mathrm{C} & -1.37900 & -2.12723 & -0.50492 \\ \mathrm{C} & -2.08423 & -0.85121 & 1.46516 \\ \mathrm{C} & -3.53211 & -0.96398 & -0.50869 \\ \mathrm{~N} & -2.13216 & -0.93797 & -0.01692 \\ \mathrm{H} & -0.37188 & -2.07872 & -0.08852 \\ \mathrm{H} & -2.68505 & 0.00959 & 1.76401 \\ \mathrm{H} & -3.48935 & -1.07021 & -1.59487 \\ \mathrm{H} & -1.05248 & -0.66146 & 1.76306 \\ \mathrm{H} & -1.29712 & -2.04423 & -1.58815 \\ \mathrm{H} & -3.99418 & -0.00168 & -0.27654 \\ \mathrm{H} & 6.18697 & 0.04170 & 0.49757 \\ \mathrm{H} & 4.87447 & -0.07923 & 1.68294 \\ \mathrm{H} & 4.80711 & 1.15429 & 0.40520 \\ \mathrm{H} & 4.38102 & -3.04305 & -0.62709 \\ \mathrm{H} & 4.66991 & -2.57636 & 1.05517 \\ \mathrm{H} & 5.95504 & -2.37309 & -0.15279 \\ \mathrm{H} & 4.16698 & -1.22059 & -2.45085 \\ \mathrm{H} & 5.76939 & -0.64589 & -1.95681 \\ \mathrm{H} & 4.40374 & 0.48561 & -2.01362\end{array}$

\section{[3-O-Piv- $\alpha$-glu]}

Energy (Hartree/particle): -996.888776867

$\begin{array}{lc}\text { Zero-point correction }= & 0.339275 \text { (Hartree/Particle) } \\ \text { Thermal correction to Energy= } & 0.360993 \\ \text { Thermal correction to Enthalpy= } & 0.361937 \\ \text { Thermal correction to Gibbs Free Energy= } & 0.288163 \\ \text { Sum of electronic and zero-point Energies }= & -996.549502 \\ \text { Sum of electronic and thermal Energies }= & -996.527784 \\ \text { Sum of electronic and thermal Enthalpies }= & -996.526840 \\ \text { Sum of electronic and thermal Free Energies }= & -996.600614\end{array}$

\section{Number of imaginary frequencies: 0}

\section{Geometry:}

$\begin{array}{lrrr}\mathrm{C} & -2.21718 & -1.44769 & -0.55237 \\ \mathrm{C} & -0.71465 & -1.36870 & -0.84328 \\ \mathrm{C} & -0.08723 & -0.25504 & -0.00881 \\ \mathrm{O} & 1.29952 & -0.14626 & -0.41561 \\ \mathrm{C} & -0.78865 & 1.07004 & -0.27890\end{array}$




$\begin{array}{lrrr}\mathrm{C} & -2.30703 & 0.89923 & -0.07187 \\ \mathrm{C} & -3.10838 & 2.12287 & -0.52143 \\ \mathrm{O} & -2.76379 & 3.31156 & 0.20889 \\ \mathrm{O} & -2.82182 & -0.18838 & -0.85529 \\ \mathrm{O} & -0.24218 & 2.05183 & 0.59153 \\ \mathrm{O} & -0.12548 & -2.63687 & -0.60413 \\ \mathrm{O} & -2.40624 & -1.83186 & 0.77883 \\ \mathrm{H} & -2.48494 & 0.71242 & 0.99931 \\ \mathrm{H} & -2.70557 & -2.15606 & -1.23728 \\ \mathrm{H} & -0.62395 & -1.09733 & -1.90815 \\ \mathrm{H} & -0.12422 & -0.49936 & 1.05478 \\ \mathrm{H} & -0.61574 & 1.34521 & -1.33496 \\ \mathrm{C} & -3.74878 & -2.20645 & 1.08231 \\ \mathrm{H} & 0.82769 & -2.53139 & -0.73242 \\ \mathrm{H} & -2.88607 & 2.34258 & -1.57059 \\ \mathrm{H} & -4.18136 & 1.90216 & -0.43879 \\ \mathrm{H} & -0.79540 & 2.84479 & 0.48772 \\ \mathrm{C} & 2.26153 & -0.13942 & 0.56100 \\ \mathrm{H} & -3.08037 & 3.20433 & 1.11669 \\ \mathrm{H} & -3.75352 & -2.52743 & 2.12639 \\ \mathrm{H} & -4.07466 & -3.04038 & 0.44266 \\ \mathrm{H} & -4.44180 & -1.36453 & 0.95198 \\ \mathrm{C} & 3.64208 & 0.12942 & -0.05260 \\ \mathrm{C} & 3.94812 & -0.94459 & -1.11658 \\ \mathrm{C} & 4.69836 & 0.08019 & 1.05846 \\ \mathrm{C} & 3.62795 & 1.52758 & -0.70541 \\ \mathrm{O} & 2.03466 & -0.32750 & 1.73090 \\ \mathrm{H} & 2.90279 & 1.57679 & -1.52157 \\ \mathrm{H} & 4.62303 & 1.75106 & -1.10664 \\ \mathrm{H} & 3.37138 & 2.29857 & 0.02850 \\ \mathrm{H} & 5.68757 & 0.27587 & 0.63011 \\ \mathrm{H} & 4.71641 & -0.89952 & 1.54479 \\ \mathrm{H} & 4.49584 & 0.83060 & 1.82751 \\ \mathrm{H} & 3.22644 & -0.91046 & -1.93712 \\ \mathrm{H} & 3.93410 & -1.94883 & -0.67678 \\ \mathrm{H} & 4.94827 & -0.77379 & -1.53039\end{array}$

\section{[3-O-Piv- $\alpha$-glu(H1)•quinuclidine $]^{\bullet+}($ transition state for HAT)}

Energy (Hartree/particle): -1325.86528099

Zero-point correction $=$

Thermal correction to Energy=

Thermal correction to Enthalpy=
0.527851 (Hartree/Particle)

0.557649

0.558593 
Thermal correction to Gibbs Free Energy $=\quad 0.464959$

Sum of electronic and zero-point Energies $=\quad-1325.337430$

Sum of electronic and thermal Energies $=\quad-1325.307632$

Sum of electronic and thermal Enthalpies $=\quad-1325.306688$

Sum of electronic and thermal Free Energies $=\quad-1325.400322$

Number of imaginary frequencies: $1,-837.4736$

\begin{tabular}{lrrr}
\multicolumn{4}{l}{ Geometry: } \\
$\mathrm{C}$ & -2.21718 & -1.44769 & -0.55237 \\
$\mathrm{C}$ & -0.71465 & -1.36870 & -0.84328 \\
$\mathrm{C}$ & -0.08723 & -0.25504 & -0.00881 \\
$\mathrm{O}$ & 1.29952 & -0.14626 & -0.41561 \\
$\mathrm{C}$ & -0.78865 & 1.07004 & -0.27890 \\
$\mathrm{C}$ & -2.30703 & 0.89923 & -0.07187 \\
$\mathrm{C}$ & -3.10838 & 2.12287 & -0.52143 \\
$\mathrm{O}$ & -2.76379 & 3.31156 & 0.20889 \\
$\mathrm{O}$ & -2.82182 & -0.18838 & -0.85529 \\
$\mathrm{O}$ & -0.24218 & 2.05183 & 0.59153 \\
$\mathrm{O}$ & -0.12548 & -2.63687 & -0.60413 \\
$\mathrm{O}$ & -2.40624 & -1.83186 & 0.77883 \\
$\mathrm{H}$ & -2.48494 & 0.71242 & 0.99931 \\
$\mathrm{H}$ & -2.70557 & -2.15606 & -1.23728 \\
$\mathrm{H}$ & -0.62395 & -1.09733 & -1.90815 \\
$\mathrm{H}$ & -0.12422 & -0.49936 & 1.05478 \\
$\mathrm{H}$ & -0.61574 & 1.34521 & -1.33496 \\
$\mathrm{C}$ & -3.74878 & -2.20645 & 1.08231 \\
$\mathrm{H}$ & 0.82769 & -2.53139 & -0.73242 \\
$\mathrm{H}$ & -2.88607 & 2.34258 & -1.57059 \\
$\mathrm{H}$ & -4.18136 & 1.90216 & -0.43879 \\
$\mathrm{H}$ & -0.79540 & 2.84479 & 0.48772 \\
$\mathrm{C}$ & 2.26153 & -0.13942 & 0.56100 \\
$\mathrm{H}$ & -3.08037 & 3.20433 & 1.11669 \\
$\mathrm{H}$ & -3.75352 & -2.52743 & 2.12639 \\
$\mathrm{H}$ & -4.07466 & -3.04038 & 0.44266 \\
$\mathrm{H}$ & -4.44180 & -1.36453 & 0.95198 \\
$\mathrm{C}$ & 3.64208 & 0.12942 & -0.05260 \\
$\mathrm{C}$ & 3.94812 & -0.94459 & -1.11658 \\
$\mathrm{C}$ & 4.69836 & 0.08019 & 1.05846 \\
$\mathrm{C}$ & 3.62795 & 1.52758 & -0.70541 \\
$\mathrm{O}$ & 2.03466 & -0.32750 & 1.73090 \\
$\mathrm{H}$ & 2.90279 & 1.57679 & -1.52157 \\
$\mathrm{H}$ & 4.62303 & 1.75106 & -1.10664 \\
$\mathrm{H}$ & 3.37138 & 2.29857 & 0.02850 \\
$\mathrm{H}$ & 5.68757 & 0.27587 & 0.63011 \\
$\mathrm{H}$ & 4.71641 & -0.89952 & 1.54479 \\
& & & \\
& & &
\end{tabular}




$\begin{array}{llll}\mathrm{H} & 4.49584 & 0.83060 & 1.82751 \\ \mathrm{H} & 3.22644 & -0.91046 & -1.93712 \\ \mathrm{H} & 3.93410 & -1.94883 & -0.67678 \\ \mathrm{H} & 4.94827 & -0.77379 & -1.53039\end{array}$

\section{[3-O-Piv- $\alpha$-glu(H2)•quinuclidine ${ }^{++}($transition state for HAT)}

Energy (Hartree/particle): -1325.86047667

$\begin{array}{lc}\text { Zero-point correction }= & 0.527438 \text { (Hartree/Particle) } \\ \text { Thermal correction to Energy= } & 0.557226 \\ \text { Thermal correction to Enthalpy= } & 0.558170 \\ \text { Thermal correction to Gibbs Free Energy= } & 0.465213 \\ \text { Sum of electronic and zero-point Energies }= & -1325.333039 \\ \text { Sum of electronic and thermal Energies }= & -1325.303251 \\ \text { Sum of electronic and thermal Enthalpies }= & -1325.302307 \\ \text { Sum of electronic and thermal Free Energies }= & -1325.395264\end{array}$

Number of imaginary frequencies: $1,-1072.5672$

\begin{tabular}{lrrr}
\multicolumn{4}{l}{ Geometry: } \\
$\mathrm{C}$ & -0.82400 & 0.82851 & 0.52937 \\
$\mathrm{C}$ & 0.19350 & -0.20299 & 0.00495 \\
$\mathrm{C}$ & 1.59258 & 0.40970 & 0.20094 \\
$\mathrm{O}$ & 2.60475 & -0.41938 & -0.39899 \\
$\mathrm{C}$ & 1.68324 & 1.77250 & -0.48459 \\
$\mathrm{C}$ & 0.53031 & 2.69997 & -0.04943 \\
$\mathrm{C}$ & 0.39221 & 3.93632 & -0.94344 \\
$\mathrm{O}$ & 1.60399 & 4.69252 & -0.99291 \\
$\mathrm{O}$ & -0.77049 & 2.02623 & -0.14565 \\
$\mathrm{O}$ & 2.92609 & 2.34333 & -0.12119 \\
$\mathrm{O}$ & 0.00461 & -1.45492 & 0.60557 \\
$\mathrm{O}$ & -0.81519 & 0.88822 & 1.90181 \\
$\mathrm{H}$ & 0.70865 & 2.99552 & 0.99377 \\
$\mathrm{H}$ & -1.94308 & 0.29381 & 0.19587 \\
$\mathrm{H}$ & 0.01335 & -0.28691 & -1.07711 \\
$\mathrm{H}$ & 1.80265 & 0.51329 & 1.27098 \\
$\mathrm{H}$ & 1.61856 & 1.61382 & -1.57472 \\
$\mathrm{C}$ & -1.56523 & 1.94931 & 2.52359 \\
$\mathrm{H}$ & 0.80355 & -1.66171 & 1.14027 \\
$\mathrm{H}$ & 0.18582 & 3.61071 & -1.96860 \\
$\mathrm{H}$ & -0.45393 & 4.54568 & -0.60159 \\
$\mathrm{H}$ & 2.95783 & 3.22395 & -0.53459 \\
& & &
\end{tabular}




$\begin{array}{lrrr}\mathrm{C} & 3.12639 & -1.42542 & 0.36260 \\ \mathrm{H} & 1.62107 & 5.31171 & -0.25070 \\ \mathrm{H} & -1.11644 & 2.92579 & 2.32201 \\ \mathrm{H} & -1.54051 & 1.73760 & 3.59253 \\ \mathrm{H} & -2.60005 & 1.94959 & 2.16278 \\ \mathrm{C} & 4.41966 & -1.97461 & -0.22409 \\ \mathrm{C} & 4.22958 & -2.29076 & -1.72218 \\ \mathrm{C} & 4.82083 & -3.24356 & 0.53966 \\ \mathrm{C} & 5.50173 & -0.88177 & -0.04930 \\ \mathrm{O} & 2.59780 & -1.79280 & 1.39667 \\ \mathrm{H} & -6.23711 & 0.01082 & 0.07346 \\ \mathrm{H} & -4.27425 & 1.26638 & 0.33608 \\ \mathrm{H} & -3.86518 & 1.07445 & -1.37567 \\ \mathrm{C} & -5.50765 & -0.25102 & -0.69896 \\ \mathrm{H} & -5.94163 & 0.01906 & -1.66590 \\ \mathrm{C} & -4.18585 & 0.54202 & -0.47706 \\ \mathrm{H} & -5.46495 & -1.96722 & 1.50486 \\ \mathrm{C} & -5.19353 & -1.75510 & -0.64607 \\ \mathrm{~N} & -3.11182 & -0.41564 & -0.12167 \\ \mathrm{H} & -6.09464 & -2.33196 & -0.87226 \\ \mathrm{H} & -3.69360 & -0.48475 & 1.88393 \\ \mathrm{C} & -4.67915 & -2.11187 & 0.75784 \\ \mathrm{C} & -3.46266 & -1.19966 & 1.09061 \\ \mathrm{H} & -2.41128 & -0.69541 & -2.07500 \\ \mathrm{C} & -2.79839 & -1.31470 & -1.26199 \\ \mathrm{C} & -4.09541 & -2.07110 & -1.67346 \\ \mathrm{H} & -4.41223 & -1.76194 & -2.67413 \\ \mathrm{H} & -4.37969 & -3.16348 & 0.79503 \\ \mathrm{H} & -2.57510 & -1.76355 & 1.38144 \\ \mathrm{H} & -2.00942 & -1.99111 & -0.92905 \\ \mathrm{H} & -3.89722 & -3.14609 & -1.70811 \\ \mathrm{H} & 5.15890 & -2.71576 & -2.11407 \\ \mathrm{H} & 3.99266 & -1.39280 & -2.29750 \\ \mathrm{H} & 3.43203 & -3.02647 & -1.87332 \\ \mathrm{H} & 6.44908 & -1.25527 & -0.45104 \\ \mathrm{H} & 5.65150 & -0.64322 & 1.00884 \\ 5.23236 & 0.03497 & -0.57999 \\ \mathrm{H} & 4.76205 & -3.62534 & 0.13241 \\ \mathrm{H} & -96079 & -4.02453 & 0.44005 \\ -3.04050 & 1.60436\end{array}$

[3-O-Piv- $\alpha$-glu(H3)•quinuclidine $]^{\bullet+}($ transition state for HAT) 
Energy (Hartree/particle): -1325.86366853

$\begin{array}{lc}\text { Zero-point correction }= & 0.528024 \\ \text { Thermal correction to Energy= }= & 0.557436 \\ \text { Thermal correction to Enthalpy= }= & 0.558380 \\ \text { Thermal correction to Gibbs Free Energy }= & 0.467841 \\ \text { Sum of electronic and zero-point Energies }= & -1325.335645 \\ \text { Sum of electronic and thermal Energies }= & -1325.306233 \\ \text { Sum of electronic and thermal Enthalpies }= & -1325.305288 \\ \text { Sum of electronic and thermal Free Energies }= & -1325.395828\end{array}$

Number of imaginary frequencies: $1,-1482.0103$

\begin{tabular}{lrcc}
\multicolumn{4}{l}{ Geometry: } \\
$\mathrm{C}$ & -1.90631 & 1.41999 & -1.74823 \\
$\mathrm{C}$ & -0.37108 & 1.32232 & -1.66410 \\
$\mathrm{C}$ & 0.07753 & 0.96170 & -0.24029 \\
$\mathrm{O}$ & 1.44170 & 1.17460 & 0.07806 \\
$\mathrm{C}$ & -0.69537 & 1.66011 & 0.87476 \\
$\mathrm{C}$ & -2.19895 & 1.79712 & 0.57581 \\
$\mathrm{C}$ & -2.87417 & 2.80188 & 1.50470 \\
$\mathrm{O}$ & -2.71186 & 2.32013 & 2.84910 \\
$\mathrm{O}$ & -2.40909 & 2.29187 & -0.74718 \\
$\mathrm{O}$ & -0.45324 & 0.95483 & 2.08659 \\
$\mathrm{O}$ & 0.05566 & 0.47926 & -2.69776 \\
$\mathrm{O}$ & -2.44993 & 0.13039 & -1.66683 \\
$\mathrm{H}$ & -2.67736 & 0.81807 & 0.70153 \\
$\mathrm{H}$ & -2.17706 & 1.89589 & -2.69979 \\
$\mathrm{H}$ & 0.00023 & 2.35656 & -1.81333 \\
$\mathrm{H}$ & -0.13112 & -0.34081 & -0.09625 \\
$\mathrm{H}$ & -0.27499 & 2.68113 & 0.93446 \\
$\mathrm{C}$ & -3.81831 & 0.05684 & -2.09904 \\
$\mathrm{H}$ & 0.97616 & 0.21137 & -2.51200 \\
$\mathrm{H}$ & -2.40604 & 3.78825 & 1.37709 \\
$\mathrm{H}$ & -3.93594 & 2.87875 & 1.23742 \\
$\mathrm{H}$ & -1.03808 & 1.36672 & 2.75144 \\
$\mathrm{C}$ & 2.51139 & 0.59040 & -0.54939 \\
$\mathrm{H}$ & -3.04417 & 2.98704 & 3.46355 \\
$\mathrm{H}$ & -4.11677 & -0.98992 & -2.01041 \\
$\mathrm{H}$ & -3.90426 & 0.37238 & -3.14655 \\
$\mathrm{H}$ & -4.46671 & 0.68129 & -1.47351 \\
$\mathrm{C}$ & 3.82229 & 1.02917 & 0.08862 \\
$\mathrm{C}$ & 3.91791 & 2.57056 & 0.02644 \\
$\mathrm{C}$ & 4.98973 & 0.39450 & -0.67861 \\
$\mathrm{C}$ & 3.83412 & 0.56198 & 1.56292 \\
$\mathrm{O}$ & 2.38985 & -0.18779 & -1.47408
\end{tabular}




$\begin{array}{lrrr}\mathrm{H} & -2.12121 & -3.57360 & 2.03940 \\ \mathrm{H} & -1.55122 & -1.31192 & 1.75253 \\ \mathrm{H} & -2.32480 & -1.41447 & 0.15714 \\ \mathrm{C} & -1.79805 & -3.38721 & 1.01107 \\ \mathrm{H} & -2.58982 & -3.74478 & 0.34562 \\ \mathrm{C} & -1.57640 & -1.86108 & 0.81123 \\ \mathrm{H} & 0.36514 & -3.50415 & 2.61427 \\ \mathrm{C} & -0.48198 & -4.11726 & 0.70906 \\ \mathrm{~N} & -0.25420 & -1.65662 & 0.16117 \\ \mathrm{H} & -0.57710 & -5.18087 & 0.94596 \\ \mathrm{H} & 0.84970 & -1.30527 & 1.90478 \\ \mathrm{C} & 0.63608 & -3.48712 & 1.55421 \\ \mathrm{C} & 0.85520 & -2.02048 & 1.08146 \\ \mathrm{H} & -1.01070 & -2.11242 & -1.72870 \\ \mathrm{C} & -0.15996 & -2.41313 & -1.11745 \\ \mathrm{C} & -0.15067 & -3.93336 & -0.77930 \\ \mathrm{H} & -0.88521 & -4.44816 & -1.40524 \\ \mathrm{H} & 1.56980 & -4.04577 & 1.44285 \\ \mathrm{H} & 1.78300 & -1.91358 & 0.51838 \\ \mathrm{H} & 0.75373 & -2.09923 & -1.61915 \\ \mathrm{H} & 0.83137 & -4.36005 & -1.00535 \\ \mathrm{H} & 4.99734 & 0.70923 & -1.72579 \\ \mathrm{H} & 4.93865 & -0.69763 & -0.65360 \\ \mathrm{H} & 5.93185 & 0.70588 & -0.21818 \\ \mathrm{H} & 3.86475 & 2.92908 & -1.00696 \\ \mathrm{H} & 4.88204 & 2.87980 & 0.44126 \\ \mathrm{H} & 3.12459 & 3.04747 & 0.60728 \\ \mathrm{H} & 3.78328 & -0.53024 & 1.63145 \\ \mathrm{H} & 3.00412 & 0.99159 & 2.12902 \\ \mathrm{H} & 4.77343 & 0.88081 & 2.02476\end{array}$

\section{[3-O-Piv- $\alpha$-glu(H4)•quinuclidine $]^{\bullet+}($ transition state for HAT)}

Energy (Hartree/particle): -1325.86349319

$\begin{array}{lc}\text { Zero-point correction }= & 0.527476 \text { (Hartree/Particle) } \\ \text { Thermal correction to Energy= } & 0.557287 \\ \text { Thermal correction to Enthalpy= } & 0.558232 \\ \text { Thermal correction to Gibbs Free Energy= } & 0.465298 \\ \text { Sum of electronic and zero-point Energies }= & -1325.336018 \\ \text { Sum of electronic and thermal Energies }= & -1325.306206 \\ \text { Sum of electronic and thermal Enthalpies }= & -1325.305262 \\ \text { Sum of electronic and thermal Free Energies }= & -1325.398195\end{array}$


Number of imaginary frequencies: $1,-869.1794$

\begin{tabular}{|c|c|c|c|}
\hline \multicolumn{4}{|c|}{ Geometry: } \\
\hline $\mathrm{C}$ & -0.05674 & -2.79909 & -1.26436 \\
\hline $\mathrm{C}$ & 0.67090 & -1.45458 & -1.42936 \\
\hline $\mathrm{C}$ & 1.07553 & -0.91322 & -0.05582 \\
\hline $\mathrm{O}$ & 1.66895 & 0.38513 & -0.22404 \\
\hline $\mathrm{C}$ & -0.13281 & -0.84553 & 0.86694 \\
\hline $\mathrm{C}$ & -0.87588 & -2.19222 & 0.89938 \\
\hline $\mathrm{C}$ & -2.17219 & -2.18517 & 1.71258 \\
\hline $\mathrm{O}$ & -1.95388 & -1.65070 & 3.03374 \\
\hline $\mathrm{O}$ & -1.21893 & -2.59361 & -0.41965 \\
\hline $\mathrm{O}$ & 0.16403 & -0.28938 & 2.08542 \\
\hline $\mathrm{O}$ & 1.77738 & -1.64120 & -2.28187 \\
\hline $\mathrm{O}$ & 0.82081 & -3.72875 & -0.73802 \\
\hline $\mathrm{H}$ & -0.17721 & -2.91810 & 1.35042 \\
\hline $\mathrm{H}$ & -0.48217 & -3.12866 & -2.22122 \\
\hline $\mathrm{H}$ & -0.05835 & -0.76259 & -1.88390 \\
\hline $\mathrm{H}$ & 1.82129 & -1.57522 & 0.40362 \\
\hline $\mathrm{H}$ & -0.95029 & -0.01879 & 0.29376 \\
\hline $\mathrm{C}$ & 0.41053 & -5.09613 & -0.90272 \\
\hline $\mathrm{H}$ & 2.24387 & -0.79672 & -2.35829 \\
\hline $\mathrm{H}$ & -2.91611 & -1.54288 & 1.23328 \\
\hline $\mathrm{H}$ & -2.58359 & -3.19861 & 1.75239 \\
\hline $\mathrm{H}$ & -0.51503 & -0.61921 & 2.72406 \\
\hline $\mathrm{C}$ & 2.89099 & 0.58609 & 0.41078 \\
\hline $\mathrm{H}$ & -1.79934 & -2.37705 & 3.65247 \\
\hline $\mathrm{H}$ & 1.20457 & -5.70690 & -0.47091 \\
\hline $\mathrm{H}$ & 0.30124 & -5.33455 & -1.96849 \\
\hline $\mathrm{H}$ & -0.53517 & -5.29189 & -0.38260 \\
\hline $\mathrm{C}$ & 3.39092 & 2.01926 & 0.22740 \\
\hline $\mathrm{C}$ & 3.15472 & 2.52089 & -1.20887 \\
\hline $\mathrm{C}$ & 4.89074 & 2.06192 & 0.55863 \\
\hline $\mathrm{C}$ & 2.61299 & 2.89846 & 1.23410 \\
\hline $\mathrm{O}$ & 3.43654 & -0.28059 & 1.04195 \\
\hline $\mathrm{H}$ & -4.28475 & 2.72600 & 1.15468 \\
\hline $\mathrm{H}$ & -3.07594 & 0.75511 & 1.50378 \\
\hline $\mathrm{H}$ & -1.65244 & 1.76867 & 1.78591 \\
\hline $\mathrm{C}$ & -3.28835 & 2.80520 & 0.71066 \\
\hline $\mathrm{H}$ & -2.81725 & 3.70424 & 1.11935 \\
\hline $\mathrm{C}$ & -2.45390 & 1.54527 & 1.07801 \\
\hline $\mathrm{H}$ & -4.85613 & 1.30998 & -0.90252 \\
\hline $\mathrm{C}$ & -3.37731 & 2.90051 & -0.82069 \\
\hline $\mathrm{N}$ & -1.82698 & 1.00508 & -0.15480 \\
\hline $\mathrm{H}$ & -4.04726 & 3.71546 & -1.10805 \\
\hline $\mathrm{H}$ & -3.29016 & -0.42805 & -0.62831 \\
\hline
\end{tabular}




$\begin{array}{lrll}\mathrm{C} & -3.90165 & 1.56524 & -1.37327 \\ \mathrm{C} & -2.84741 & 0.45827 & -1.08442 \\ \mathrm{H} & -0.31790 & 2.44180 & -0.08600 \\ \mathrm{C} & -1.01591 & 2.05173 & -0.82722 \\ \mathrm{C} & -1.96858 & 3.14856 & -1.38125 \\ \mathrm{H} & -1.60085 & 4.13556 & -1.08612 \\ \mathrm{H} & -4.07529 & 1.63229 & -2.45105 \\ \mathrm{H} & -2.32372 & 0.14150 & -1.98880 \\ \mathrm{H} & -0.43317 & 1.57223 & -1.61475 \\ \mathrm{H} & -1.98554 & 3.11795 & -2.47507 \\ \mathrm{H} & 3.66158 & 1.88166 & -1.94023 \\ \mathrm{H} & 3.56721 & 3.52981 & -1.30907 \\ \mathrm{H} & 2.09185 & 2.56098 & -1.46006 \\ \mathrm{H} & 5.46432 & 1.43211 & -0.12805 \\ \mathrm{H} & 5.08214 & 1.71350 & 1.57591 \\ \mathrm{H} & 5.25233 & 3.09079 & 0.46635 \\ \mathrm{H} & 1.53833 & 2.89091 & 1.02688 \\ \mathrm{H} & 2.96962 & 3.93091 & 1.16073 \\ \mathrm{H} & 2.76940 & 2.55216 & 2.26019\end{array}$

[3-O-Piv- $\alpha$-glu(H5)•quinuclidine $]^{\bullet+}($ transition state for HAT)

Energy (Hartree/particle): -1325.86556838

Zero-point correction $=$

Thermal correction to Energy=

Thermal correction to Enthalpy=

Thermal correction to Gibbs Free Energy=

Sum of electronic and zero-point Energies=

Sum of electronic and thermal Energies=

Sum of electronic and thermal Enthalpies=

Sum of electronic and thermal Free Energies=
0.527904 (Hartree/Particle)

0.557785

0.558730

0.466190

$-1325.337665$

$-1325.307783$

$-1325.306839$

$-1325.399378$

Number of imaginary frequencies: 1, -1191.1980

\section{Geometry:}

$\begin{array}{lrrr}\mathrm{C} & -0.23910 & 2.71709 & -0.21958 \\ \mathrm{C} & 1.21236 & 2.24443 & -0.06916 \\ \mathrm{C} & 1.21894 & 0.74227 & 0.19171 \\ \mathrm{O} & 2.57995 & 0.30399 & 0.27729 \\ \mathrm{C} & 0.49449 & 0.45194 & 1.49843 \\ \mathrm{C} & -0.89915 & 1.12231 & 1.49980\end{array}$




\begin{tabular}{|c|c|c|c|}
\hline $\mathrm{C}$ & -1.60192 & 1.17781 & 2.85159 \\
\hline $\mathrm{O}$ & -1.58615 & -0.12240 & 3.44834 \\
\hline $\mathrm{O}$ & -0.98916 & 2.39535 & 0.96993 \\
\hline $\mathrm{O}$ & 0.40250 & -0.94603 & 1.68125 \\
\hline $\mathrm{O}$ & 1.88478 & 2.59559 & -1.26167 \\
\hline $\mathrm{O}$ & -0.88138 & 2.12937 & -1.31425 \\
\hline $\mathrm{H}$ & -1.59038 & 0.28643 & 0.76793 \\
\hline $\mathrm{H}$ & -0.28401 & 3.81028 & -0.27881 \\
\hline $\mathrm{H}$ & 1.64795 & 2.76936 & 0.79796 \\
\hline $\mathrm{H}$ & 0.73940 & 0.22238 & -0.63771 \\
\hline $\mathrm{H}$ & 1.06945 & 0.91341 & 2.32364 \\
\hline $\mathrm{C}$ & -1.06488 & 2.99405 & -2.45254 \\
\hline $\mathrm{H}$ & 2.79533 & 2.27479 & -1.19105 \\
\hline $\mathrm{H}$ & -1.06357 & 1.90650 & 3.47731 \\
\hline $\mathrm{H}$ & -2.62919 & 1.54459 & 2.71394 \\
\hline $\mathrm{H}$ & -0.02901 & -1.08623 & 2.54054 \\
\hline $\mathrm{C}$ & 2.90410 & -0.85096 & -0.41822 \\
\hline $\mathrm{H}$ & -1.81261 & -0.03574 & 4.38352 \\
\hline $\mathrm{H}$ & -1.64213 & 2.41833 & -3.17900 \\
\hline $\mathrm{H}$ & -0.09991 & 3.27261 & -2.88487 \\
\hline $\mathrm{H}$ & -1.62750 & 3.89228 & -2.16659 \\
\hline $\mathrm{C}$ & 4.37241 & -1.21519 & -0.20998 \\
\hline $\mathrm{C}$ & 4.69917 & -2.45761 & -1.04910 \\
\hline $\mathrm{C}$ & 4.59774 & -1.51391 & 1.28863 \\
\hline $\mathrm{C}$ & 5.25944 & -0.03120 & -0.65177 \\
\hline $\mathrm{O}$ & 2.10059 & -1.45038 & -1.08912 \\
\hline $\mathrm{H}$ & -3.67467 & -3.58235 & 0.18231 \\
\hline $\mathrm{H}$ & -1.96333 & -2.28939 & 1.13685 \\
\hline $\mathrm{H}$ & -3.24147 & -1.27236 & 1.81278 \\
\hline $\mathrm{C}$ & -3.90953 & -2.51686 & 0.10546 \\
\hline $\mathrm{H}$ & -4.90171 & -2.36627 & 0.54255 \\
\hline $\mathrm{C}$ & -2.84482 & -1.69691 & 0.88975 \\
\hline $\mathrm{H}$ & -2.05607 & -3.14087 & -1.75771 \\
\hline $\mathrm{C}$ & -3.90032 & -2.06111 & -1.36212 \\
\hline $\mathrm{N}$ & -2.38345 & -0.57980 & 0.02518 \\
\hline $\mathrm{H}$ & -4.55648 & -2.70047 & -1.95949 \\
\hline $\mathrm{H}$ & -0.67933 & -1.54825 & -0.71898 \\
\hline $\mathrm{C}$ & -2.46088 & -2.13339 & -1.89285 \\
\hline $\mathrm{C}$ & -1.58938 & -1.10112 & -1.11982 \\
\hline $\mathrm{H}$ & -4.10188 & 0.52685 & 0.44816 \\
\hline $\mathrm{C}$ & -3.52969 & 0.24257 & -0.43883 \\
\hline $\mathrm{C}$ & -4.37937 & -0.60249 & -1.43007 \\
\hline $\mathrm{H}$ & -5.43726 & -0.52532 & -1.16268 \\
\hline $\mathrm{H}$ & -2.42897 & -1.90740 & -2.96258 \\
\hline $\mathrm{H}$ & -1.31839 & -0.24414 & -1.73637 \\
\hline $\mathrm{H}$ & -3.12237 & 1.14449 & -0.89641 \\
\hline
\end{tabular}




$\begin{array}{lrrr}\mathrm{H} & -4.26789 & -0.21512 & -2.44763 \\ \mathrm{H} & 4.53738 & -2.27162 & -2.11466 \\ \mathrm{H} & 4.07701 & -3.30779 & -0.75672 \\ \mathrm{H} & 5.74908 & -2.72836 & -0.90012 \\ \mathrm{H} & 3.95079 & -2.32983 & 1.62747 \\ \mathrm{H} & 4.40214 & -0.63359 & 1.90636 \\ \mathrm{H} & 5.63815 & -1.81903 & 1.44006 \\ \mathrm{H} & 5.08091 & 0.22541 & -1.70232 \\ \mathrm{H} & 6.31234 & -0.31341 & -0.55200 \\ \mathrm{H} & 5.08574 & 0.85420 & -0.03396\end{array}$

\section{[2-O-Piv- $\beta$-xylo]}

Energy (Hartree/particle): -882.370128376

$\begin{array}{lc}\text { Zero-point correction }= & 0.306885 \text { (Hartree/Particle) } \\ \text { Thermal correction to Energy }= & 0.326225 \\ \text { Thermal correction to Enthalpy= } & 0.327169 \\ \text { Thermal correction to Gibbs Free Energy= } & 0.258062 \\ \text { Sum of electronic and zero-point Energies }= & -882.063243 \\ \text { Sum of electronic and thermal Energies }= & -882.043903 \\ \text { Sum of electronic and thermal Enthalpies }= & -882.042959 \\ \text { Sum of electronic and thermal Free Energies }= & -882.112066\end{array}$

Number of imaginary frequencies: 0

\begin{tabular}{lrrr}
\multicolumn{4}{l}{ Geometry: } \\
$\mathrm{O}$ & -4.20641 & -1.73565 & 0.11348 \\
$\mathrm{C}$ & -3.61725 & -0.65629 & -0.64518 \\
$\mathrm{C}$ & -2.11595 & -0.92291 & -0.70458 \\
$\mathrm{O}$ & -1.48093 & 0.09884 & -1.49963 \\
$\mathrm{C}$ & -1.40806 & -0.91498 & 0.68709 \\
$\mathrm{H}$ & -0.91955 & -1.88333 & 0.86066 \\
$\mathrm{C}$ & -0.33849 & 0.17215 & 0.53900 \\
$\mathrm{C}$ & -0.82178 & 1.00868 & -0.66052 \\
$\mathrm{H}$ & -4.01491 & -0.63413 & -1.66833 \\
$\mathrm{H}$ & -3.79866 & 0.31280 & -0.16652 \\
$\mathrm{H}$ & -1.94083 & -1.87597 & -1.21670 \\
$\mathrm{O}$ & 0.90899 & -0.48191 & 0.20709 \\
$\mathrm{O}$ & -2.24665 & -0.57442 & 1.78232 \\
$\mathrm{H}$ & -5.15867 & -1.58340 & 0.16071 \\
$\mathrm{H}$ & -3.04877 & -1.11650 & 1.69022 \\
$\mathrm{H}$ & 0.00756 & 1.45335 & -1.22930 \\
$\mathrm{O}$ & -1.73622 & 2.01583 & -0.26266 \\
$\mathrm{H}$ & -0.22169 & 0.75589 & 1.45177
\end{tabular}




$\begin{array}{lrrr}\mathrm{C} & -1.09929 & 3.19402 & 0.22698 \\ \mathrm{H} & -1.89617 & 3.90873 & 0.44556 \\ \mathrm{H} & -0.42255 & 3.61933 & -0.53036 \\ \mathrm{H} & -0.52001 & 3.00275 & 1.14017 \\ \mathrm{C} & 2.03981 & 0.26519 & 0.34071 \\ \mathrm{C} & 3.27610 & -0.52097 & -0.11248 \\ \mathrm{C} & 3.34838 & -1.86502 & 0.63902 \\ \mathrm{C} & 4.53130 & 0.31173 & 0.17747 \\ \mathrm{C} & 3.15057 & -0.77432 & -1.63067 \\ \mathrm{O} & 2.03573 & 1.40532 & 0.75012 \\ \mathrm{H} & 3.08307 & 0.17044 & -2.18156 \\ \mathrm{H} & 2.26591 & -1.37376 & -1.86124 \\ \mathrm{H} & 4.03804 & -1.31085 & -1.98456 \\ \mathrm{H} & 4.49851 & 1.27210 & -0.34419 \\ \mathrm{H} & 5.41821 & -0.23775 & -0.15643 \\ \mathrm{H} & 4.63165 & 0.51590 & 1.24763 \\ \mathrm{H} & 4.25141 & -2.40442 & 0.33187 \\ \mathrm{H} & 2.47977 & -2.49138 & 0.42172 \\ \mathrm{H} & 3.39964 & -1.70749 & 1.72206\end{array}$

$[2-O-P i v-\beta-x y l o(H 2) \bullet q u i n u c l i d i n e]^{++}($transition state for HAT)

Energy (Hartree/particle): -1211.34285612

$\begin{array}{lc}\text { Zero-point correction }= & 0.495186 \text { (Hartree/Particle) } \\ \text { Thermal correction to Energy= } & 0.522616 \\ \text { Thermal correction to Enthalpy= } & 0.523560 \\ \text { Thermal correction to Gibbs Free Energy= } & 0.435686 \\ \text { Sum of electronic and zero-point Energies }= & -1210.847670 \\ \text { Sum of electronic and thermal Energies }= & -1210.820240 \\ \text { Sum of electronic and thermal Enthalpies }= & -1210.819296 \\ \text { Sum of electronic and thermal Free Energies }= & -1210.907170\end{array}$

Number of imaginary frequencies: $1,-1373.6248$

\section{Geometry:}

$\begin{array}{lrrr}\mathrm{O} & -2.70112 & 3.52939 & -1.58035 \\ \mathrm{C} & -2.14395 & 3.32429 & -0.26978 \\ \mathrm{C} & -0.65311 & 3.07641 & -0.49188 \\ \mathrm{O} & 0.06441 & 2.98750 & 0.75707 \\ \mathrm{C} & -0.31772 & 1.76469 & -1.25850 \\ \mathrm{H} & 0.46049 & 1.97149 & -2.00492 \\ \mathrm{C} & 0.31441 & 0.87285 & -0.17547 \\ \mathrm{C} & 0.18096 & 1.63358 & 1.15480 \\ \mathrm{H} & -2.26231 & 4.21581 & 0.35895 \\ \mathrm{H} & -2.60986 & 2.46693 & 0.23267\end{array}$




\begin{tabular}{|c|c|c|c|}
\hline $\mathrm{H}$ & -0.23717 & 3.93919 & -1.02019 \\
\hline $\mathrm{O}$ & 1.59458 & 0.50025 & -0.57037 \\
\hline $\mathrm{O}$ & -1.42324 & 1.12271 & -1.87628 \\
\hline $\mathrm{H}$ & -3.62184 & 3.80958 & -1.49719 \\
\hline $\mathrm{H}$ & -2.02551 & 1.82766 & -2.18440 \\
\hline $\mathrm{H}$ & 1.06408 & 1.57398 & 1.79805 \\
\hline $\mathrm{O}$ & -0.95646 & 1.14119 & 1.81859 \\
\hline $\mathrm{H}$ & -0.41061 & -0.21749 & -0.04988 \\
\hline $\mathrm{C}$ & -1.13815 & 1.70989 & 3.12754 \\
\hline $\mathrm{H}$ & -2.02496 & 1.23453 & 3.55071 \\
\hline $\mathrm{H}$ & -1.29213 & 2.79255 & 3.06727 \\
\hline $\mathrm{H}$ & -0.26704 & 1.49663 & 3.76122 \\
\hline $\mathrm{C}$ & 2.42060 & -0.23001 & 0.29741 \\
\hline $\mathrm{C}$ & 3.81834 & -0.37337 & -0.28269 \\
\hline $\mathrm{C}$ & 3.72070 & -1.15816 & -1.61194 \\
\hline $\mathrm{C}$ & 4.69133 & -1.13960 & 0.72019 \\
\hline $\mathrm{C}$ & 4.40667 & 1.03187 & -0.54042 \\
\hline $\mathrm{O}$ & 1.99775 & -0.67213 & 1.33395 \\
\hline $\mathrm{H}$ & -1.88746 & -3.68140 & -2.23926 \\
\hline $\mathrm{H}$ & -3.81683 & -2.37278 & -1.18508 \\
\hline $\mathrm{H}$ & -2.76679 & -0.31471 & -0.68678 \\
\hline $\mathrm{H}$ & -1.16237 & -1.44322 & -2.11547 \\
\hline $\mathrm{C}$ & -3.34098 & -2.40003 & -0.19972 \\
\hline $\mathrm{C}$ & -1.37863 & -3.49255 & -1.28966 \\
\hline $\mathrm{C}$ & -2.55176 & -1.08401 & 0.05268 \\
\hline $\mathrm{C}$ & -0.76204 & -2.06465 & -1.31360 \\
\hline $\mathrm{C}$ & -2.36320 & -3.58100 & -0.11243 \\
\hline $\mathrm{H}$ & -0.59117 & -4.24491 & -1.18198 \\
\hline $\mathrm{H}$ & -4.13435 & -2.49410 & 0.54755 \\
\hline $\mathrm{H}$ & -2.90751 & -4.52899 & -0.14758 \\
\hline $\mathrm{N}$ & -1.09795 & -1.38944 & -0.03322 \\
\hline $\mathrm{H}$ & -2.72593 & -0.67602 & 1.04862 \\
\hline $\mathrm{H}$ & 0.32662 & -2.08905 & -1.40282 \\
\hline $\mathrm{C}$ & -1.57767 & -3.46592 & 1.20280 \\
\hline $\mathrm{C}$ & -0.66644 & -2.20623 & 1.13127 \\
\hline $\mathrm{H}$ & -0.95371 & -4.34936 & 1.36647 \\
\hline $\mathrm{H}$ & -2.26734 & -3.38880 & 2.04907 \\
\hline $\mathrm{H}$ & -0.73650 & -1.57872 & 2.02002 \\
\hline $\mathrm{H}$ & 0.38042 & -2.46475 & 0.98010 \\
\hline $\mathrm{H}$ & 5.42886 & 0.92312 & -0.91552 \\
\hline $\mathrm{H}$ & 4.44701 & 1.61889 & 0.38317 \\
\hline $\mathrm{H}$ & 3.82529 & 1.58443 & -1.28269 \\
\hline $\mathrm{H}$ & 5.69823 & -1.25113 & 0.30755 \\
\hline $\mathrm{H}$ & 4.28831 & -2.13615 & 0.92139 \\
\hline $\mathrm{H}$ & 4.76572 & -0.60597 & 1.67178 \\
\hline $\mathrm{H}$ & 4.72815 & -1.29128 & -2.01775 \\
\hline
\end{tabular}




$\begin{array}{llll}\mathrm{H} & 3.11928 & -0.62580 & -2.35314 \\ \mathrm{H} & 3.29095 & -2.15359 & -1.45186\end{array}$

\section{$[2-O-P i v-\beta-x y l o(H 3) \bullet q u i n u c l i d i n e]^{++}($transition state for HAT)}

Energy (Hartree/particle): -1211.34758322

$\begin{array}{lc}\text { Zero-point correction }= & 0.496082 \\ \text { Thermal correction to Energy= }= & 0.523065 \\ \text { Thermal correction to Enthalpy= }= & 0.524009 \\ \text { Thermal correction to Gibbs Free Energy }= & 0.437036 \\ \text { Sum of electronic and zero-point Energies }= & -1210.851501 \\ \text { Sum of electronic and thermal Energies }= & -1210.824518 \\ \text { Sum of electronic and thermal Enthalpies }= & -1210.823574 \\ \text { Sum of electronic and thermal Free Energies }= & -1210.910547\end{array}$

Number of imaginary frequencies: $1,-394.3320$

\begin{tabular}{lrrr}
\multicolumn{4}{l}{ Geometry: } \\
$\mathrm{O}$ & -0.81239 & -4.15117 & 0.04834 \\
$\mathrm{C}$ & 0.43756 & -3.79023 & 0.68607 \\
$\mathrm{C}$ & 0.35945 & -2.27844 & 0.93254 \\
$\mathrm{O}$ & 1.55921 & -1.78805 & 1.52111 \\
$\mathrm{C}$ & 0.17632 & -1.45304 & -0.37031 \\
$\mathrm{H}$ & -0.82192 & -0.73566 & -0.17941 \\
$\mathrm{C}$ & 1.39705 & -0.54634 & -0.47185 \\
$\mathrm{C}$ & 2.38483 & -1.22733 & 0.51458 \\
$\mathrm{H}$ & 0.55133 & -4.30476 & 1.64638 \\
$\mathrm{H}$ & 1.29300 & -4.02114 & 0.04269 \\
$\mathrm{H}$ & -0.45248 & -2.08494 & 1.64431 \\
$\mathrm{O}$ & 1.06276 & 0.78080 & -0.00320 \\
$\mathrm{O}$ & -0.07430 & -2.14079 & -1.53551 \\
$\mathrm{H}$ & -0.82166 & -5.10554 & -0.10751 \\
$\mathrm{H}$ & -0.51116 & -2.99278 & -1.28482 \\
$\mathrm{H}$ & 3.04658 & -0.50005 & 1.00113 \\
$\mathrm{O}$ & 3.11053 & -2.24612 & -0.11100 \\
$\mathrm{H}$ & 1.78359 & -0.50147 & -1.48984 \\
$\mathrm{C}$ & 4.34710 & -1.80882 & -0.70297 \\
$\mathrm{H}$ & 4.81274 & -2.70082 & -1.12384 \\
$\mathrm{H}$ & 5.00324 & -1.37343 & 0.06211 \\
$\mathrm{H}$ & 4.17390 & -1.06881 & -1.49288 \\
$\mathrm{C}$ & 2.00910 & 1.73751 & -0.31155 \\
$\mathrm{C}$ & 1.67484 & 3.13399 & 0.21786 \\
$\mathrm{C}$ & 1.26812 & 3.98082 & -1.01032 \\
$\mathrm{C}$ & 2.96378 & 3.70993 & 0.83981
\end{tabular}




$\begin{array}{lrrr}\mathrm{C} & 0.54910 & 3.14652 & 1.26040 \\ \mathrm{O} & 2.99028 & 1.46918 & -0.96291 \\ \mathrm{H} & -3.48921 & 2.69094 & -1.11815 \\ \mathrm{H} & -3.37604 & 2.34595 & 1.40288 \\ \mathrm{H} & -1.42298 & 1.02800 & 1.53303 \\ \mathrm{H} & -1.37248 & 1.72448 & -0.80193 \\ \mathrm{C} & -3.61413 & 1.28269 & 1.29888 \\ \mathrm{C} & -3.55175 & 1.60059 & -1.17997 \\ \mathrm{C} & -2.30394 & 0.44055 & 1.27297 \\ \mathrm{C} & -2.11962 & 0.99258 & -1.10852 \\ \mathrm{C} & -4.37676 & 1.03411 & -0.01308 \\ \mathrm{H} & -4.02339 & 1.35135 & -2.13531 \\ \mathrm{H} & -4.21840 & 0.99418 & 2.16357 \\ \mathrm{H} & -5.35664 & 1.51835 & 0.02448 \\ \mathrm{~N} & -2.11730 & -0.08759 & -0.09632 \\ \mathrm{H} & -2.36176 & -0.41728 & 1.94758 \\ \mathrm{H} & -1.80526 & 0.55778 & -2.06063 \\ \mathrm{C} & -4.54629 & -0.48120 & -0.21444 \\ \mathrm{C} & -3.13425 & -1.11282 & -0.41539 \\ \mathrm{H} & -5.16882 & -0.69064 & -1.08878 \\ \mathrm{H} & -5.03822 & -0.92741 & 0.65522 \\ \mathrm{H} & -2.96996 & -1.97349 & 0.23786 \\ \mathrm{H} & -2.96872 & -1.42657 & -1.44864 \\ \mathrm{H} & 2.07102 & 4.00269 & -1.75154 \\ \mathrm{H} & 1.06081 & 5.00664 & -0.68931 \\ \mathrm{H} & 0.36457 & 3.58474 & -1.48860 \\ \mathrm{H} & 3.78341 & 3.70166 & 0.11855 \\ \mathrm{H} & 3.26892 & 3.13265 & 1.71932 \\ \mathrm{H} & 2.78275 & 4.74184 & 1.15604 \\ \mathrm{H} & -0.41137 & 2.85947 & 0.82266 \\ \mathrm{H} & 0.43843 & 4.16136 & 1.65495 \\ \mathrm{H} & 0.76536 & 2.47858 & 2.09979\end{array}$

$[2-O-P i v-\beta \text {-xylo(H4)•quinuclidine }]^{++}($transition state for HAT)

Energy (Hartree/particle): -1211.34843325

Zero-point correction $=$

Thermal correction to Energy=

Thermal correction to Enthalpy=

Thermal correction to Gibbs Free Energy=

Sum of electronic and zero-point Energies=

Sum of electronic and thermal Energies=

Sum of electronic and thermal Enthalpies=

Sum of electronic and thermal Free Energies=
0.495176 (Hartree/Particle)

0.522836

0.523780

0.435130

$-1210.853257$

$-1210.825598$

$-1210.824653$

$-1210.913303$ 
Number of imaginary frequencies: $1,-309.5824$

$\begin{array}{lccc}\text { Geometry: } & & \\ \mathrm{O} & -0.81239 & -4.15117 & 0.04834 \\ \mathrm{C} & 0.43756 & -3.79023 & 0.68607 \\ \mathrm{C} & 0.35945 & -2.27844 & 0.93254 \\ \mathrm{O} & 1.55921 & -1.78805 & 1.52111 \\ \mathrm{C} & 0.17632 & -1.45304 & -0.37031 \\ \mathrm{H} & -0.82192 & -0.73566 & -0.17941 \\ \mathrm{C} & 1.39705 & -0.54634 & -0.47185 \\ \mathrm{C} & 2.38483 & -1.22733 & 0.51458 \\ \mathrm{H} & 0.55133 & -4.30476 & 1.64638 \\ \mathrm{H} & 1.29300 & -4.02114 & 0.04269 \\ \mathrm{H} & -0.45248 & -2.08494 & 1.64431 \\ \mathrm{O} & 1.06276 & 0.78080 & -0.00320 \\ \mathrm{O} & -0.07430 & -2.14079 & -1.53551 \\ \mathrm{H} & -0.82166 & -5.10554 & -0.10751 \\ \mathrm{H} & -0.51116 & -2.99278 & -1.28482 \\ \mathrm{H} & 3.04658 & -0.50005 & 1.00113 \\ \mathrm{O} & 3.11053 & -2.24612 & -0.11100 \\ \mathrm{H} & 1.78359 & -0.50147 & -1.48984 \\ \mathrm{C} & 4.34710 & -1.80882 & -0.70297 \\ \mathrm{H} & 4.81274 & -2.70082 & -1.12384 \\ \mathrm{H} & 5.00324 & -1.37343 & 0.06211 \\ \mathrm{H} & 4.17390 & -1.06881 & -1.49288 \\ \mathrm{C} & 2.00910 & 1.73751 & -0.31155 \\ \mathrm{C} & 1.67484 & 3.13399 & 0.21786 \\ \mathrm{C} & 1.26812 & 3.98082 & -1.01032 \\ \mathrm{C} & 2.96378 & 3.70993 & 0.83981 \\ \mathrm{C} & 0.54910 & 3.14652 & 1.26040 \\ \mathrm{O} & 2.99028 & 1.46918 & -0.96291 \\ \mathrm{H} & -3.48921 & 2.69094 & -1.11815 \\ \mathrm{H} & -3.37604 & 2.34595 & 1.40288 \\ \mathrm{H} & -1.42298 & 1.02800 & 1.53303 \\ \mathrm{H} & -1.37248 & 1.72448 & -0.80193 \\ \mathrm{C} & -3.61413 & 1.28269 & 1.29888 \\ \mathrm{C} & -3.55175 & 1.60059 & -1.17997 \\ \mathrm{C} & -2.30394 & 0.44055 & 1.27297 \\ \mathrm{C} & -2.11962 & 0.99258 & -1.10852 \\ \mathrm{C} & -4.37676 & 1.03411 & -0.01308 \\ \mathrm{H} & -4.02339 & 1.35135 & -2.13531 \\ \mathrm{H} & -4.21840 & 0.99418 & 2.16357 \\ \mathrm{H} & -5.35664 & 1.51835 & 0.02448 \\ \mathrm{~N} & -2.11730 & -0.08759 & -0.09632 \\ \mathrm{H} & -2.36176 & -0.41728 & 1.94758 \\ & & & \end{array}$




$\begin{array}{lrrr}\mathrm{H} & -1.80526 & 0.55778 & -2.06063 \\ \mathrm{C} & -4.54629 & -0.48120 & -0.21444 \\ \mathrm{C} & -3.13425 & -1.11282 & -0.41539 \\ \mathrm{H} & -5.16882 & -0.69064 & -1.08878 \\ \mathrm{H} & -5.03822 & -0.92741 & 0.65522 \\ \mathrm{H} & -2.96996 & -1.97349 & 0.23786 \\ \mathrm{H} & -2.96872 & -1.42657 & -1.44864 \\ \mathrm{H} & 2.07102 & 4.00269 & -1.75154 \\ \mathrm{H} & 1.06081 & 5.00664 & -0.68931 \\ \mathrm{H} & 0.36457 & 3.58474 & -1.48860 \\ \mathrm{H} & 3.78341 & 3.70166 & 0.11855 \\ \mathrm{H} & 3.26892 & 3.13265 & 1.71932 \\ \mathrm{H} & 2.78275 & 4.74184 & 1.15604 \\ \mathrm{H} & -0.41137 & 2.85947 & 0.82266 \\ \mathrm{H} & 0.43843 & 4.16136 & 1.65495 \\ \mathrm{H} & 0.76536 & 2.47858 & 2.09979\end{array}$

$[2-O-P i v-\beta-x y l o(H 5) \bullet q u i n u c l i d i n e]^{\bullet+}($ transition state for HAT)

Energy (Hartree/particle): -1211.34225793

Zero-point correction $=$

Thermal correction to Energy=

Thermal correction to Enthalpy=

Thermal correction to Gibbs Free Energy=

Sum of electronic and zero-point Energies $=$

Sum of electronic and thermal Energies=

Sum of electronic and thermal Enthalpies=

Sum of electronic and thermal Free Energies=
0.494849 (Hartree/Particle)

0.522637

0.523582

Number of imaginary frequencies: $1,-809.0701$

\section{Geometry:}

$\begin{array}{lrrr}\mathrm{O} & -2.10751 & -2.89671 & -1.60742 \\ \mathrm{C} & -1.38743 & -3.15616 & -0.39854 \\ \mathrm{C} & -0.47366 & -1.96425 & -0.18129 \\ \mathrm{O} & 0.19770 & -2.03130 & 1.01683 \\ \mathrm{C} & 0.50835 & -1.58799 & -1.31512 \\ \mathrm{H} & 0.07712 & -0.84933 & -1.99822 \\ \mathrm{C} & 1.68420 & -0.97822 & -0.54138 \\ \mathrm{C} & 1.62325 & -1.61109 & 0.85495 \\ \mathrm{H} & -2.05929 & -3.27422 & 0.46365 \\ \mathrm{H} & -0.76522 & -4.05906 & -0.47825 \\ \mathrm{H} & -1.26243 & -0.99534 & -0.09699 \\ \mathrm{O} & 1.47539 & 0.44745 & -0.48590\end{array}$




\begin{tabular}{|c|c|c|c|}
\hline $\mathrm{O}$ & 0.96484 & -2.73169 & -2.01288 \\
\hline $\mathrm{H}$ & -2.64443 & -3.67212 & -1.81816 \\
\hline $\mathrm{H}$ & 0.26861 & -2.99762 & -2.63148 \\
\hline $\mathrm{H}$ & 1.80488 & -0.90450 & 1.67262 \\
\hline $\mathrm{O}$ & 2.42816 & -2.71325 & 0.90537 \\
\hline $\mathrm{H}$ & 2.63833 & -1.20685 & -1.01660 \\
\hline $\mathrm{C}$ & 2.68203 & -3.22582 & 2.22776 \\
\hline $\mathrm{H}$ & 3.41637 & -4.02244 & 2.10506 \\
\hline $\mathrm{H}$ & 1.76521 & -3.62967 & 2.67113 \\
\hline $\mathrm{H}$ & 3.09446 & -2.43445 & 2.86677 \\
\hline $\mathrm{C}$ & 2.59585 & 1.17596 & -0.10446 \\
\hline $\mathrm{C}$ & 2.40376 & 2.67983 & -0.30531 \\
\hline $\mathrm{C}$ & 3.61988 & 3.41036 & 0.28246 \\
\hline $\mathrm{C}$ & 1.11793 & 3.16787 & 0.38819 \\
\hline $\mathrm{C}$ & 2.31227 & 2.94547 & -1.82521 \\
\hline $\mathrm{O}$ & 3.59138 & 0.62890 & 0.29561 \\
\hline $\mathrm{H}$ & -4.29778 & 2.95984 & 0.80149 \\
\hline $\mathrm{C}$ & -3.65383 & 2.09923 & 0.59907 \\
\hline $\mathrm{H}$ & -3.70997 & 2.38451 & -1.55815 \\
\hline $\mathrm{H}$ & -5.01615 & 0.68103 & 1.53158 \\
\hline $\mathrm{H}$ & -1.97335 & 2.89510 & 1.72931 \\
\hline $\mathrm{H}$ & -5.25071 & 0.86336 & -0.20759 \\
\hline $\mathrm{H}$ & -2.34079 & 3.16672 & -0.76565 \\
\hline $\mathrm{H}$ & -3.04104 & 1.85281 & 2.67223 \\
\hline $\mathrm{C}$ & -2.96602 & 2.26877 & -0.76470 \\
\hline $\mathrm{C}$ & -4.49301 & 0.81120 & 0.57981 \\
\hline $\mathrm{C}$ & -2.57707 & 1.98355 & 1.69026 \\
\hline $\mathrm{C}$ & -2.09062 & 1.00967 & -1.03856 \\
\hline $\mathrm{C}$ & -3.54464 & -0.40097 & 0.32554 \\
\hline $\mathrm{C}$ & -1.66664 & 0.76265 & 1.36260 \\
\hline $\mathrm{N}$ & -2.16929 & 0.10967 & 0.13432 \\
\hline $\mathrm{H}$ & -2.44019 & 0.44376 & -1.90522 \\
\hline $\mathrm{H}$ & -3.52538 & -1.08668 & 1.17631 \\
\hline $\mathrm{H}$ & -0.63313 & 1.05592 & 1.17620 \\
\hline $\mathrm{H}$ & -3.81460 & -0.96522 & -0.56900 \\
\hline $\mathrm{H}$ & -1.03964 & 1.26281 & -1.18855 \\
\hline $\mathrm{H}$ & -1.67424 & 0.01463 & 2.15892 \\
\hline $\mathrm{H}$ & 2.21931 & 4.02265 & -1.99733 \\
\hline $\mathrm{H}$ & 1.44481 & 2.44779 & -2.26903 \\
\hline $\mathrm{H}$ & 3.21366 & 2.59752 & -2.33953 \\
\hline $\mathrm{H}$ & 1.11947 & 2.92011 & 1.45573 \\
\hline $\mathrm{H}$ & 0.22530 & 2.74000 & -0.07428 \\
\hline $\mathrm{H}$ & 1.05283 & 4.25677 & 0.29825 \\
\hline $\mathrm{H}$ & 3.70946 & 3.23066 & 1.35782 \\
\hline $\mathrm{H}$ & 3.50915 & 4.48679 & 0.11879 \\
\hline $\mathrm{H}$ & 4.54684 & 3.07958 & -0.19149 \\
\hline
\end{tabular}




\section{[2-O-Piv- $\alpha$-xylo]}

Energy (Hartree/particle): -882.367488820

$\begin{array}{lc}\text { Zero-point correction }= & 0.306327 \text { (Hartree/Particle }) \\ \text { Thermal correction to Energy= } & 0.325954 \\ \text { Thermal correction to Enthalpy= } & 0.326898 \\ \text { Thermal correction to Gibbs Free Energy }= & 0.256532 \\ \text { Sum of electronic and zero-point Energies }= & -882.061162 \\ \text { Sum of electronic and thermal Energies }= & -882.041535 \\ \text { Sum of electronic and thermal Enthalpies }= & -882.040591 \\ \text { Sum of electronic and thermal Free Energies }= & -882.110957\end{array}$

Number of imaginary frequencies: 0

\begin{tabular}{lrrr}
\multicolumn{4}{l}{ Geometry: } \\
$\mathrm{O}$ & 3.40709 & -2.39998 & 0.72321 \\
$\mathrm{C}$ & 3.41073 & -0.97255 & 0.91174 \\
$\mathrm{C}$ & 1.97957 & -0.48389 & 0.72642 \\
$\mathrm{O}$ & 2.00123 & 0.95161 & 0.66923 \\
$\mathrm{C}$ & 1.31385 & -0.97023 & -0.58244 \\
$\mathrm{H}$ & 0.73414 & -1.88679 & -0.42226 \\
$\mathrm{C}$ & 0.39507 & 0.20797 & -0.91011 \\
$\mathrm{C}$ & 1.22650 & 1.41221 & -0.45702 \\
$\mathrm{H}$ & 3.76743 & -0.70593 & 1.91589 \\
$\mathrm{H}$ & 4.04953 & -0.47552 & 0.16893 \\
$\mathrm{H}$ & 1.35901 & -0.80122 & 1.57734 \\
$\mathrm{O}$ & -0.77729 & 0.13706 & -0.08258 \\
$\mathrm{O}$ & 2.22773 & -1.11983 & -1.66410 \\
$\mathrm{H}$ & 4.27941 & -2.73753 & 0.96136 \\
$\mathrm{H}$ & 2.81029 & -1.85577 & -1.42184 \\
$\mathrm{H}$ & 0.12034 & 0.23772 & -1.96510 \\
$\mathrm{C}$ & -1.88191 & -0.45992 & -0.61346 \\
$\mathrm{C}$ & -3.04590 & -0.41373 & 0.38405 \\
$\mathrm{C}$ & -2.61276 & -1.07871 & 1.70663 \\
$\mathrm{C}$ & -4.24530 & -1.16094 & -0.21201 \\
$\mathrm{C}$ & -3.41274 & 1.06441 & 0.63663 \\
$\mathrm{O}$ & -1.91357 & -0.93984 & -1.72325 \\
$\mathrm{H}$ & -3.71713 & 1.55540 & -0.29430 \\
$\mathrm{H}$ & -2.56751 & 1.61529 & 1.05648 \\
$\mathrm{H}$ & -4.25278 & 1.11530 & 1.33876 \\
$\mathrm{H}$ & -4.56019 & -0.71172 & -1.15794 \\
$\mathrm{H}$ & -5.08508 & -1.12169 & 0.49046 \\
$\mathrm{H}$ & -4.00221 & -2.21008 & -0.40522
\end{tabular}




$\begin{array}{lrrr}\mathrm{H} & -3.45738 & -1.08277 & 2.40476 \\ \mathrm{H} & -1.78268 & -0.53923 & 2.16944 \\ \mathrm{H} & -2.30485 & -2.11767 & 1.54220 \\ \mathrm{O} & 0.42420 & 2.49274 & -0.11763 \\ \mathrm{H} & 1.93216 & 1.69858 & -1.25667 \\ \mathrm{C} & 1.15940 & 3.69245 & 0.12593 \\ \mathrm{H} & 0.42145 & 4.48477 & 0.27259 \\ \mathrm{H} & 1.79831 & 3.94351 & -0.73522 \\ \mathrm{H} & 1.78350 & 3.59876 & 1.02326\end{array}$

\section{$[2-O-P i v-\alpha \text {-xylo(H2)•quinuclidine }]^{\bullet+}($ transition state for HAT)}

Energy (Hartree/particle): -1211.33656009

$\begin{array}{lc}\text { Zero-point correction }= & 0.494992(\text { Hartree/Particle) } \\ \text { Thermal correction to Energy= } & 0.522614 \\ \text { Thermal correction to Enthalpy= } & 0.523559 \\ \text { Thermal correction to Gibbs Free Energy= } & 0.435421 \\ \text { Sum of electronic and zero-point Energies }= & -1210.841568 \\ \text { Sum of electronic and thermal Energies }= & -1210.813946 \\ \text { Sum of electronic and thermal Enthalpies }= & -1210.813002 \\ \text { Sum of electronic and thermal Free Energies }= & -1210.901139\end{array}$

Number of imaginary frequencies: $1,-1305.5759$

\begin{tabular}{lrrr}
\multicolumn{4}{l}{ Geometry: } \\
$\mathrm{O}$ & 3.40709 & -2.39998 & 0.72321 \\
$\mathrm{C}$ & 3.41073 & -0.97255 & 0.91174 \\
$\mathrm{C}$ & 1.97957 & -0.48389 & 0.72642 \\
$\mathrm{O}$ & 2.00123 & 0.95161 & 0.66923 \\
$\mathrm{C}$ & 1.31385 & -0.97023 & -0.58244 \\
$\mathrm{H}$ & 0.73414 & -1.88679 & -0.42226 \\
$\mathrm{C}$ & 0.39507 & 0.20797 & -0.91011 \\
$\mathrm{C}$ & 1.22650 & 1.41221 & -0.45702 \\
$\mathrm{H}$ & 3.76743 & -0.70593 & 1.91589 \\
$\mathrm{H}$ & 4.04953 & -0.47552 & 0.16893 \\
$\mathrm{H}$ & 1.35901 & -0.80122 & 1.57734 \\
$\mathrm{O}$ & -0.77729 & 0.13706 & -0.08258 \\
$\mathrm{O}$ & 2.22773 & -1.11983 & -1.66410 \\
$\mathrm{H}$ & 4.27941 & -2.73753 & 0.96136 \\
$\mathrm{H}$ & 2.81029 & -1.85577 & -1.42184 \\
$\mathrm{H}$ & 0.12034 & 0.23772 & -1.96510 \\
$\mathrm{C}$ & -1.88191 & -0.45992 & -0.61346 \\
$\mathrm{C}$ & -3.04590 & -0.41373 & 0.38405 \\
$\mathrm{C}$ & -2.61276 & -1.07871 & 1.70663
\end{tabular}




$\begin{array}{lrrr}\mathrm{C} & -4.24530 & -1.16094 & -0.21201 \\ \mathrm{C} & -3.41274 & 1.06441 & 0.63663 \\ \mathrm{O} & -1.91357 & -0.93984 & -1.72325 \\ \mathrm{H} & -3.71713 & 1.55540 & -0.29430 \\ \mathrm{H} & -2.56751 & 1.61529 & 1.05648 \\ \mathrm{H} & -4.25278 & 1.11530 & 1.33876 \\ \mathrm{H} & -4.56019 & -0.71172 & -1.15794 \\ \mathrm{H} & -5.08508 & -1.12169 & 0.49046 \\ \mathrm{H} & -4.00221 & -2.21008 & -0.40522 \\ \mathrm{H} & -3.45738 & -1.08277 & 2.40476 \\ \mathrm{H} & -1.78268 & -0.53923 & 2.16944 \\ \mathrm{H} & -2.30485 & -2.11767 & 1.54220 \\ \mathrm{O} & 0.42420 & 2.49274 & -0.11763 \\ \mathrm{H} & 1.93216 & 1.69858 & -1.25667 \\ \mathrm{C} & 1.15940 & 3.69245 & 0.12593 \\ \mathrm{H} & 0.42145 & 4.48477 & 0.27259 \\ \mathrm{H} & 1.79831 & 3.94351 & -0.73522 \\ \mathrm{H} & 1.78350 & 3.59876 & 1.02326\end{array}$

$[2-O-P i v-\alpha-x y l o(H 3) \bullet q u i n u c l i d i n e]^{++}($transition state for HAT)

Energy (Hartree/particle): -1211.34308069

$\begin{array}{lc}\text { Zero-point correction }= & 0.495588 \text { (Hartree/Particle) } \\ \text { Thermal correction to Energy= } & 0.522788 \\ \text { Thermal correction to Enthalpy= } & 0.523732 \\ \text { Thermal correction to Gibbs Free Energy= } & 0.435237 \\ \text { Sum of electronic and zero-point Energies }= & -1210.847493 \\ \text { Sum of electronic and thermal Energies }= & -1210.820293 \\ \text { Sum of electronic and thermal Enthalpies }= & -1210.819349 \\ \text { Sum of electronic and thermal Free Energies }= & -1210.907844\end{array}$

Number of imaginary frequencies: $1,-440.5216$

\begin{tabular}{lccc}
\multicolumn{4}{l}{ Geometry: } \\
$\mathrm{H}$ & 1.98548 & 4.30675 & -1.44730 \\
$\mathrm{O}$ & 1.49313 & 1.77869 & -1.94205 \\
$\mathrm{H}$ & 1.45193 & -0.43450 & -1.85882 \\
$\mathrm{O}$ & -0.30204 & -2.20313 & -1.69280 \\
$\mathrm{C}$ & 1.37603 & 4.22317 & -0.54524 \\
$\mathrm{H}$ & -0.80141 & -3.00494 & -1.40417 \\
$\mathrm{H}$ & 0.32286 & 4.28275 & -0.84238 \\
$\mathrm{C}$ & 1.43773 & 1.73806 & -0.73830 \\
$\mathrm{C}$ & 1.31587 & -0.65280 & -0.79856 \\
$\mathrm{H}$ & 3.80158 & 2.91238 & -0.30258
\end{tabular}




\begin{tabular}{|c|c|c|c|}
\hline $\mathrm{C}$ & 0.10785 & -1.55074 & -0.55213 \\
\hline $\mathrm{H}$ & 2.73669 & -2.29390 & -0.91605 \\
\hline $\mathrm{H}$ & 1.59501 & 5.07496 & 0.10603 \\
\hline $\mathrm{H}$ & -0.83802 & -0.81239 & -0.21888 \\
\hline $\mathrm{C}$ & 1.67039 & 2.91697 & 0.20723 \\
\hline $\mathrm{C}$ & 2.44806 & -1.50376 & -0.19849 \\
\hline $\mathrm{C}$ & 3.17081 & 2.85071 & 0.58915 \\
\hline $\mathrm{O}$ & 1.19771 & 0.56226 & -0.04739 \\
\hline $\mathrm{H}$ & 4.98485 & -2.13434 & -0.38446 \\
\hline $\mathrm{O}$ & 3.51998 & -0.74474 & 0.17358 \\
\hline $\mathrm{H}$ & 3.40891 & 3.69852 & 1.23984 \\
\hline $\mathrm{O}$ & -1.09985 & -4.09500 & 0.01976 \\
\hline $\mathrm{C}$ & 4.71367 & -1.49538 & 0.46676 \\
\hline $\mathrm{H}$ & 0.96905 & -4.27583 & -0.31791 \\
\hline $\mathrm{C}$ & 0.47454 & -2.42176 & 0.68749 \\
\hline $\mathrm{H}$ & 3.40127 & 1.92250 & 1.11831 \\
\hline $\mathrm{C}$ & 0.27025 & -3.92205 & 0.45165 \\
\hline $\mathrm{H}$ & -1.28955 & -5.03965 & -0.06288 \\
\hline $\mathrm{O}$ & 1.83748 & -2.14380 & 0.96672 \\
\hline $\mathrm{C}$ & 0.81601 & 2.83710 & 1.48299 \\
\hline $\mathrm{H}$ & 5.49974 & -0.75834 & 0.63631 \\
\hline $\mathrm{H}$ & -0.25422 & 2.89962 & 1.25146 \\
\hline $\mathrm{H}$ & 4.57486 & -2.10675 & 1.36471 \\
\hline $\mathrm{H}$ & 1.05608 & 3.68870 & 2.12714 \\
\hline $\mathrm{H}$ & -0.11762 & -2.11524 & 1.55980 \\
\hline $\mathrm{H}$ & 1.00889 & 1.92036 & 2.04521 \\
\hline $\mathrm{H}$ & 0.46023 & -4.46572 & 1.38321 \\
\hline $\mathrm{H}$ & -5.17108 & 1.71344 & 0.43566 \\
\hline $\mathrm{C}$ & -4.22998 & 1.17325 & 0.29955 \\
\hline $\mathrm{H}$ & -4.97559 & -0.80135 & 0.82825 \\
\hline $\mathrm{H}$ & -3.06156 & 2.27604 & 1.76574 \\
\hline $\mathrm{H}$ & -3.95079 & 1.63878 & -1.80655 \\
\hline $\mathrm{H}$ & -3.96811 & 0.92666 & 2.45354 \\
\hline $\mathrm{H}$ & -5.19826 & -0.39095 & -0.87428 \\
\hline $\mathrm{H}$ & -3.30183 & 2.86685 & -0.71805 \\
\hline $\mathrm{C}$ & -4.51143 & -0.30249 & -0.02801 \\
\hline $\mathrm{C}$ & -3.38723 & 1.24706 & 1.58410 \\
\hline $\mathrm{C}$ & -3.42730 & 1.78934 & -0.85765 \\
\hline $\mathrm{C}$ & -3.15860 & -0.99260 & -0.38291 \\
\hline $\mathrm{C}$ & -2.14897 & 0.31589 & 1.41536 \\
\hline $\mathrm{C}$ & -2.02668 & 1.10993 & -0.89782 \\
\hline $\mathrm{N}$ & -2.06040 & -0.07438 & -0.00897 \\
\hline $\mathrm{H}$ & -3.01752 & -1.93112 & 0.15884 \\
\hline $\mathrm{H}$ & -1.21590 & 0.80838 & 1.69097 \\
\hline $\mathrm{H}$ & -1.74973 & 0.77694 & -1.90060 \\
\hline $\mathrm{H}$ & -2.24872 & -0.60215 & 1.99962 \\
\hline
\end{tabular}




$\begin{array}{llrr}\mathrm{H} & -3.06735 & -1.19059 & -1.45331 \\ \mathrm{H} & -1.24470 & 1.77113 & -0.52740\end{array}$

\section{$[2-O \text {-Piv- } \alpha \text {-xylo(H4)•quinuclidine }]^{\bullet+}($ transition state for HAT)}

Energy (Hartree/particle): -1211.35011305

$\begin{array}{lc}\text { Zero-point correction }= & 0.495510 \text { (Hartree/Particle) } \\ \text { Thermal correction to Energy= } & 0.523110 \\ \text { Thermal correction to Enthalpy= } & 0.524054 \\ \text { Thermal correction to Gibbs Free Energy }= & 0.436171 \\ \text { Sum of electronic and zero-point Energies }= & -1210.854603 \\ \text { Sum of electronic and thermal Energies }= & -1210.827003 \\ \text { Sum of electronic and thermal Enthalpies }= & -1210.826059 \\ \text { Sum of electronic and thermal Free Energies }= & -1210.913942\end{array}$

Number of imaginary frequencies: $\mathbf{1 ,}-\mathbf{- 3 5 7 . 4 1 6 3}$

\begin{tabular}{lrrr}
\multicolumn{4}{l}{ Geometry: } \\
$\mathrm{O}$ & 2.94044 & 2.26505 & -1.61508 \\
$\mathrm{C}$ & 2.45678 & 2.70629 & -0.34362 \\
$\mathrm{C}$ & 1.16526 & 1.95131 & -0.09610 \\
$\mathrm{O}$ & 0.61833 & 2.26152 & 1.12431 \\
$\mathrm{C}$ & 0.05904 & 2.01928 & -1.16984 \\
$\mathrm{H}$ & 0.21044 & 1.28836 & -1.96870 \\
$\mathrm{C}$ & -1.20509 & 1.70135 & -0.36528 \\
$\mathrm{C}$ & -0.85553 & 2.03751 & 1.10711 \\
$\mathrm{H}$ & 3.17266 & 2.49835 & 0.46458 \\
$\mathrm{H}$ & 2.24019 & 3.78413 & -0.33940 \\
$\mathrm{H}$ & 1.51345 & 0.74682 & -0.07198 \\
$\mathrm{O}$ & -1.53147 & 0.31955 & -0.54388 \\
$\mathrm{O}$ & -0.06139 & 3.33744 & -1.68361 \\
$\mathrm{H}$ & 3.72918 & 2.77677 & -1.83851 \\
$\mathrm{H}$ & 0.63143 & 3.46393 & -2.34818 \\
$\mathrm{O}$ & -1.19557 & 1.02682 & 1.96296 \\
$\mathrm{H}$ & -2.03732 & 2.32339 & -0.69698 \\
$\mathrm{C}$ & -2.87083 & 0.00777 & -0.33317 \\
$\mathrm{C}$ & -3.15721 & -1.46936 & -0.60594 \\
$\mathrm{C}$ & -4.63105 & -1.74834 & -0.27759 \\
$\mathrm{C}$ & -2.25189 & -2.35570 & 0.27220 \\
$\mathrm{C}$ & -2.88843 & -1.75729 & -2.09920 \\
$\mathrm{O}$ & -3.67108 & 0.84388 & -0.00557 \\
$\mathrm{H}$ & 2.90886 & -4.10429 & 0.39578 \\
$\mathrm{C}$ & 2.61836 & -3.05509 & 0.28957 \\
$\mathrm{H}$ & 2.46735 & -3.16289 & -1.87880
\end{tabular}




$\begin{array}{llll}\mathrm{H} & 4.44485 & -2.30313 & 1.20335 \\ \mathrm{H} & 0.81358 & -3.26354 & 1.48571 \\ \mathrm{H} & 4.52365 & -2.43193 & -0.55480 \\ \mathrm{H} & 0.94531 & -3.46355 & -1.03723 \\ \mathrm{H} & 2.23440 & -2.77548 & 2.41249 \\ \mathrm{C} & 1.85372 & -2.85374 & -1.02767 \\ \mathrm{C} & 3.87169 & -2.16463 & 0.28203 \\ \mathrm{C} & 1.71296 & -2.64111 & 1.46025 \\ \mathrm{C} & 1.48208 & -1.34699 & -1.16122 \\ \mathrm{C} & 3.42768 & -0.67397 & 0.15278 \\ \mathrm{C} & 1.31280 & -1.14626 & 1.27773 \\ \mathrm{~N} & 1.95303 & -0.63177 & 0.04696 \\ \mathrm{H} & 1.96278 & -0.87837 & -2.02310 \\ \mathrm{H} & 3.71243 & -0.08885 & 1.03077 \\ \mathrm{H} & 0.23671 & -1.00853 & 1.17508 \\ \mathrm{H} & 3.83683 & -0.19057 & -0.73625 \\ \mathrm{H} & 0.40507 & -1.19144 & -1.23325 \\ \mathrm{H} & 1.65472 & -0.52368 & 2.10779 \\ \mathrm{H} & -3.12811 & -2.80391 & -2.31346 \\ \mathrm{H} & -1.84115 & -1.58282 & -2.36344 \\ \mathrm{H} & -3.51550 & -1.12914 & -2.73992 \\ \mathrm{H} & -2.35385 & -2.10287 & 1.33270 \\ \mathrm{H} & -1.20118 & -2.25794 & -0.01037 \\ \mathrm{H} & -2.54039 & -3.40373 & 0.14283 \\ \mathrm{H} & -4.84629 & -1.54977 & 0.77609 \\ \mathrm{H} & -4.85606 & -2.79881 & -0.48686 \\ \mathrm{H} & -5.29536 & -1.12339 & -0.87927 \\ \mathrm{C} & -1.30235 & 1.41468 & 3.34717 \\ \mathrm{H} & -1.64983 & 0.53026 & 3.88296 \\ \mathrm{H} & -2.03390 & 2.22378 & 3.45950 \\ \mathrm{H} & -0.32899 & 1.73110 & 3.73884 \\ \mathrm{H} & -1.26929 & 3.00571 & 1.41495\end{array}$

$[2-O-P i v-\alpha-x y l o(H 5) \bullet q u i n u c l i d i n e]^{++}(\operatorname{transition}$ state for HAT)

Energy (Hartree/particle): -1211.33914000

Zero-point correction $=$

Thermal correction to Energy=

Thermal correction to Enthalpy=

Thermal correction to Gibbs Free Energy $=\quad 0.432709$

Sum of electronic and zero-point Energies $=\quad-1210.844443$

Sum of electronic and thermal Energies $=\quad-1210.816682$

Sum of electronic and thermal Enthalpies $=\quad-1210.815738$

Sum of electronic and thermal Free Energies $=\quad-1210.906431$ 
Number of imaginary frequencies: $\mathbf{1},-654.4317$

\begin{tabular}{lccc} 
Geometry: & & \\
$\mathrm{H}$ & -6.50114 & -0.04815 & -0.84191 \\
$\mathrm{O}$ & -4.37373 & 1.15216 & 0.36527 \\
$\mathrm{H}$ & -2.71830 & 0.73967 & 2.03600 \\
$\mathrm{O}$ & -0.96281 & 2.66193 & 1.73483 \\
$\mathrm{C}$ & -5.80282 & -0.11000 & -1.68056 \\
$\mathrm{H}$ & -1.78307 & 3.08875 & 2.01898 \\
$\mathrm{H}$ & -5.68139 & 0.89640 & -2.09193 \\
$\mathrm{C}$ & -3.85934 & 0.18858 & -0.15108 \\
$\mathrm{C}$ & -1.98254 & 0.47860 & 1.27106 \\
$\mathrm{H}$ & -5.33673 & -2.08994 & 0.20442 \\
$\mathrm{C}$ & -1.28602 & 1.73339 & 0.70916 \\
$\mathrm{H}$ & -0.63201 & -0.07293 & 2.89481 \\
$\mathrm{H}$ & -6.24257 & -0.74918 & -2.45268 \\
$\mathrm{H}$ & -1.87268 & 2.19371 & -0.09260 \\
$\mathrm{C}$ & -4.45626 & -0.69920 & -1.24055 \\
$\mathrm{C}$ & -0.81788 & -0.34664 & 1.84558 \\
$\mathrm{C}$ & -4.65939 & -2.11490 & -0.65574 \\
$\mathrm{O}$ & -2.60306 & -0.25159 & 0.21343 \\
$\mathrm{H}$ & -0.17139 & -2.21377 & 3.55067 \\
$\mathrm{O}$ & -1.03697 & -1.70092 & 1.71501 \\
$\mathrm{H}$ & -5.10756 & -2.75769 & -1.42059 \\
$\mathrm{O}$ & 1.08192 & 2.83805 & -1.08418 \\
$\mathrm{C}$ & -0.15573 & -2.51660 & 2.49423 \\
$\mathrm{H}$ & 1.40708 & 2.60171 & 0.97137 \\
$\mathrm{C}$ & 0.01195 & 1.10145 & 0.17155 \\
$\mathrm{H}$ & -3.71018 & -2.55561 & -0.34001 \\
$\mathrm{C}$ & 1.17505 & 2.05605 & 0.05055 \\
$\mathrm{H}$ & 1.50876 & 3.69502 & -0.93659 \\
$\mathrm{O}$ & 0.37208 & 0.08349 & 1.10816 \\
$\mathrm{C}$ & -3.48652 & -0.76114 & -2.43963 \\
$\mathrm{H}$ & -0.52096 & -3.54096 & 2.40287 \\
$\mathrm{H}$ & -3.29176 & 0.23950 & -2.84240 \\
$\mathrm{H}$ & 0.87392 & -2.46112 & 2.11500 \\
$\mathrm{H}$ & -3.93845 & -1.36114 & -3.23609 \\
$\mathrm{H}$ & -0.20960 & 0.66549 & -0.81536 \\
$\mathrm{H}$ & -2.53467 & -1.22068 & -2.16005 \\
$\mathrm{H}$ & 2.15316 & 1.27500 & -0.09073 \\
$\mathrm{H}$ & 5.89641 & -2.00175 & -0.95352 \\
$\mathrm{C}$ & 5.08507 & -1.29335 & -0.76343 \\
$\mathrm{H}$ & 3.82968 & -2.13400 & -2.33394 \\
$\mathrm{H}$ & 6.34300 & 0.43389 & -1.19612 \\
$\mathrm{H}$ & 4.82695 & -1.96183 & 1.29371 \\
& & & \\
\hline
\end{tabular}




$\begin{array}{lrrr}\mathrm{H} & 5.38660 & -0.12262 & -2.57105 \\ \mathrm{H} & 3.49513 & -2.77581 & -0.72426 \\ \mathrm{H} & 5.87740 & -0.55445 & 1.12202 \\ \mathrm{C} & 3.75476 & -1.86736 & -1.27594 \\ \mathrm{C} & 5.36865 & 0.03228 & -1.48833 \\ \mathrm{C} & 4.96445 & -1.02541 & 0.74555 \\ \mathrm{C} & 2.64192 & -0.79228 & -1.08312 \\ \mathrm{C} & 4.24961 & 1.05221 & -1.11272 \\ \mathrm{C} & 3.73920 & -0.09288 & 0.99045 \\ \mathrm{~N} & 3.21806 & 0.34342 & -0.32517 \\ \mathrm{H} & 2.28317 & -0.39822 & -2.03720 \\ \mathrm{H} & 4.63249 & 1.86887 & -0.49519 \\ \mathrm{H} & 2.92063 & -0.59469 & 1.50771 \\ \mathrm{H} & 3.76571 & 1.47776 & -1.99545 \\ \mathrm{H} & 1.79088 & -1.16822 & -0.51336 \\ \mathrm{H} & 4.01062 & 0.80114 & 1.55733\end{array}$

Effect of coordination of the carbonyl to the radical at C-3.

[per-Me- $\alpha$-GIc_C3]

Energy (Hartree/particle): -996.185532513

$\begin{array}{lc}\text { Zero-point correction }= & 0.324443 \text { (Hartree/Particle) } \\ \text { Thermal correction to Energy }= & 0.347157 \\ \text { Thermal correction to Enthalpy= } & 0.348101 \\ \text { Thermal correction to Gibbs Free Energy= } & 0.268903 \\ \text { Sum of electronic and zero-point Energies }= & -995.861089 \\ \text { Sum of electronic and thermal Energies }= & -995.838376 \\ \text { Sum of electronic and thermal Enthalpies }= & -995.837432 \\ \text { Sum of electronic and thermal Free Energies }= & -995.916630\end{array}$

Number of imaginary frequencies: 0

\begin{tabular}{lrcc}
\multicolumn{4}{l}{ Geometry: } \\
$\mathrm{O}$ & 3.54410 & -1.44044 & -0.14184 \\
$\mathrm{C}$ & 2.86674 & -1.09691 & 0.80353 \\
$\mathrm{H}$ & 0.37395 & -1.51899 & -2.10123 \\
$\mathrm{H}$ & -0.26162 & -3.72664 & -1.60409 \\
$\mathrm{C}$ & 0.16036 & -1.18928 & -1.07279 \\
$\mathrm{H}$ & 2.07643 & -0.22924 & -1.32307 \\
$\mathrm{C}$ & -0.54412 & -3.39189 & -0.59372 \\
$\mathrm{O}$ & 1.72478 & -0.36928 & 0.71084 \\
$\mathrm{O}$ & -1.14922 & -0.65640 & -1.15922
\end{tabular}




$\begin{array}{lrrr}\mathrm{C} & 1.21672 & -0.11357 & -0.66206 \\ \mathrm{H} & -1.61155 & -3.14433 & -0.57801 \\ \mathrm{O} & 0.24878 & -2.27310 & -0.19004 \\ \mathrm{H} & 3.31375 & 1.67600 & -0.68717 \\ \mathrm{H} & -5.37030 & 0.09445 & 1.07738 \\ \mathrm{H} & -0.33654 & -4.18970 & 0.12327 \\ \mathrm{H} & -5.42262 & -1.66607 & 0.76107 \\ \mathrm{C} & -5.02511 & -0.71091 & 0.40684 \\ \mathrm{O} & -3.61322 & -0.81893 & 0.40851 \\ \mathrm{C} & 2.71580 & 2.20582 & -1.43718 \\ \mathrm{H} & 2.77429 & 1.67261 & -2.39465 \\ \mathrm{H} & -3.22080 & 1.20931 & 0.65505 \\ \mathrm{C} & -1.48460 & 0.17475 & -0.04198 \\ \mathrm{C} & -2.98341 & 0.37564 & -0.02672 \\ \mathrm{C} & 0.63197 & 1.23563 & -0.71365 \\ \mathrm{H} & -1.26658 & 2.19639 & -0.84276 \\ \mathrm{C} & -0.72539 & 1.50863 & -0.16778 \\ \mathrm{H} & 3.09554 & 3.22139 & -1.56377 \\ \mathrm{O} & 1.35594 & 2.35302 & -1.01276 \\ \mathrm{H} & -1.17849 & -0.30987 & 0.89386 \\ \mathrm{H} & -5.41407 & -0.51119 & -0.60591 \\ \mathrm{H} & -3.32574 & 0.64683 & -1.04114 \\ \mathrm{O} & -0.72393 & 2.08495 & 1.15812 \\ \mathrm{H} & -1.30677 & 3.99772 & 0.54895 \\ \mathrm{C} & -0.56273 & 3.49617 & 1.18995 \\ \mathrm{H} & 0.44065 & 3.80245 & 0.86657 \\ \mathrm{H} & -0.71990 & 3.80392 & 2.22810 \\ \mathrm{C} & 3.16610 & -1.41713 & 2.24819 \\ \mathrm{H} & 4.20080 & -1.74900 & 2.34554 \\ \mathrm{H} & 2.49564 & -2.22317 & 2.56780 \\ \mathrm{H} & 2.97224 & -0.55311 & 2.88945\end{array}$

[per-Me- $\alpha$-Glc_C3 _coord]

Energy (Hartree/particle): -996.179373191

$\begin{array}{lc}\text { Zero-point correction= } & 0.324630 \text { (Hartree/Particle) } \\ \text { Thermal correction to Energy= } & 0.346996 \\ \text { Thermal correction to Enthalpy= } & 0.347940 \\ \text { Thermal correction to Gibbs Free Energy= } & 0.271137 \\ \text { Sum of electronic and zero-point Energies }= & -995.854743 \\ \text { Sum of electronic and thermal Energies }= & -995.832377 \\ \text { Sum of electronic and thermal Enthalpies }= & -995.831433 \\ \text { Sum of electronic and thermal Free Energies }= & -995.908236\end{array}$


Number of imaginary frequencies: 0

\begin{tabular}{|c|c|c|c|}
\hline \multicolumn{4}{|c|}{ Geometry: } \\
\hline $\mathrm{O}$ & -2.28037 & 0.01084 & 1.42156 \\
\hline $\mathrm{C}$ & -2.73814 & 0.81971 & 0.64824 \\
\hline $\mathrm{H}$ & 0.03037 & 2.13356 & -1.78037 \\
\hline $\mathrm{H}$ & 0.70375 & 3.89435 & -0.37418 \\
\hline $\mathrm{C}$ & 0.06045 & 1.40771 & -0.95322 \\
\hline $\mathrm{H}$ & -1.29122 & 0.32132 & -2.20234 \\
\hline $\mathrm{C}$ & 0.82867 & 3.15722 & 0.43426 \\
\hline $\mathrm{O}$ & -2.34956 & 0.98782 & -0.64246 \\
\hline $\mathrm{O}$ & 1.30697 & 0.75962 & -1.09981 \\
\hline $\mathrm{C}$ & -1.08747 & 0.37722 & -1.12404 \\
\hline $\mathrm{H}$ & 1.86740 & 2.80634 & 0.44185 \\
\hline $\mathrm{O}$ & -0.08748 & 2.07173 & 0.27153 \\
\hline $\mathrm{H}$ & -3.32716 & -1.78766 & -0.45689 \\
\hline $\mathrm{H}$ & 5.48958 & -0.79543 & 0.71797 \\
\hline $\mathrm{H}$ & 0.58705 & 3.62159 & 1.39295 \\
\hline $\mathrm{H}$ & 5.83494 & 0.92511 & 0.36760 \\
\hline $\mathrm{C}$ & 5.23668 & 0.05990 & 0.06850 \\
\hline $\mathrm{O}$ & 3.87546 & 0.42678 & 0.19869 \\
\hline $\mathrm{C}$ & -2.79443 & -1.98082 & -1.39521 \\
\hline $\mathrm{H}$ & -3.04049 & -1.19695 & -2.12126 \\
\hline $\mathrm{H}$ & 3.14254 & -1.49385 & 0.51774 \\
\hline $\mathrm{C}$ & 1.56661 & -0.15997 & -0.02478 \\
\hline $\mathrm{C}$ & 2.99798 & -0.63165 & -0.15440 \\
\hline $\mathrm{C}$ & -0.73458 & -0.97403 & -0.64284 \\
\hline $\mathrm{H}$ & 0.98219 & -2.17621 & -0.63046 \\
\hline $\mathrm{C}$ & 0.57555 & -1.33723 & -0.03199 \\
\hline $\mathrm{H}$ & -3.08821 & -2.95228 & -1.79871 \\
\hline $\mathrm{O}$ & -1.38523 & -2.06817 & -1.15810 \\
\hline $\mathrm{H}$ & 1.44710 & 0.35538 & 0.93357 \\
\hline $\mathrm{H}$ & 5.48527 & -0.20807 & -0.97233 \\
\hline $\mathrm{H}$ & 3.18738 & -0.96245 & -1.19094 \\
\hline $\mathrm{O}$ & 0.52703 & -1.76368 & 1.34355 \\
\hline $\mathrm{H}$ & 0.02675 & -3.74950 & 0.91467 \\
\hline $\mathrm{C}$ & -0.25858 & -2.92132 & 1.58356 \\
\hline $\mathrm{H}$ & -1.32877 & -2.71406 & 1.45798 \\
\hline $\mathrm{H}$ & -0.06860 & -3.21154 & 2.62121 \\
\hline $\mathrm{C}$ & -3.84862 & 1.79279 & 0.97703 \\
\hline $\mathrm{H}$ & -4.33849 & 1.48949 & 1.90326 \\
\hline $\mathrm{H}$ & -4.57248 & 1.85635 & 0.15970 \\
\hline $\mathrm{H}$ & -3.40818 & 2.78776 & 1.10866 \\
\hline
\end{tabular}

[per-Me- $\alpha$-Man_C3] 
Energy (Hartree/particle): -996.182308693

Zero-point correction=

Thermal correction to Energy=

Thermal correction to Enthalpy=

Thermal correction to Gibbs Free Energy=

Sum of electronic and zero-point Energies=

Sum of electronic and thermal Energies=

Sum of electronic and thermal Enthalpies=

Sum of electronic and thermal Free Energies=
0.324463 (Hartree/Particle)

0.347095

0.348039

0.269596

$-995.857846$

$-995.835214$

$-995.834270$

$-995.912713$

\section{Number of imaginary frequencies: 0}

\begin{tabular}{lrcc}
\multicolumn{4}{l}{ Geometry: } \\
$\mathrm{H}$ & -0.95469 & -4.26609 & 1.05507 \\
$\mathrm{C}$ & -0.23956 & -3.45854 & 0.88101 \\
$\mathrm{H}$ & 0.21218 & -3.58483 & -0.11003 \\
$\mathrm{H}$ & 0.54471 & -3.47078 & 1.64275 \\
$\mathrm{O}$ & -1.00994 & -2.25553 & 0.95275 \\
$\mathrm{O}$ & 1.86058 & -1.54997 & 0.81036 \\
$\mathrm{H}$ & 0.88298 & -1.29387 & -1.00415 \\
$\mathrm{C}$ & -0.47185 & -1.03981 & 0.64780 \\
$\mathrm{C}$ & 0.87485 & -0.86621 & 0.01947 \\
$\mathrm{O}$ & -2.22689 & -0.28606 & -0.80420 \\
$\mathrm{C}$ & -1.52581 & -0.02268 & 0.49196 \\
$\mathrm{H}$ & -2.27924 & -0.09096 & 1.27943 \\
$\mathrm{C}$ & 1.24835 & 0.64187 & -0.06933 \\
$\mathrm{C}$ & 2.35054 & 0.97229 & -1.07538 \\
$\mathrm{H}$ & 1.58831 & 0.93641 & 0.93107 \\
$\mathrm{C}$ & -0.96347 & 1.39453 & 0.42322 \\
$\mathrm{O}$ & 0.13662 & 1.45501 & -0.47249 \\
$\mathrm{O}$ & -0.63639 & 1.77954 & 1.73303 \\
$\mathrm{H}$ & -1.70503 & 2.07797 & -0.01076 \\
$\mathrm{C}$ & -3.52114 & 0.10834 & -0.88165 \\
$\mathrm{O}$ & -4.11305 & 0.70075 & -0.00481 \\
$\mathrm{C}$ & -0.29493 & 3.16114 & 1.84946 \\
$\mathrm{H}$ & -0.12379 & 3.34971 & 2.91167 \\
$\mathrm{H}$ & -1.11822 & 3.79771 & 1.49168 \\
$\mathrm{H}$ & 0.61417 & 3.40006 & 1.28244 \\
$\mathrm{O}$ & 3.62424 & 0.79519 & -0.47312 \\
$\mathrm{H}$ & 2.21914 & 2.02142 & -1.38474 \\
$\mathrm{H}$ & 2.25841 & 0.34399 & -1.97896 \\
$\mathrm{C}$ & 4.68095 & 1.09979 & -1.36736 \\
$\mathrm{H}$ & 5.61681 & 0.95510 & -0.82094 \\
$\mathrm{H}$ & 4.62245 & 2.14349 & -1.71786
\end{tabular}




$\begin{array}{lrrr}\mathrm{H} & 4.66901 & 0.43618 & -2.24854 \\ \mathrm{C} & 2.85742 & -2.24401 & 0.06924 \\ \mathrm{H} & 3.51416 & -1.55454 & -0.47336 \\ \mathrm{H} & 2.40740 & -2.95803 & -0.63976 \\ \mathrm{H} & 3.45127 & -2.79992 & 0.80058 \\ \mathrm{C} & -4.11758 & -0.30089 & -2.21008 \\ \mathrm{H} & -4.13570 & -1.39363 & -2.28355 \\ \mathrm{H} & -3.50039 & 0.07270 & -3.03323 \\ \mathrm{H} & -5.13189 & 0.09150 & -2.29097 \\ \text { [per-Me- } \boldsymbol{\alpha} \text {-Man_C3 C.coord] } & \end{array}$

Energy (Hartree/particle): -996.184130182

$\begin{array}{lc}\text { Zero-point correction= } & 0.324426 \text { (Hartree/Particle) } \\ \text { Thermal correction to Energy= } & 0.347045 \\ \text { Thermal correction to Enthalpy= } & 0.347989 \\ \text { Thermal correction to Gibbs Free Energy= } & 0.270528 \\ \text { Sum of electronic and zero-point Energies }= & -995.859704 \\ \text { Sum of electronic and thermal Energies }= & -995.837086 \\ \text { Sum of electronic and thermal Enthalpies }= & -995.836141 \\ \text { Sum of electronic and thermal Free Energies }= & -995.913602\end{array}$

\section{Number of imaginary frequencies: 0}

\begin{tabular}{lrrr}
\multicolumn{4}{l}{ Geometry: } \\
$\mathrm{H}$ & 0.79372 & -1.47238 & -4.01060 \\
$\mathrm{C}$ & 0.23441 & -1.23052 & -3.10467 \\
$\mathrm{H}$ & 0.05164 & -2.14734 & -2.53107 \\
$\mathrm{H}$ & -0.71507 & -0.75274 & -3.36741 \\
$\mathrm{O}$ & 1.07022 & -0.33445 & -2.36460 \\
$\mathrm{O}$ & -1.58492 & 0.88151 & -1.64063 \\
$\mathrm{H}$ & -1.15308 & -0.99570 & -0.89357 \\
$\mathrm{C}$ & 0.61696 & 0.15028 & -1.17568 \\
$\mathrm{C}$ & -0.79756 & 0.03761 & -0.75675 \\
$\mathrm{O}$ & 2.68305 & -0.13057 & 0.24681 \\
$\mathrm{C}$ & 1.65389 & 0.79200 & -0.37979 \\
$\mathrm{H}$ & 2.30405 & 1.42069 & -0.99624 \\
$\mathrm{C}$ & -1.04109 & 0.41009 & 0.73852 \\
$\mathrm{C}$ & -1.56712 & -0.76140 & 1.56248 \\
$\mathrm{H}$ & -1.78825 & 1.21501 & 0.73058 \\
$\mathrm{C}$ & 1.05646 & 1.61164 & 0.76227 \\
$\mathrm{O}$ & 0.10873 & 0.85733 & 1.48079 \\
$\mathrm{O}$ & 0.53886 & 2.78987 & 0.19526 \\
$\mathrm{H}$ & 1.83279 & 1.84350 & 1.50678 \\
$\mathrm{C}$ & 2.39326 & -1.41485 & 0.52564 \\
$\mathrm{O}$ & 1.33655 & -1.97734 & 0.31920
\end{tabular}




$\begin{array}{lrrr}\mathrm{C} & 0.09133 & 3.73621 & 1.16408 \\ \mathrm{H} & -0.24275 & 4.61469 & 0.60745 \\ \mathrm{H} & 0.91016 & 4.02145 & 1.84316 \\ \mathrm{H} & -0.74114 & 3.34042 & 1.75964 \\ \mathrm{O} & -2.85327 & -1.12062 & 1.07582 \\ \mathrm{H} & -1.62609 & -0.45568 & 2.61978 \\ \mathrm{H} & -0.86587 & -1.60486 & 1.48307 \\ \mathrm{C} & -3.36424 & -2.27802 & 1.71383 \\ \mathrm{H} & -4.34549 & -2.48174 & 1.27583 \\ \mathrm{H} & -3.47883 & -2.12206 & 2.79944 \\ \mathrm{H} & -2.70663 & -3.14795 & 1.55393 \\ \mathrm{C} & -2.94313 & 0.47243 & -1.76227 \\ \mathrm{H} & -3.48797 & 0.54204 & -0.81130 \\ \mathrm{H} & -3.01823 & -0.56860 & -2.11840 \\ \mathrm{H} & -3.40131 & 1.13999 & -2.49772 \\ \mathrm{C} & 3.59945 & -2.08917 & 1.14947 \\ \mathrm{H} & 3.81343 & -1.63050 & 2.12098 \\ \mathrm{H} & 4.48283 & -1.95009 & 0.51887 \\ \mathrm{H} & 3.39272 & -3.15174 & 1.28290\end{array}$

Calculated free energies and geometries for Reaction Pathway.

\section{[HAT_PRC]•}

Energy (Hartree/particle): -2205.88499462

Zero-point correction $=$

Thermal correction to Energy=

Thermal correction to Enthalpy=

Thermal correction to Gibbs Free Energy=

Sum of electronic and zero-point Energies=

Sum of electronic and thermal Energies $=$

Sum of electronic and thermal Enthalpies $=$

Sum of electronic and thermal Free Energies=
0.621694 (Hartree/Particle)

0.661737

0.662681

0.542038

$-2205.263300$

$-2205.223258$

$-2205.222313$

$-2205.342957$

\section{Number of imaginary frequencies: 0}

\section{Geometry:}

$\begin{array}{lllr}\mathrm{O} & -2.42771 & 5.20735 & 1.37696 \\ \mathrm{H} & -2.09168 & 5.01060 & -0.61447 \\ \mathrm{C} & -1.70471 & 4.57695 & 0.31404 \\ \mathrm{H} & -2.02913 & 4.92272 & 2.21147 \\ \mathrm{O} & -3.26903 & 2.81764 & -0.06282 \\ \mathrm{H} & -4.69593 & 1.43126 & -0.28237 \\ \mathrm{H} & -0.63152 & 4.79209 & 0.38010\end{array}$




\begin{tabular}{|c|c|c|c|}
\hline $\mathrm{H}$ & -5.36863 & 1.24188 & 1.95862 \\
\hline $\mathrm{H}$ & -4.13617 & 2.44727 & 2.44099 \\
\hline $\mathrm{C}$ & -1.89285 & 3.06507 & 0.27659 \\
\hline $\mathrm{C}$ & -3.63175 & 1.44769 & -0.01212 \\
\hline $\mathrm{C}$ & -4.32014 & 1.38212 & 2.25714 \\
\hline $\mathrm{O}$ & -4.89174 & -0.56265 & -2.24965 \\
\hline $\mathrm{H}$ & -1.11372 & 2.83561 & -1.73186 \\
\hline $\mathrm{H}$ & -3.10694 & 1.00839 & -2.03505 \\
\hline $\mathrm{C}$ & -0.95446 & 2.39172 & -0.73381 \\
\hline $\mathrm{C}$ & -2.80402 & 0.66780 & -1.04052 \\
\hline $\mathrm{H}$ & -1.67776 & 2.64923 & 1.27215 \\
\hline $\mathrm{O}$ & -3.43805 & 0.86855 & 1.25287 \\
\hline $\mathrm{H}$ & -4.11940 & 0.81248 & 3.16696 \\
\hline $\mathrm{C}$ & -4.13887 & -1.24886 & -1.58705 \\
\hline $\mathrm{H}$ & -6.42830 & -2.79302 & -1.62825 \\
\hline $\mathrm{O}$ & 0.36400 & 2.58837 & -0.28804 \\
\hline $\mathrm{C}$ & -1.30446 & 0.87334 & -0.86840 \\
\hline $\mathrm{O}$ & -3.05993 & -0.75238 & -0.93501 \\
\hline $\mathrm{H}$ & -5.52683 & -3.06048 & -3.13099 \\
\hline $\mathrm{C}$ & -5.54000 & -3.26694 & -2.05695 \\
\hline $\mathrm{O}$ & -0.65004 & 0.25852 & -1.93041 \\
\hline $\mathrm{H}$ & 1.02430 & 2.31955 & -0.98696 \\
\hline $\mathrm{H}$ & -5.15996 & -2.55335 & 0.60667 \\
\hline $\mathrm{C}$ & -4.25988 & -2.76290 & -1.37812 \\
\hline $\mathrm{H}$ & -0.97547 & 0.42501 & 0.10509 \\
\hline $\mathrm{C}$ & -4.31600 & -3.06693 & 0.13339 \\
\hline $\mathrm{O}$ & 2.41320 & 1.86775 & -1.82290 \\
\hline $\mathrm{H}$ & -5.62247 & -4.34931 & -1.91347 \\
\hline $\mathrm{H}$ & -2.96861 & -3.23073 & -3.08293 \\
\hline $\mathrm{H}$ & 0.34922 & 0.15181 & -1.73383 \\
\hline $\mathrm{C}$ & -3.02827 & -3.44634 & -2.01063 \\
\hline $\mathrm{H}$ & -3.39866 & -2.75743 & 0.63911 \\
\hline $\mathrm{H}$ & -1.12185 & 0.19534 & 3.10816 \\
\hline $\mathrm{H}$ & -2.02927 & -1.07302 & 2.25811 \\
\hline $\mathrm{H}$ & -2.10018 & -3.11323 & -1.54006 \\
\hline $\mathrm{H}$ & -4.44529 & -4.14463 & 0.27940 \\
\hline $\mathrm{C}$ & -1.04818 & -0.78369 & 2.63317 \\
\hline $\mathrm{C}$ & 2.68001 & 0.67082 & -1.52070 \\
\hline $\mathrm{N}$ & -0.12498 & -0.68641 & 1.51352 \\
\hline $\mathrm{H}$ & 0.98633 & 0.89538 & 2.28595 \\
\hline $\mathrm{H}$ & -3.11326 & -4.53098 & -1.88390 \\
\hline $\mathrm{O}$ & 1.82358 & -0.26747 & -1.44497 \\
\hline $\mathrm{H}$ & 4.89696 & 2.22521 & -1.77683 \\
\hline $\mathrm{C}$ & 1.15791 & -0.10109 & 1.87772 \\
\hline $\mathrm{H}$ & -0.98919 & -2.27798 & 0.50561 \\
\hline $\mathrm{C}$ & 0.00873 & -1.92976 & 0.77168 \\
\hline
\end{tabular}




$\begin{array}{lrrr}\mathrm{H} & 1.76410 & -0.03129 & 0.97616 \\ \mathrm{H} & 0.59012 & -1.73568 & -0.13065 \\ \mathrm{C} & 5.13925 & 1.24753 & -1.37263 \\ \mathrm{C} & 4.11067 & 0.31510 & -1.18707 \\ \mathrm{C} & -0.45523 & -1.86467 & 3.61893 \\ \mathrm{H} & -0.37129 & -1.42813 & 4.61796 \\ \mathrm{H} & -1.13521 & -2.71953 & 3.67258 \\ \mathrm{C} & 1.81498 & -1.06088 & 2.94359 \\ \mathrm{H} & 1.91041 & -0.53662 & 3.89861 \\ \mathrm{C} & 0.74638 & -2.95586 & 1.71572 \\ \mathrm{C} & 0.91891 & -2.29730 & 3.09038 \\ \mathrm{C} & 6.45705 & 0.93632 & -1.04568 \\ \mathrm{C} & 4.42568 & -0.94315 & -0.65657 \\ \mathrm{H} & 7.25387 & 1.65772 & -1.19535 \\ \mathrm{H} & 0.14736 & -3.86794 & 1.78743 \\ \mathrm{H} & 3.63095 & -1.66676 & -0.50724 \\ \mathrm{H} & 2.81566 & -1.33938 & 2.60129 \\ \mathrm{H} & 1.71812 & -3.21421 & 1.28582 \\ \mathrm{C} & 6.74053 & -0.32271 & -0.51491 \\ \mathrm{H} & 1.37692 & -3.00826 & 3.78731 \\ \mathrm{C} & 5.73557 & -1.26920 & -0.31267 \\ \mathrm{H} & 5.97658 & -2.24119 & 0.10559 \\ \mathrm{Cl} & 8.39149 & -0.72200 & -0.09100\end{array}$

\section{[HAT_TS $]^{\cdot}$}

Energy (Hartree/particle): -2205.88431862

$\begin{array}{lc}\text { Zero-point correction }= & 0.618250(\text { Hartree/Particle }) \\ \text { Thermal correction to Energy= } & 0.657470 \\ \text { Thermal correction to Enthalpy= } & 0.658414 \\ \text { Thermal correction to Gibbs Free Energy }= & 0.540920 \\ \text { Sum of electronic and zero-point Energies }= & -2205.266069 \\ \text { Sum of electronic and thermal Energies }= & -2205.226849 \\ \text { Sum of electronic and thermal Enthalpies }= & -2205.225904 \\ \text { Sum of electronic and thermal Free Energies }= & -2205.343399\end{array}$

Number of imaginary frequencies: $\mathbf{1 ,}-489.9654$

\section{Geometry:}

$\begin{array}{llcc}\mathrm{C} & -3.24434 & 0.97139 & -1.49707 \\ \mathrm{C} & -2.21591 & -0.16298 & -1.48112 \\ \mathrm{C} & -0.93168 & 0.22515 & -0.76360 \\ \mathrm{O} & -0.03124 & -0.79112 & -0.82002\end{array}$




$\begin{array}{lrrr}\mathrm{C} & -0.40201 & 1.62330 & -1.17781 \\ \mathrm{C} & -1.54580 & 2.64555 & -1.29259 \\ \mathrm{C} & -1.08021 & 3.92116 & -1.98263 \\ \mathrm{O} & -2.03675 & 4.98375 & -1.91064 \\ \mathrm{O} & -2.64768 & 2.12632 & -2.06059 \\ \mathrm{O} & 0.54733 & 2.11146 & -0.26215 \\ \mathrm{O} & -2.75421 & -1.34831 & -0.85833 \\ \mathrm{O} & -3.71953 & 1.17005 & -0.18979 \\ \mathrm{H} & -1.89126 & 2.89194 & -0.27980 \\ \mathrm{H} & -4.07369 & 0.72427 & -2.17327 \\ \mathrm{H} & -1.97675 & -0.39477 & -2.52472 \\ \mathrm{H} & -1.20250 & 0.38427 & 0.45186 \\ \mathrm{H} & 0.04960 & 1.48698 & -2.17687 \\ \mathrm{C} & -4.84046 & 2.06071 & -0.11539 \\ \mathrm{C} & -3.41176 & -2.22841 & -1.65863 \\ \mathrm{H} & -0.11922 & 4.21980 & -1.54631 \\ \mathrm{H} & -0.93168 & 3.71760 & -3.04870 \\ \mathrm{H} & 1.46794 & 1.82469 & -0.56543 \\ \mathrm{H} & 0.95500 & -0.54745 & -0.55395 \\ \mathrm{H} & -2.08232 & 5.27512 & -0.98925 \\ \mathrm{O} & -3.56438 & -2.05401 & -2.85066 \\ \mathrm{C} & -3.92121 & -3.43010 & -0.85702 \\ \mathrm{C} & -4.91805 & -2.92685 & 0.20919 \\ \mathrm{C} & -2.72588 & -4.12920 & -0.17626 \\ \mathrm{C} & -4.62570 & -4.40846 & -1.80585 \\ \mathrm{H} & -1.09938 & -1.18454 & -0.15323 \\ \mathrm{H} & -1.45329 \\ \mathrm{C} & 6.44157 & -1.72956 & 0.05224 \\ \mathrm{C} & 5.09374 & -1.39149 & -0.04586 \\ \mathrm{C} & 3.23336 & 0.24721 & -0.56730 \\ \mathrm{C} & 4.69837 & -0.11401 & -0.46419 \\ \mathrm{C} & 7.40231 & -0.77166 & -0.27319 \\ \mathrm{C} & 5.68566 & 0.82701 & -0.78465 \\ \mathrm{C} & 7.03854 & 0.50846 & -0.69219 \\ \mathrm{O} & 2.93978 & 1.40133 & -0.99125 \\ \mathrm{O} & 2.39601 & -0.64179 & -0.21304 \\ \mathrm{H} & 6.74550 & -2.71995 & 0.37556 \\ \mathrm{H} & 4.33288 & -2.12399 & 0.20306 \\ \mathrm{H} & 5.38358 & 1.81770 & -1.10849 \\ \mathrm{H} & -5.80139 & 1.23937 & -0.94030 \\ \mathrm{H} & -5.66516 & 1.69425 & -0.74185 \\ \mathrm{H} & -1.31739 & 0.37103 & 5.53740 \\ \mathrm{H} & -2.41189 & 4.24398 \\ \mathrm{H} & -82764 & 3.93120\end{array}$




$\begin{array}{lrrr}\mathrm{H} & -3.43171 & 0.03231 & 4.17706 \\ \mathrm{C} & -1.30541 & 0.38400 & 4.44339 \\ \mathrm{C} & -2.48325 & -0.43342 & 3.89196 \\ \mathrm{H} & -2.47282 & -1.44898 & 4.29878 \\ \mathrm{H} & 0.86916 & 0.29184 & 4.35647 \\ \mathrm{C} & 0.00688 & -0.22387 & 3.92354 \\ \mathrm{C} & -1.51590 & 1.79975 & 2.37609 \\ \mathrm{H} & 0.07114 & -1.27910 & 4.20612 \\ \mathrm{H} & -2.50408 & 2.09101 & 2.01831 \\ \mathrm{C} & -2.36281 & -0.49167 & 2.34066 \\ \mathrm{H} & -0.76423 & 2.43481 & 1.90713 \\ \mathrm{H} & -3.27400 & -0.17009 & 1.83760 \\ \mathrm{~N} & -1.27489 & 0.41487 & 1.91714 \\ \mathrm{C} & 0.04144 & -0.07912 & 2.37306 \\ \mathrm{H} & -2.10413 & -1.49145 & 1.99001 \\ \mathrm{H} & 0.78918 & 0.63911 & 2.03636 \\ \mathrm{H} & 0.23080 & -1.03245 & 1.87642 \\ \mathrm{H} & -2.21774 & -3.46226 & 0.52394 \\ \mathrm{H} & -1.99697 & -4.47104 & -0.91898 \\ \mathrm{H} & -3.08756 & -5.00307 & 0.37599 \\ \mathrm{H} & -4.43581 & -2.25370 & 0.92100 \\ \mathrm{H} & -5.31826 & -3.78524 & 0.75911 \\ \mathrm{H} & -5.75660 & -2.39753 & -0.25640 \\ \mathrm{H} & -5.47845 & -3.93532 & -2.30165 \\ \mathrm{H} & -4.99135 & -5.26625 & -1.23202 \\ \mathrm{H} & -3.94160 & -4.77482 & -2.57711 \\ & & & \\ & & & \end{array}$

\section{[HAT_PostRC] $]^{\circ}$}

Energy (Hartree/particle): -2205.90418673

$\begin{array}{lc}\text { Zero-point correction }= & 0.624324 \text { (Hartree/Particle) } \\ \text { Thermal correction to Energy= } & 0.664124 \\ \text { Thermal correction to Enthalpy= } & 0.665069 \\ \text { Thermal correction to Gibbs Free Energy= } & 0.545269 \\ \text { Sum of electronic and zero-point Energies }= & -2205.279863 \\ \text { Sum of electronic and thermal Energies }= & -2205.240062 \\ \text { Sum of electronic and thermal Enthalpies }= & -2205.239118 \\ \text { Sum of electronic and thermal Free Energies }= & -2205.358918\end{array}$

\section{Number of imaginary frequencies: 0}

\section{Geometry:}

$\begin{array}{llll}\mathrm{C} & -3.41515 & 1.85332 & -0.80295 \\ \mathrm{C} & -2.46623 & 0.85438 & -1.49867\end{array}$




\begin{tabular}{|c|c|c|c|}
\hline $\mathrm{C}$ & -1.05784 & 0.95705 & -1.05033 \\
\hline $\mathrm{O}$ & -0.20140 & 0.20333 & -1.77862 \\
\hline $\mathrm{C}$ & -0.52462 & 2.11862 & -0.27817 \\
\hline $\mathrm{C}$ & -1.64292 & 3.00562 & 0.28946 \\
\hline $\mathrm{C}$ & -1.14599 & 4.41696 & 0.56377 \\
\hline $\mathrm{O}$ & -2.06464 & 5.21163 & 1.32064 \\
\hline $\mathrm{O}$ & -2.75169 & 3.09575 & -0.61960 \\
\hline $\mathrm{O}$ & 0.29880 & 1.70763 & 0.83804 \\
\hline $\mathrm{O}$ & -2.91036 & -0.53857 & -1.28175 \\
\hline $\mathrm{O}$ & -3.87091 & 1.28679 & 0.39835 \\
\hline $\mathrm{H}$ & -1.98128 & 2.54998 & 1.22982 \\
\hline $\mathrm{H}$ & -4.26367 & 2.08880 & -1.45609 \\
\hline $\mathrm{H}$ & -2.54136 & 1.02817 & -2.58122 \\
\hline $\mathrm{H}$ & -0.06502 & 0.21035 & 1.38517 \\
\hline $\mathrm{H}$ & 0.11585 & 2.72206 & -0.94730 \\
\hline $\mathrm{C}$ & -4.93381 & 2.02710 & 1.00828 \\
\hline $\mathrm{C}$ & -4.00327 & -0.95087 & -1.95703 \\
\hline $\mathrm{H}$ & -0.17258 & 4.34684 & 1.06825 \\
\hline $\mathrm{H}$ & -1.00507 & 4.94041 & -0.38831 \\
\hline $\mathrm{H}$ & 1.28319 & 1.71019 & 0.54707 \\
\hline $\mathrm{H}$ & 0.76150 & 0.23768 & -1.44049 \\
\hline $\mathrm{H}$ & -2.12349 & 4.82747 & 2.20676 \\
\hline $\mathrm{O}$ & -4.60622 & -0.25155 & -2.75055 \\
\hline $\mathrm{C}$ & -4.40556 & -2.37841 & -1.56021 \\
\hline $\mathrm{C}$ & -5.03616 & -2.29608 & -0.15181 \\
\hline $\mathrm{C}$ & -3.17719 & -3.30630 & -1.53261 \\
\hline $\mathrm{C}$ & -5.43986 & -2.91228 & -2.56023 \\
\hline $\mathrm{Cl}$ & 8.96716 & -0.75591 & -0.82981 \\
\hline $\mathrm{C}$ & 6.34455 & -1.07940 & -1.47887 \\
\hline $\mathrm{C}$ & 4.99549 & -0.74138 & -1.40003 \\
\hline $\mathrm{C}$ & 3.09413 & 0.67616 & -0.51467 \\
\hline $\mathrm{C}$ & 4.56268 & 0.32093 & -0.59555 \\
\hline $\mathrm{C}$ & 7.26879 & -0.34050 & -0.73965 \\
\hline $\mathrm{C}$ & 5.51384 & 1.04513 & 0.13513 \\
\hline $\mathrm{C}$ & 6.86747 & 0.72246 & 0.07001 \\
\hline $\mathrm{O}$ & 2.77573 & 1.66627 & 0.21222 \\
\hline $\mathrm{O}$ & 2.28688 & -0.04364 & -1.17333 \\
\hline $\mathrm{H}$ & 6.67733 & -1.90238 & -2.10315 \\
\hline $\mathrm{H}$ & 4.26187 & -1.30445 & -1.96770 \\
\hline $\mathrm{H}$ & 5.18354 & 1.86877 & 0.75964 \\
\hline $\mathrm{H}$ & 7.60229 & 1.28478 & 0.63713 \\
\hline $\mathrm{H}$ & -5.25281 & 1.44990 & 1.87876 \\
\hline $\mathrm{H}$ & -5.77620 & 2.13839 & 0.31097 \\
\hline $\mathrm{H}$ & -4.59602 & 3.02047 & 1.32750 \\
\hline $\mathrm{H}$ & -0.88181 & -3.92934 & 3.45732 \\
\hline $\mathrm{H}$ & -0.17378 & -1.88241 & 4.77769 \\
\hline
\end{tabular}




$\begin{array}{lccc}\mathrm{H} & 1.19327 & -2.70909 & 4.02549 \\ \mathrm{C} & 0.28565 & -2.13567 & 3.81734 \\ \mathrm{H} & -2.51381 & -2.09972 & 3.78468 \\ \mathrm{C} & -0.69262 & -2.96843 & 2.97186 \\ \mathrm{C} & -2.00866 & -2.18768 & 2.81872 \\ \mathrm{H} & -2.68173 & -2.72454 & 2.14381 \\ \mathrm{H} & 0.90564 & -3.65736 & 1.67657 \\ \mathrm{C} & -0.07991 & -3.19175 & 1.57917 \\ \mathrm{C} & 0.64710 & -0.85174 & 3.04097 \\ \mathrm{H} & -0.70699 & -3.86850 & 0.99170 \\ \mathrm{H} & 0.51084 & 0.05505 & 3.63290 \\ \mathrm{C} & -1.69688 & -0.78197 & 2.26336 \\ \mathrm{H} & 1.66945 & -0.86478 & 2.65793 \\ \mathrm{H} & -1.82809 & 0.00235 & 3.01154 \\ \mathrm{~N} & -0.25362 & -0.73125 & 1.84269 \\ \mathrm{C} & 0.03700 & -1.83248 & 0.85936 \\ \mathrm{H} & -2.29074 & -0.52213 & 1.38610 \\ \mathrm{H} & 1.03119 & -1.64126 & 0.45326 \\ \mathrm{H} & -0.68577 & -1.71383 & 0.05200 \\ \mathrm{H} & -2.44515 & -2.97884 & -0.79259 \\ \mathrm{H} & -2.68639 & -3.33969 & -2.51124 \\ \mathrm{H} & -3.49690 & -4.32178 & -1.27507 \\ \mathrm{H} & -4.32310 & -1.90557 & 0.57776 \\ \mathrm{H} & -5.34746 & -3.29758 & 0.16444 \\ \mathrm{H} & -5.91752 & -1.64590 & -0.15447 \\ \mathrm{H} & -5.74111 & -3.92259 & -2.26393 \\ \mathrm{H} & -5.02333 & -2.95966 & -3.57156 \\ \mathrm{H} & -6.33065 & -2.27893 & -2.58617\end{array}$

\section{[Piv-C2_rad-C3 $]^{\circ}$}

Energy (Hartree/particle): -996.249258477

$\begin{array}{lc}\text { Zero-point correction }= & 0.325961 \text { (Hartree/Particle) } \\ \text { Thermal correction to Energy= } & 0.347631 \\ \text { Thermal correction to Enthalpy= } & 0.348575 \\ \text { Thermal correction to Gibbs Free Energy= } & 0.274265 \\ \text { Sum of electronic and zero-point Energies }= & -995.923298 \\ \text { Sum of electronic and thermal Energies }= & -995.901628 \\ \text { Sum of electronic and thermal Enthalpies }= & -995.900684 \\ \text { Sum of electronic and thermal Free Energies }= & -995.974994\end{array}$

Number of imaginary frequencies: 0 


\section{Geometry:}

$\begin{array}{lrrr}\mathrm{C} & -0.50208 & 1.11973 & 0.47570 \\ \mathrm{C} & 0.04165 & -0.32213 & 0.58550 \\ \mathrm{C} & -0.88395 & -1.29132 & -0.05167 \\ \mathrm{O} & -0.42728 & -2.58401 & -0.11726 \\ \mathrm{C} & -2.35162 & -1.10926 & 0.13456 \\ \mathrm{C} & -2.74073 & 0.37436 & 0.06051 \\ \mathrm{C} & -4.15204 & 0.63784 & 0.58674 \\ \mathrm{O} & -5.14296 & -0.12840 & -0.11838 \\ \mathrm{O} & -1.86473 & 1.15358 & 0.89319 \\ \mathrm{O} & -3.01813 & -1.90084 & -0.86453 \\ \mathrm{O} & 1.34335 & -0.44109 & -0.05320 \\ \mathrm{O} & -0.31799 & 1.56718 & -0.83782 \\ \mathrm{H} & -2.65986 & 0.70183 & -0.98501 \\ \mathrm{H} & 0.01565 & 1.77579 & 1.18597 \\ \mathrm{H} & 0.18222 & -0.53509 & 1.65689 \\ \mathrm{H} & -2.64197 & -1.48691 & 1.13816 \\ \mathrm{C} & -0.53557 & 2.97548 & -0.99441 \\ \mathrm{C} & 2.42147 & -0.00651 & 0.64228 \\ \mathrm{H} & -4.21305 & 0.32281 & 1.63362 \\ \mathrm{H} & -4.36995 & 1.71179 & 0.53308 \\ \mathrm{H} & -3.96973 & -1.76749 & -0.70826 \\ \mathrm{H} & -1.16448 & -3.12544 & -0.44883 \\ \mathrm{H} & -5.27770 & 0.28314 & -0.98414 \\ \mathrm{O} & 2.35047 & 0.46257 & 1.76181 \\ \mathrm{C} & 3.70800 & -0.17329 & -0.17539 \\ \mathrm{C} & 4.90883 & 0.26123 & 0.67449 \\ \mathrm{C} & 3.60451 & 0.71937 & -1.43172 \\ \mathrm{C} & 3.86581 & -1.65034 & -0.59150 \\ \mathrm{H} & -0.28868 & 3.21356 & -2.03097 \\ \mathrm{H} & 0.11897 & 3.54440 & -0.31941 \\ \mathrm{H} & -1.58050 & 3.24150 & -0.79453 \\ \mathrm{H} & 4.80078 & -1.76873 & -1.14984 \\ \mathrm{H} & 3.03847 & -1.97614 & -1.22660 \\ \mathrm{H} & 3.90844 & -2.30321 & 0.28734 \\ & 5.82625 & 0.14641 & 0.08785 \\ \mathrm{H} & 4.99790 & -0.35054 & 1.57747 \\ \mathrm{H} & 4.82212 & 1.30855 & 0.97845 \\ \mathrm{H} & 2.763177 & 1.77028 & -1.15609 \\ \mathrm{H} & 0.41214 & -2.06894\end{array}$

[quin- $\left.\mathrm{H}_{-}^{+} \mathrm{ArCO}_{2}^{-}\right]$

Energy (Hartree/particle): -1209.62337854 
Zero-point correction $=$

Thermal correction to Energy=

Thermal correction to Enthalpy=

Thermal correction to Gibbs Free Energy=

Sum of electronic and zero-point Energies $=$

Sum of electronic and thermal Energies=

Sum of electronic and thermal Enthalpies=

Sum of electronic and thermal Free Energies=
0.296219 (Hartree/Particle)

0.313092

0.314036

0.247790

$-1209.327160$

$-1209.310287$

$-1209.309343$

$-1209.375589$

\section{Number of imaginary frequencies: 0}

\section{Geometry:}

$\begin{array}{lrrr}\mathrm{C} & 0.37501 & 1.05914 & 0.37820 \\ \mathrm{C} & 0.86264 & -0.40625 & 0.42248 \\ \mathrm{C} & -0.14623 & -1.32308 & -0.16385 \\ \mathrm{O} & 0.24721 & -2.63246 & -0.28332 \\ \mathrm{C} & -1.58836 & -1.08281 & 0.12704 \\ \mathrm{C} & -1.91671 & 0.41692 & 0.10531 \\ \mathrm{C} & -3.27717 & 0.72979 & 0.72907 \\ \mathrm{O} & -4.34503 & 0.02590 & 0.07307 \\ \mathrm{O} & -0.95288 & 1.13974 & 0.89040 \\ \mathrm{O} & -2.35505 & -1.82671 & -0.83622 \\ \mathrm{O} & 2.11311 & -0.56686 & -0.30922 \\ \mathrm{O} & 0.48726 & 1.52792 & -0.93606 \\ \mathrm{H} & -1.89213 & 0.76231 & -0.93733 \\ \mathrm{H} & 0.96760 & 1.67754 & 1.06365 \\ \mathrm{H} & 1.07012 & -0.64714 & 1.47681 \\ \mathrm{H} & -1.82532 & -1.46713 & 1.14206 \\ \mathrm{C} & 0.30005 & 2.94492 & -1.05097 \\ \mathrm{C} & 3.25455 & -0.21239 & 0.33026 \\ \mathrm{H} & -3.28588 & 0.39225 & 1.77061 \\ \mathrm{H} & -3.44839 & 1.81343 & 0.71253 \\ \mathrm{H} & -3.28719 & -1.65767 & -0.61225 \\ \mathrm{H} & -0.53472 & -3.13463 & -0.57151 \\ \mathrm{H} & -4.50772 & 0.45783 & -0.77793 \\ \mathrm{O} & 3.29036 & 0.22964 & 1.46228 \\ \mathrm{C} & 4.44938 & -0.43276 & -0.56063 \\ \mathrm{H} & 5.36613 & -0.23865 & -0.00353 \\ \mathrm{H} & 4.39081 & 0.24458 & -1.41955 \\ \mathrm{H} & 4.45110 & -1.45575 & -0.94846 \\ \mathrm{H} & 0.48862 & 3.19835 & -2.09609 \\ \mathrm{H} & 1.01059 & 3.48171 & -0.40698 \\ \mathrm{H} & -0.72247 & 3.23461 & -0.78083\end{array}$




\section{[1,2-mig_TS1 $]^{\circ}$}

Energy (Hartree/particle): -996.204949728

$\begin{array}{lc}\text { Zero-point correction }= & 0.324818 \text { (Hartree/Particle) } \\ \text { Thermal correction to Energy= } & 0.345381 \\ \text { Thermal correction to Enthalpy= } & 0.346325 \\ \text { Thermal correction to Gibbs Free Energy }= & 0.276110 \\ \text { Sum of electronic and zero-point Energies }= & -995.880132 \\ \text { Sum of electronic and thermal Energies }= & -995.859569 \\ \text { Sum of electronic and thermal Enthalpies }= & -995.858624 \\ \text { Sum of electronic and thermal Free Energies }= & -995.928840\end{array}$

Number of imaginary frequencies: $1,-668.1175$

\section{Geometry:}

$\begin{array}{lrrr}\mathrm{C} & -0.94984 & 1.62000 & 0.86075 \\ \mathrm{C} & 0.10241 & 0.56034 & 1.31549 \\ \mathrm{C} & -0.17725 & -0.83922 & 0.83150 \\ \mathrm{O} & 0.49930 & -1.77893 & 1.55793 \\ \mathrm{C} & -1.57705 & -1.22883 & 0.44606 \\ \mathrm{C} & -2.33400 & -0.04474 & -0.15703 \\ \mathrm{C} & -3.82687 & -0.32525 & -0.33445 \\ \mathrm{O} & -4.07018 & -1.46206 & -1.18092 \\ \mathrm{O} & -2.25127 & 1.04463 & 0.77838 \\ \mathrm{O} & -1.51294 & -2.38000 & -0.39888 \\ \mathrm{O} & 1.43347 & 0.90813 & 0.86377 \\ \mathrm{O} & -0.54615 & 2.21005 & -0.33931 \\ \mathrm{H} & -1.88149 & 0.23683 & -1.11619 \\ \mathrm{H} & -2.09399 & -1.48995 & 1.38952 \\ \mathrm{C} & -1.31429 & 3.36909 & -0.68437 \\ \mathrm{C} & 1.72847 & 0.18481 & -0.28138 \\ \mathrm{H} & -4.26811 & -0.57219 & 0.63680 \\ \mathrm{H} & -4.32341 & 0.57167 & -0.72471 \\ \mathrm{H} & -2.42771 & -2.52947 & -0.70248 \\ \mathrm{H} & -3.88426 & -1.20038 & -2.09427 \\ \mathrm{O} & 0.72909 & -0.53917 & -0.69818 \\ \mathrm{C} & 3.19385 & -0.19650 & -0.45445 \\ \mathrm{C} & 3.38391 & -0.78068 & -1.86406 \\ \mathrm{C} & 3.61355 & -1.24627 & 0.59998 \\ \mathrm{C} & 4.06495 & 1.06394 & -0.29798 \\ \mathrm{H} & 0.24382 & -2.65425 & 1.22202 \\ \mathrm{H} & -0.85338 & 3.78938 & -1.58058 \\ \mathrm{H} & -1.28437 & 4.10984 & 0.12765 \\ \mathrm{H} & -2.35813 & 3.10790 & -0.89546\end{array}$




$\begin{array}{rrrr}\mathrm{H} & -1.05475 & 2.38507 & 1.64279 \\ \mathrm{H} & 0.14827 & 0.57330 & 2.40730 \\ \mathrm{H} & 2.77590 & -1.67976 & -2.00257 \\ \mathrm{H} & 4.43580 & -1.04764 & -2.01557 \\ \mathrm{H} & 3.09856 & -0.05191 & -2.63125 \\ \mathrm{H} & 3.97063 & 1.48914 & 0.70570 \\ \mathrm{H} & 3.77514 & 1.83084 & -1.02540 \\ \mathrm{H} & 5.11766 & 0.80987 & -0.46573 \\ \mathrm{H} & 3.46184 & -0.86217 & 1.61337 \\ \mathrm{H} & 4.67565 & -1.49372 & 0.47834 \\ \mathrm{H} & 3.02873 & -2.16378 & 0.48818\end{array}$

\section{[1,2-mig_int $]^{\circ}$}

Energy (Hartree/particle): -996.217482496

\begin{tabular}{|c|c|c|c|}
\hline \multicolumn{4}{|c|}{ Zero-point correction $=$} \\
\hline \multicolumn{4}{|c|}{ Thermal correction to Energy= } \\
\hline \multicolumn{4}{|c|}{ Thermal correction to Enthalpy= } \\
\hline \multicolumn{4}{|c|}{ Thermal correction to Gibbs Free Energy= } \\
\hline \multicolumn{4}{|c|}{ Sum of electronic and zero-point Energies $=$} \\
\hline \multirow{3}{*}{\multicolumn{4}{|c|}{$\begin{array}{l}\text { Sum of electronic and thermal Energies }= \\
\text { Sum of electronic and thermal Enthalpies }= \\
\text { Sum of electronic and thermal Free Energie }\end{array}$}} \\
\hline & & & \\
\hline & & & \\
\hline \multicolumn{4}{|c|}{ Number of imaginary frequencies: 0} \\
\hline \multicolumn{4}{|c|}{ Geometry: } \\
\hline $\mathrm{C}$ & -0.66232 & 1.50684 & 1.09300 \\
\hline $\mathrm{C}$ & 0.09869 & 0.24309 & 1.59090 \\
\hline $\mathrm{C}$ & -0.28447 & -1.06608 & 0.87426 \\
\hline $\mathrm{O}$ & -0.04597 & -2.13568 & 1.77140 \\
\hline $\mathrm{C}$ & -1.71561 & -1.13198 & 0.33747 \\
\hline $\mathrm{C}$ & -2.16975 & 0.21181 & -0.23237 \\
\hline $\mathrm{C}$ & -3.65278 & 0.22303 & -0.60724 \\
\hline $\mathrm{O}$ & -3.96374 & -0.75870 & -1.61226 \\
\hline $\mathrm{O}$ & -2.02438 & 1.19500 & 0.80729 \\
\hline $\mathrm{O}$ & -1.79442 & -2.21223 & -0.58627 \\
\hline $\mathrm{O}$ & 1.50998 & 0.34143 & 1.34697 \\
\hline $\mathrm{O}$ & 0.00159 & 2.04842 & -0.00707 \\
\hline $\mathrm{H}$ & -1.55931 & 0.48077 & -1.10481 \\
\hline $\mathrm{H}$ & -2.34956 & -1.32859 & 1.21826 \\
\hline $\mathrm{C}$ & -0.48943 & 3.33544 & -0.39736 \\
\hline $\mathrm{C}$ & 1.84094 & -0.55926 & 0.33189 \\
\hline
\end{tabular}




$\begin{array}{rrrr}\mathrm{H} & -4.25385 & -0.04107 & 0.26896 \\ \mathrm{H} & -3.93873 & 1.22942 & -0.93628 \\ \mathrm{H} & -2.64511 & -2.09909 & -1.05134 \\ \mathrm{H} & -3.62359 & -0.43808 & -2.46012 \\ \mathrm{O} & 0.66965 & -1.09085 & -0.19782 \\ \mathrm{C} & 2.94618 & -0.20939 & -0.63426 \\ \mathrm{C} & 3.31842 & -1.48627 & -1.41420 \\ \mathrm{C} & 4.16681 & 0.27113 & 0.17256 \\ \mathrm{C} & 2.52239 & 0.89444 & -1.63257 \\ \mathrm{H} & -0.31109 & -2.94977 & 1.31476 \\ \mathrm{H} & 0.16920 & 3.68636 & -1.19452 \\ \mathrm{H} & -0.45197 & 4.03689 & 0.44820 \\ \mathrm{H} & -1.51875 & 3.27473 & -0.77019 \\ \mathrm{H} & -0.72760 & 2.24385 & 1.90604 \\ \mathrm{H} & -0.06534 & 0.14711 & 2.66660 \\ \mathrm{H} & 3.62049 & -2.28705 & -0.73001 \\ \mathrm{H} & 4.15356 & -1.27431 & -2.09096 \\ \mathrm{H} & 2.47471 & -1.84430 & -2.01239 \\ \mathrm{H} & 2.27815 & 1.81980 & -1.10686 \\ \mathrm{H} & 1.64320 & 0.58417 & -2.20561 \\ \mathrm{H} & 3.34226 & 1.09029 & -2.33411 \\ \mathrm{H} & 3.93907 & 1.18652 & 0.72718 \\ \mathrm{H} & 4.99786 & 0.48077 & -0.50974 \\ \mathrm{H} & 4.49039 & -0.49447 & 0.88660\end{array}$

\section{[1,2-mig_TS2 $]^{\circ}$}

Energy (Hartree/particle): -996.201092601

$\begin{array}{lc}\text { Zero-point correction }= & 0.324401 \text { (Hartree/Particle) } \\ \text { Thermal correction to Energy= } & 0.344902 \\ \text { Thermal correction to Enthalpy= } & 0.345846 \\ \text { Thermal correction to Gibbs Free Energy= } & 0.276299 \\ \text { Sum of electronic and zero-point Energies }= & -995.876692 \\ \text { Sum of electronic and thermal Energies }= & -995.856191 \\ \text { Sum of electronic and thermal Enthalpies }= & -995.855247 \\ \text { Sum of electronic and thermal Free Energies }= & -995.924794\end{array}$

Number of imaginary frequencies: $1,-786.4869$

\begin{tabular}{lrrr}
\multicolumn{4}{l}{ Geometry: } \\
$\mathrm{C}$ & 0.52509 & 1.44539 & -1.28392 \\
$\mathrm{C}$ & 0.01317 & 0.10049 & -1.77960 \\
$\mathrm{C}$ & 0.41898 & -1.14146 & -1.01882 \\
$\mathrm{O}$ & 0.38429 & -2.24453 & -1.89409
\end{tabular}




$\begin{array}{lrrr}\mathrm{C} & 1.78710 & -1.02506 & -0.33407 \\ \mathrm{C} & 1.96726 & 0.35791 & 0.29871 \\ \mathrm{C} & 3.36278 & 0.55939 & 0.89456 \\ \mathrm{O} & 3.64914 & -0.38444 & 1.94246 \\ \mathrm{O} & 1.85235 & 1.33571 & -0.74657 \\ \mathrm{O} & 1.92910 & -2.10785 & 0.57836 \\ \mathrm{O} & -1.67454 & -0.12158 & -1.51550 \\ \mathrm{O} & -0.36581 & 1.98688 & -0.34393 \\ \mathrm{H} & 1.20291 & 0.52419 & 1.07009 \\ \mathrm{H} & 2.53392 & -1.10365 & -1.14191 \\ \mathrm{C} & -0.05155 & 3.33010 & 0.03776 \\ \mathrm{C} & -1.74209 & -0.66187 & -0.33168 \\ \mathrm{H} & 4.11864 & 0.38995 & 0.12092 \\ \mathrm{H} & 3.45846 & 1.59046 & 1.25574 \\ \mathrm{H} & 2.66801 & -1.86465 & 1.16871 \\ \mathrm{H} & 3.13608 & -0.13118 & 2.72359 \\ \mathrm{O} & -0.60180 & -1.32996 & 0.02064 \\ \mathrm{C} & -2.66924 & -0.24112 & 0.79836 \\ \mathrm{C} & -1.87677 & 0.26703 & 2.02395 \\ \mathrm{C} & -3.49093 & -1.48315 & 1.21965 \\ \mathrm{C} & -3.61946 & 0.85571 & 0.29661 \\ \mathrm{H} & 0.72715 & -3.00664 & -1.40091 \\ \mathrm{H} & -0.87541 & 3.67042 & 0.66870 \\ \mathrm{H} & 0.02513 & 3.97680 & -0.84807 \\ \mathrm{H} & 0.88774 & 3.37729 & 0.60090 \\ \mathrm{H} & 0.64773 & 2.13572 & -2.12968 \\ \mathrm{H} & 0.07762 & -0.00502 & -2.85677 \\ \mathrm{H} & -3.06242 & 1.75192 & 0.01176 \\ \mathrm{H} & -4.32419 & 1.11641 & 1.09366 \\ \mathrm{H} & -4.19409 & 0.51568 & -0.57132 \\ \mathrm{H} & -4.08874 & -1.85728 & 0.38123 \\ \mathrm{H} & -4.16870 & -1.22052 & 2.04053 \\ \mathrm{H} & -2.83324 & -2.28926 & 1.56173 \\ \mathrm{H} & -1.27640 & 1.14033 & 1.76173 \\ \mathrm{H} & -1.21066 & -0.51016 & 2.40932 \\ \mathrm{H} & -2.57729 & 0.54524 & 2.82007\end{array}$

[Piv-C3_rad-C2 $]^{\circ}$

Energy (Hartree/particle): -996.246654150

Zero-point correction $=$

Thermal correction to Energy=

Thermal correction to Enthalpy=
0.324191 (Hartree/Particle)

0.345911

0.346855 
Thermal correction to Gibbs Free Energy=

Sum of electronic and zero-point Energies=

Sum of electronic and thermal Energies=

Sum of electronic and thermal Enthalpies=

Sum of electronic and thermal Free Energies=
0.273535

$-995.922464$

$-995.900743$

$-995.899799$

$-995.973119$

\section{Number of imaginary frequencies: 0}

$\begin{array}{lrrr}\text { Geometry: } & & \\ \mathrm{C} & -1.14392 & 1.80198 & 0.88851 \\ \mathrm{C} & -0.51519 & 0.81147 & 1.80505 \\ \mathrm{C} & -0.33684 & -0.58034 & 1.33691 \\ \mathrm{O} & 0.01385 & -1.42518 & 2.39296 \\ \mathrm{C} & -1.63105 & -1.04670 & 0.63841 \\ \mathrm{C} & -2.07109 & -0.01047 & -0.40901 \\ \mathrm{C} & -3.40218 & -0.37752 & -1.07087 \\ \mathrm{O} & -3.32495 & -1.62613 & -1.78327 \\ \mathrm{O} & -2.30371 & 1.24549 & 0.24435 \\ \mathrm{O} & -1.42633 & -2.34989 & 0.11224 \\ \mathrm{O} & 2.22269 & 0.49890 & 1.46840 \\ \mathrm{O} & -0.18658 & 2.24889 & -0.05455 \\ \mathrm{H} & -1.29048 & 0.09359 & -1.17491 \\ \mathrm{H} & -2.40309 & -1.06412 & 1.42596 \\ \mathrm{C} & -0.63425 & 3.35985 & -0.84181 \\ \mathrm{C} & 1.90502 & -0.10350 & 0.46217 \\ \mathrm{H} & -4.17030 & -0.51415 & -0.30303 \\ \mathrm{H} & -3.71425 & 0.43636 & -1.73624 \\ \mathrm{H} & -2.11056 & -2.47855 & -0.57383 \\ \mathrm{H} & -2.81807 & -1.47795 & -2.59480 \\ \mathrm{O} & 0.69878 & -0.67610 & 0.26561 \\ \mathrm{C} & 2.82365 & -0.34122 & -0.74823 \\ \mathrm{C} & 2.12530 & 0.14410 & -2.03370 \\ \mathrm{C} & 3.11009 & -1.85551 & -0.84597 \\ \mathrm{C} & 4.13640 & 0.42640 & -0.54656 \\ \mathrm{H} & -0.10563 & -2.33565 & 2.07710 \\ \mathrm{H} & 0.21404 & 3.66267 & -1.45955 \\ \mathrm{H} & -0.93677 & 4.19762 & -0.19700 \\ \mathrm{H} & -1.47574 & 3.07803 & -1.48575 \\ \mathrm{H} & -1.54660 & 2.65925 & 1.44543 \\ \mathrm{H} & -0.23796 & 1.08723 & 2.81290 \\ \mathrm{H} & 1.86677 & 1.20537 & -1.96236 \\ \mathrm{H} & 1.21019 & -0.42124 & -2.22610 \\ \mathrm{H} & 2.80295 & 0.00960 & -2.88403 \\ \mathrm{H} & 3.58266 & -2.22629 & 0.07042 \\ \mathrm{H} & 3.79362 & -2.04113 & -1.68179 \\ & 2.18991 & -2.42055 & -1.01696\end{array}$




$\begin{array}{llll}\mathrm{H} & 3.95512 & 1.50237 & -0.46151 \\ \mathrm{H} & 4.79237 & 0.25341 & -1.40632 \\ \mathrm{H} & 4.65603 & 0.09511 & 0.35714\end{array}$

\section{[C3-keto C2-rad] ${ }^{*}$}

Energy (Hartree/particle): -649.290357350

$\begin{array}{lc}\text { Zero-point correction }= & 0.178895 \text { (Hartree/Particle) } \\ \text { Thermal correction to Energy= } & 0.191337 \\ \text { Thermal correction to Enthalpy= } & 0.192282 \\ \text { Thermal correction to Gibbs Free Energy= } & 0.139371 \\ \text { Sum of electronic and zero-point Energies }= & -649.111462 \\ \text { Sum of electronic and thermal Energies }= & -649.099020 \\ \text { Sum of electronic and thermal Enthalpies }= & -649.098076 \\ \text { Sum of electronic and thermal Free Energies }= & -649.150986\end{array}$

\section{Number of imaginary frequencies: 0}

\section{Geometry:}

$\begin{array}{lrrr}\mathrm{C} & -1.66657 & 0.22789 & 0.51461 \\ \mathrm{C} & -1.09400 & 1.59286 & 0.31609 \\ \mathrm{C} & 0.30320 & 1.82577 & 0.09007 \\ \mathrm{O} & 0.72920 & 2.94187 & -0.24458 \\ \mathrm{C} & 1.23946 & 0.62881 & 0.27248 \\ \mathrm{C} & 0.48380 & -0.69657 & 0.04191 \\ \mathrm{C} & 1.30653 & -1.92609 & 0.43500 \\ \mathrm{O} & 2.53813 & -2.01358 & -0.30184 \\ \mathrm{O} & -0.67287 & -0.71546 & 0.89182 \\ \mathrm{O} & 2.36636 & 0.77331 & -0.57256 \\ \mathrm{O} & -2.33486 & -0.12412 & -0.68034 \\ \mathrm{H} & 0.18523 & -0.76835 & -1.01373 \\ \mathrm{H} & 1.53752 & 0.63979 & 1.33958 \\ \mathrm{C} & -3.19731 & -1.26535 & -0.53494 \\ \mathrm{H} & 1.58785 & -1.85115 & 1.49051 \\ \mathrm{H} & 0.69951 & -2.82930 & 0.29812 \\ \mathrm{H} & 2.81445 & -0.09448 & -0.55336 \\ \mathrm{H} & 2.33302 & -2.32768 & -1.19430 \\ \mathrm{H} & -3.68734 & -1.40509 & -1.50044 \\ \mathrm{H} & -3.95409 & -1.08204 & 0.24017 \\ \mathrm{H} & -2.62211 & -2.16271 & -0.27952 \\ \mathrm{H} & -2.37695 & 0.22361 & 1.35704 \\ \mathrm{H} & -1.77537 & 2.43734 & 0.26464\end{array}$

\section{[PivOH]}


Energy (Hartree/particle): -346.967917559

Zero-point correction $=$

Thermal correction to Energy=

Thermal correction to Enthalpy=

Thermal correction to Gibbs Free Energy=

Sum of electronic and zero-point Energies=

Sum of electronic and thermal Energies=

Sum of electronic and thermal Enthalpies=

Sum of electronic and thermal Free Energies=
0.143058 (Hartree/Particle)

0.151479

0.152424

0.110516

$-346.824860$

$-346.816438$

$-346.815494$

$-346.857402$

\section{Number of imaginary frequencies: 0}

\section{Geometry:}

$\begin{array}{lrrr}\mathrm{C} & -0.94719 & 0.18811 & -0.00003 \\ \mathrm{C} & 0.56957 & -0.01215 & -0.00000 \\ \mathrm{C} & 0.97057 & -0.80393 & 1.26345 \\ \mathrm{C} & 1.26245 & 1.35633 & -0.00022 \\ \mathrm{C} & 0.97061 & -0.80436 & -1.26319 \\ \mathrm{O} & -1.52580 & 1.25692 & -0.00003 \\ \mathrm{O} & -1.62433 & -0.99099 & -0.00001 \\ \mathrm{H} & -2.57403 & -0.77455 & 0.00002 \\ \mathrm{H} & 0.66997 & -0.27216 & 2.17275 \\ \mathrm{H} & 2.05937 & -0.92156 & 1.28117 \\ \mathrm{H} & 0.51476 & -1.79733 & 1.27323 \\ \mathrm{H} & 0.99149 & 1.93786 & 0.88600 \\ \mathrm{H} & 0.99152 & 1.93758 & -0.88663 \\ \mathrm{H} & 2.34770 & 1.21138 & -0.00017 \\ \mathrm{H} & 0.51477 & -1.79775 & -1.27264 \\ \mathrm{H} & 2.05940 & -0.92202 & -1.28082 \\ \mathrm{H} & 0.67005 & -0.27288 & -2.17267\end{array}$




\section{$\underline{\text { References }}$}

1. Wang, Y.; Carder, H. M.; Wendlandt, A. E. Synthesis of rare sugar isomers through siteselective epimerization. Nature. 2020, 578, 403-408.

2. Nagae, H.; Aoki, R.; Akutagawa, S.; Kleemann, J.; Tagawa, R.; Schindler, T.; Choi, G.; Spaniol, T. P.; Tsurugi, H.; Okuda, J.; Mashima, K. Lanthanide complexes supported by a trizinc crown ether as catalysts for alternating copolymerization of epoxide and $\mathrm{CO} 2$ : telomerization controlled by carboxylate anions. Angew. Chem. Int. Ed. 2018, 57, 24922496.

3. Chen, K.; Schwarz, J.; Karl, T. A.; Chatterjee, A.; König, B. Visible light induced redox neutral fragmentation of 1,2-diol derivatives. Chem. Comm. 2019, 55, 13144-13147.

4. Zhu, Q.; Graff, D. E.; Knowles, R. R. Intermolecular anti-markovnikov hydroamination of unactivated alkenes with sulfonamides enabled by proton-coupled electron transfer. $J$. Am. Chem. Soc. 2018, 140, 741-747.

5. Mancini, R. S.; Lee, J. B.; Taylor, M. S. Boronic esters as protective groups in carbohydrate chemistry: processes for acylation, silylatin and alkylation of glycosidederived boronates. Org. Biomol. Chem. 2017, 15, 132-143.

6. Evtushenko, E. V. Regioselective benzoylation of glycopyranosides by benzoic anhydride in the presence of $\mathrm{Cu}\left(\mathrm{CF}_{3} \mathrm{COO}\right)_{2}$. Carbohydr. Res. 2012, 359, 111-119.

7. Demizu, Y.; Kubo, Y.; Miyoshi, H.; Maki, T.; Matsumura, Y.; Moriyama, N.; Onomura, O. Regioselective protection of sugars catalyzed by dimethyltin dichloride. Org. Lett. 2008, 10, 5075-5077.

8. Muramatsu, W. Chemo- and regioselective monosulfonylation of nonprotected carbohydrates catalyzed by organotin dichloride under mild conditions. J. Org. Chem. 2012, 77, 8083-8091

9. Lee, D.; Taylor, M. S. Borinic acid-catalyzed regioselective acylation for carbohydrate derivatives. J. Am. Chem. Soc. 2011, 133, 11, 3724-3727.

10. Chen, I.H.; Kou, K.G.M.; Le, D.N.; Rathbun, C.M.; Dong, V.M. Recognition and siteselective transformation of monosaccharides by using copper (II) catalysis. Chem. Eur. J. 2014, 20, 5013.

11. Jiang, L.; Chan, T.K. Regioselective acylation of hexopyranosides with pivaloyl chloride. J. Org. Chem. 1998, 63, 6035-6038.

12. Mancini, R. S.; Lee, J. B.; Taylor, M. S. Sequential functionalization of carbohydrates enabled by boronic esters as switchable protective/activating groups. J. Org. Chem. 2017, $82,17,8777-8791$.

13. Shimada, N.; Nakamura, Y.; Ochiai, T.; Makino, K. Catalytic activation of cis-vicinal diols by boronic acids: site-selective acylation of carbohydrates. Org. Lett., 2019, 21, 3789-3794.

14. Komarova, B. S.; Tsvetkov, Y. E.; Knirel, Y. A.; Zahringer, U.; Pier, G. B.; Nifantiev, N. E. Synthesis of a common trisaccharide fragment of glycoforms of the outer core region of the Pseudomonas aeruginosa lipopolysaccharide. Tetrahedron Lett. 2006, 47, 35833587.

15. Cheshev, P.; Marra, A.; Dondoni, A. Direct epoxidation of D-glucal and D-galactal derivatives with in situ generated DMDO. Carbohydr. Res. 2006, 34, 2714-2716. 
16. Seeberger, P. H.; Eckhardt, M.; Gutteridge, C. E.; Danishefsky, S. J. Coupling of glycal derived thioethyl glycosyl donors with glycal acceptors. An advance in the scope of the glycal assembly. J. Am. Chem. Soc. 1997, 119, 10064-10072.

17. Kazunobu, T.; Takehito, Y.; Satsuki, M.; Kuniaki. T. De novo highly stereocontrolled synthesis of 2,6-dideoxy sugars by use of 2,6-anhydro-2-thio sugars. Carbohydr. Res., 1991, 222, 173-188.

18. Evans, D. A.; Hoveyda, A. H. Reduction of $\beta$-hydroxy ketones with catecholborane. A stereoselective approach to the synthesis of syn 1,3-diols. J. Org. Chem. 1990, 55, 18, 5190-5192.

19. Horton, D.; Priebe, W.; and Sznaidman, M. L. Steric and conformational effects in the dehalogenation of 2-halo sugar derivatives with tributylstannane. J. Org. Chem. 1993, 58, 1821-1826

20. Marinus, N.; Tahiri, N.; Duca, M.; Mouthaan, L.M.C.M.; Bianca, S.; van den Noort, M.; Poolman, B.; Witte, M.D.; Minnaard, A.J. Stereoselective protection-free modification of 3-keto-saccharides. Org. Lett., 2020, 22, 5622-5626.

21. Leet, J.E.; Schroeder, D.R.; Langley, D.R.; Colson, K.L.; Huang, S.; Klohr, S.E.; Lee, M.S.; Golik, J.; Hofstead, S.J.; Doyle, T.W.; Matson, J.A. Chemistry and structure elucidation of the kedarcidin chromophore. J. Am. Chem. Soc. 1993, 115, 8432-8443.

22. Liu, N.; Tian, X.; Ding, Z.; Zhou, Y.; Zhang, W.; Wang, Q.; Zhang, Y.; Gu, Y.; Zhang, J. Synthesis of aryl $\alpha$-O-L-rhamnopyranoside by two-step reaction in one pot. J. Carbohydr. Chem., 2017, 36, 220-234.

23. Groneberg, R.D.; Miyazaki, T.; Stylianides, N.A.; Schulze, T.J.; Stahl, W.; Schreiner, E.P.; Suzuki, T.; Iwabuchi, Y.; Smith, A.L.; Nicolaou, K.C. Total synthesis of calicheamicin .gamma. 1I. 1. Synthesis of the oligosaccharide fragment. J. Am. Chem. Soc., 1993, 115, 7593-7611.

24. Pozsgay, V. A simple method for avoiding alkylthio group migration during the synthesis of thioglycoside 2,3-orthoesters. An improved synthesis of partially acylated 1-thio- $\alpha$-Lrhamopyranosides. Carbohydr. Res., 1992, 235, 295-302.

25. Thadke, S. A.; Mishra, B.; Hotha, S. Gold(III)-catalyzed glycosidations of 1,2-trans and 1,2-cis furanosides. J. Org. Chem. 2014, 79, 16, 7258-7371.

26. Gaussian 16, Revision B.01, M. J. Frisch, G. W. Trucks, H. B. Schlegel, G. E. Scuseria, M. A. Robb, J. R. Cheeseman, G. Scalmani, V. Barone, G. A. Petersson, H. Nakatsuji, X. Li, M. Caricato, A. V. Marenich, J. Bloino, B. G. Janesko, R. Gomperts, B. Mennucci, H. P. Hratchian, J. V. Ortiz, A. F. Izmaylov, J. L. Sonnenberg, D. Williams-Young, F. Ding, F. Lipparini, F. Egidi, J. Goings, B. Peng, A. Petrone, T. Henderson, D. Ranasinghe, V. G. Zakrzewski, J. Gao, N. Rega, G. Zheng, W. Liang, M. Hada, M. Ehara, K. Toyota, R. Fukuda, J. Hasegawa, M. Ishida, T. Nakajima, Y. Honda, O. Kitao, H. Nakai, T. Vreven, K. Throssell, J. A. Montgomery Jr., J. E. Peralta, F. Ogliaro, M. J. Bearpark, J. J. Heyd, E. N. Brothers, K. N. Kudin, V. N. Staroverov, T. A. Keith, R. Kobayashi, J. Normand, K. Raghavachari, A. P. Rendell, J. C. Burant, S. S. Iyengar, J. Tomasi, M. Cossi, J. M. Millam, M. Klene, C. Adamo, R. Cammi, J. W. Ochterski, R. L. Martin, K. Morokuma, O. Farkas, J. B. Foresman, D. J. Fox, Gaussian, Inc., Wallingford CT, 2016.

27. Grimme, S.; Ehrlich, S.; Goerigk, L. Effect of the damping function in dispersion corrected density functional theory. J. Comput. Chem. 2011, 32, 1456-1465. 
28. Weigend, F.; Ahlrichs, R. Balanced basis sets of split valence, triple zeta valence and quadruple zeta valence quality for H to Rn: Design and assessment of accuracy. Phys. Chem. Chem. Phys. 2005, 7, 3297-3305.

29. Vydrov, O. A.; Van Voorhis, T. Nonlocal van der Waals density functional: the simpler the better. J. Chem. Phys. 2010, 133, 244103.

30. Hujo, W.; Grimme, S. Performance of the van der Waals density functional VV10 and (hybrid)GGA variants for thermochemistry and noncovalent interactions. J. Chem. Theory Comput. 2011, 7, 3866. 


\section{$\underline{{ }^{1} \mathrm{H},{ }^{13} \mathrm{C} \text { and 2D NMR Spectra }}$}

This page intentionally left blank. 
Tetrabutylammonium 2,3,4,5-tetrafluorobenzoate

${ }^{1} \mathrm{H}$ NMR (400 MHz, $\left.\mathrm{CDCl}_{3}\right)$

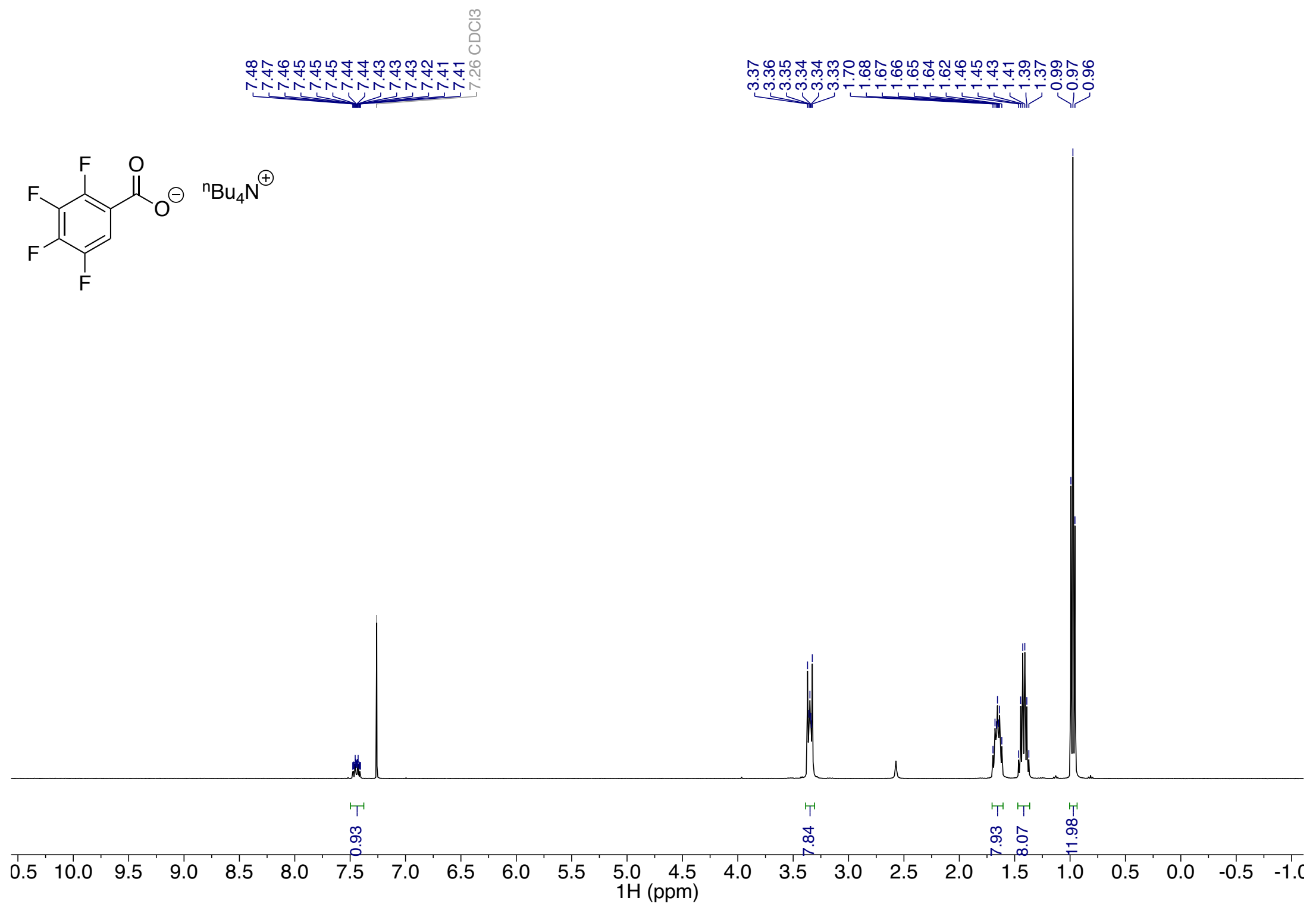


${ }^{13} \mathrm{C}$ NMR $\left(100 \mathrm{MHz}, \mathrm{CDCl}_{3}\right)$
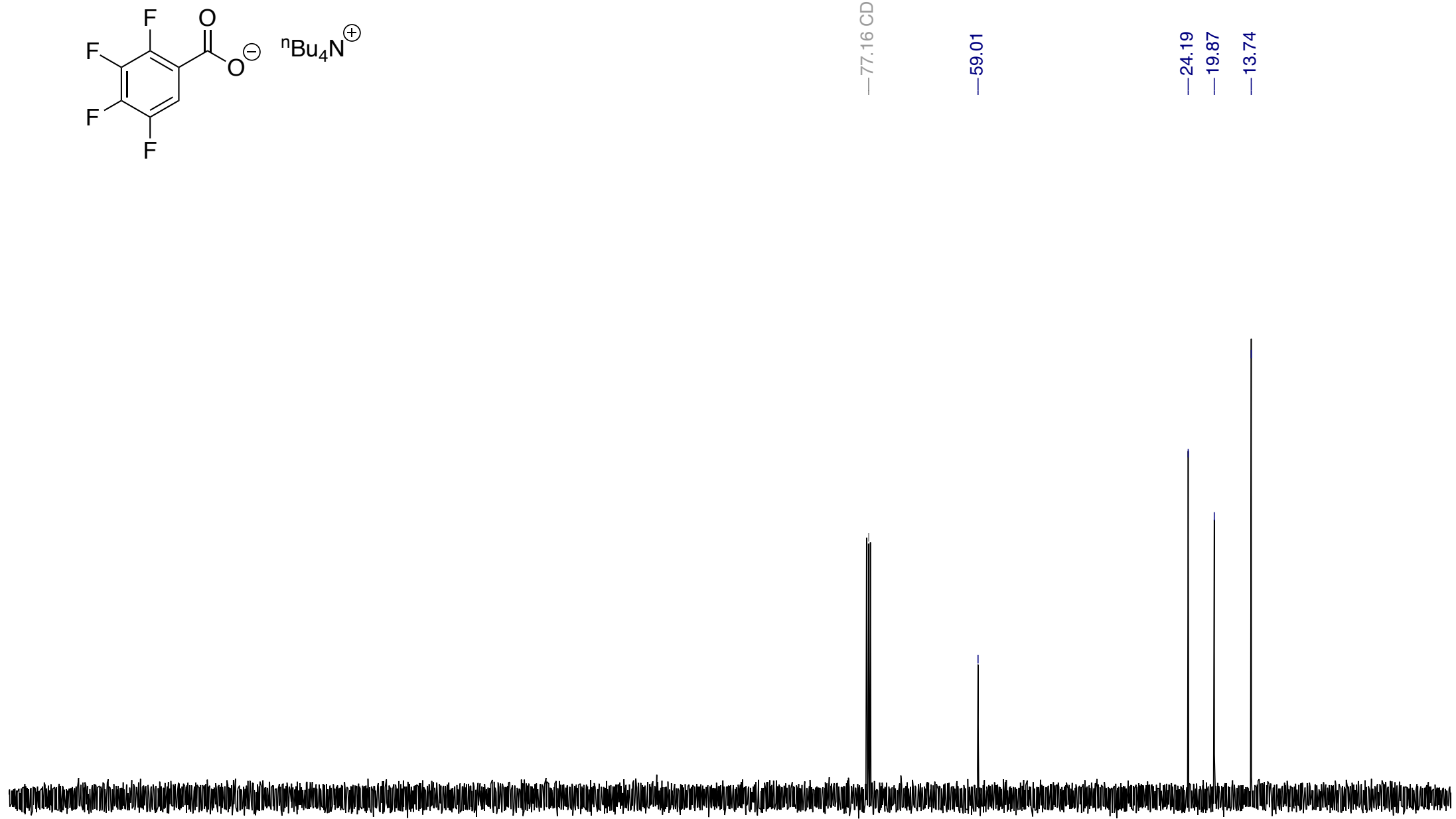

$\begin{array}{llllllllllll}210 & 200 & 190 & 180 & 170 & 160 & 150 & 140 & 130 & 120 & 110 & 100\end{array}$ $1 \mathrm{H}(\mathrm{ppm})$ 
Tetrabutylammonium 3,4,5-trifluorobenzoate

${ }^{1} \mathrm{H} \mathrm{NMR}\left(400 \mathrm{MHz}, \mathrm{CDCl}_{3}\right)$

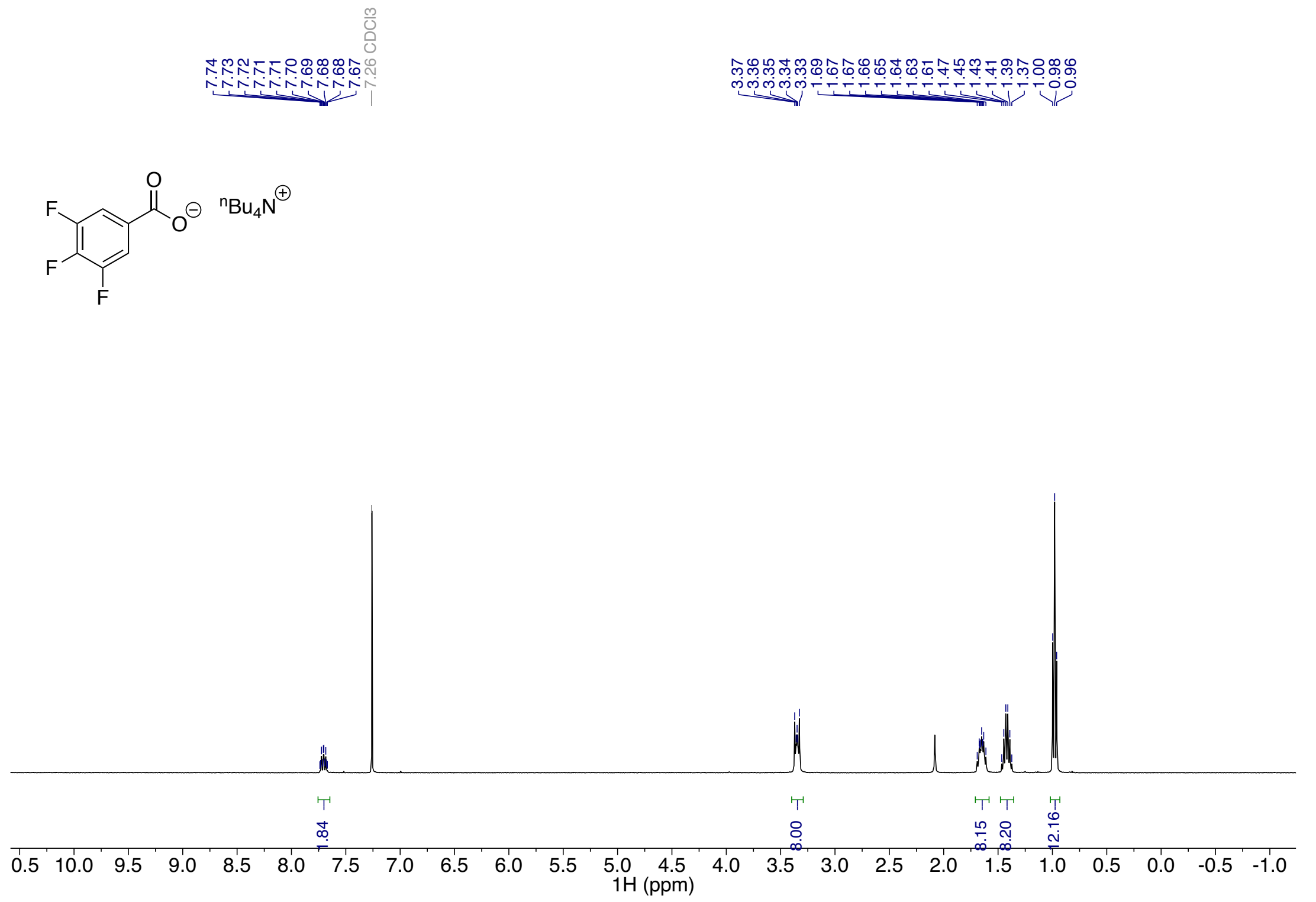


${ }^{13} \mathrm{C}$ NMR $\left(100 \mathrm{MHz}, \mathrm{CDCl}_{3}\right)$
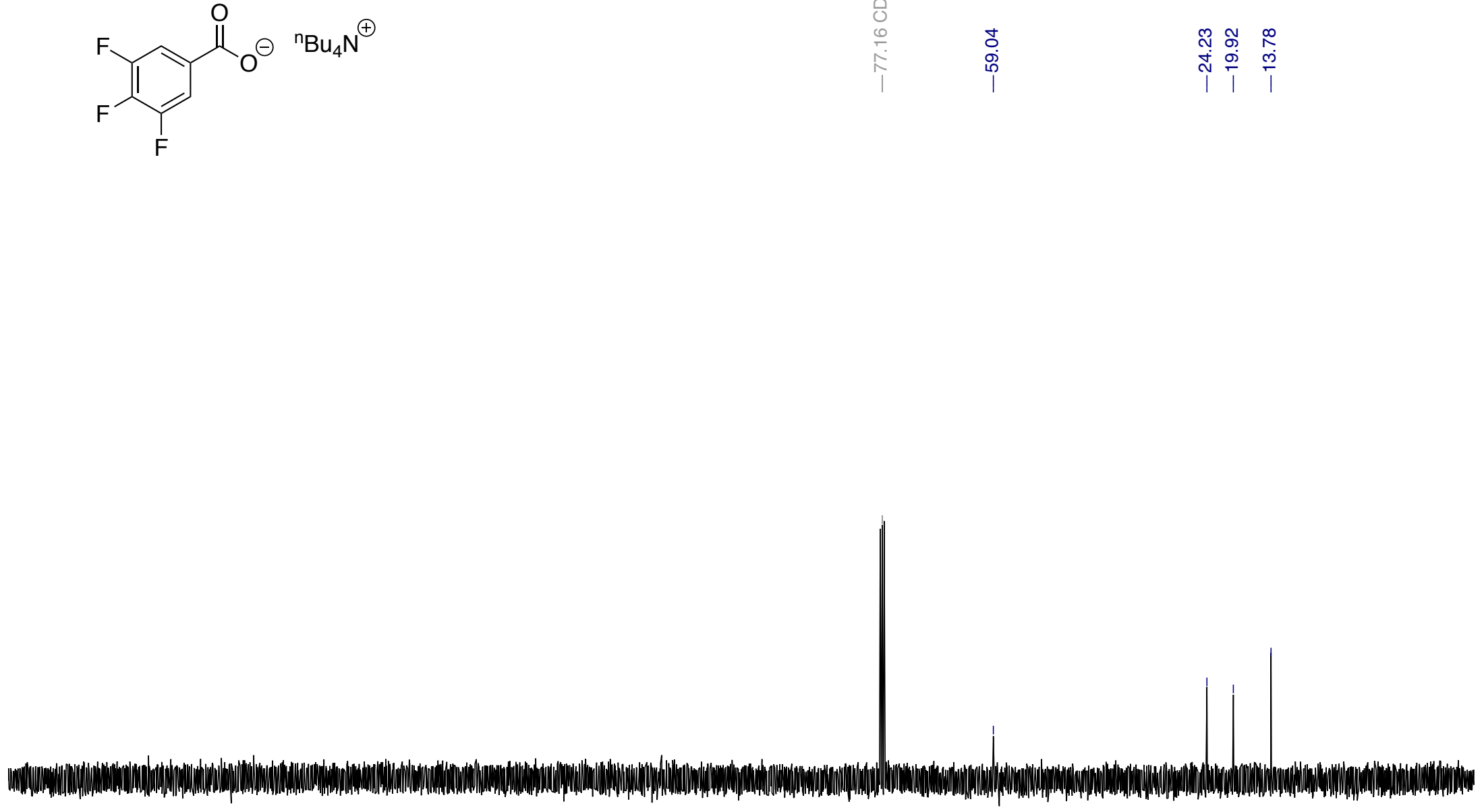

$\begin{array}{llllllllllll}210 & 200 & 190 & 180 & 170 & 160 & 150 & 140 & 130 & 120 & 110 & 100\end{array}$ $13 \mathrm{C}(\mathrm{ppm})$ 
Sodium dibutylphosphate

${ }^{1} \mathrm{H}$ NMR (500 MHz, $\mathrm{CDCl}_{3}$ )

\begin{tabular}{|c|}
\hline $\begin{array}{c}\mathrm{O} \\
\mathrm{BuO}-{ }_{\mathrm{P}}^{\mathrm{P}}-\mathrm{OBu} \\
\mathrm{O}^{-} \mathrm{Na}^{+}\end{array}$ \\
\hline
\end{tabular}
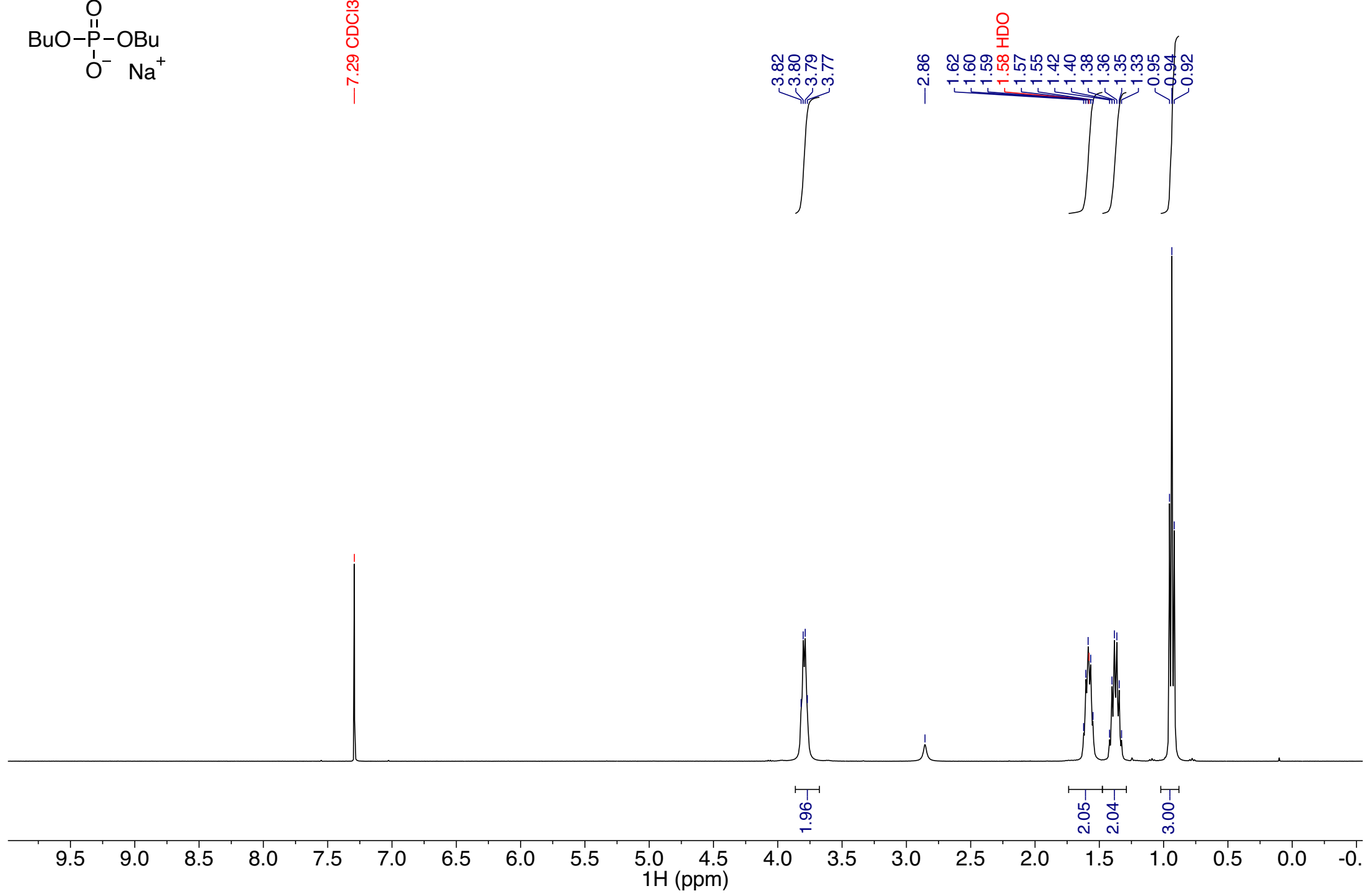
${ }^{13} \mathrm{C}$ NMR $\left(125 \mathrm{MHz}, \mathrm{CDCl}_{3}\right)$

$$
\begin{gathered}
\mathrm{O} \\
\mathrm{BuO}-\stackrel{\mathrm{P}}{\mathrm{I}}-\mathrm{OBu} \\
\mathrm{O}^{-} \mathrm{Na}^{+}
\end{gathered}
$$

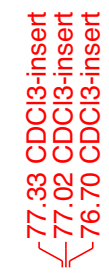

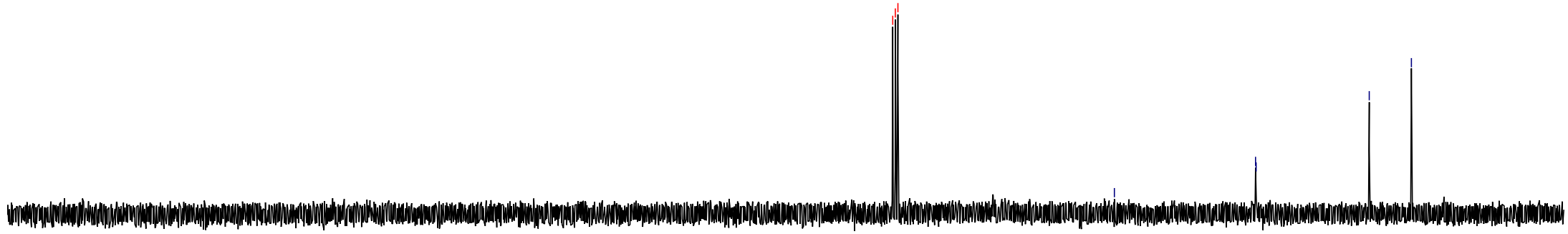

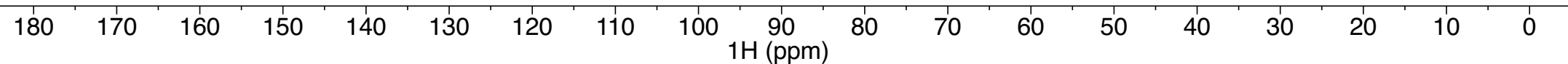


${ }^{31} \mathrm{P}$ NMR $\left(121 \mathrm{MHz}, \mathrm{CDCl}_{3}\right)$

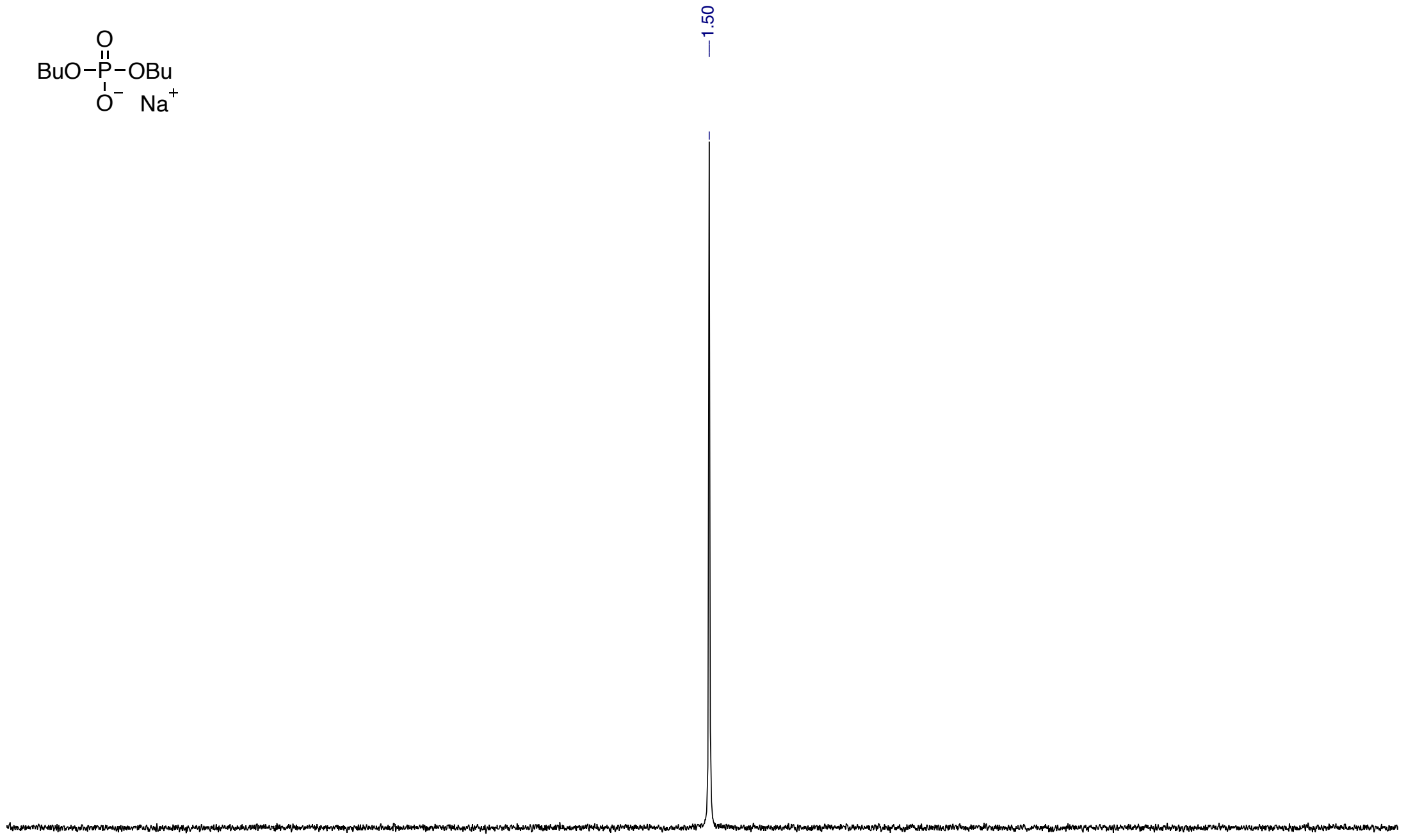


Tetrabutylammonium diphenylphosphate

${ }^{1} \mathrm{H} \mathrm{NMR} \mathrm{(500} \mathrm{MHz,} \mathrm{CDCl}_{3}$ )

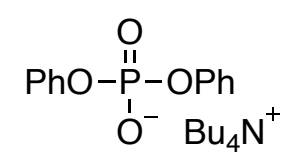

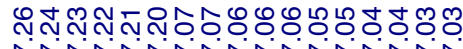

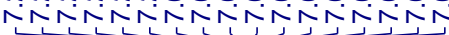

$\mathrm{O}^{-} \mathrm{Bu}_{4} \mathrm{~N}^{+}$
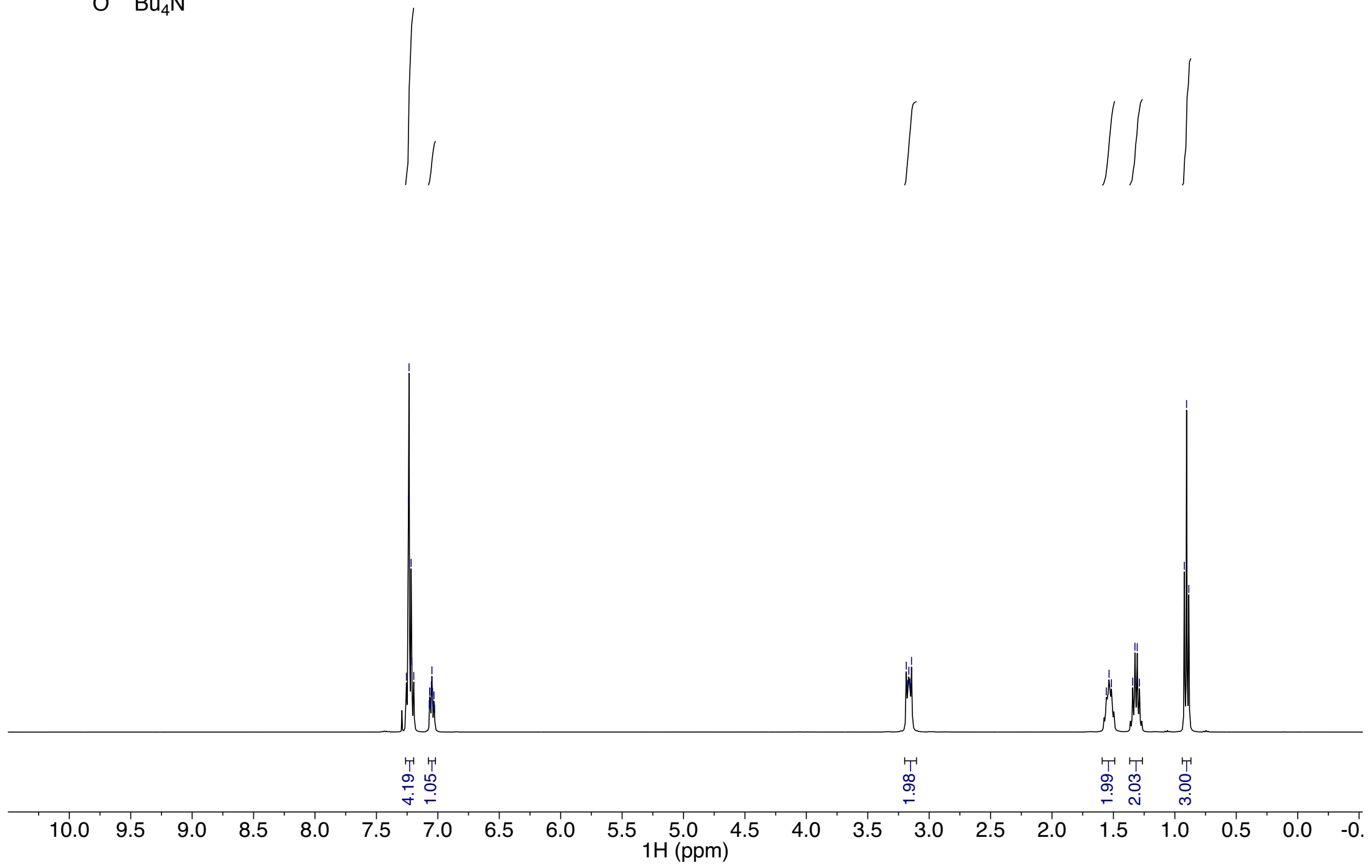

$\mathrm{S} 140$ 
${ }^{13} \mathrm{C} \mathrm{NMR}\left(125 \mathrm{MHz}, \mathrm{CDCl}_{3}\right)$

$$
\begin{gathered}
\mathrm{O} \\
\mathrm{PhO}-\stackrel{\mathrm{P}}{\mathrm{P}}-\mathrm{OPh} \\
\mathrm{O}^{-} \mathrm{Bu}_{4} \mathrm{~N}^{+}
\end{gathered}
$$
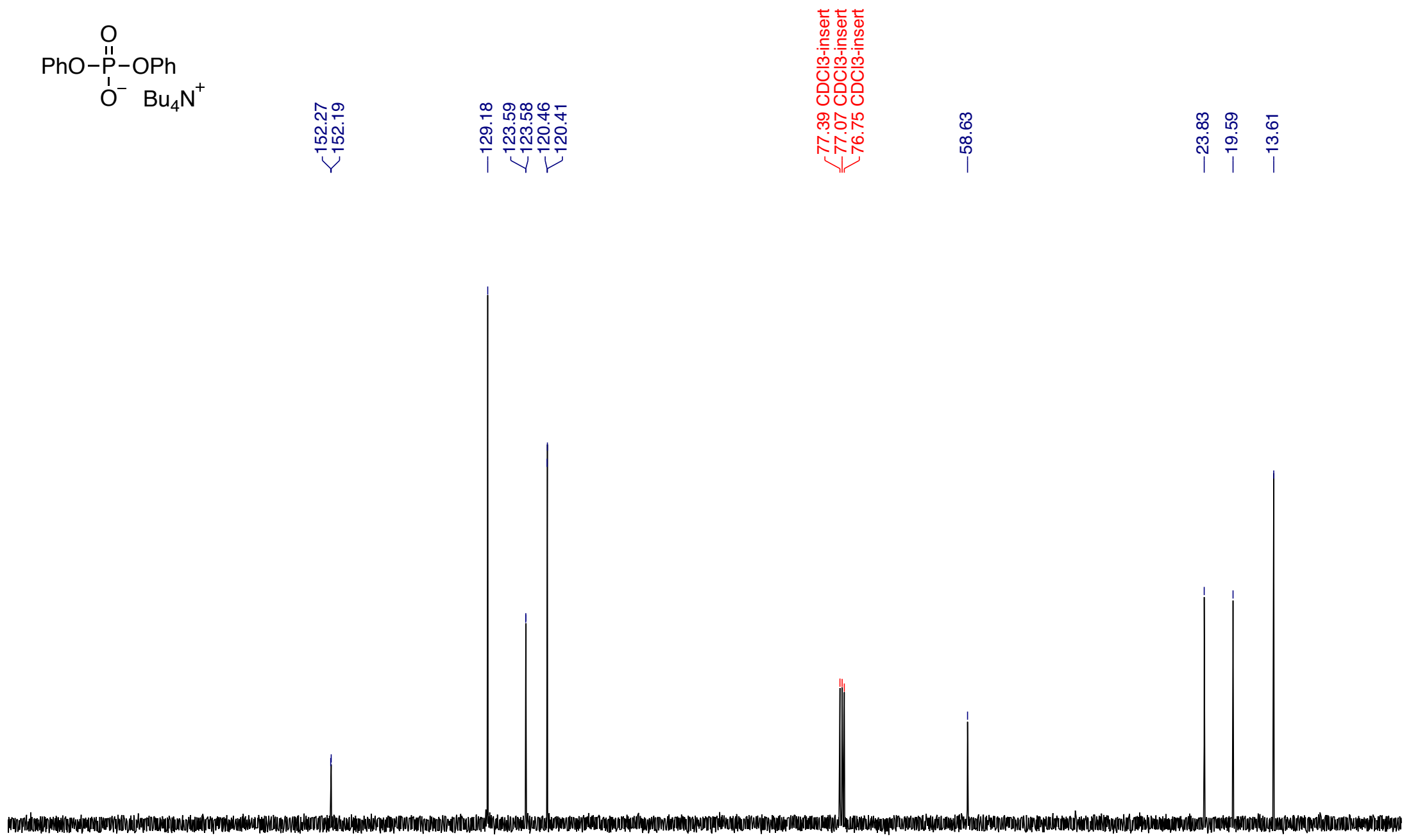

$190 \quad 180$
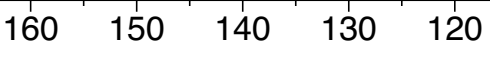
$110 \quad 100 \quad 90$
$13 C(\mathrm{ppm})$ 
${ }^{31} \mathrm{P}$ NMR (121 MHz, $\left.\mathrm{CDCl}_{3}\right)$

$$
\begin{aligned}
& \mathrm{O} \\
& \mathrm{PhO}-\stackrel{P}{1}-\mathrm{OPh} \\
& \mathrm{O}^{-} \mathrm{Bu}_{4} \mathrm{~N}^{+}
\end{aligned}
$$

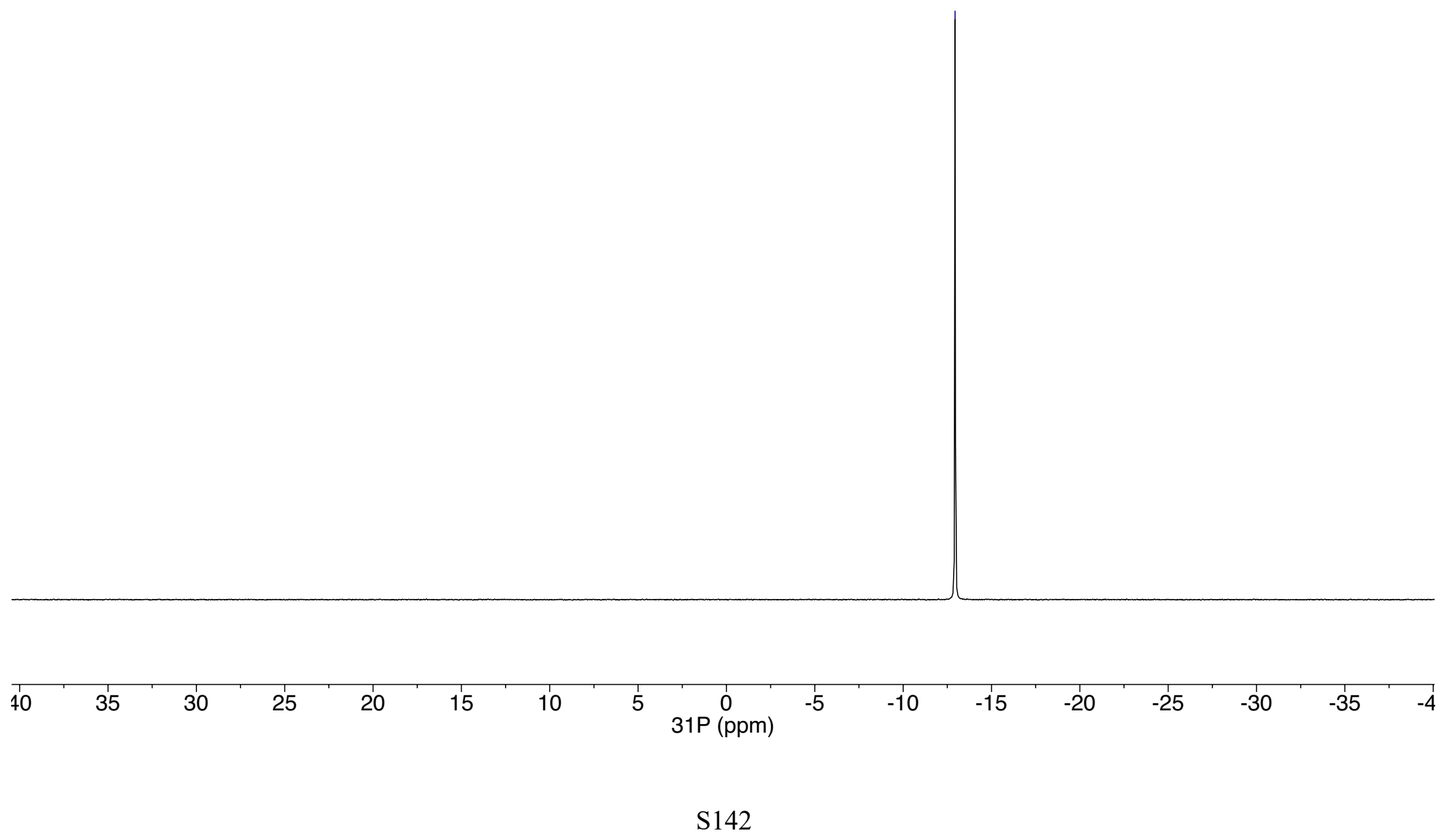


3b - Methyl 2-O-(tert-butyloxycarbonyl) $\alpha$-D-glucopyranoside

${ }^{1} \mathrm{H} \mathrm{NMR}\left(500 \mathrm{MHz}, \mathrm{CDCl}_{3}\right)$

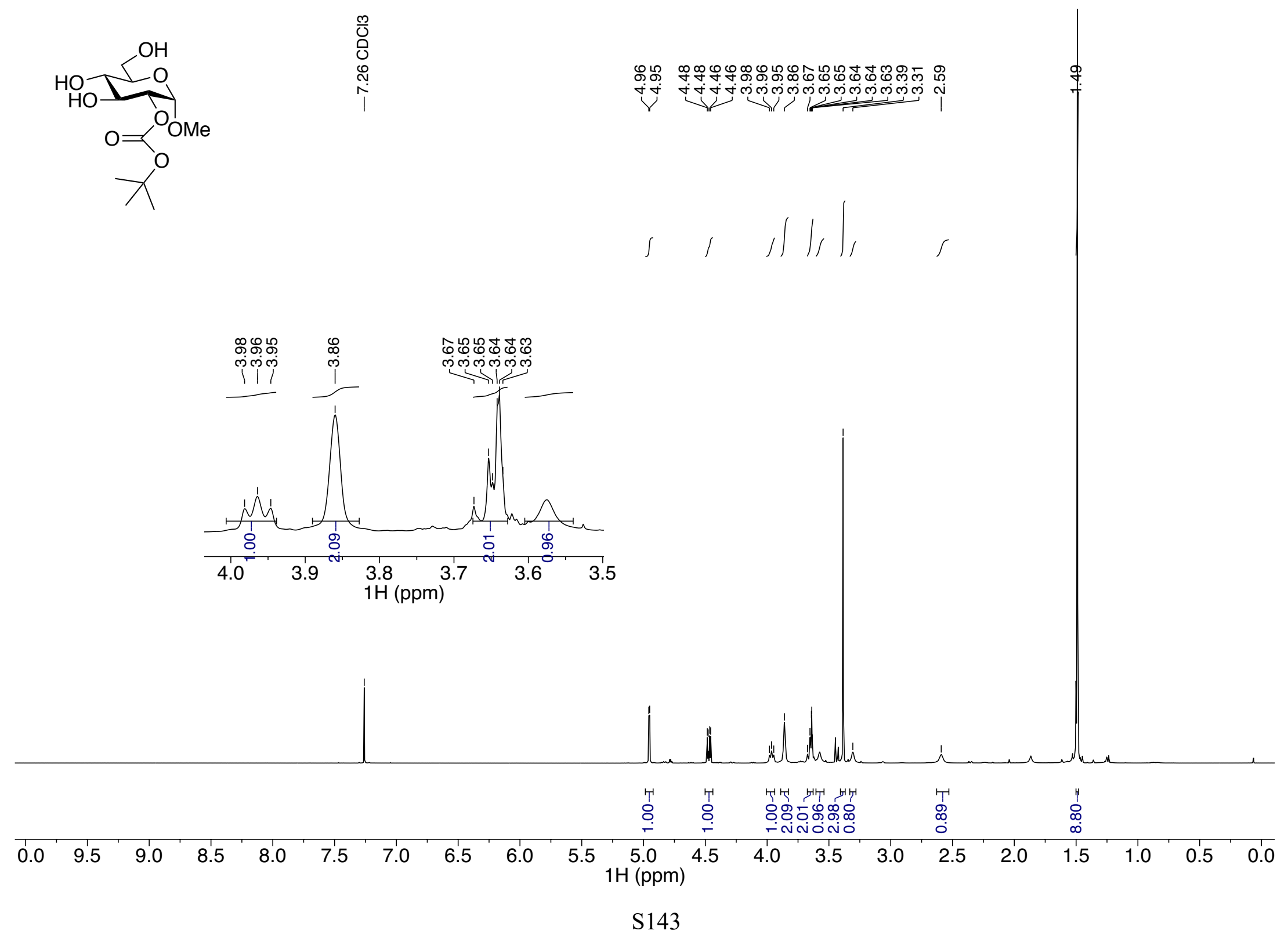


3b $-{ }^{13} \mathrm{C}$ NMR $\left(125 \mathrm{MHz}, \mathrm{CDCl}_{3}\right)$
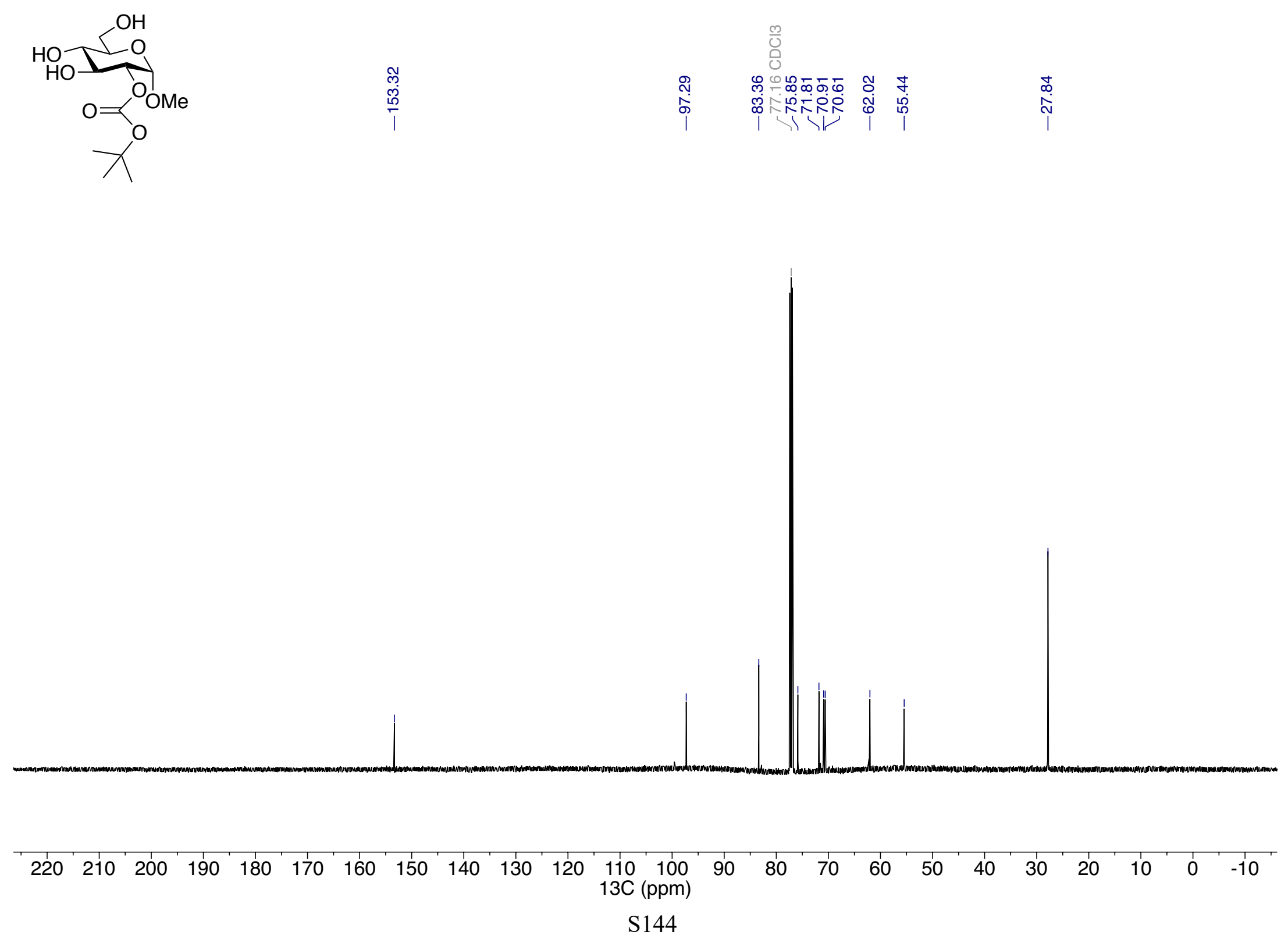


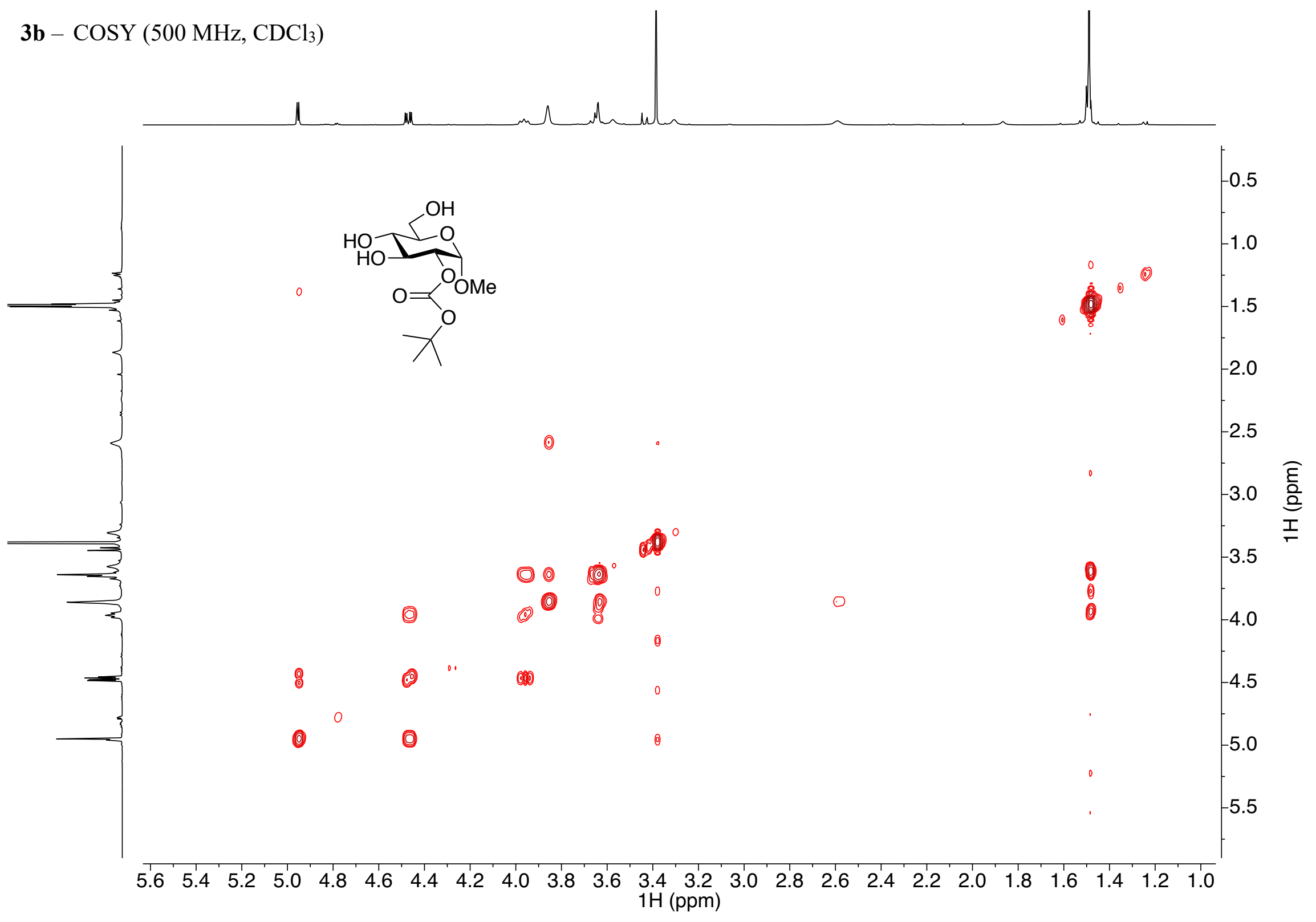

S145 
2c - Methyl 2,6-O-trimethylacteyl- $\beta$-D-glucopyranoside

${ }^{1} \mathrm{H}$ NMR (500 MHz, $\left.\mathrm{CDCl}_{3}\right)$
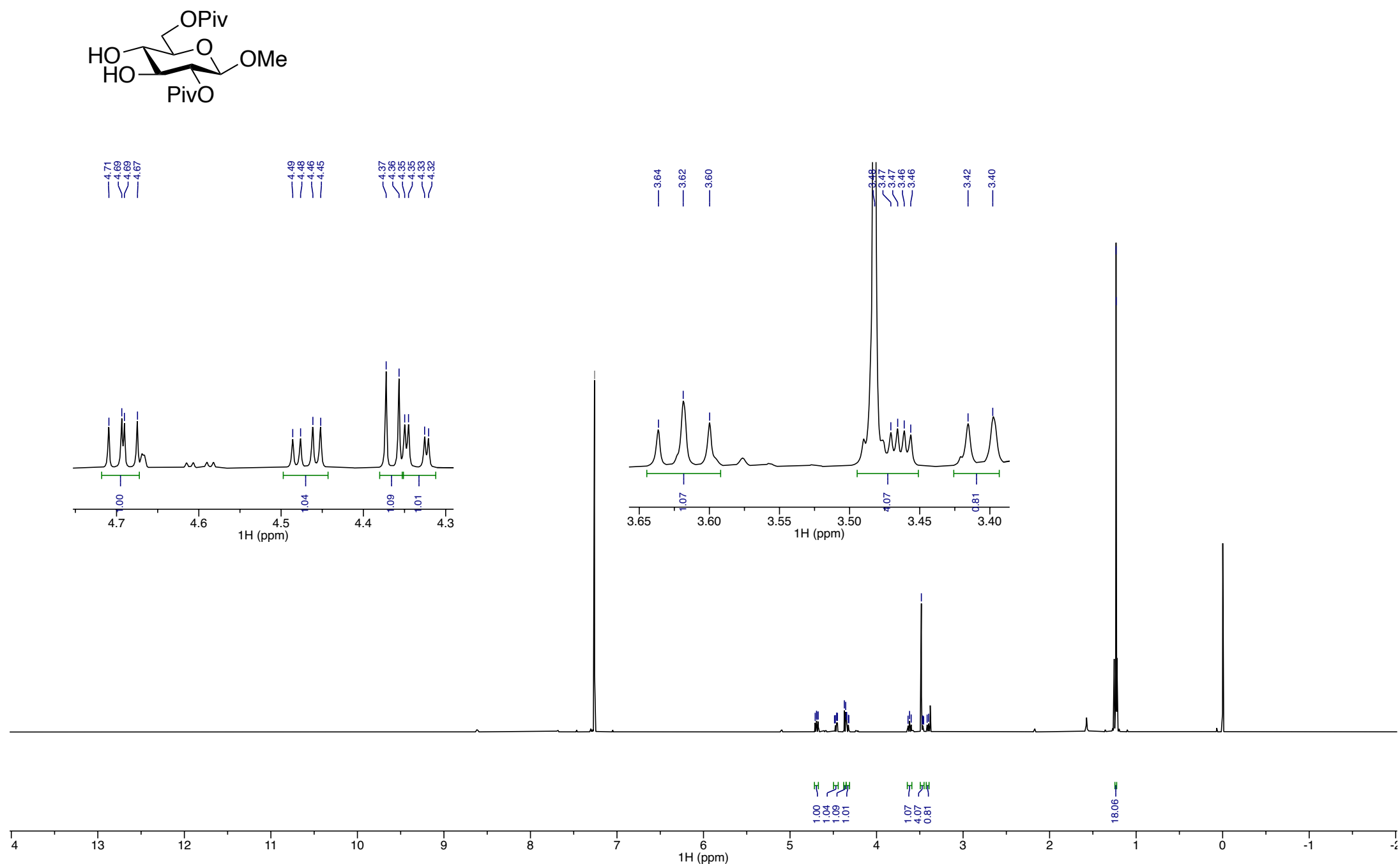
$2 \mathbf{c}-{ }^{13} \mathrm{C}$ NMR $\left(125 \mathrm{MHz}, \mathrm{CDCl}_{3}\right)$

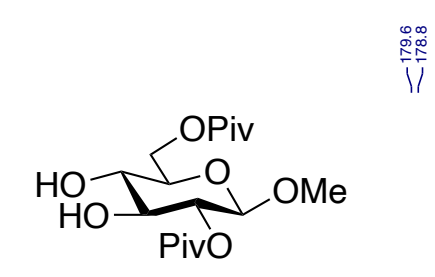

䈆

$$
\text { PivO } \mathrm{OMe}
$$




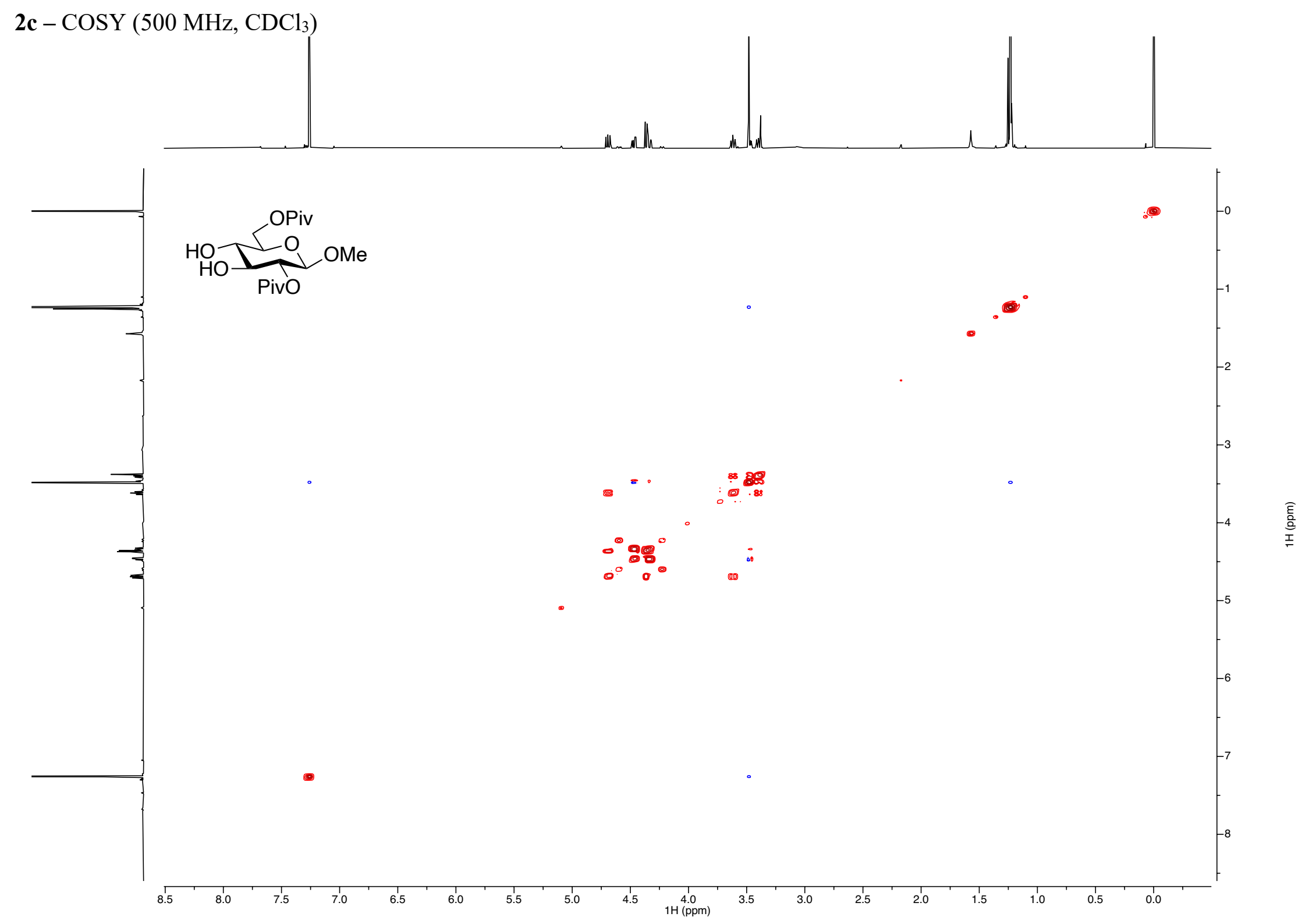

S148 
2d - Methyl 2-O-Trimethylacetyl-6-O-(2',3',4',6'-tetra-O-acetyl- $\beta$-D-galactopyranosyl)- $\alpha$-D-glucopyranoside ${ }^{1} \mathrm{H} \mathrm{NMR}\left(500 \mathrm{MHz}, \mathrm{CDCl}_{3}\right)$
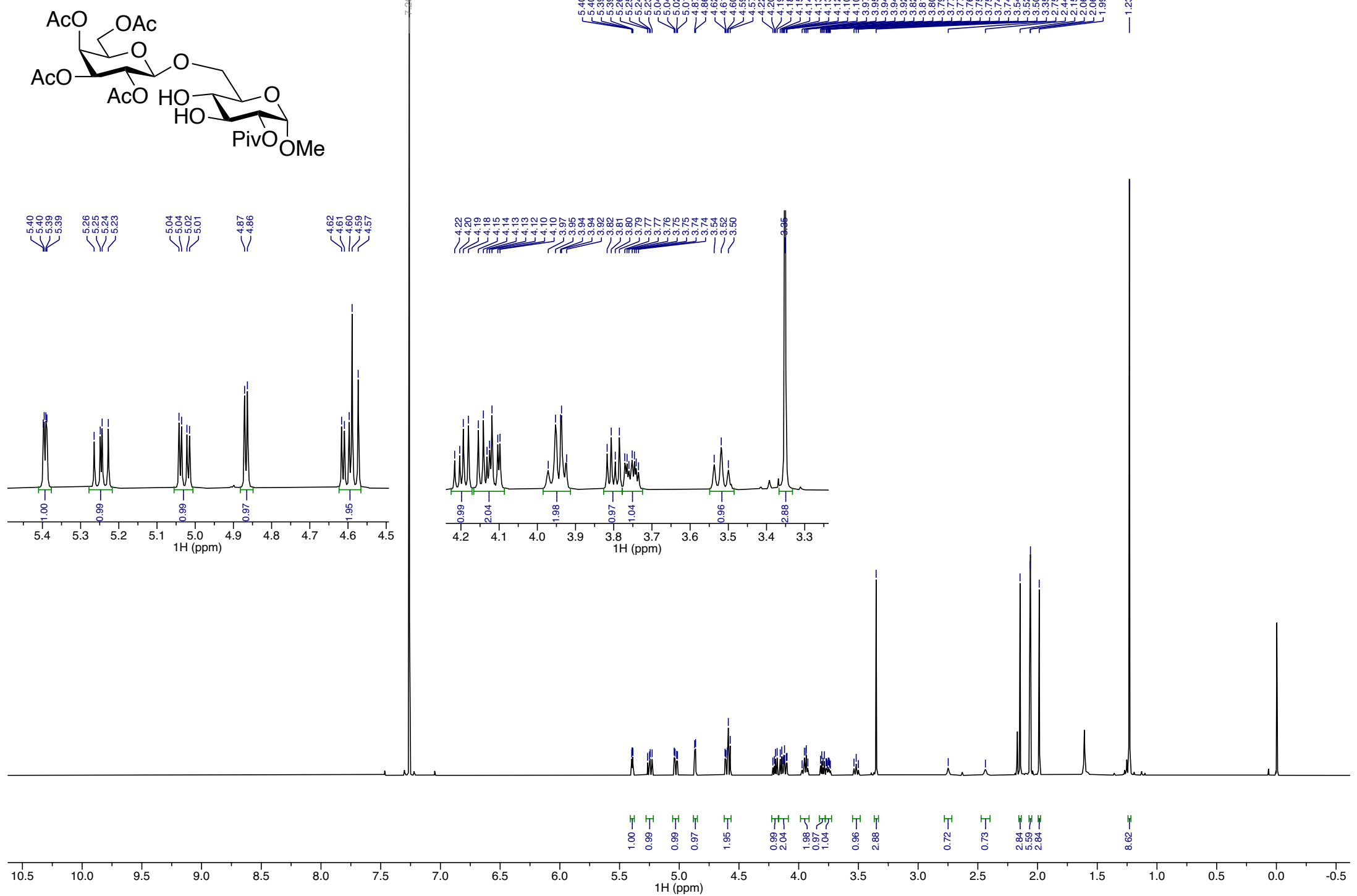

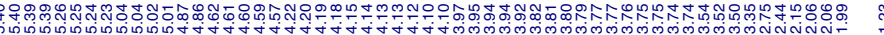


2d $-{ }^{13} \mathrm{C}$ NMR (126 MHz, $\left.\mathrm{CDCl}_{3}\right)$
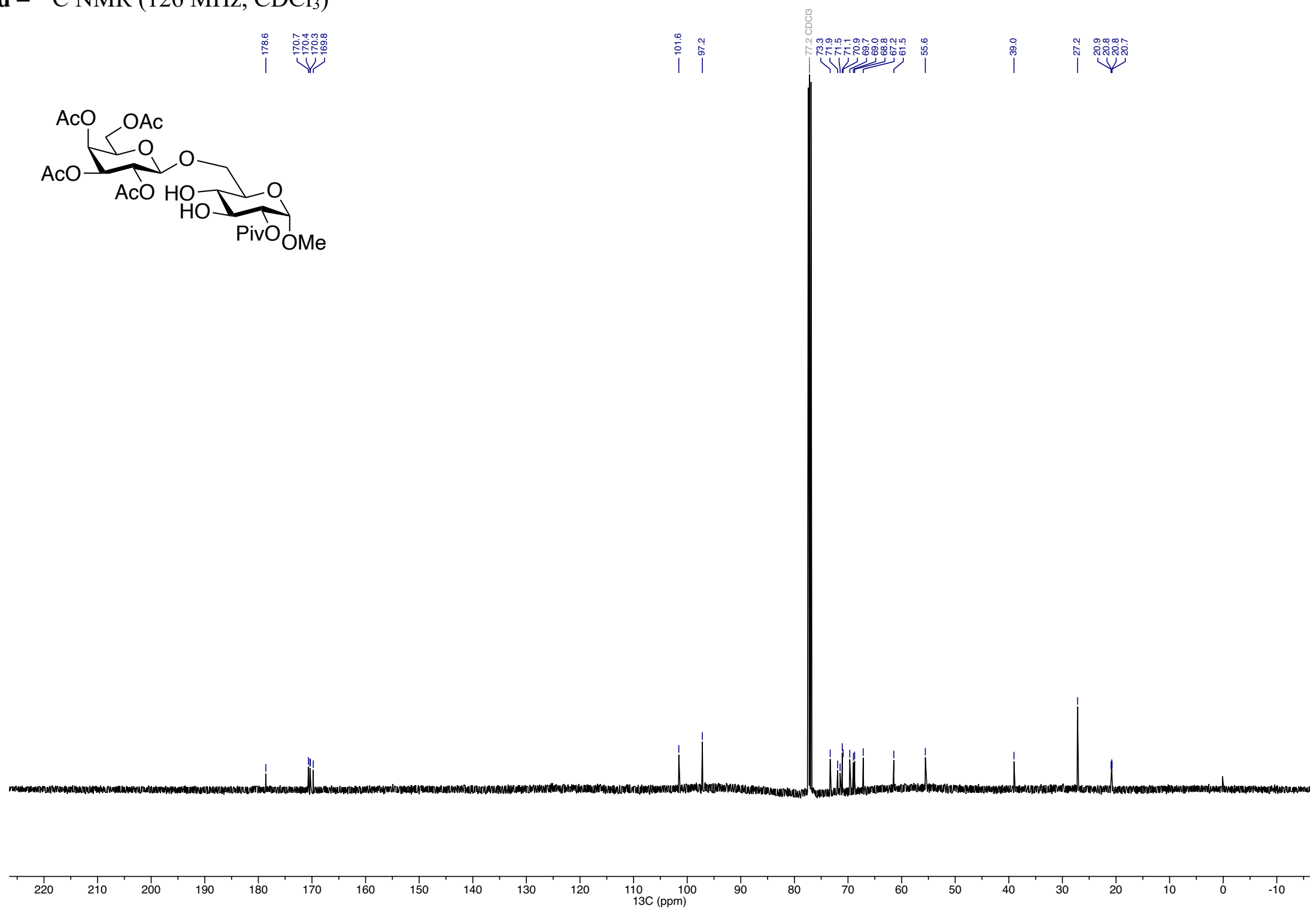

S150 
2d-COSY $\left(500 \mathrm{MHz}, \mathrm{CDCl}_{3}\right)$

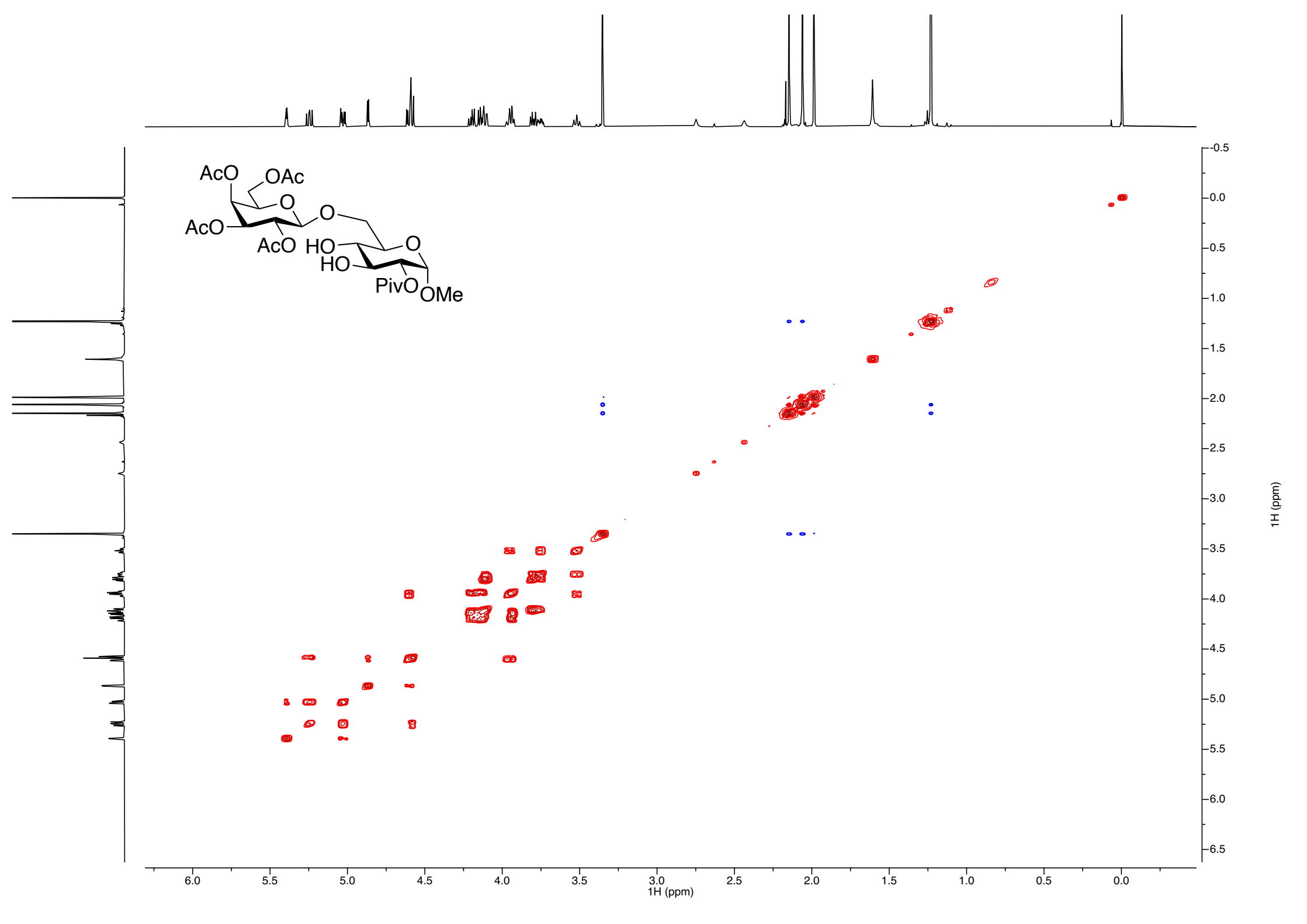


2e - Methyl 2-O-trimethylacetyl-6-O-(tert-butyldimethylsilyl)- $\alpha$-D-galactopyranoside ${ }^{1} \mathrm{H}$ NMR $\left(500 \mathrm{MHz}, \mathrm{CDCl}_{3}\right)$

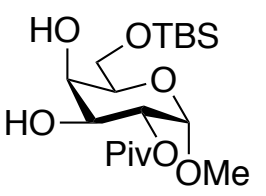

๓๐ $\frac{i}{2}$
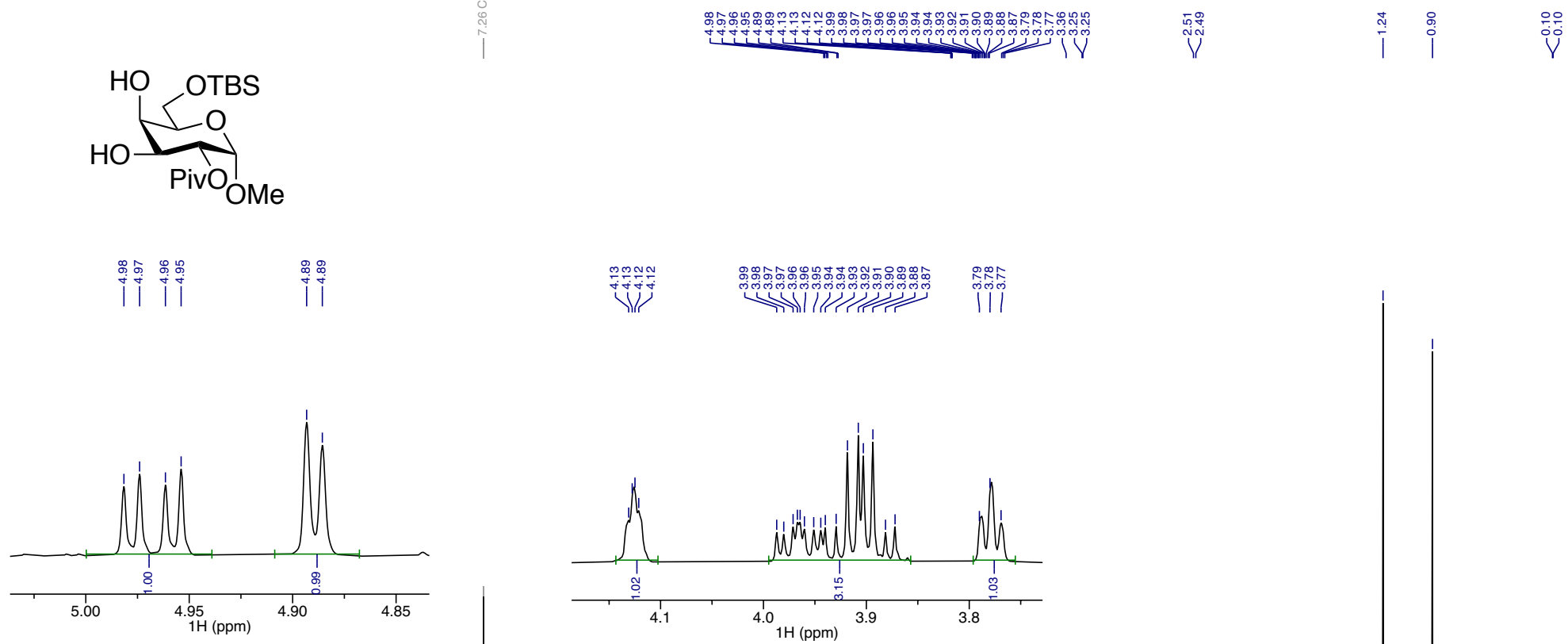

$\|$ L.

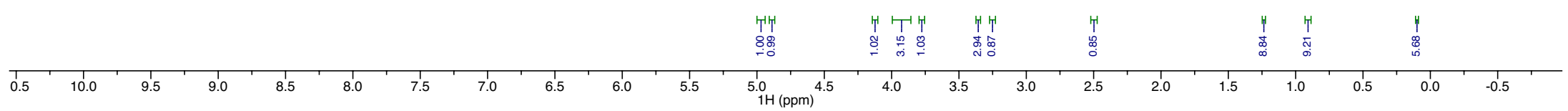


2e $-{ }^{13} \mathrm{C}$ NMR $\left(125 \mathrm{MHz}, \mathrm{CDCl}_{3}\right)$
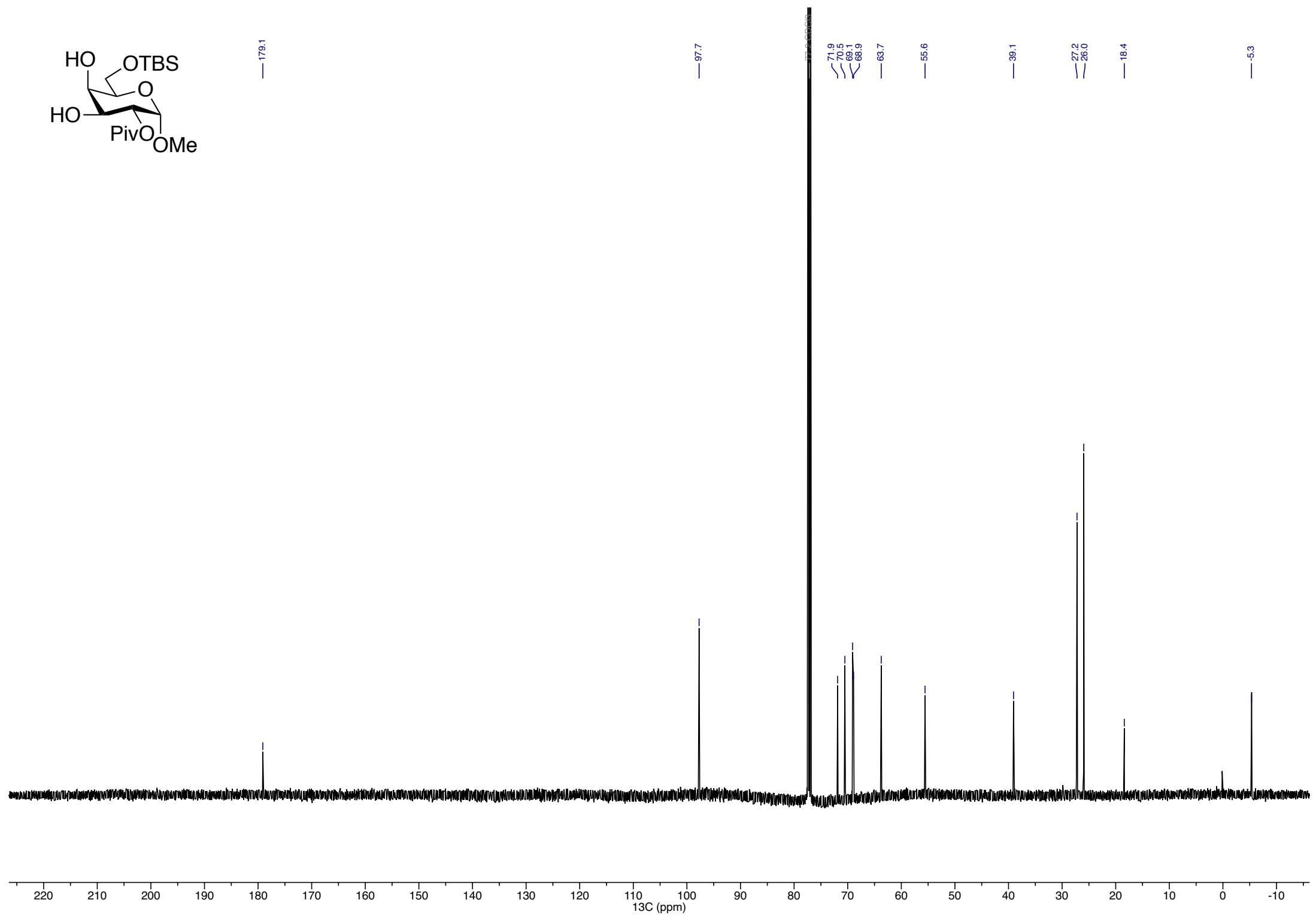

S153 
2e-COSY $\left(500 \mathrm{MHz}, \mathrm{CDCl}_{3}\right)$
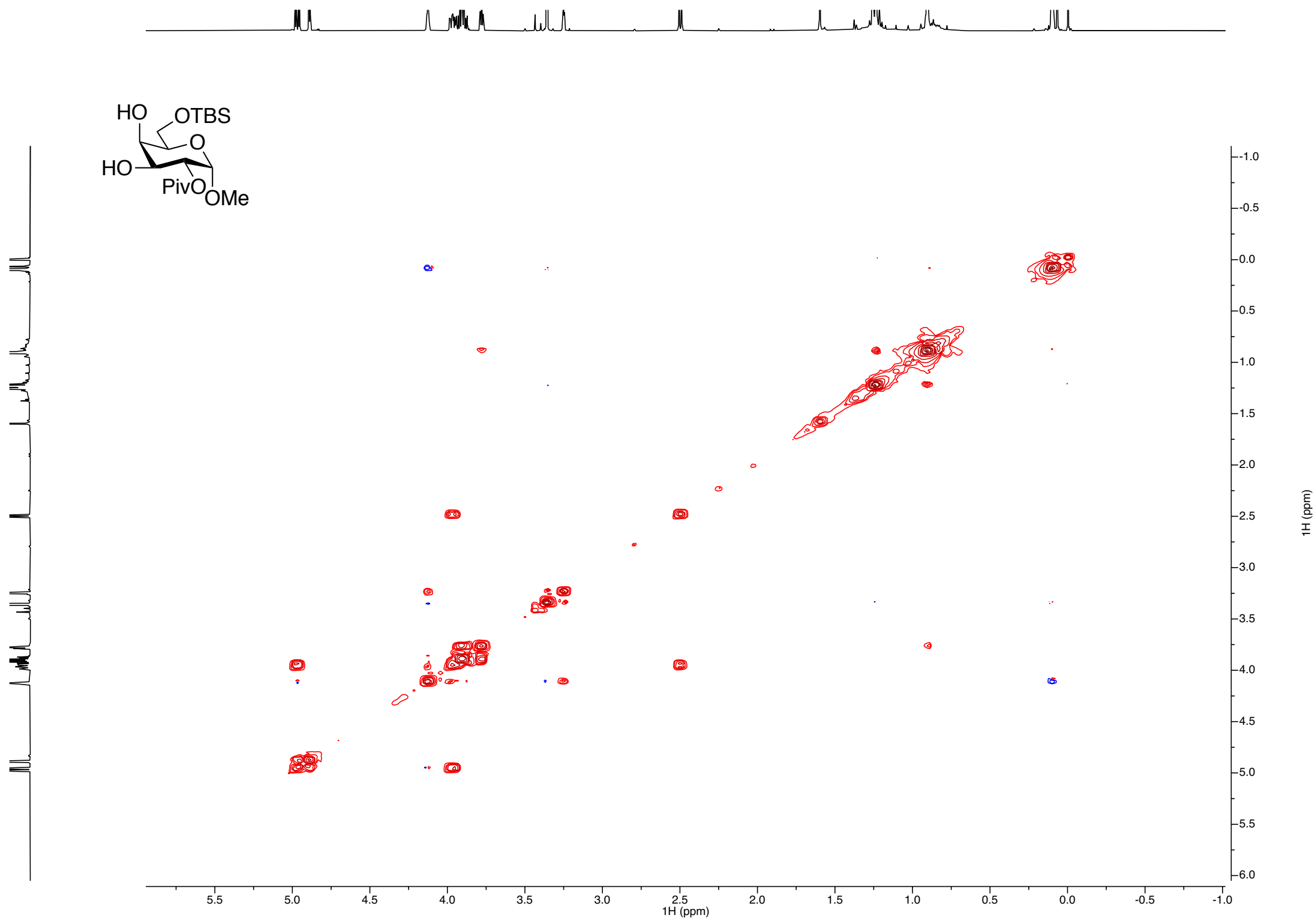
2g - Methyl 4-O-trimethylacetyl-6-O-(tert-butyldimethylsilyl)- $\alpha$-D-mannopyranoside

${ }^{1} \mathrm{H}$ NMR (400 MHz, $\left.\mathrm{CDCl}_{3}\right)$
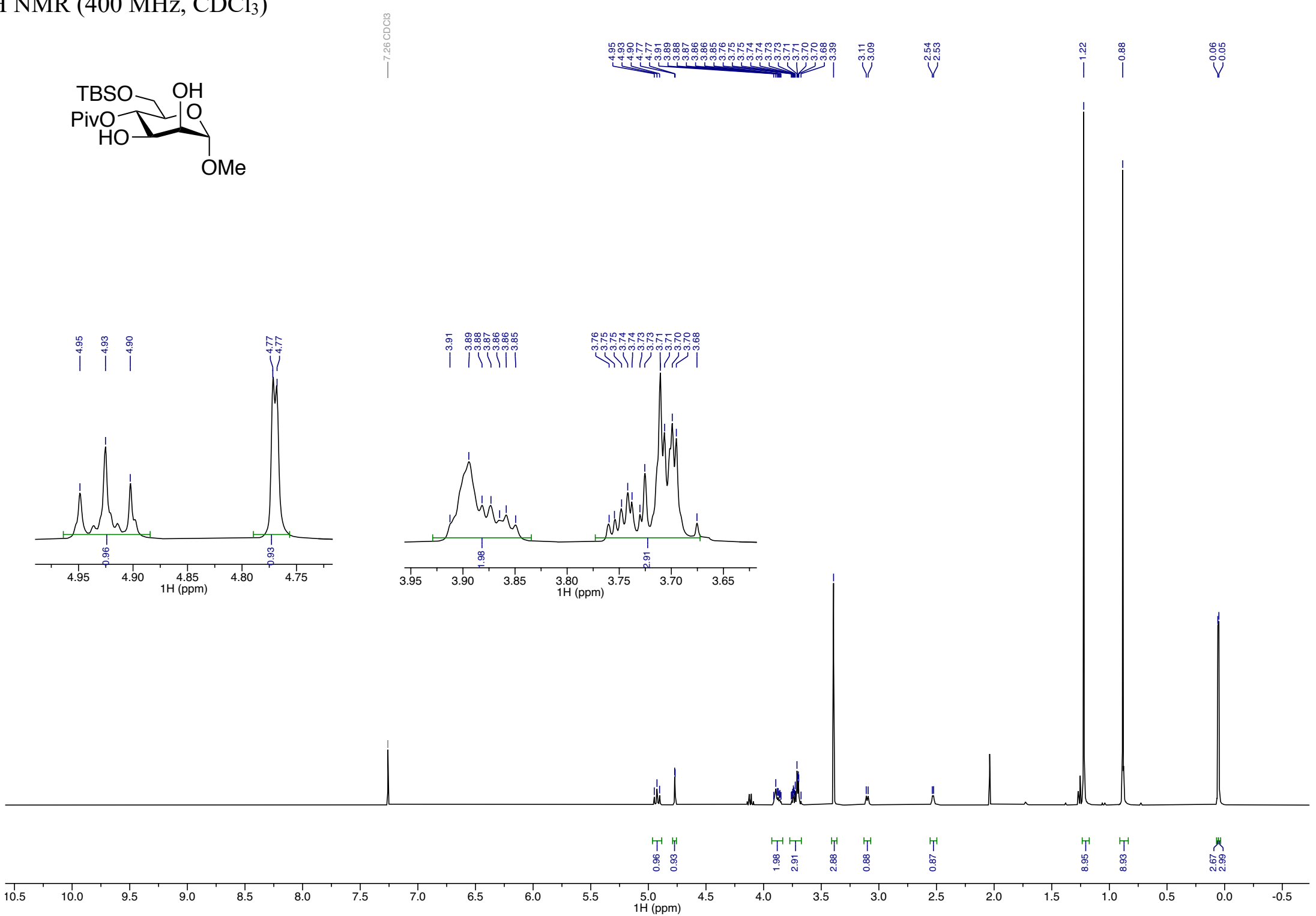
$2 \mathrm{~g}-{ }^{13} \mathrm{C}$ NMR $\left(100 \mathrm{MHz}, \mathrm{CDCl}_{3}\right)$

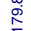

$\underbrace{\mathrm{TBSO}}_{\mathrm{OMe}}$

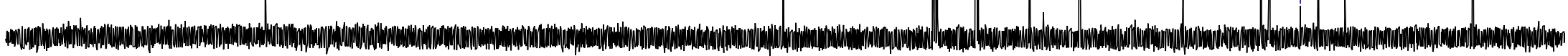




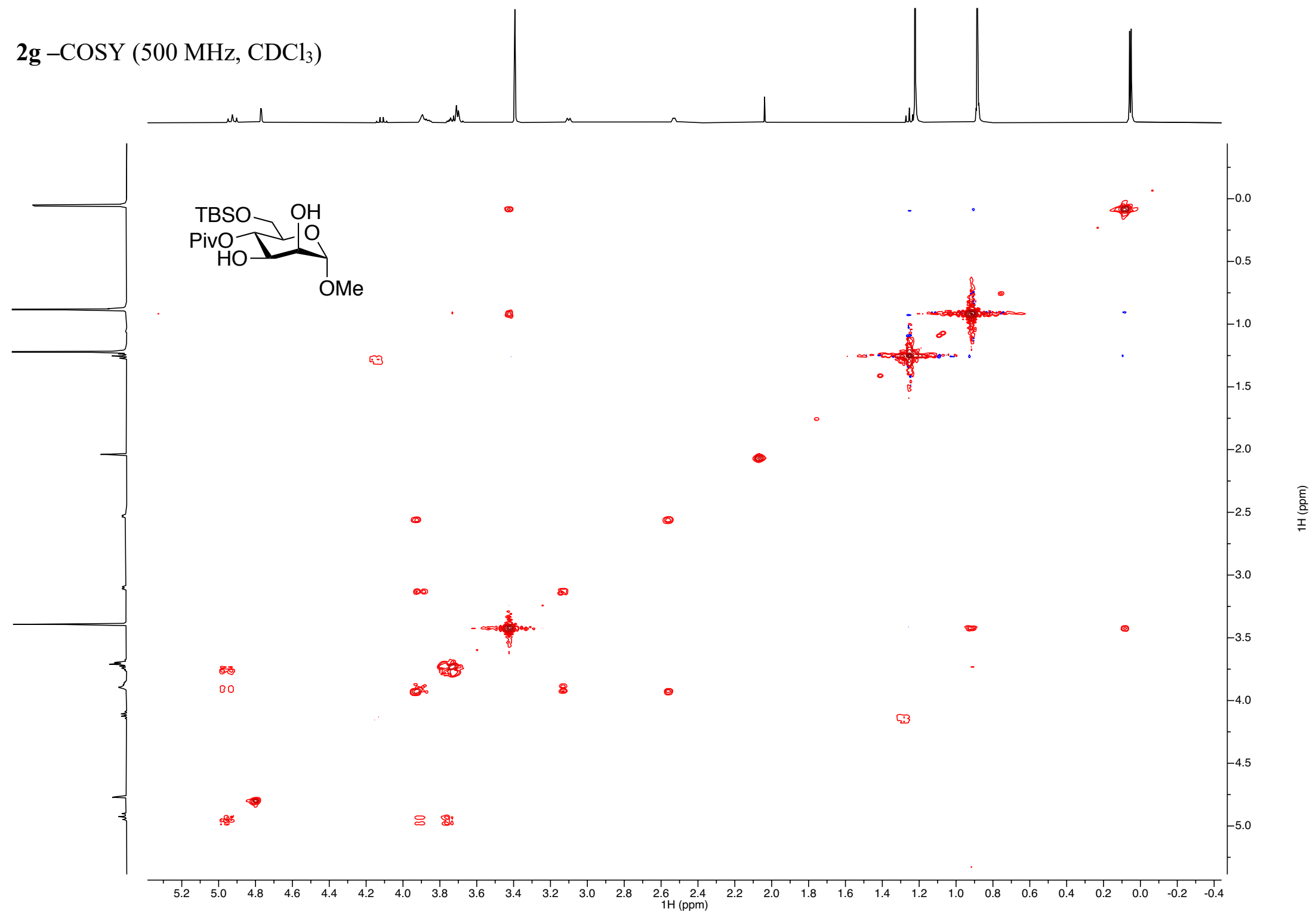

S157 


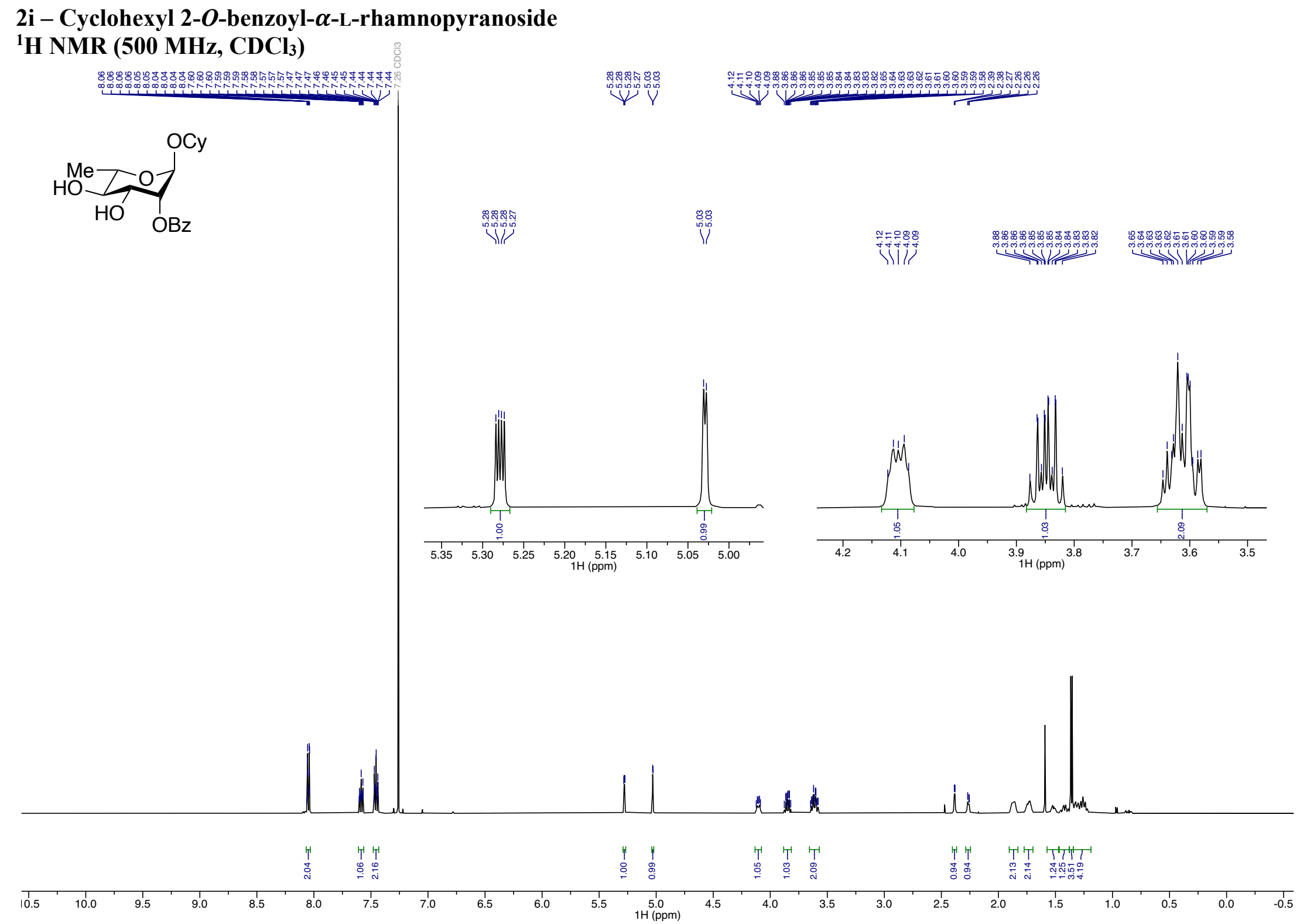


$\mathbf{2 i}-{ }^{13} \mathrm{C}$ NMR (125 MHz, CDCl3)
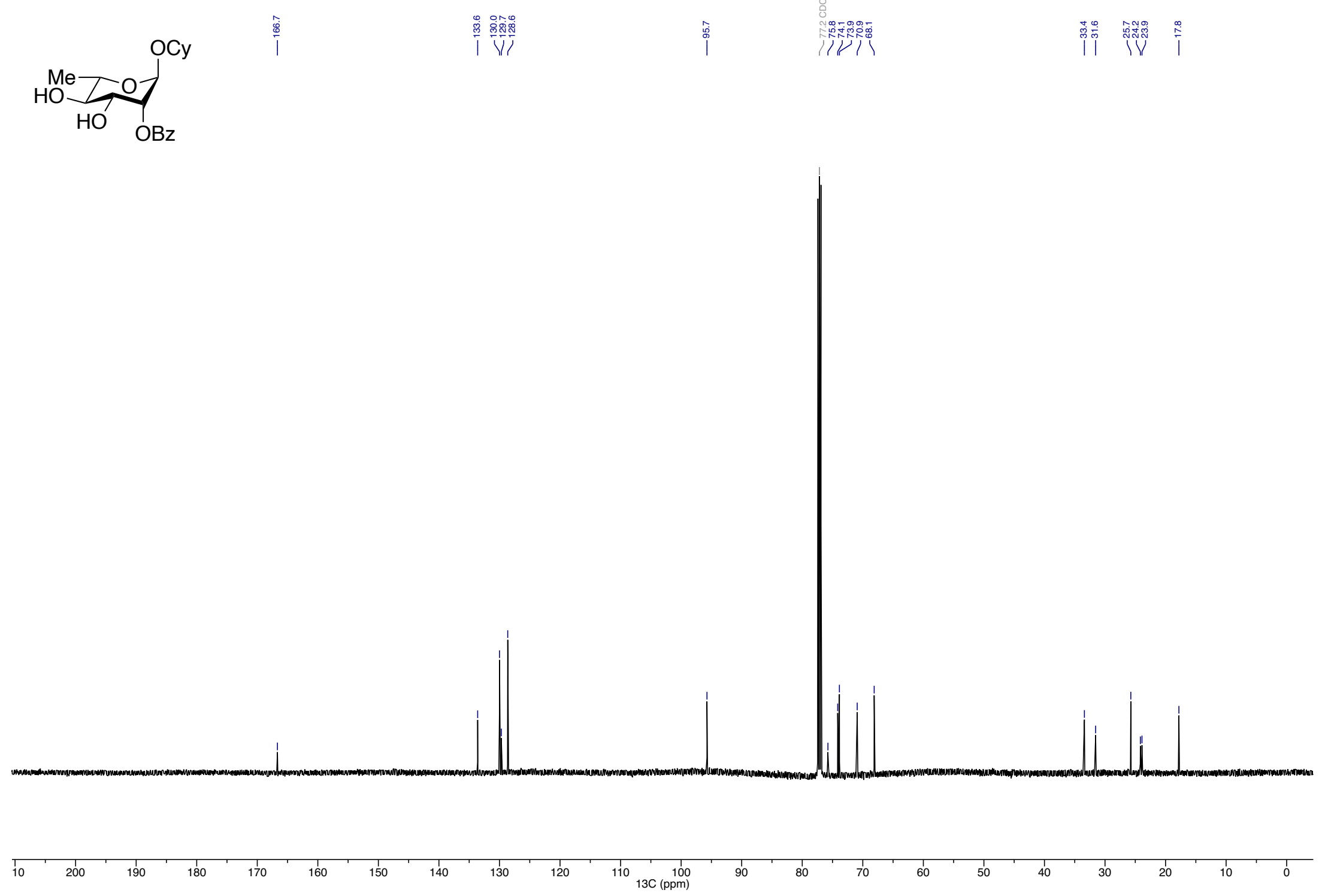


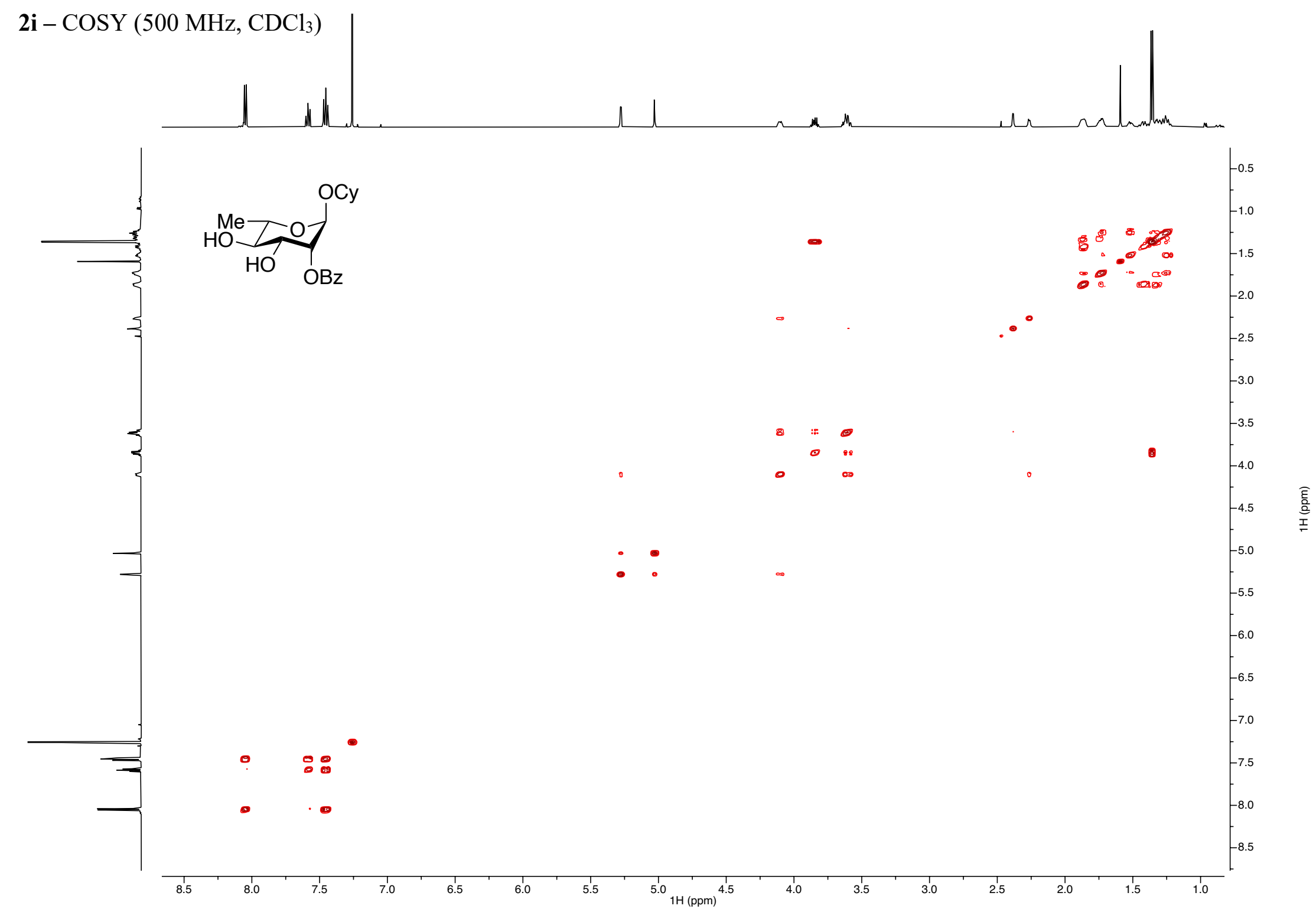




\section{$2 \mathrm{j}$ - 1,2,3,4-di-O-isopropylidene-6-O-(2-O-benzoyl- $\alpha$-L-rhamnopyranosyl)- $\alpha$-D-galactopyranoside}

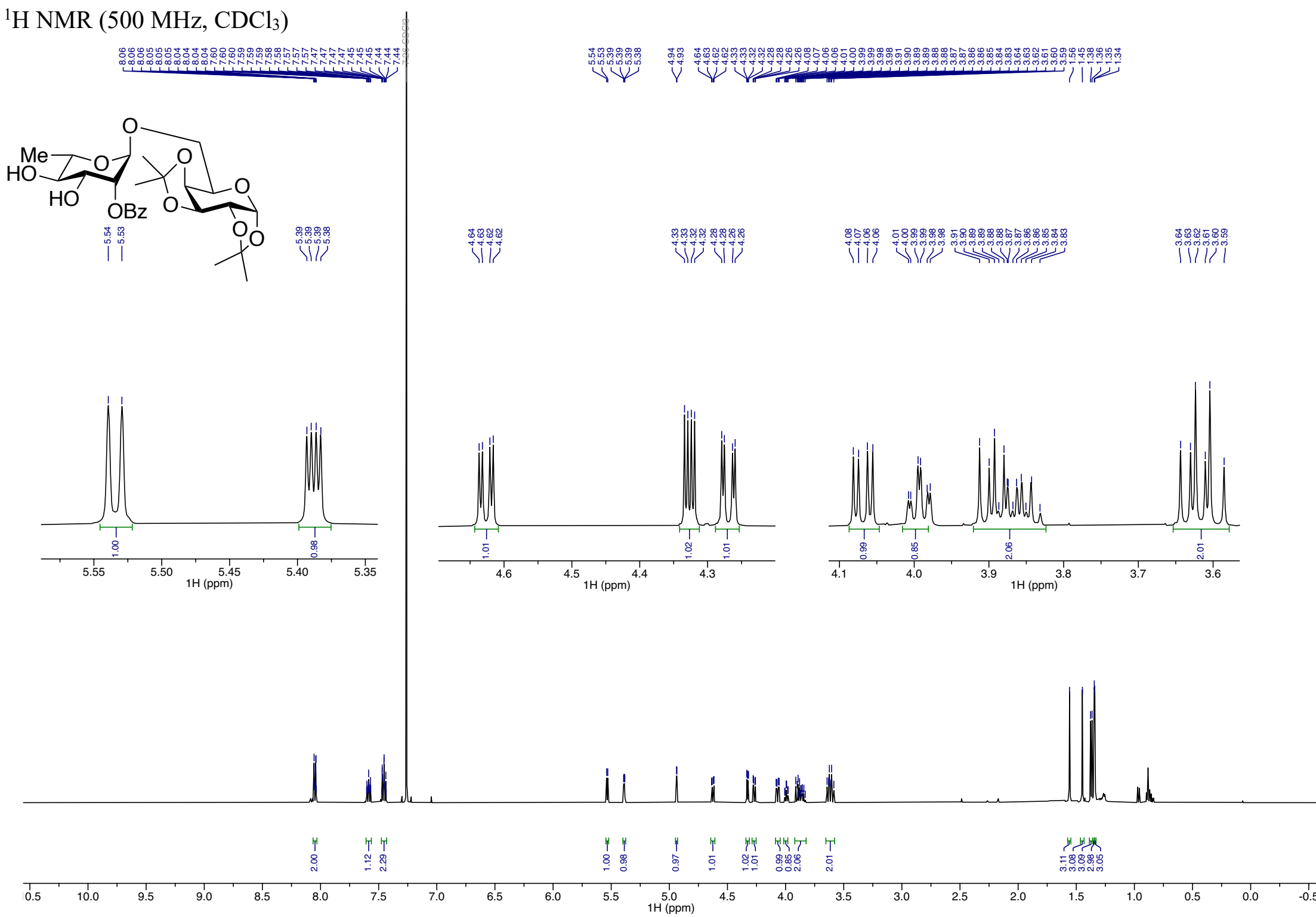


$\mathbf{2} \mathbf{j}-{ }^{13} \mathrm{C}$ NMR $\left(125 \mathrm{MHz}, \mathrm{CDCl}_{3}\right)$
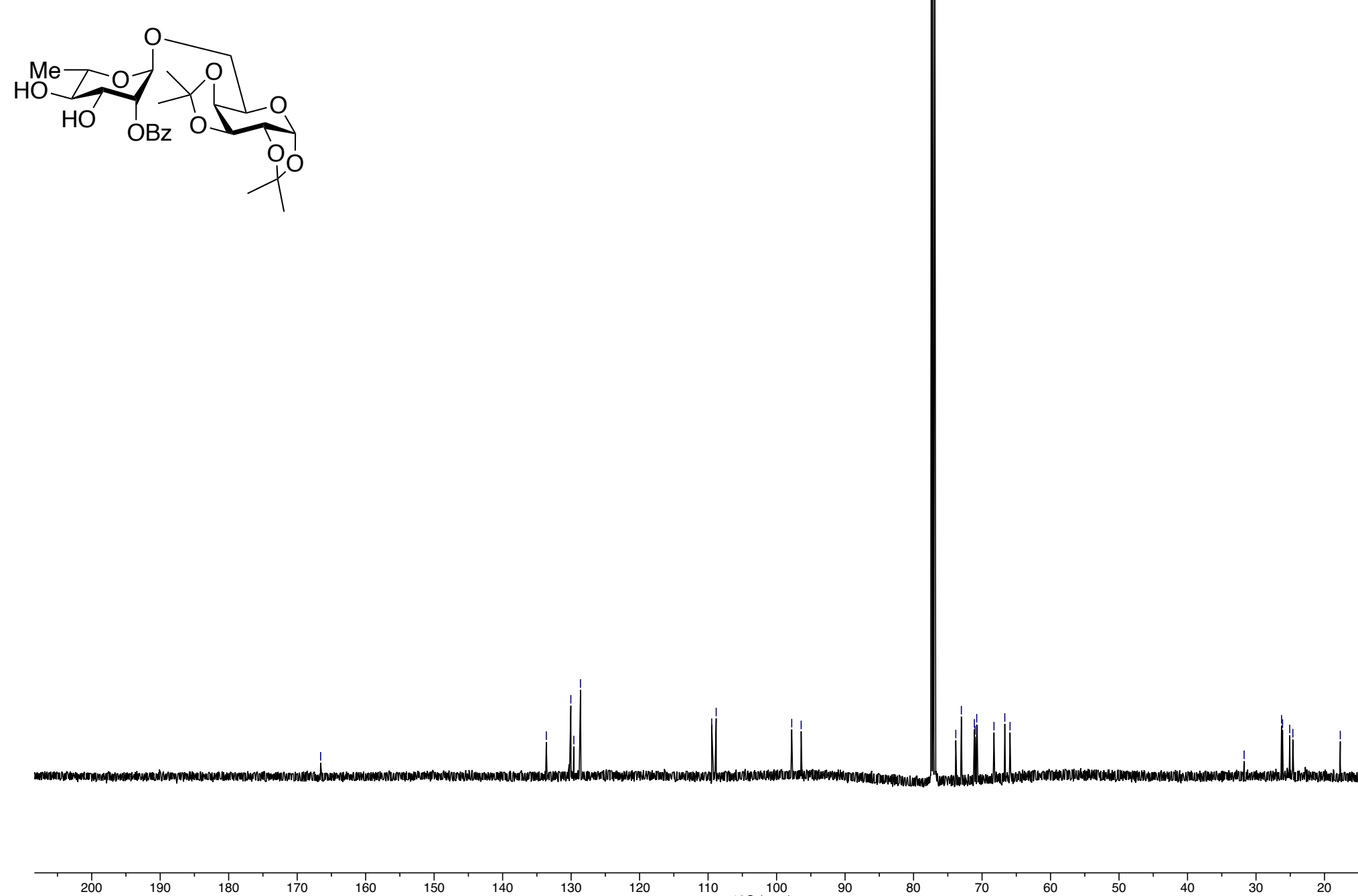


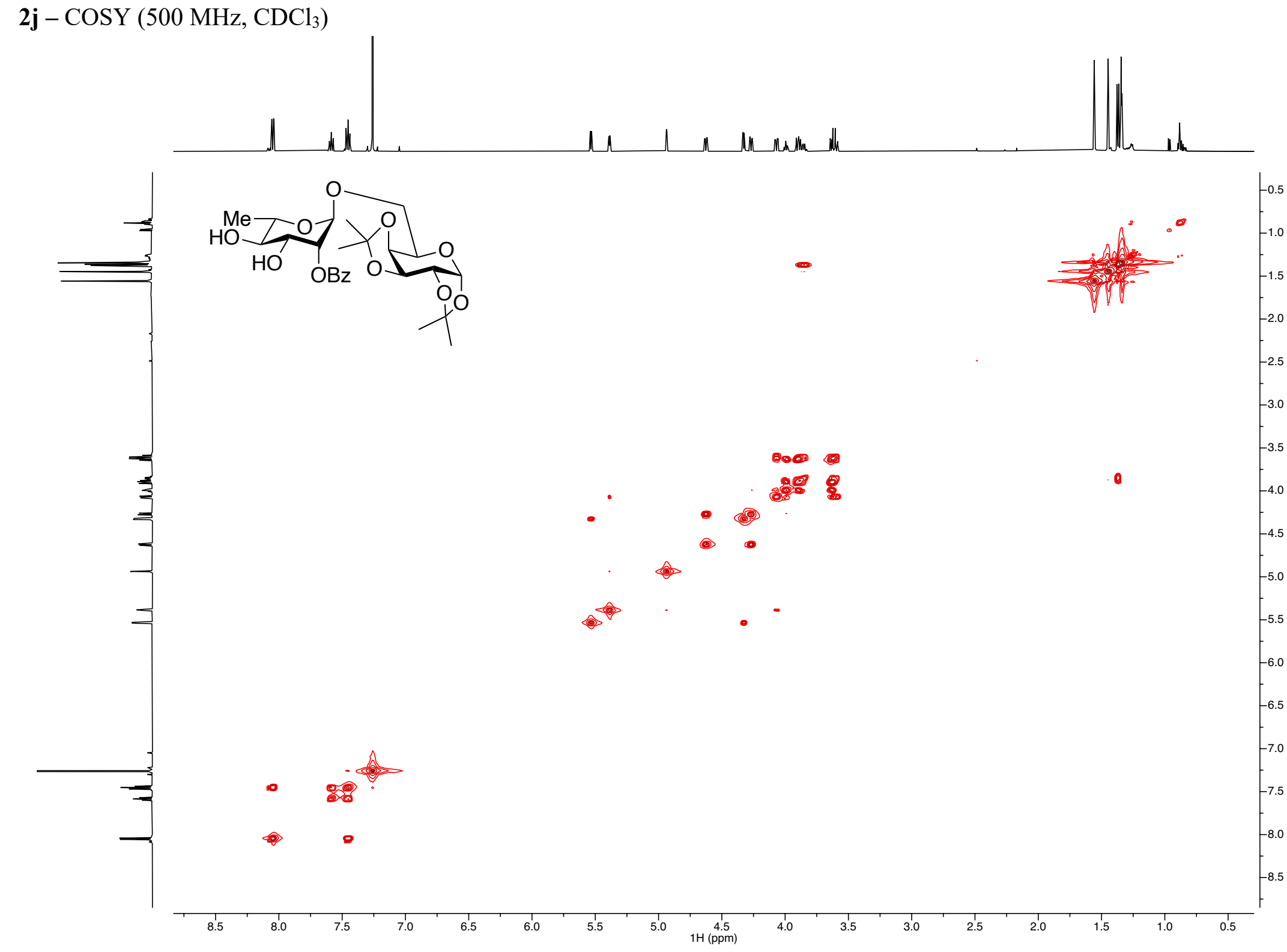

S163 
2k - Methyl 4- $O$-trimethylacetyl- $\alpha$-L-rhamnopyranoside ${ }^{1} \mathrm{H}$ NMR $\left(500 \mathrm{MHz}, \mathrm{CDCl}_{3}\right)$
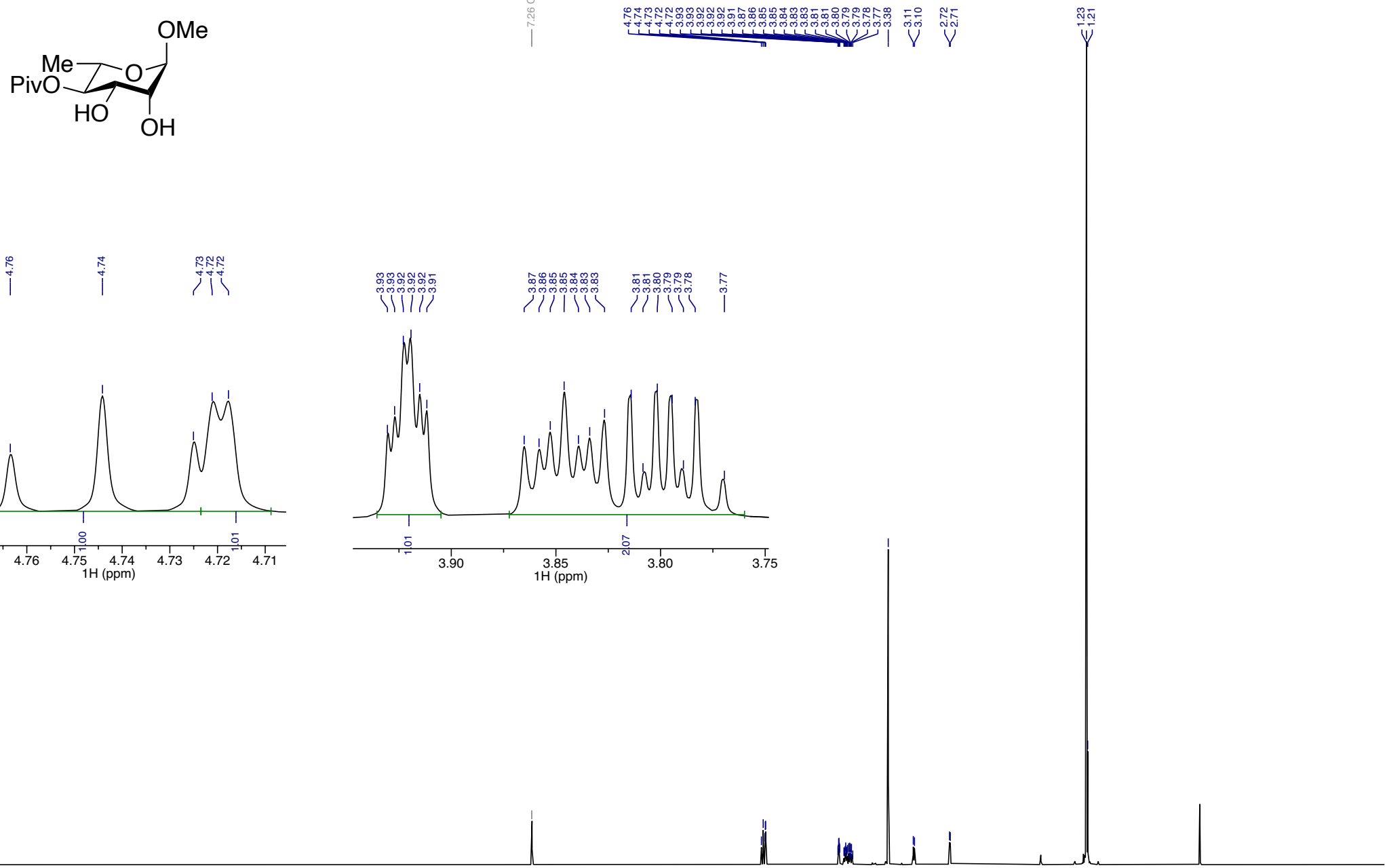

in

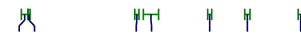

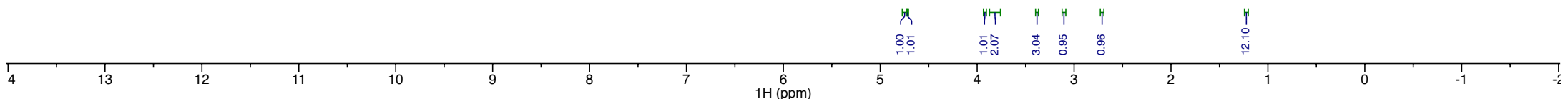


2k - ${ }^{13} \mathrm{C}$ NMR $\left(125 \mathrm{MHz}, \mathrm{CDCl}_{3}\right)$
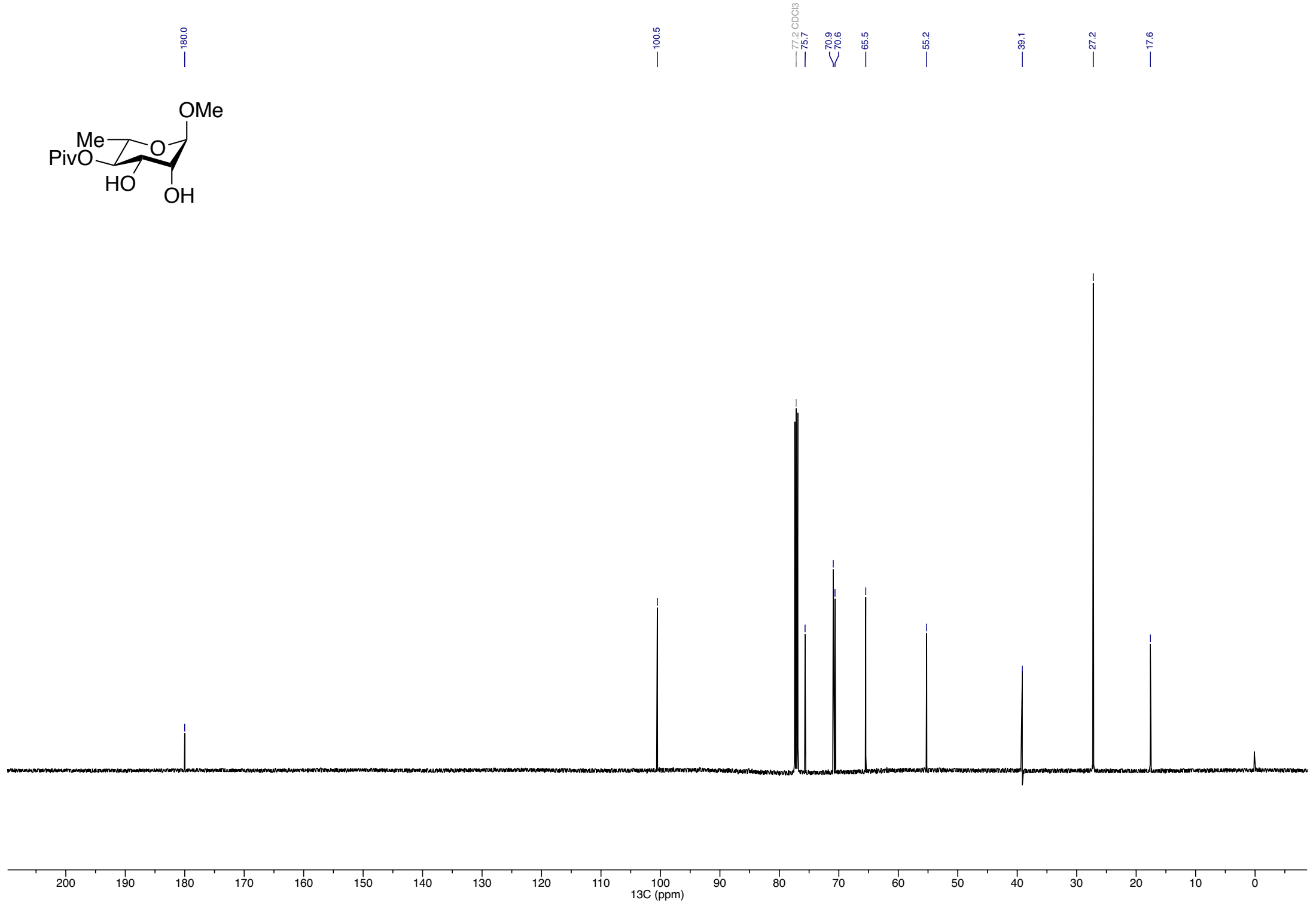

80
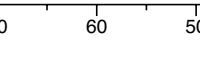

,

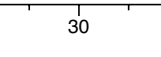


2k - COSY (400 MHz, $\left.\mathrm{CDCl}_{3}\right)$

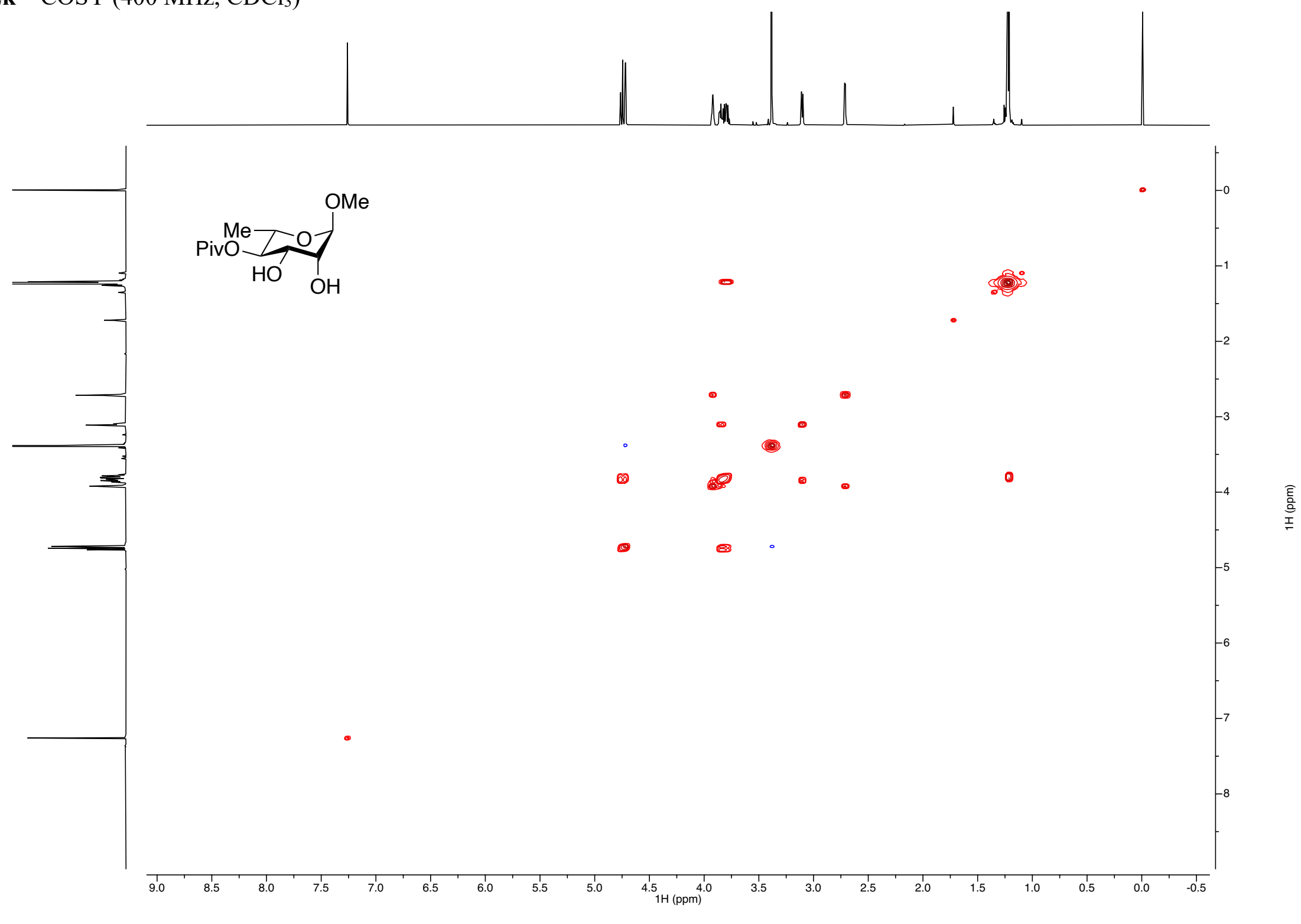




\section{2l - Methyl 2-O-trimethylacteyl- $\beta$-D-glucopyranoside}

${ }^{1} \mathrm{H} \mathrm{NMR}\left(500 \mathrm{MHz}, \mathrm{CDCl}_{3}\right)$
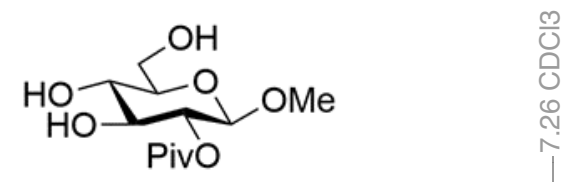

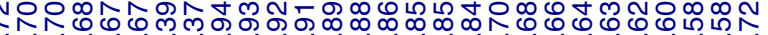

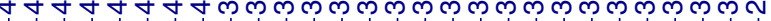
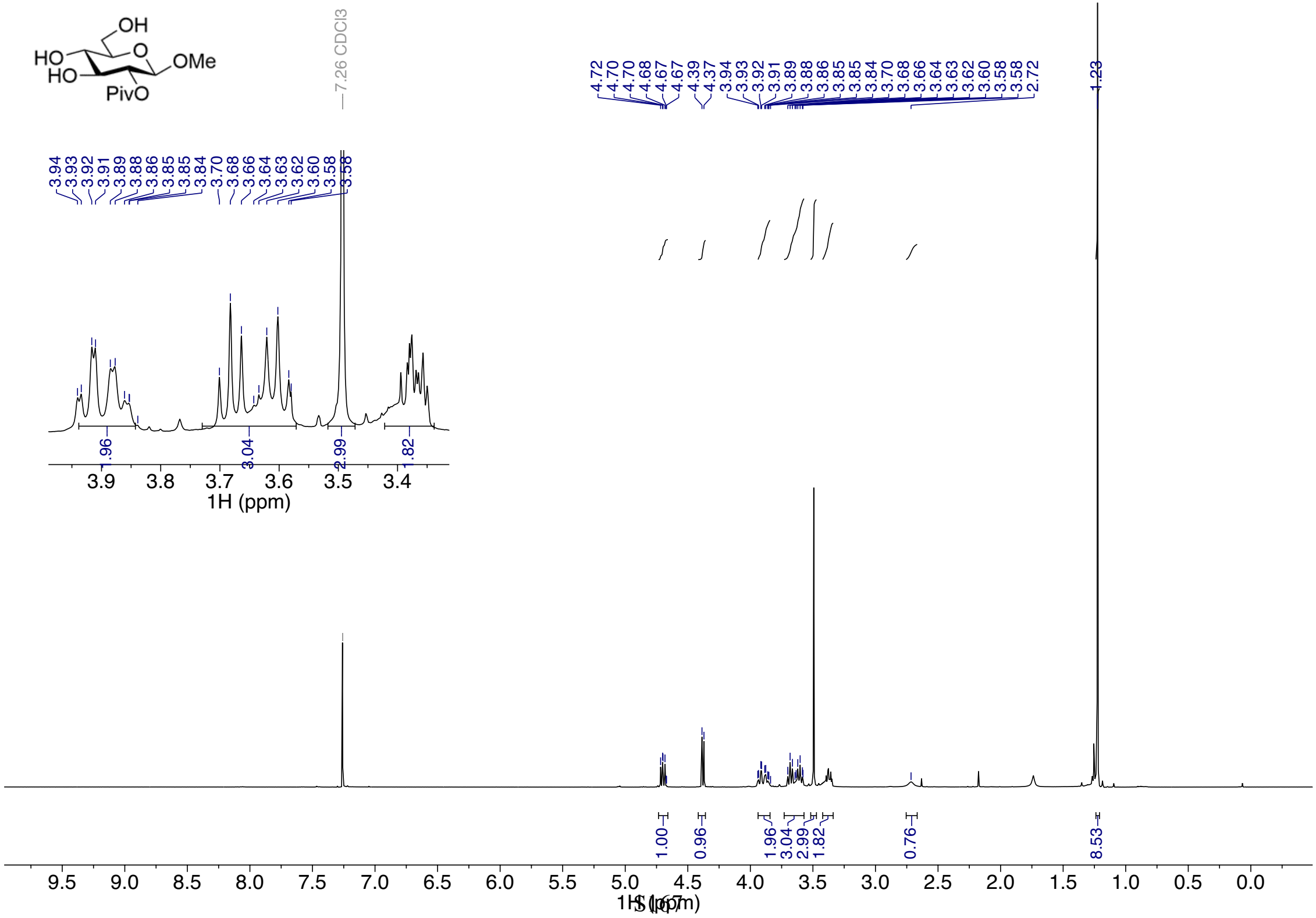
$2 \mathbf{l}-{ }^{13} \mathrm{C} \mathrm{NMR}\left(125 \mathrm{MHz}, \mathrm{CDCl}_{3}\right)$

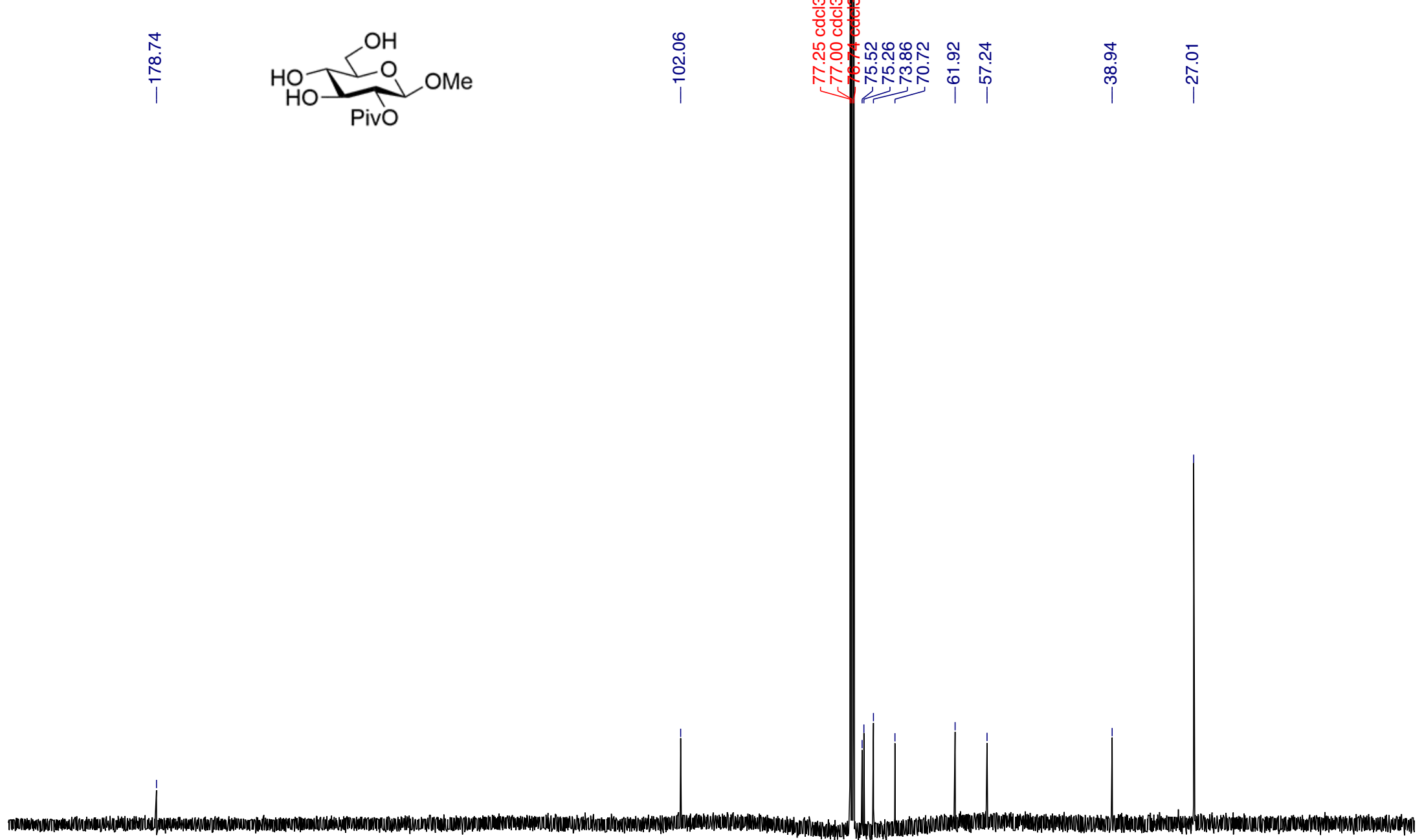

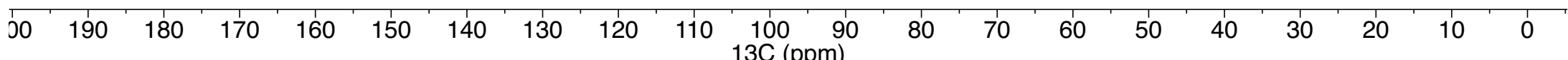




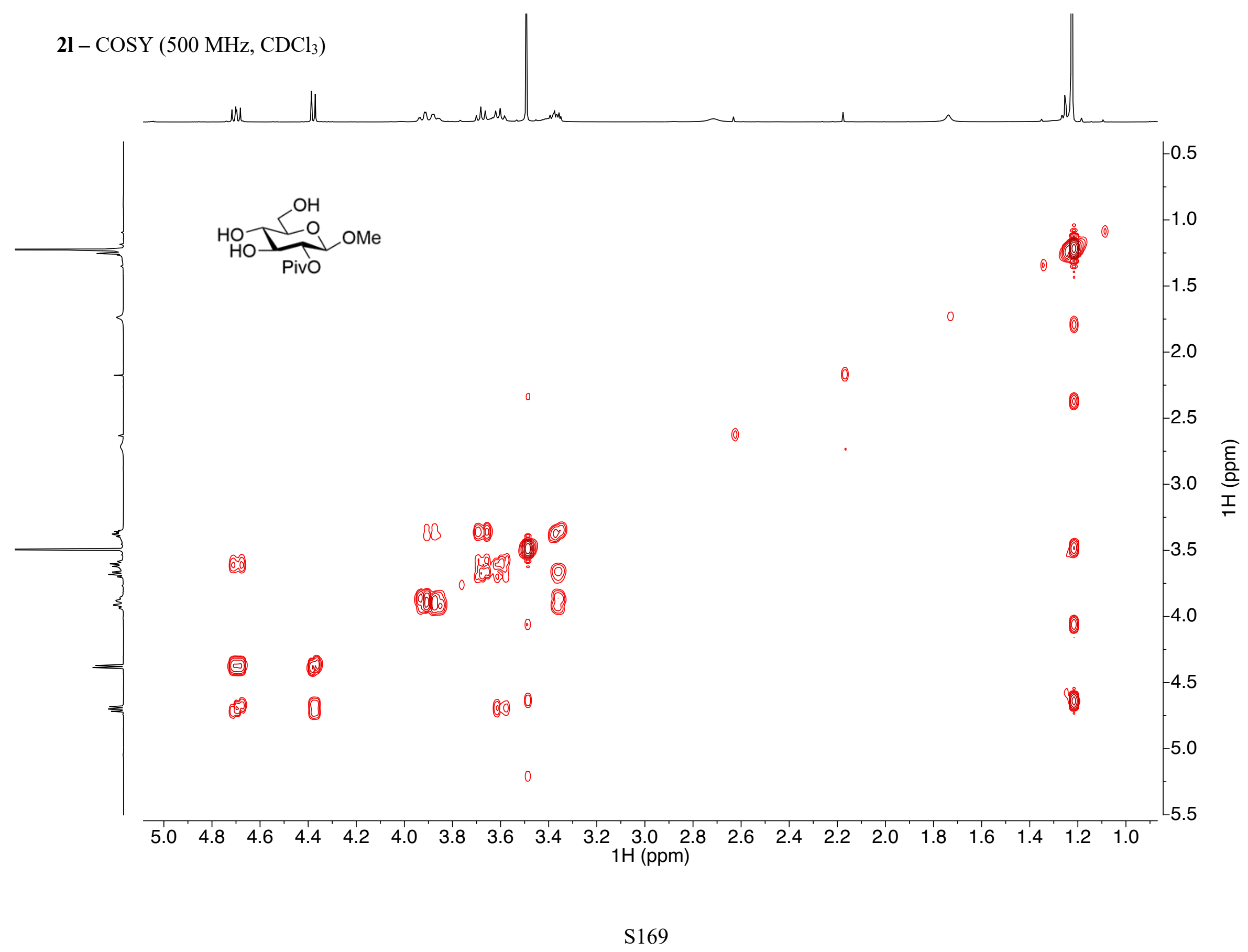




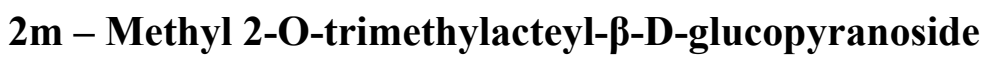

${ }^{1} \mathrm{H}$ NMR $\left(500 \mathrm{MHz}, \mathrm{CDCl}_{3}\right)$
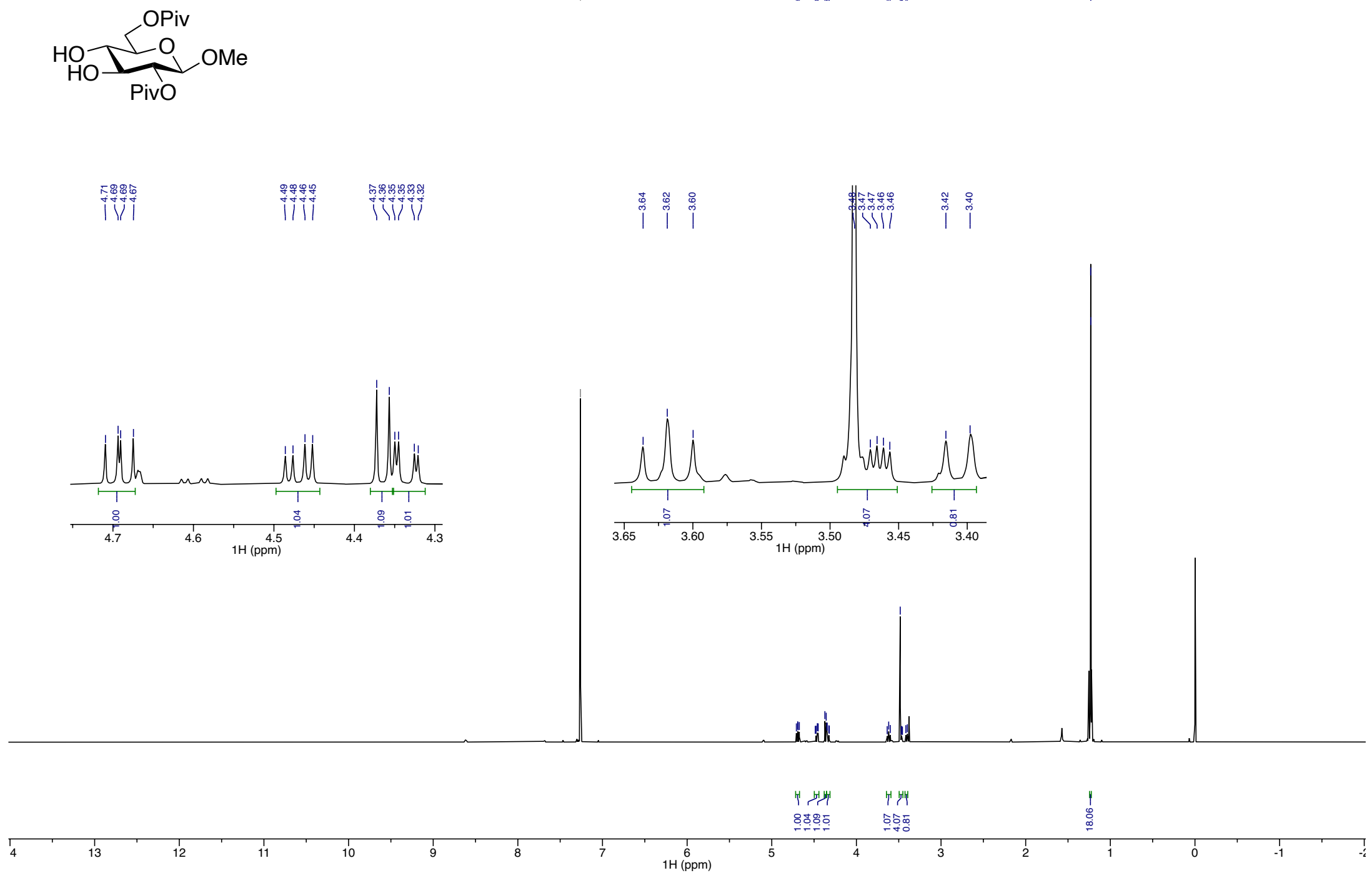
$\mathbf{2 m}-{ }^{13} \mathrm{C}$ NMR $\left(125 \mathrm{MHz}, \mathrm{CDCl}_{3}\right)$

PivO
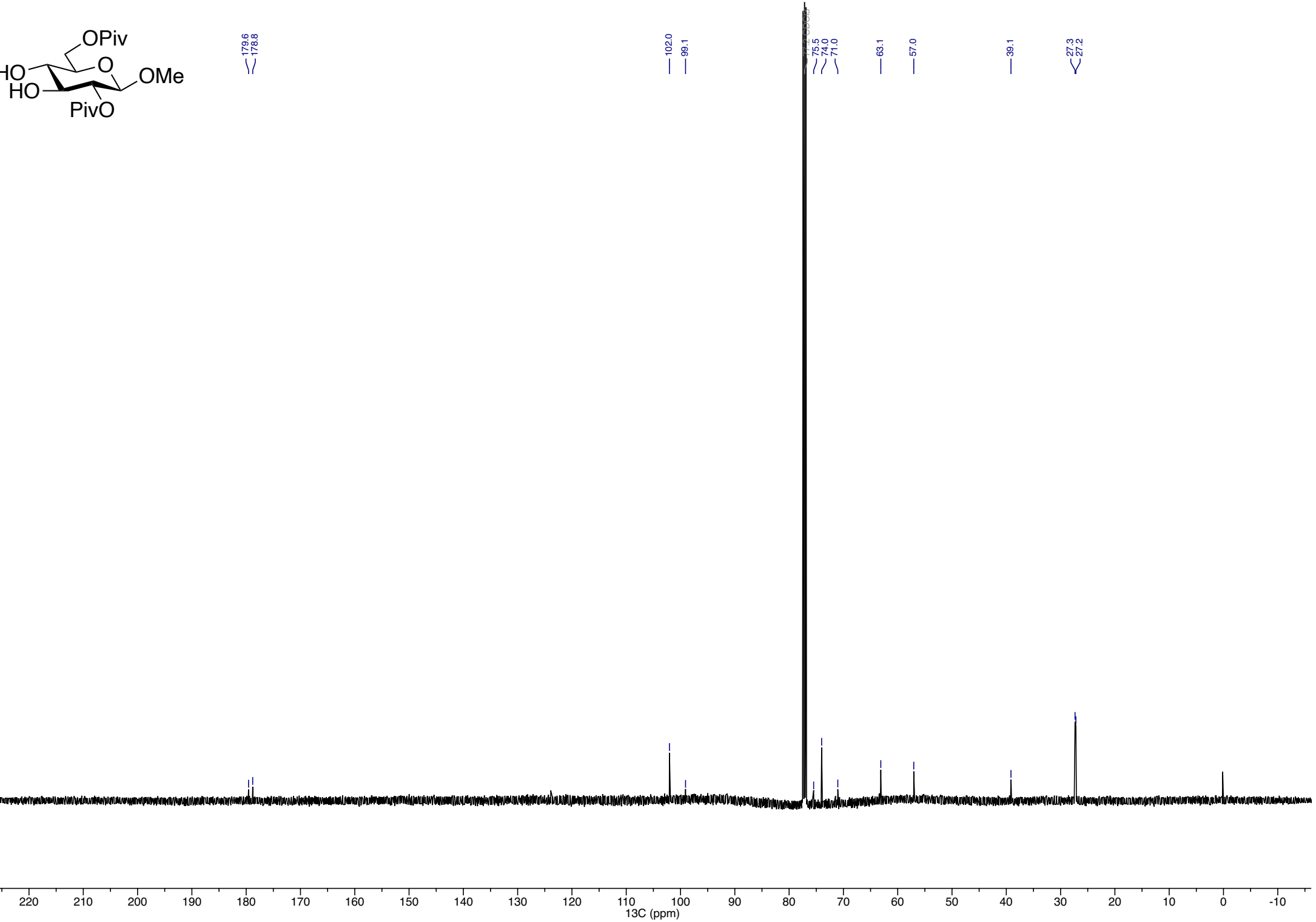
$\mathbf{2 m}-\operatorname{COSY}\left(500 \mathrm{MHz}, \mathrm{CDCl}_{3}\right)$

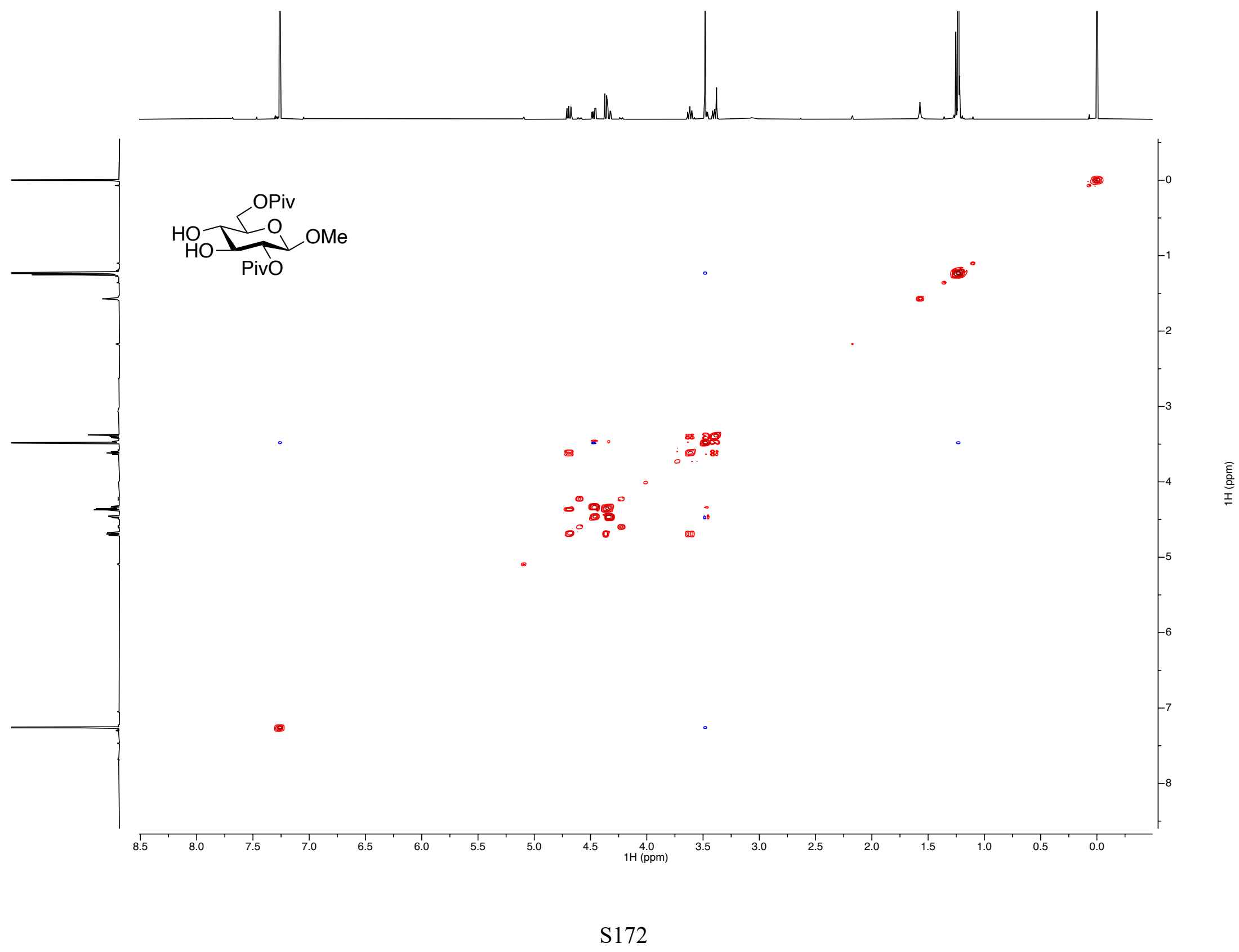


4a - Methyl 2-deoxy- $\alpha$-D-erythro-hexopyranoside-3-ulose

${ }^{1} \mathrm{H} \mathrm{NMR}\left(500 \mathrm{MHz}, \mathrm{CDCl}_{3}\right)$

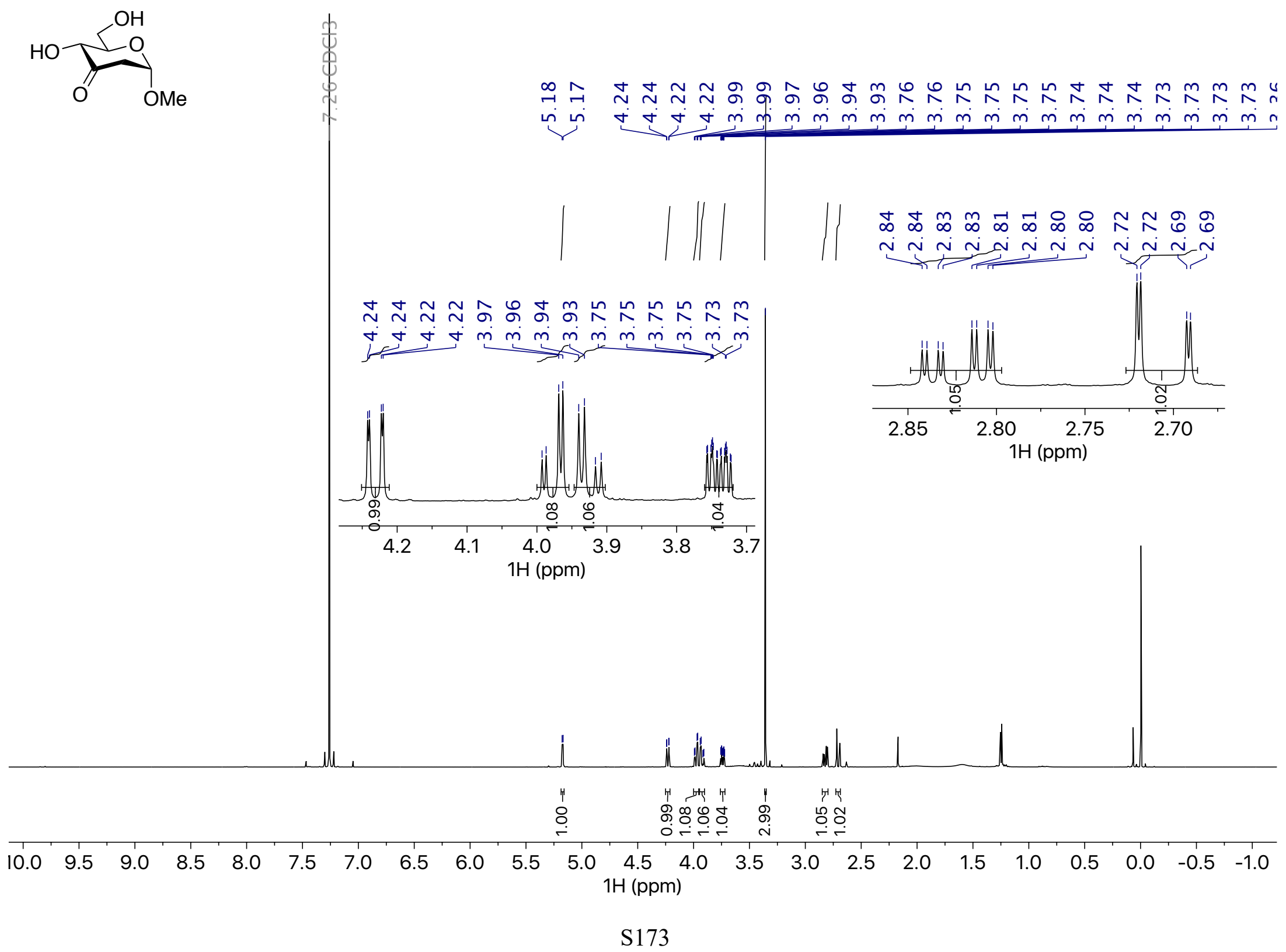


4a $-{ }^{13} \mathrm{C}$ NMR $\left(125 \mathrm{MHz}, \mathrm{CDCl}_{3}\right)$
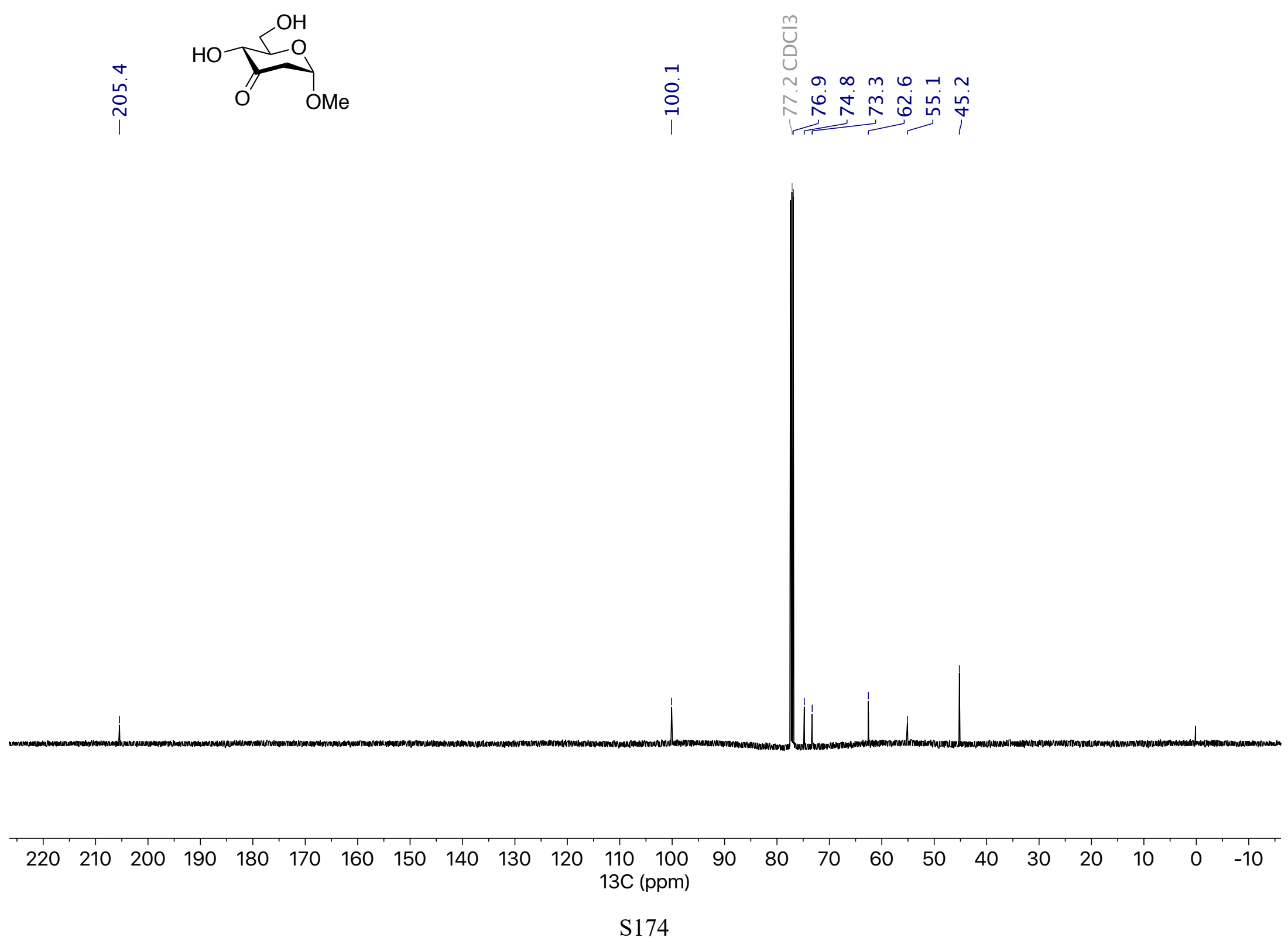


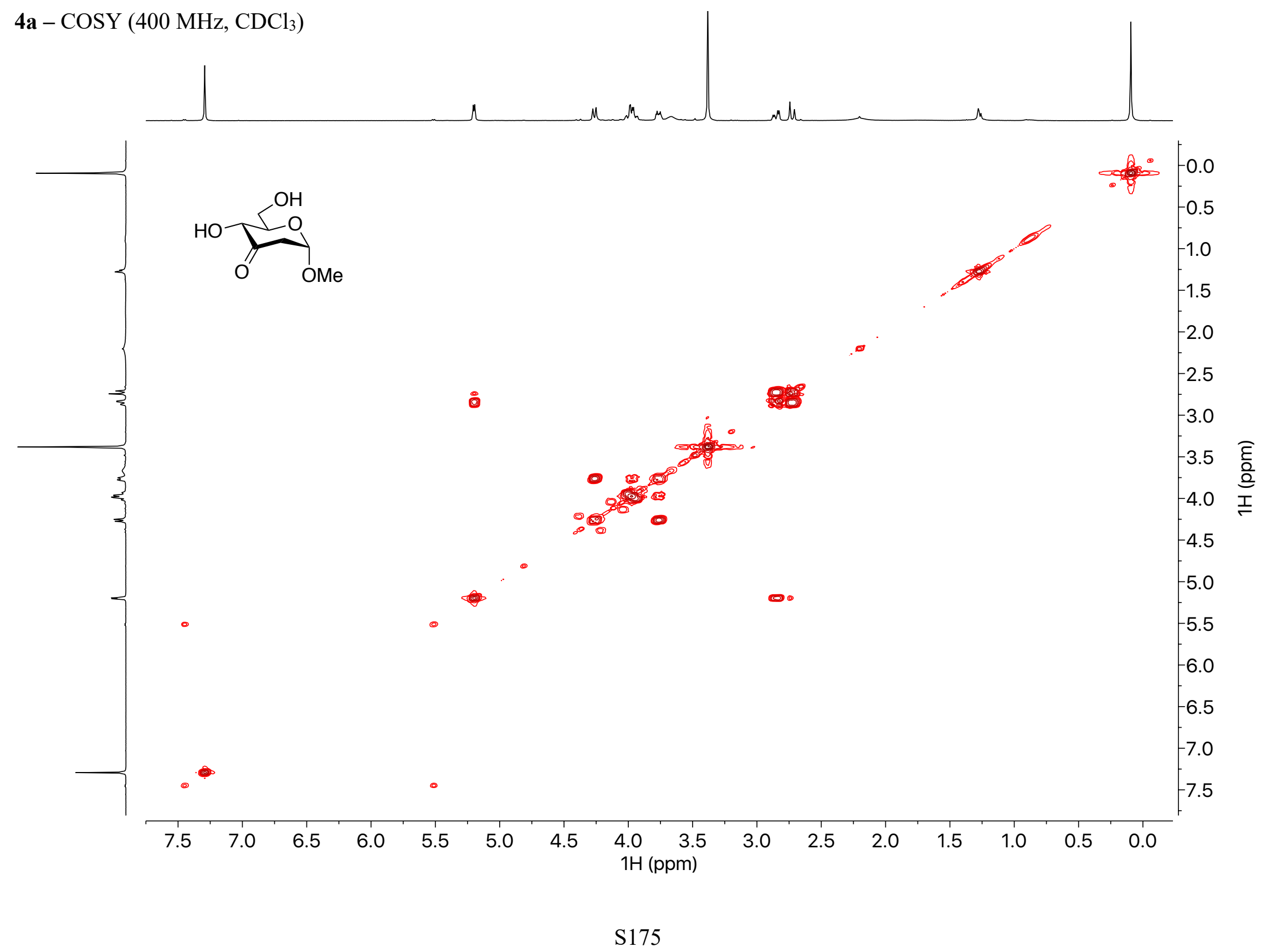


4b - Methyl 2-deoxy-6-O-(tert-butyldimethylsilyl)- $\alpha$-D-erythro-hexopyranoside-3-ulose

${ }^{1} \mathrm{H}$ NMR $\left(500 \mathrm{MHz}, \mathrm{CDCl}_{3}\right)$

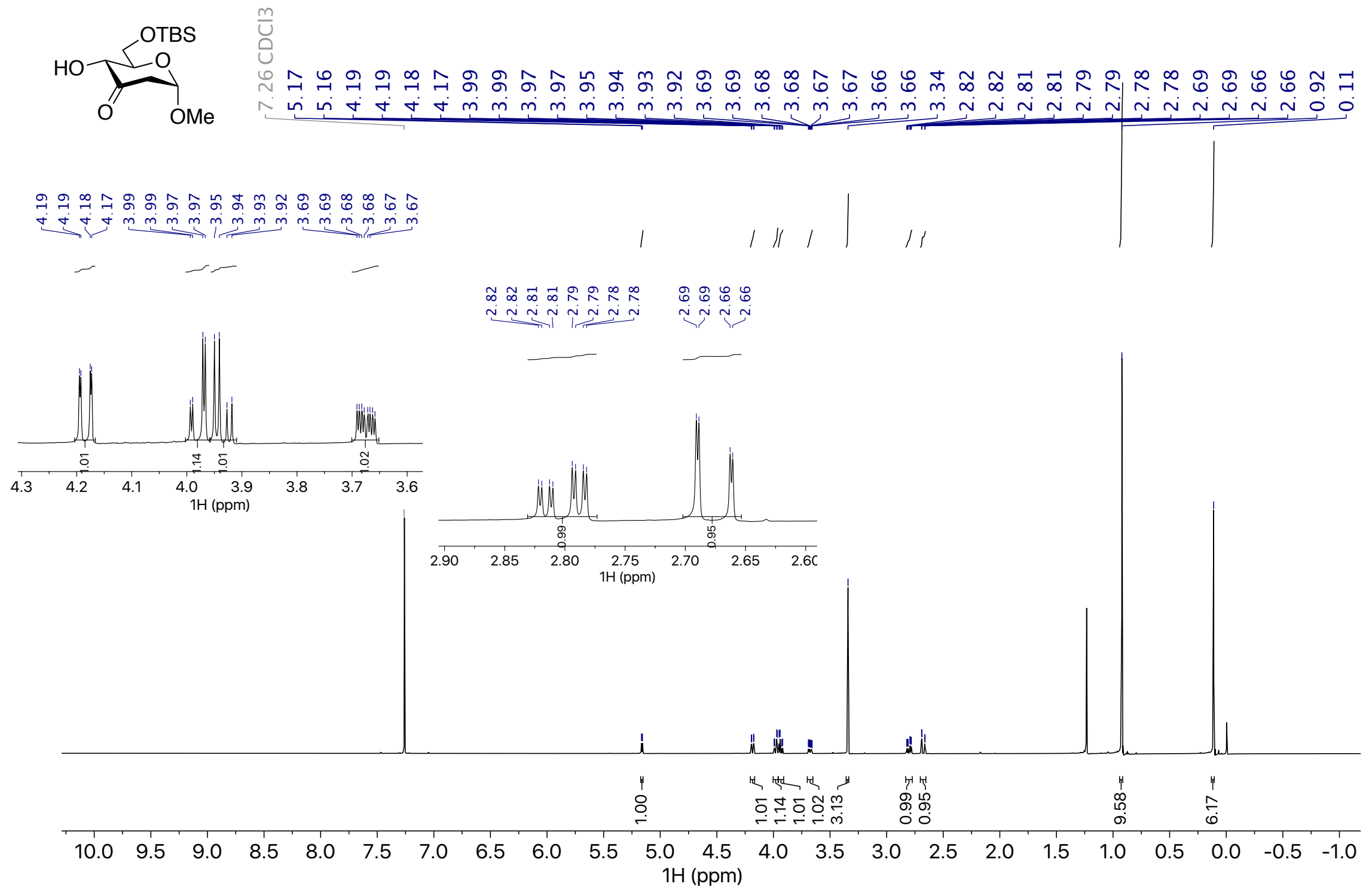


4b $-{ }^{13} \mathrm{C}$ NMR $\left(125 \mathrm{MHz}, \mathrm{CDCl}_{3}\right)$
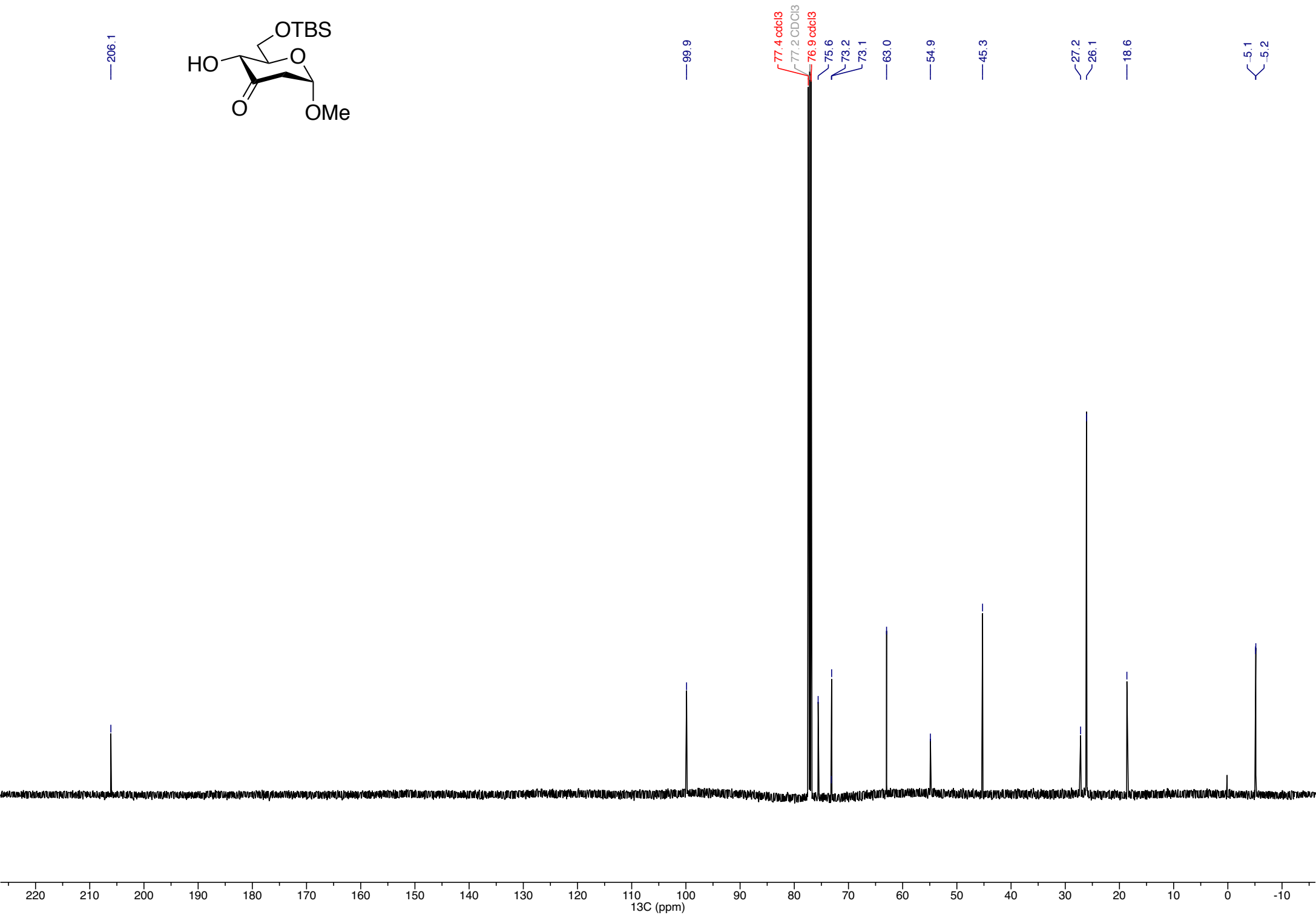


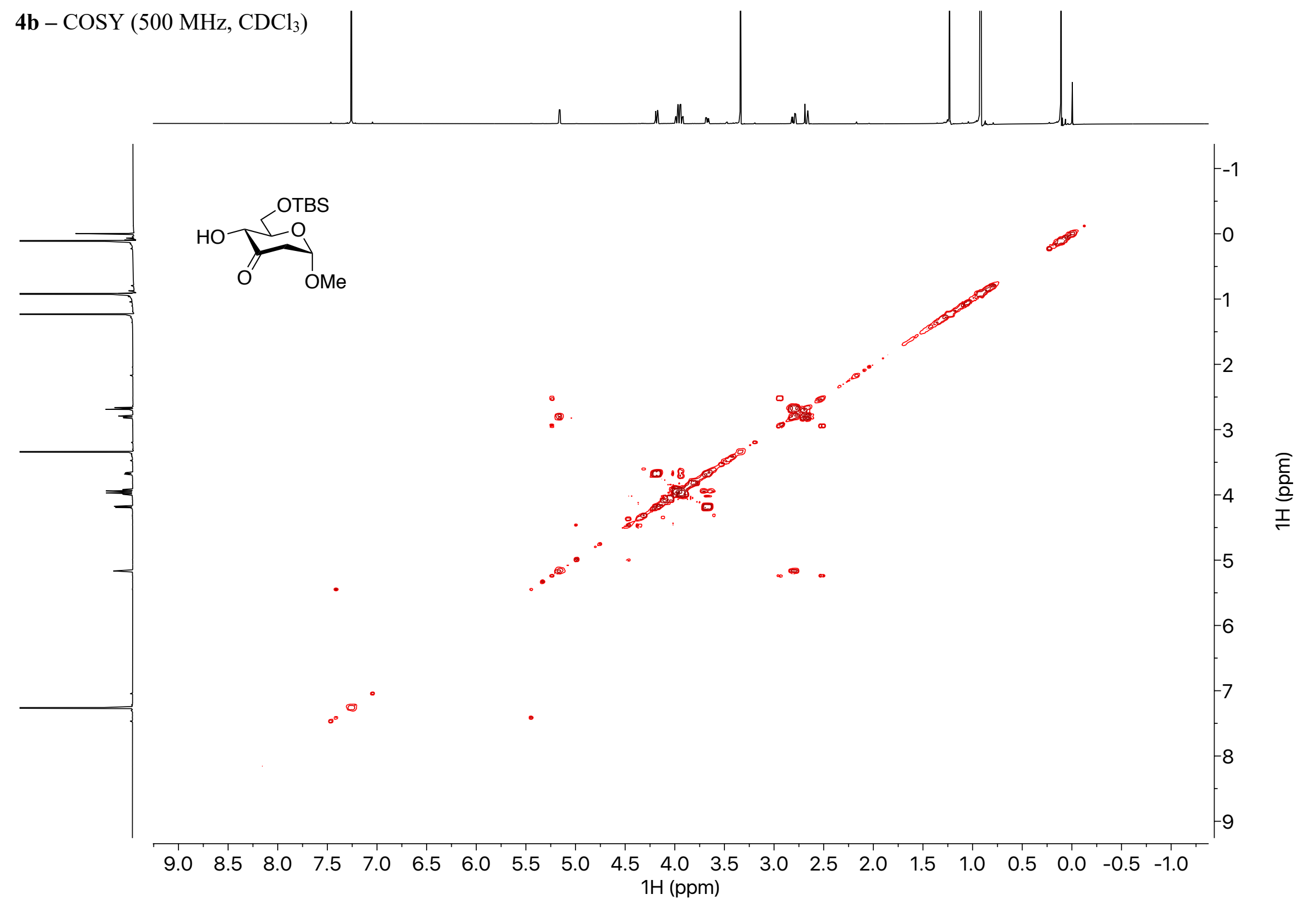


4c - Methyl 2-deoxy-6-O-trimethylacetyl- $\alpha$-D-erythro-hexopyranoside-3-ulose

${ }^{1} \mathrm{H}$ NMR $\left(500 \mathrm{MHz}, \mathrm{CDCl}_{3}\right)$

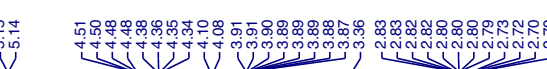

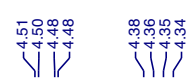

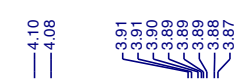

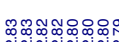

บับบบับกับ

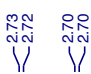
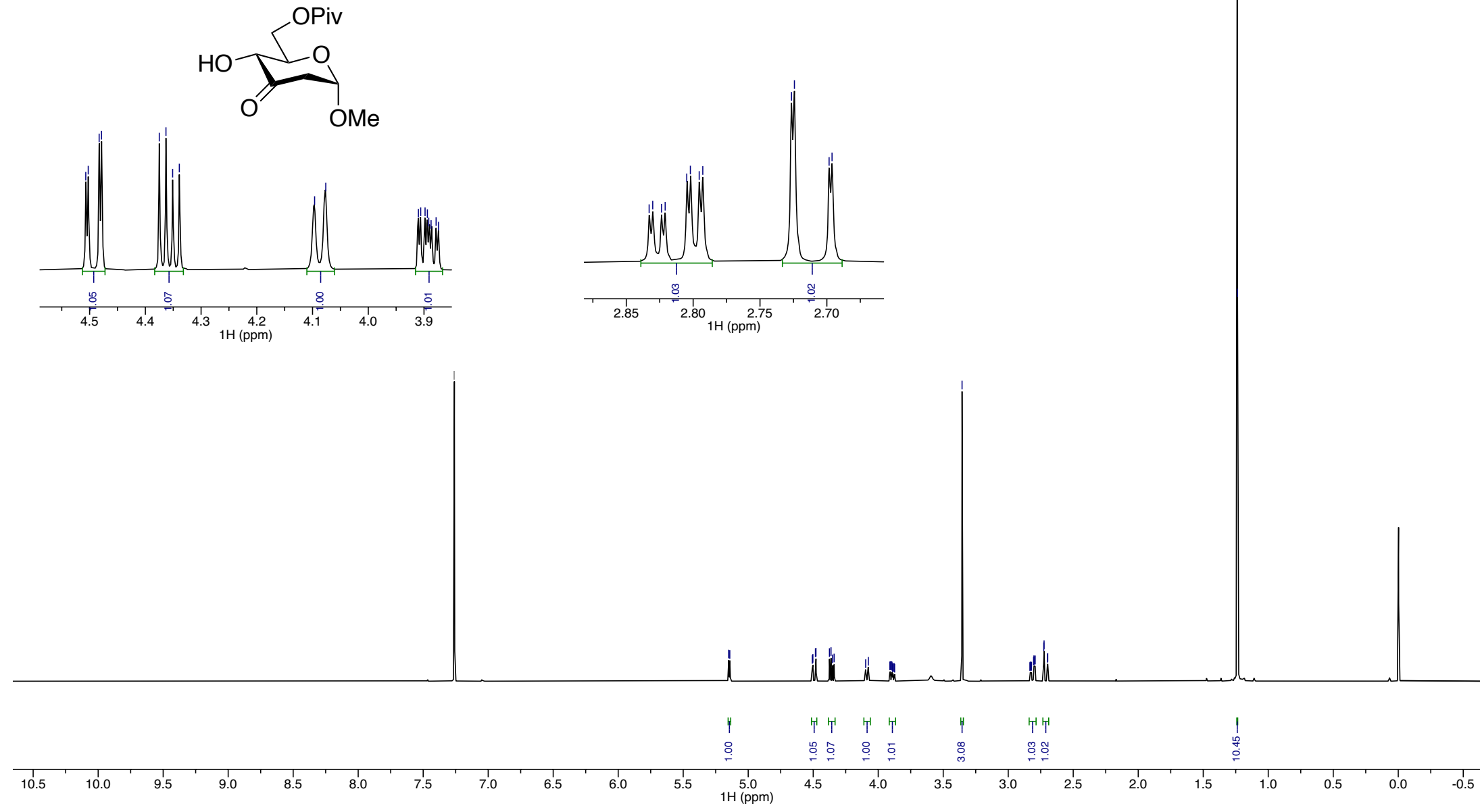
$4 \mathbf{c}-{ }^{13} \mathrm{C}$ NMR $\left(126 \mathrm{MHz}, \mathrm{CDCl}_{3}\right)$

总 $\stackrel{\substack{0 \\ \hdashline}}{i}$
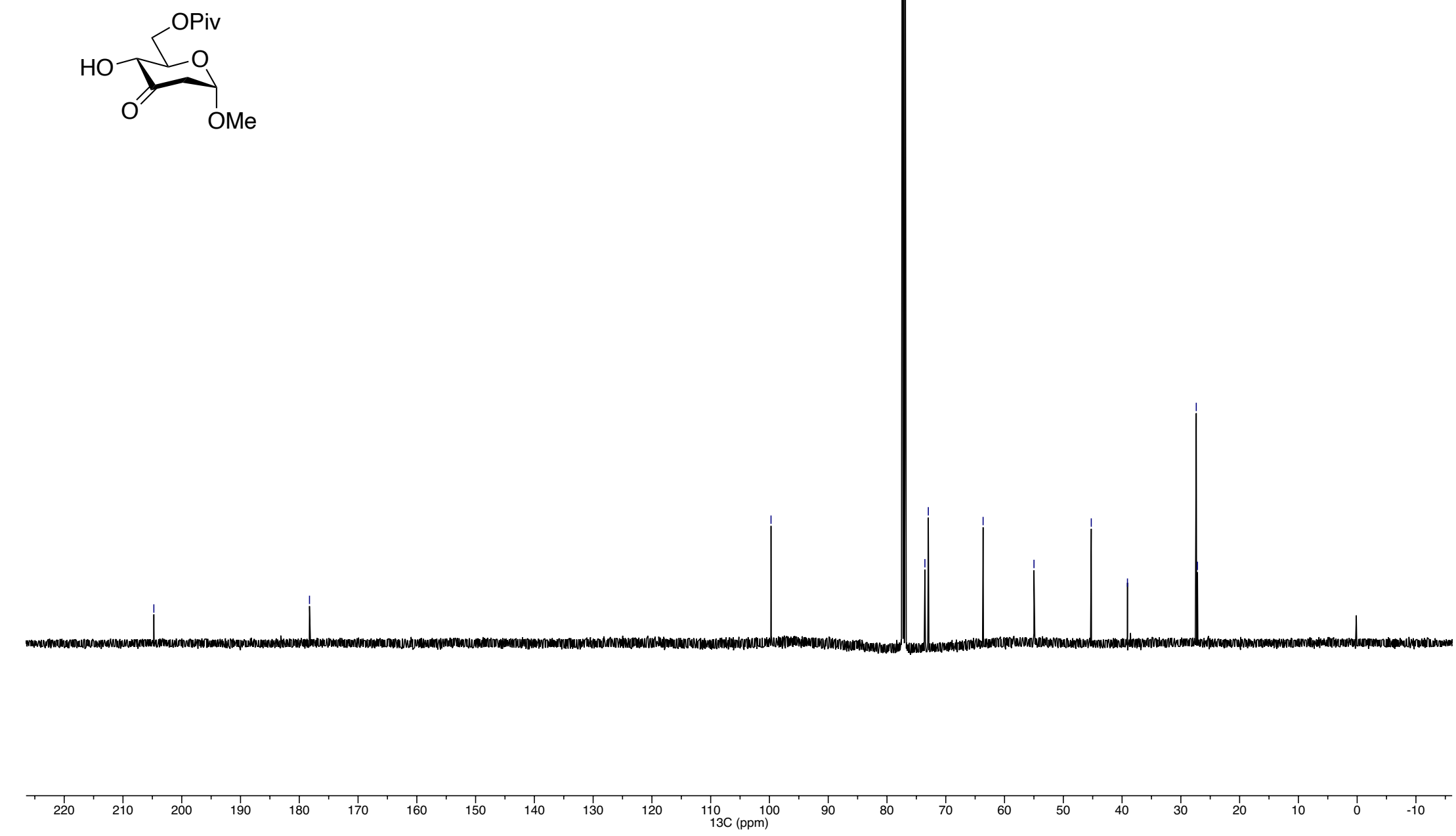

S180 
4c-COSY $\left(500 \mathrm{MHz}, \mathrm{CDCl}_{3}\right)$

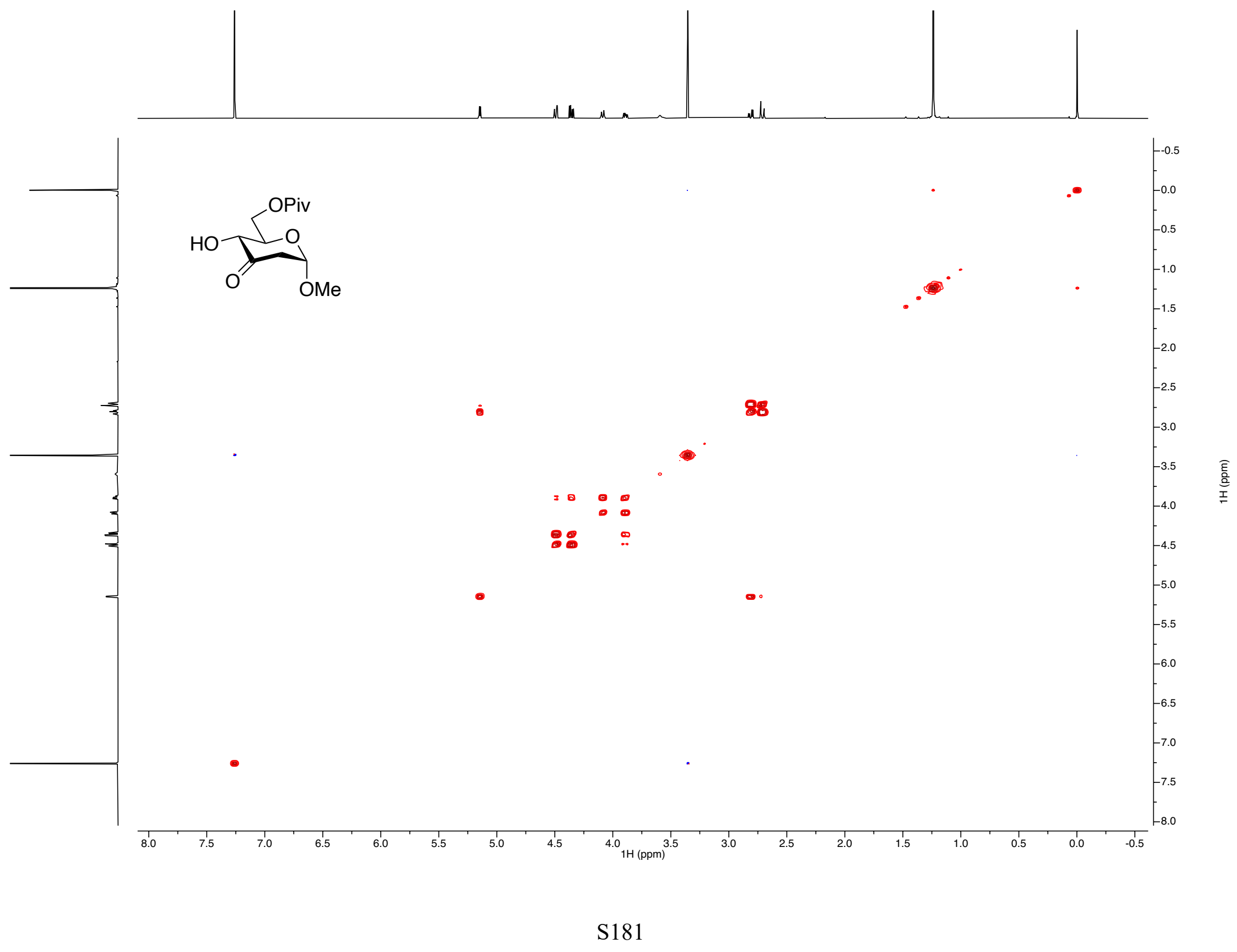


4d - Methyl 6-O-(2',3',4',6'-tetra-O-acetyl- $\beta$-D-galactopyranosyl)- $\alpha$-D-erythro-hexopyranoside-3-ulose ${ }^{1} \mathrm{H} \mathrm{NMR}\left(500 \mathrm{MHz}, \mathrm{CDCl}_{3}\right)$

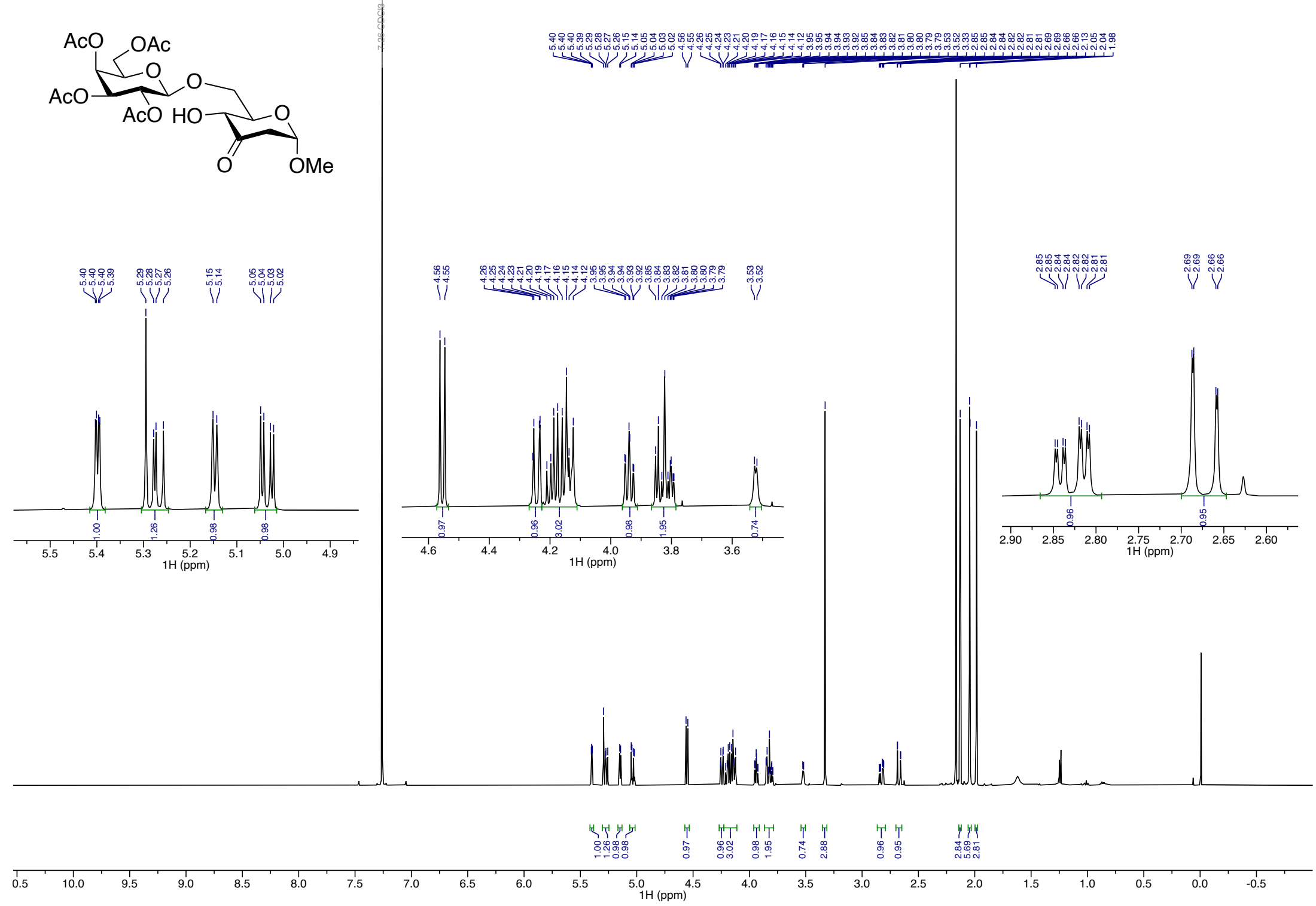


4d $-{ }^{13} \mathrm{C}$ NMR $\left(126 \mathrm{MHz}, \mathrm{CDCl}_{3}\right)$

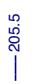

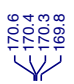
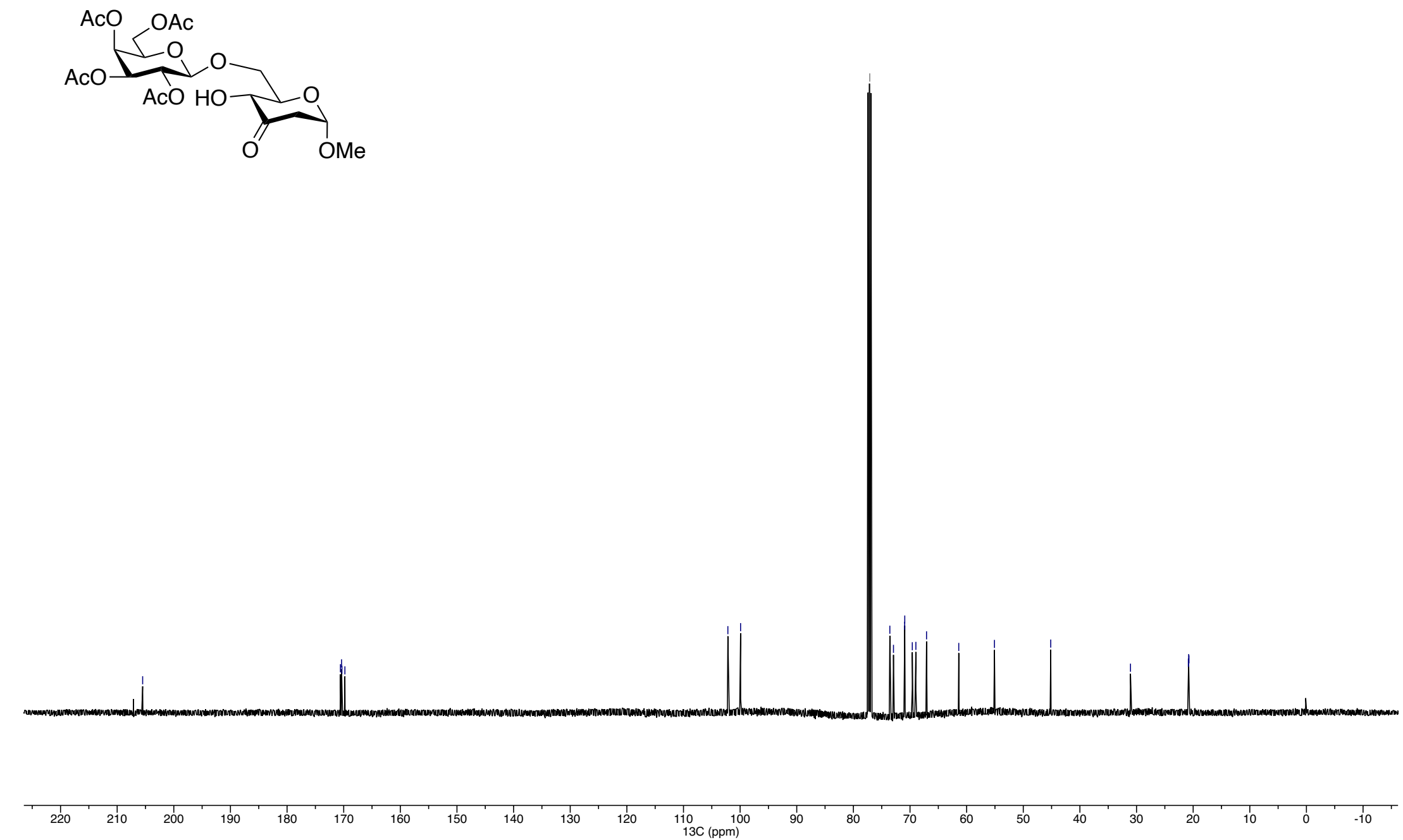
4d -COSY (500 MHz, $\left.\mathrm{CDCl}_{3}\right)$

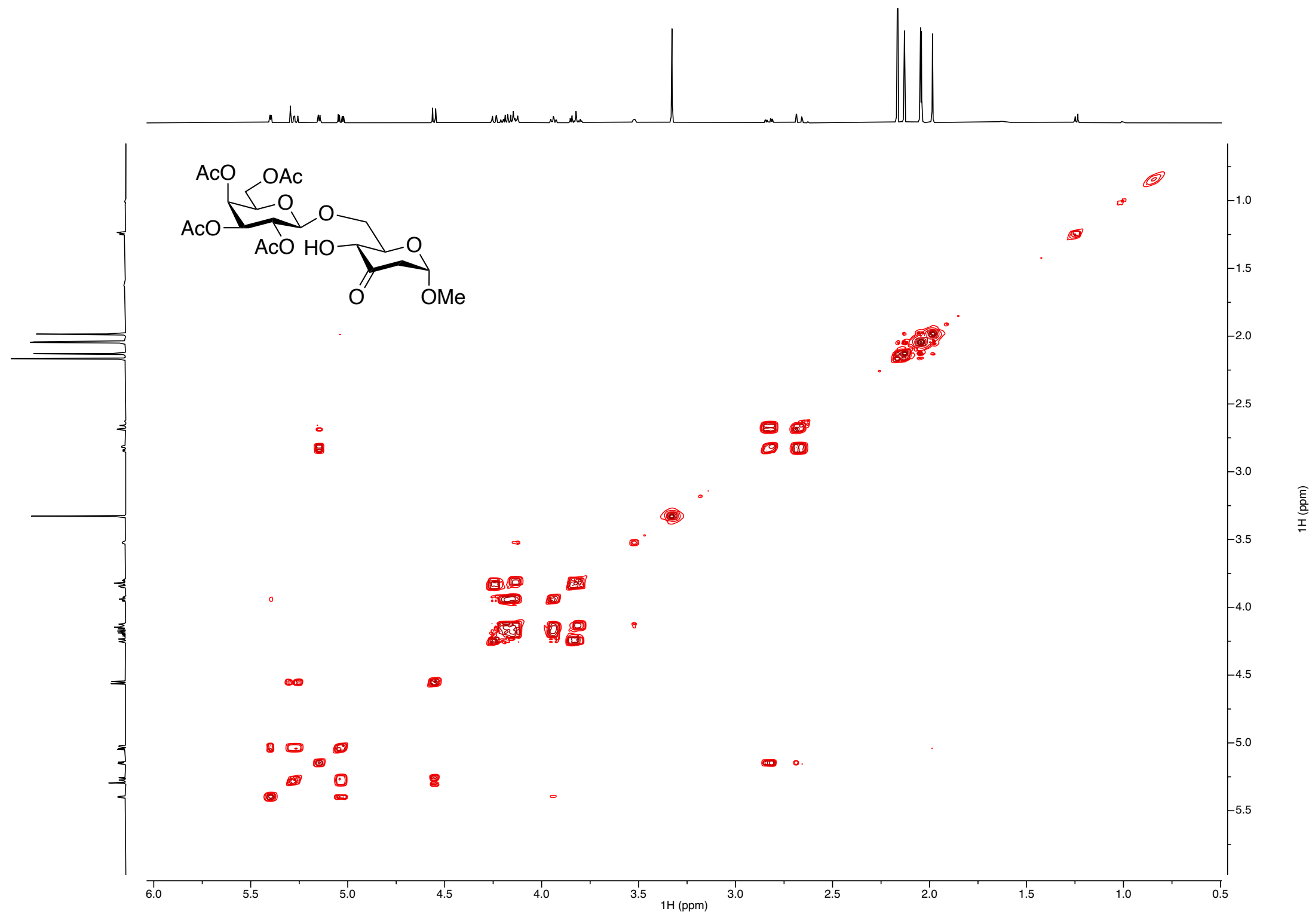


4e - Methyl 4-deoxy-6-O-(tert-butyldimethylsilyl)- $\alpha$-D-erythro-hexopyranoside-3-ulose

${ }^{1} \mathrm{H}$ NMR $\left(500 \mathrm{MHz}, \mathrm{CDCl}_{3}\right)$

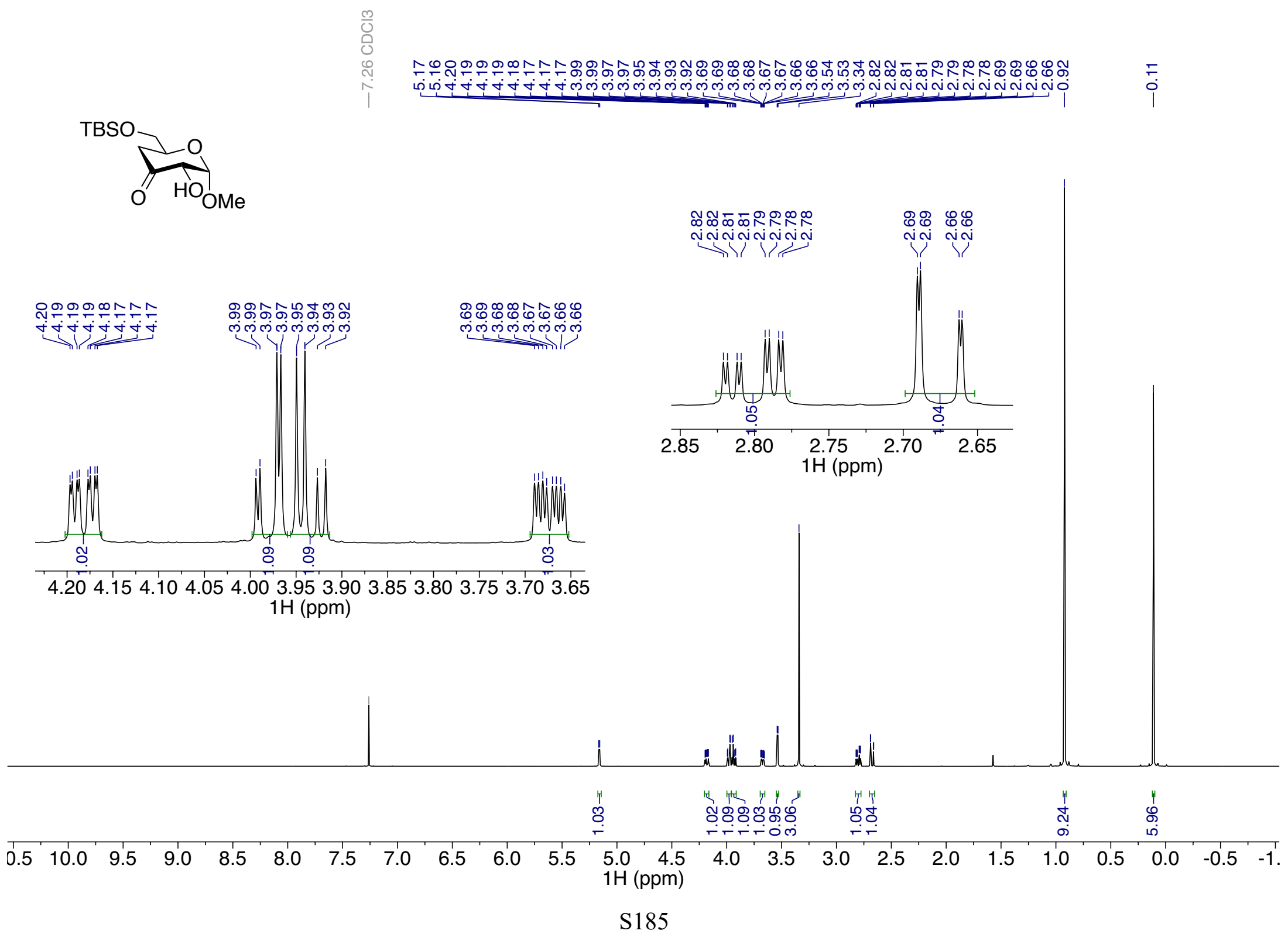


$4 \mathbf{e}-{ }^{13} \mathrm{C}$ NMR $\left(126 \mathrm{MHz}, \mathrm{CDCl}_{3}\right)$

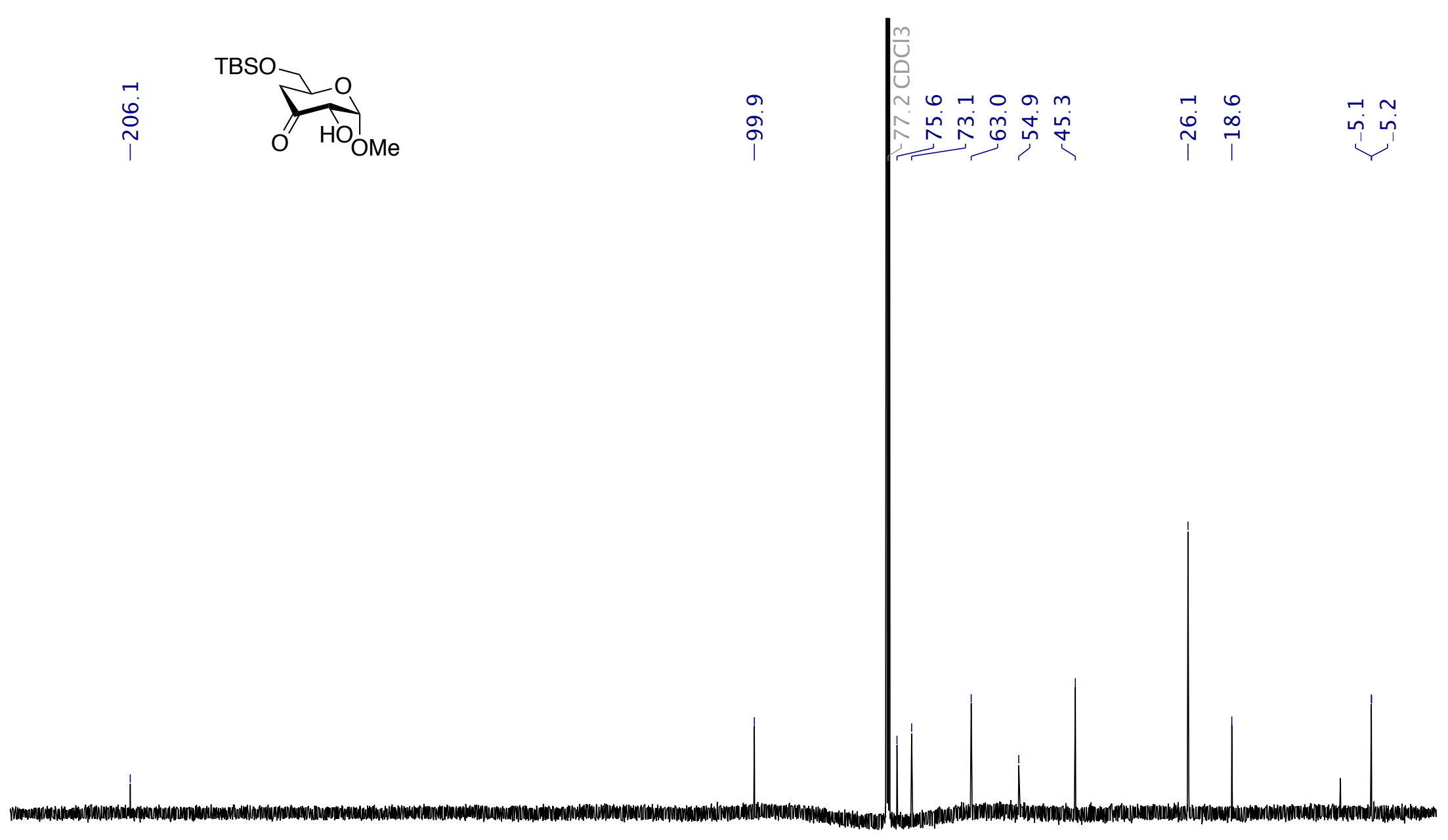

$\begin{array}{rlllllllllllllllllllllll}220 & 210 & 200 & 190 & 180 & 170 & 160 & 150 & 140 & 130 & 120 & 110 & 100 & 90 & 80 & 70 & 60 & 50 & 40 & 30 & 20 & 10 & 0 & -10\end{array}$


4e-COSY $\left(500 \mathrm{MHz}, \mathrm{CDCl}_{3}\right)$

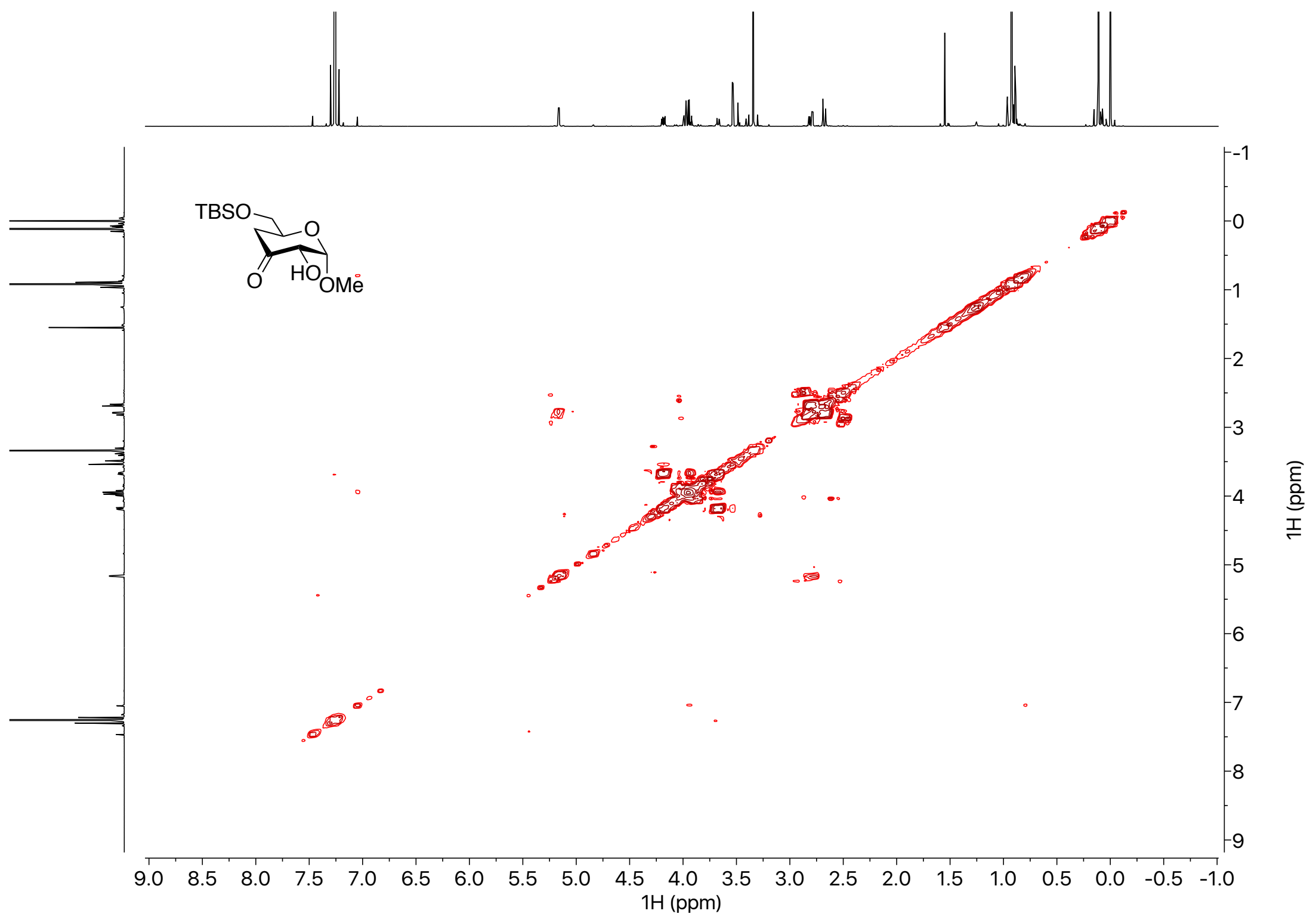


4f - Methyl 2,6-dideoxy- $\alpha$-D-erythro-hexopyranoside-3-ulose

${ }^{1} \mathrm{H} \mathrm{NMR}\left(500 \mathrm{MHz}, \mathrm{CDCl}_{3}\right)$

\section{บै}

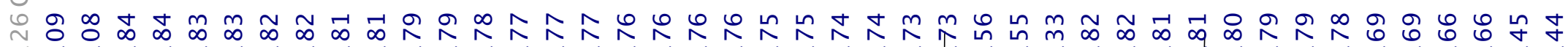

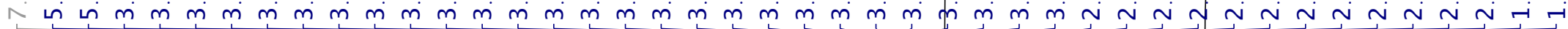
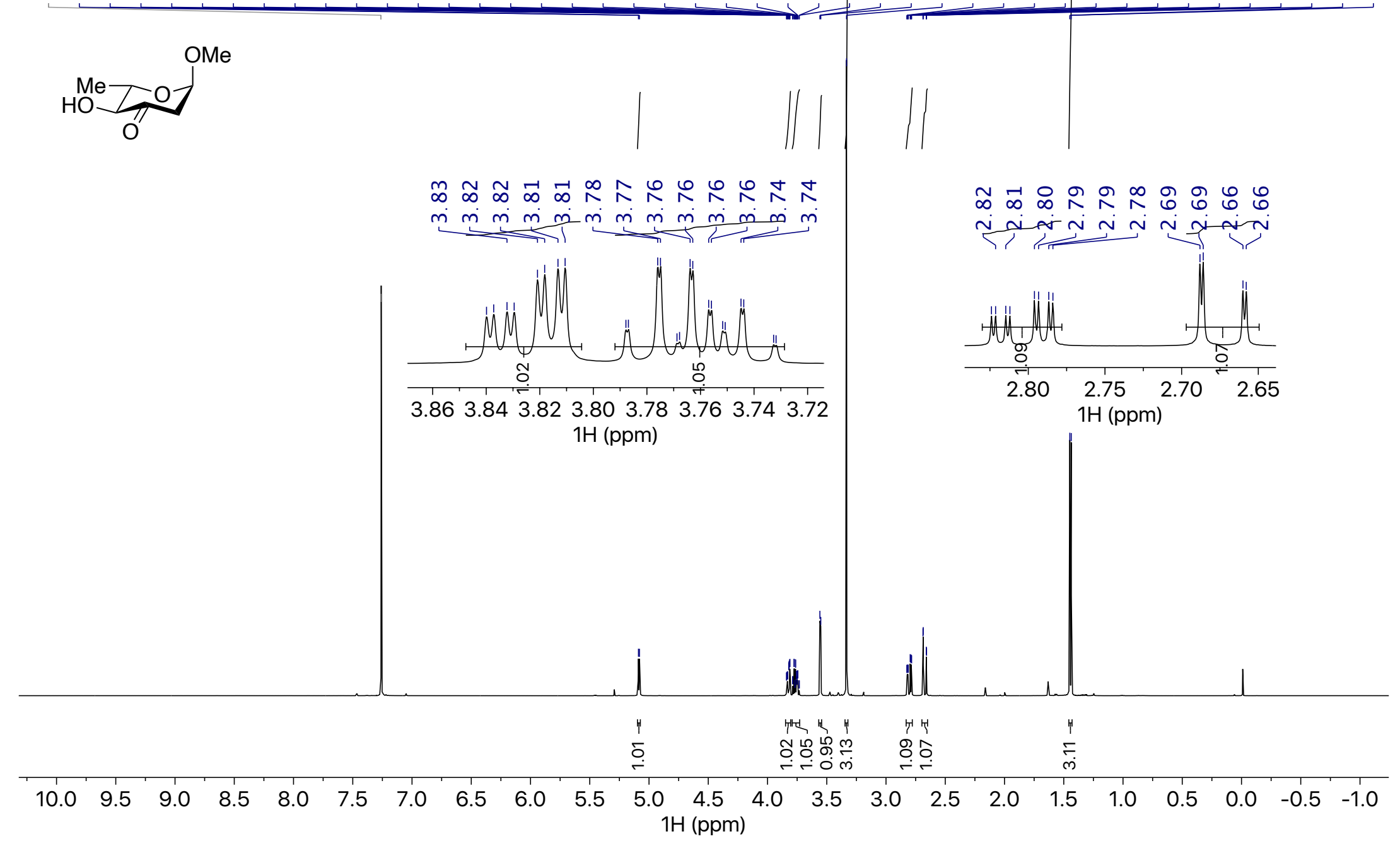

S188 
4f $-{ }^{13} \mathrm{C} \mathrm{NMR}\left(126 \mathrm{MHz}, \mathrm{CDCl}_{3}\right)$
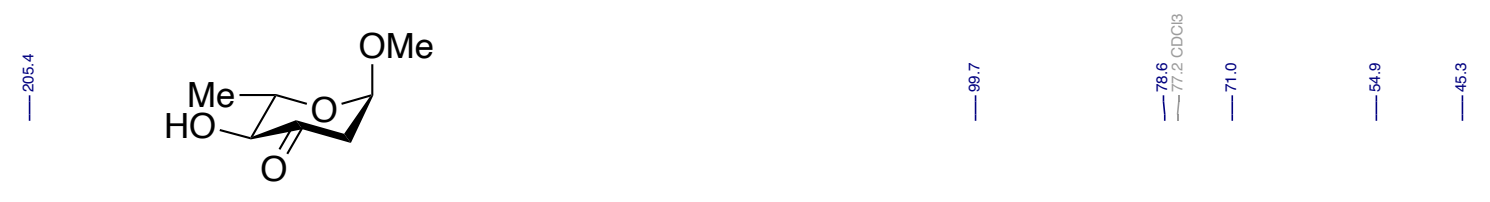

$\stackrel{\stackrel{\infty}{\infty}}{\Gamma}$

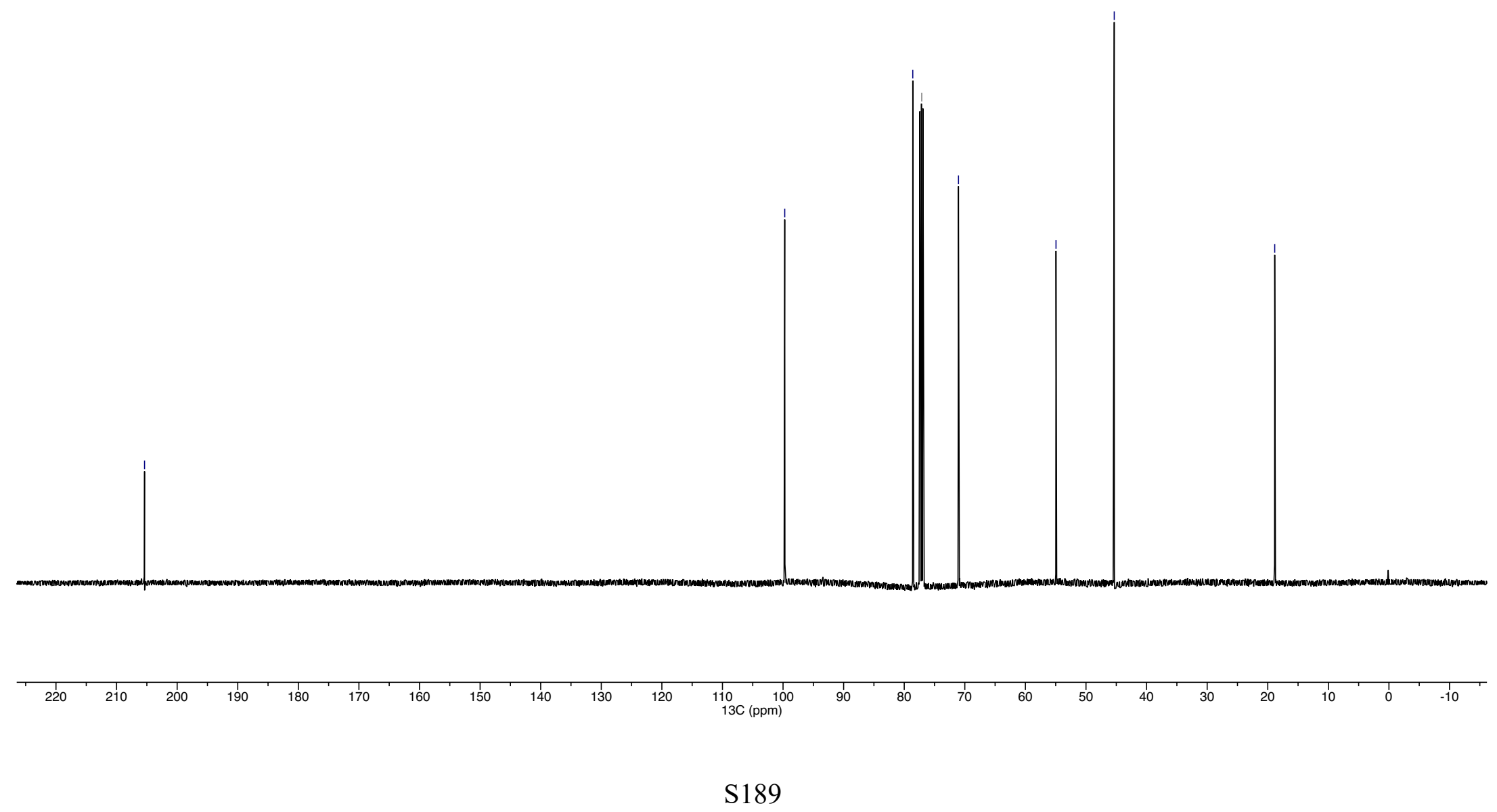




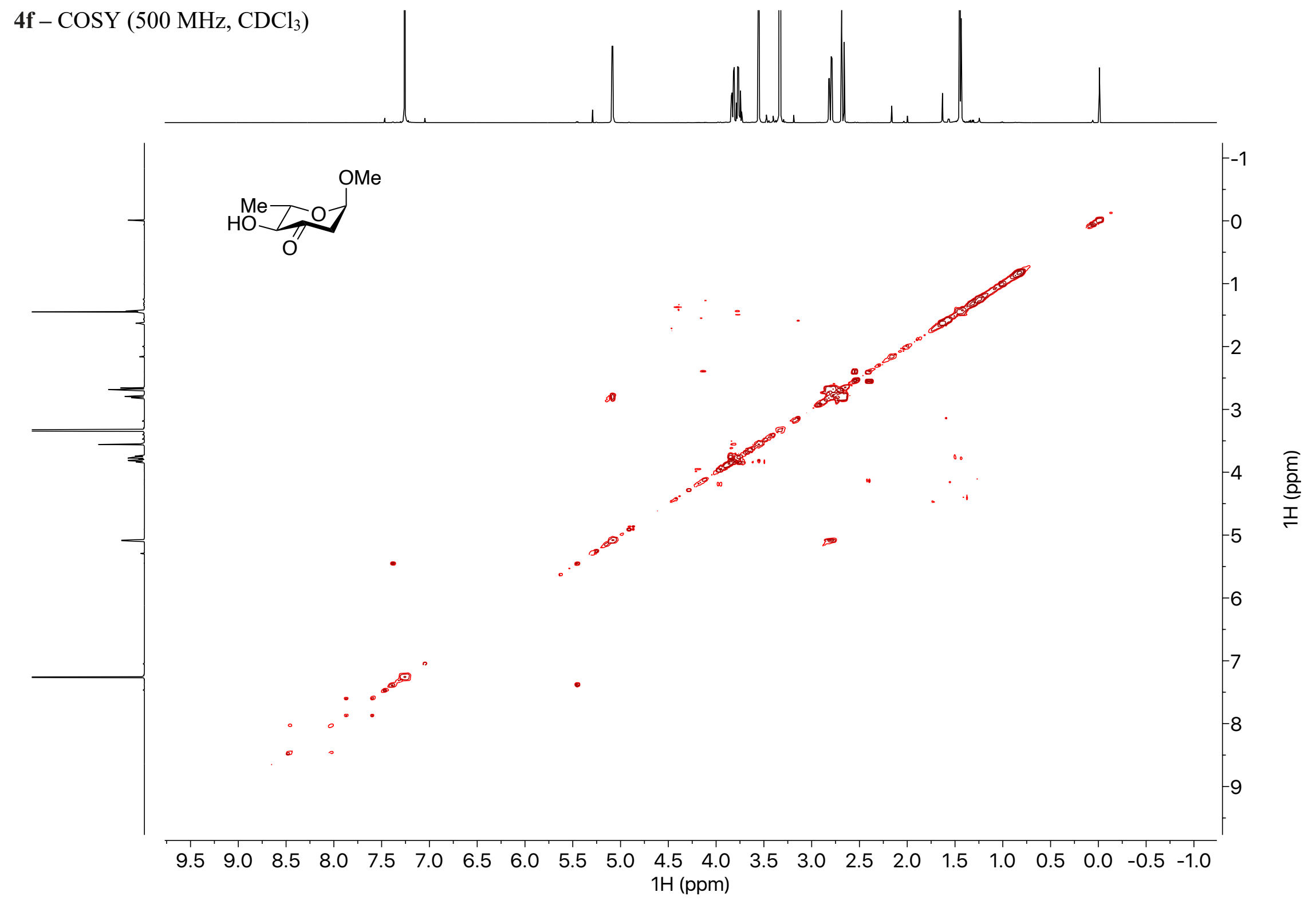


4g - Cyclohexyl 2,6-dideoxy- $\alpha$-D-erythro-hexopyranoside-3-ulose

${ }^{1} \mathrm{H} \mathrm{NMR}\left(500 \mathrm{MHz}, \mathrm{CDCl}_{3}\right.$ )

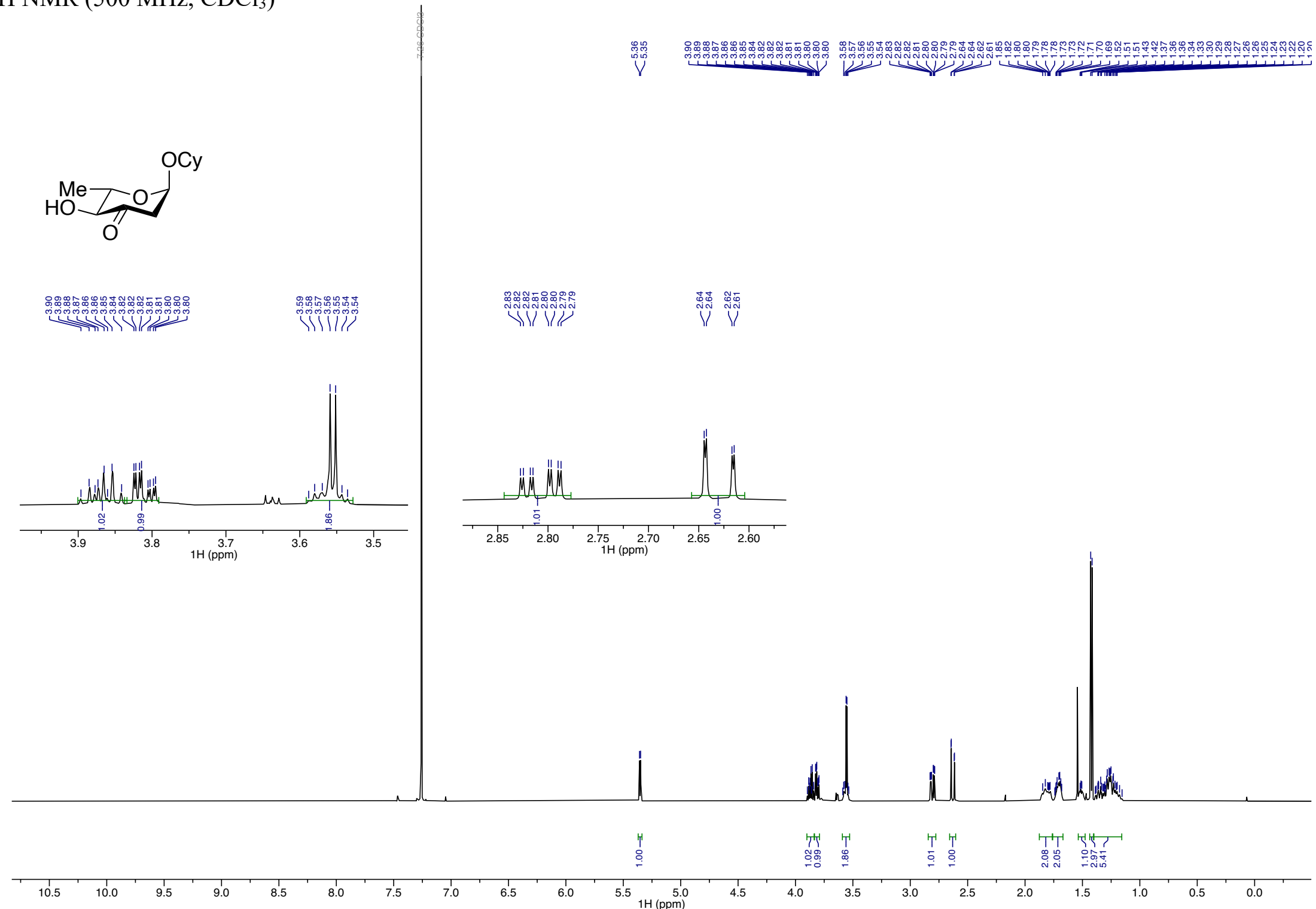


$4 \mathrm{~g}-{ }^{13} \mathrm{C}$ NMR $\left(500 \mathrm{MHz}, \mathrm{CDCl}_{3}\right)$
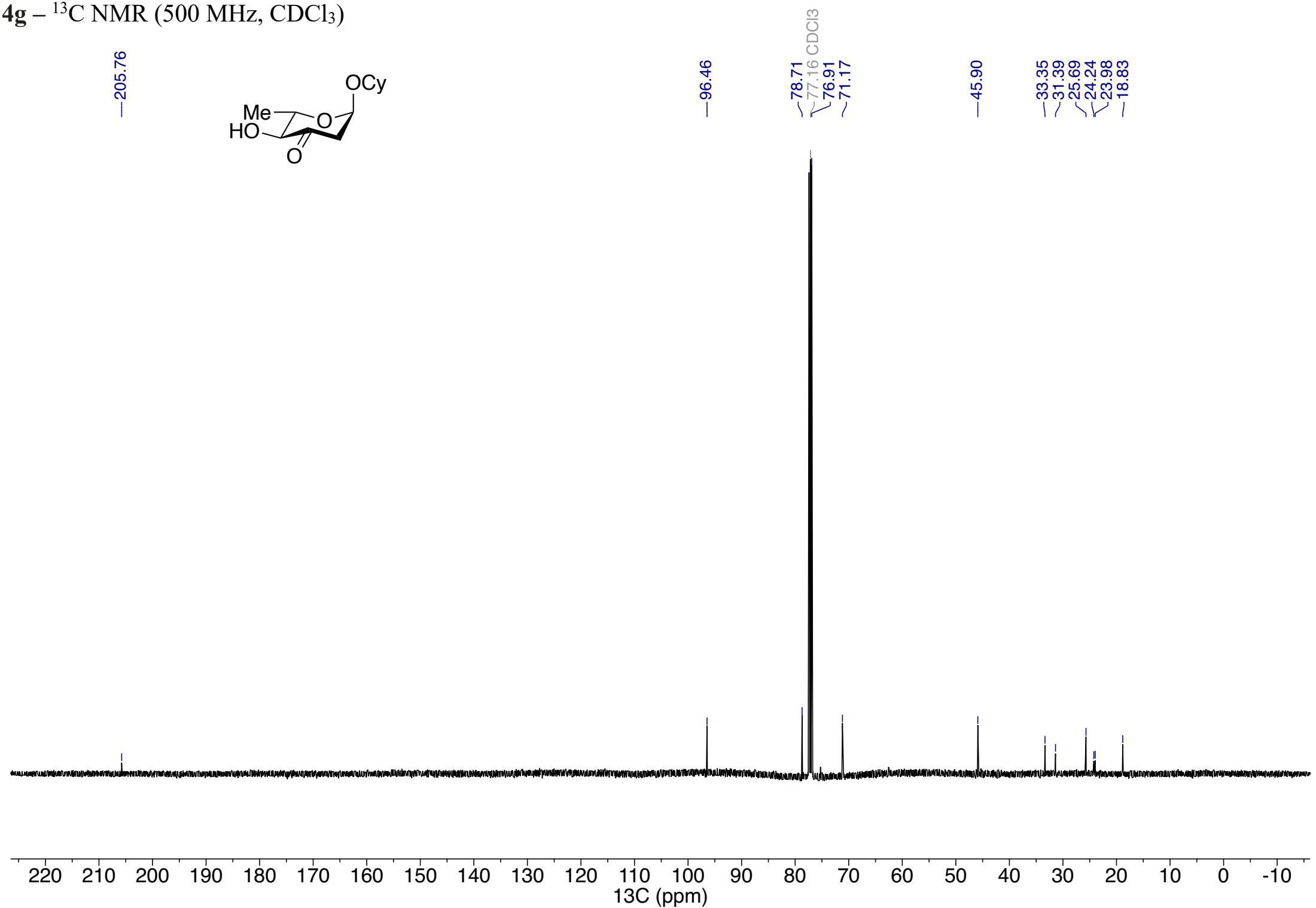
$4 \mathrm{~g}-\mathrm{COSY}\left(500 \mathrm{MHz}, \mathrm{CDCl}_{3}\right)$

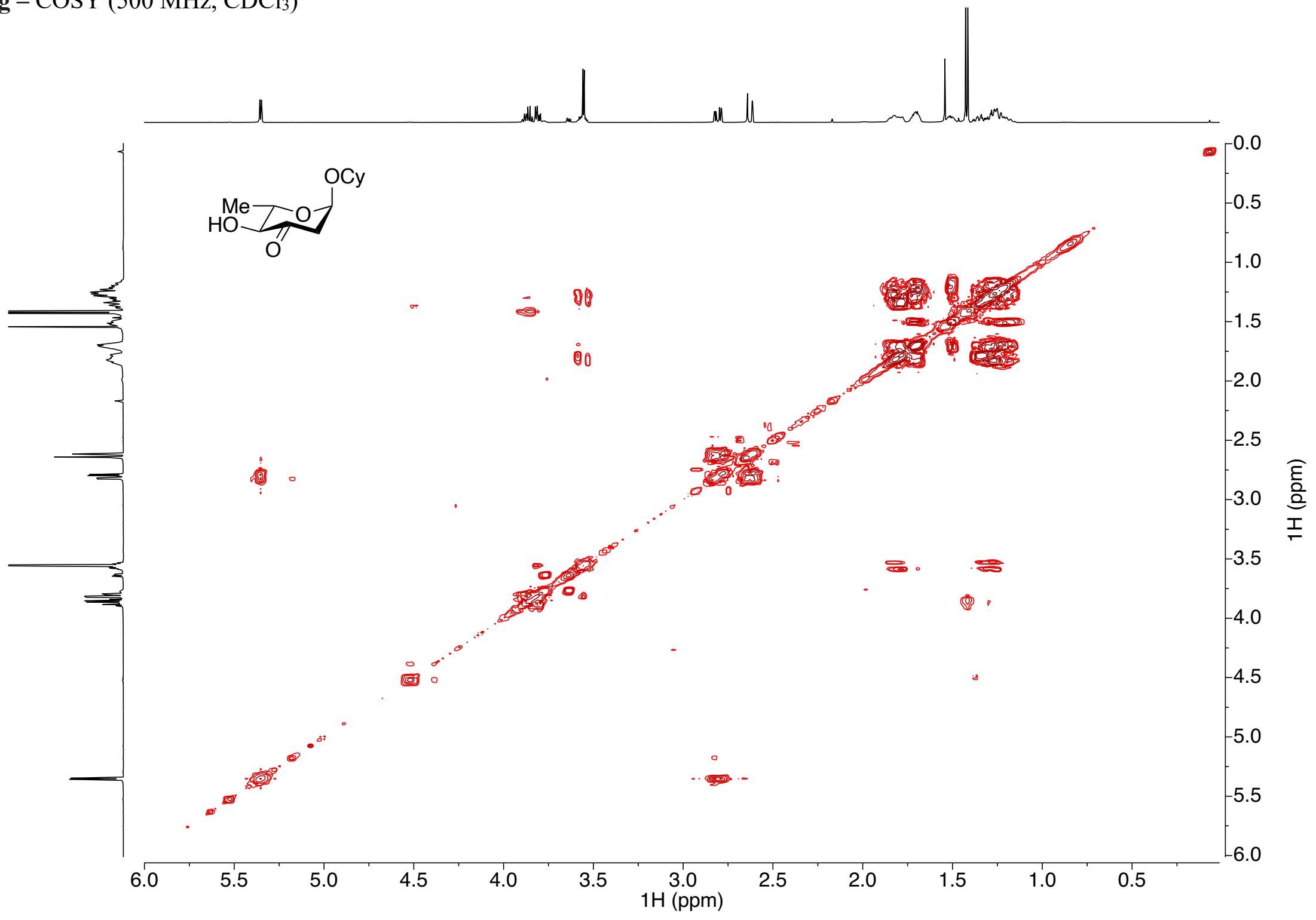

S193 
4h - 1,2,3,4-di-O-isopropylidene-6-O-(2,6-dideoxy- $\alpha$-D-erythro-hexopyranoside-3-ulosyl)- $\alpha$-D-galactopyranoside ${ }^{1} \mathrm{H} \mathrm{NMR}\left(500 \mathrm{MHz}, \mathrm{CDCl}_{3}\right)$
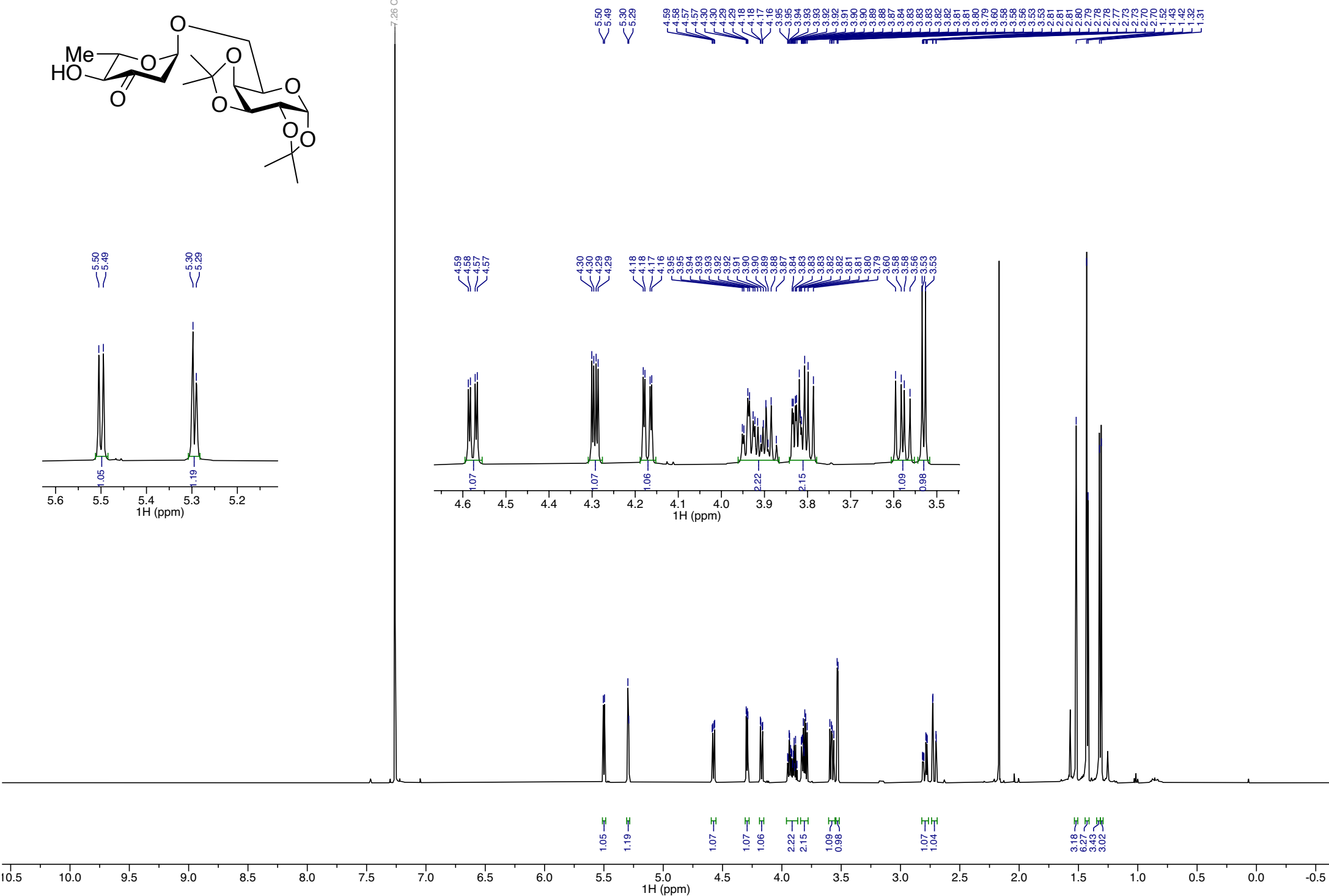
4h $-{ }^{13} \mathrm{C}$ NMR $\left(500 \mathrm{MHz}, \mathrm{CDCl}_{3}\right)$

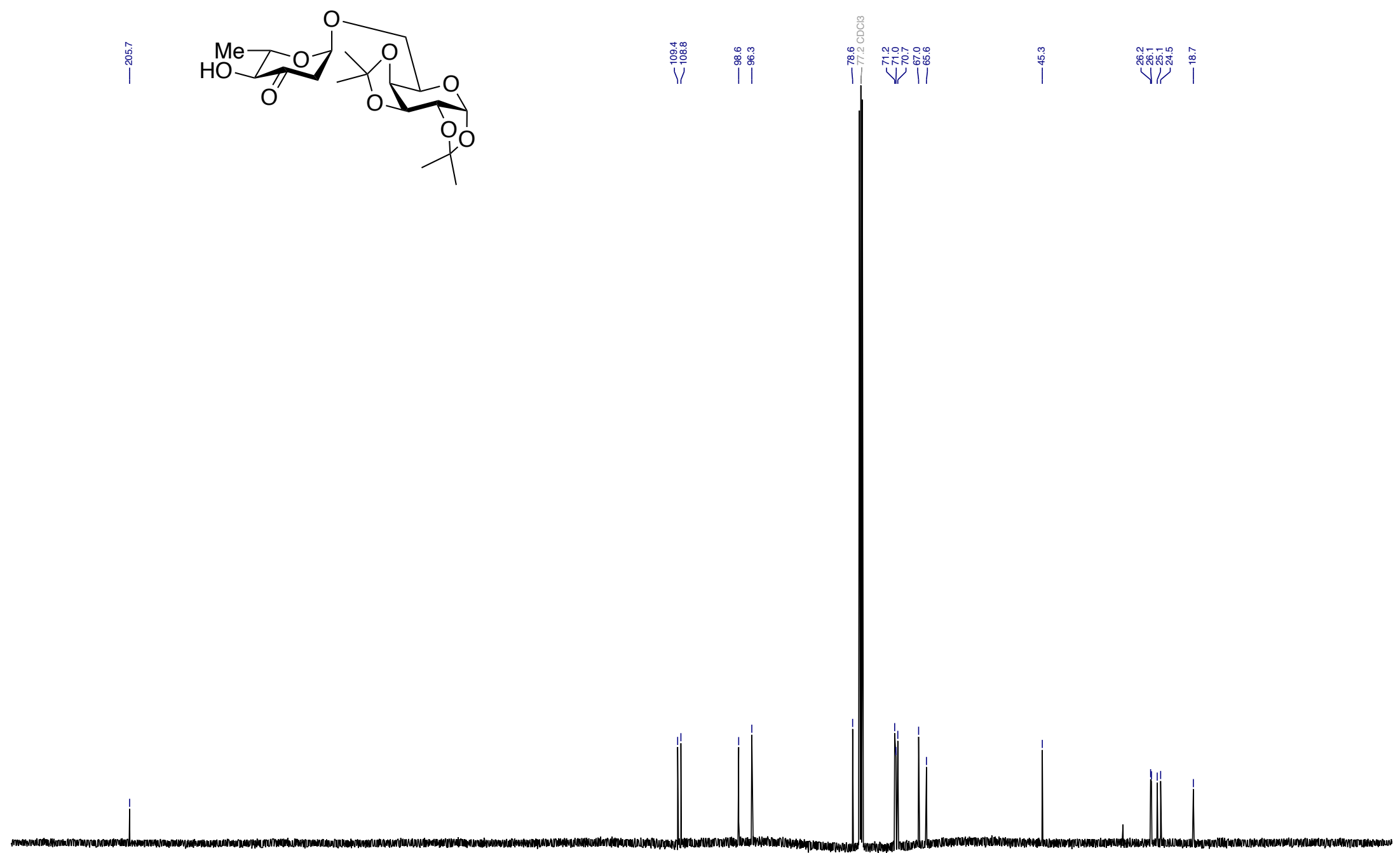

$220 \quad 210$

$200 \quad 190$

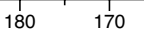

160

$150 \quad 140$

130

${ }_{13 \mathrm{C}}^{110}\left(\begin{array}{r}100 \\ \mathrm{ppm})\end{array}\right.$

80

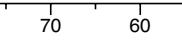

50

30

S195 
4h $-\operatorname{COSY}\left(500 \mathrm{MHz}, \mathrm{CDCl}_{3}\right)$

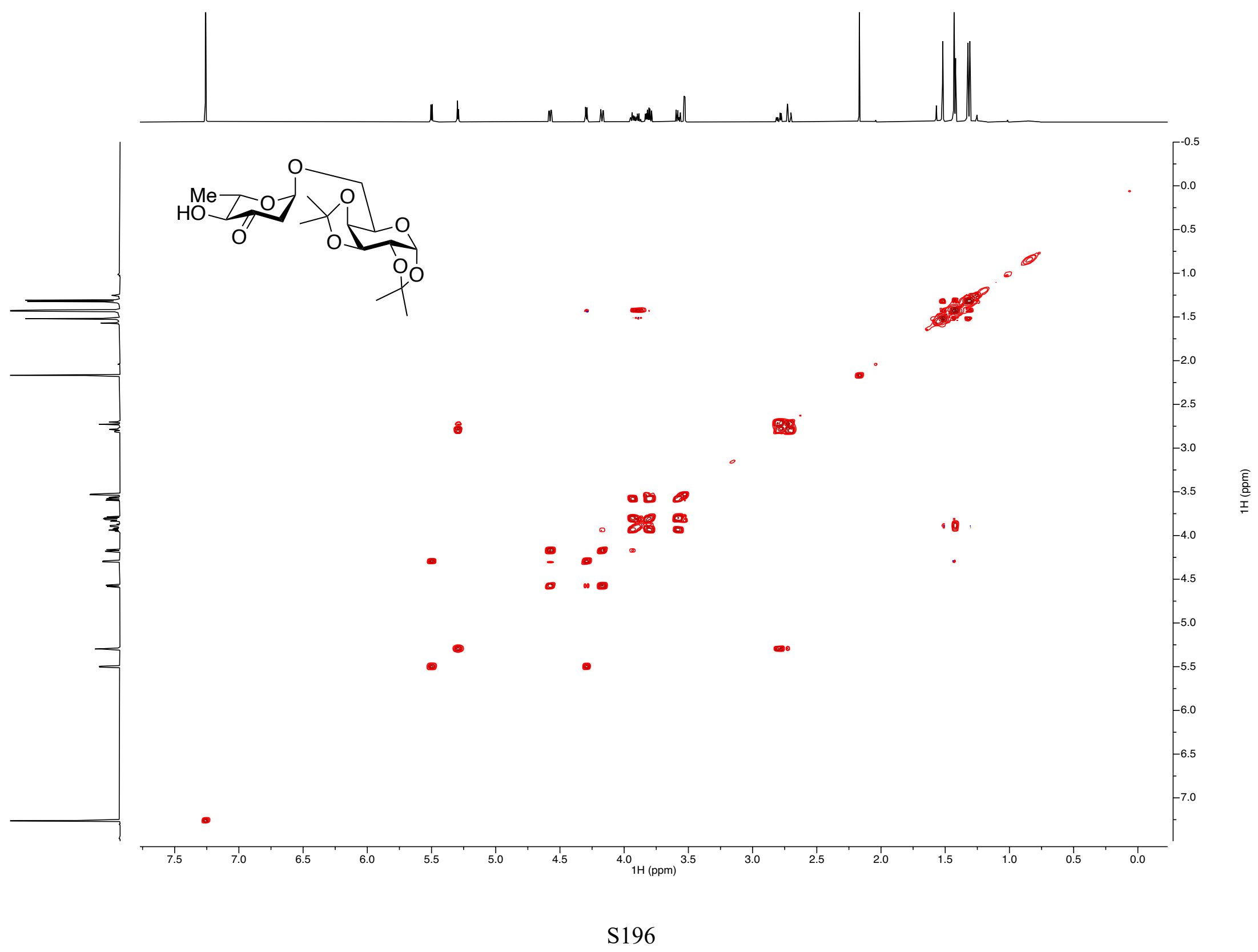




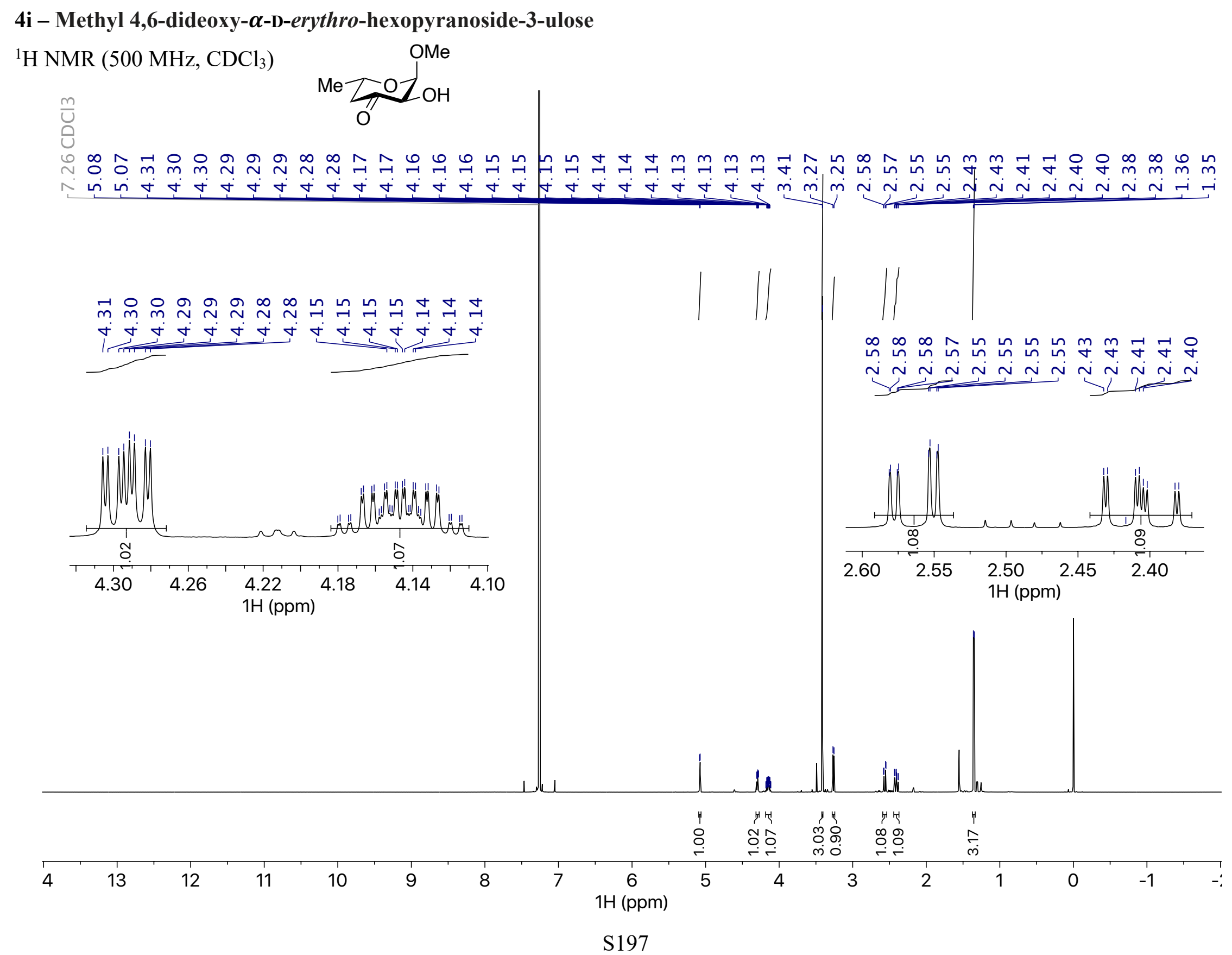


4i $-{ }^{13} \mathrm{C}$ NMR $\left(126 \mathrm{MHz}, \mathrm{CDCl}_{3}\right)$

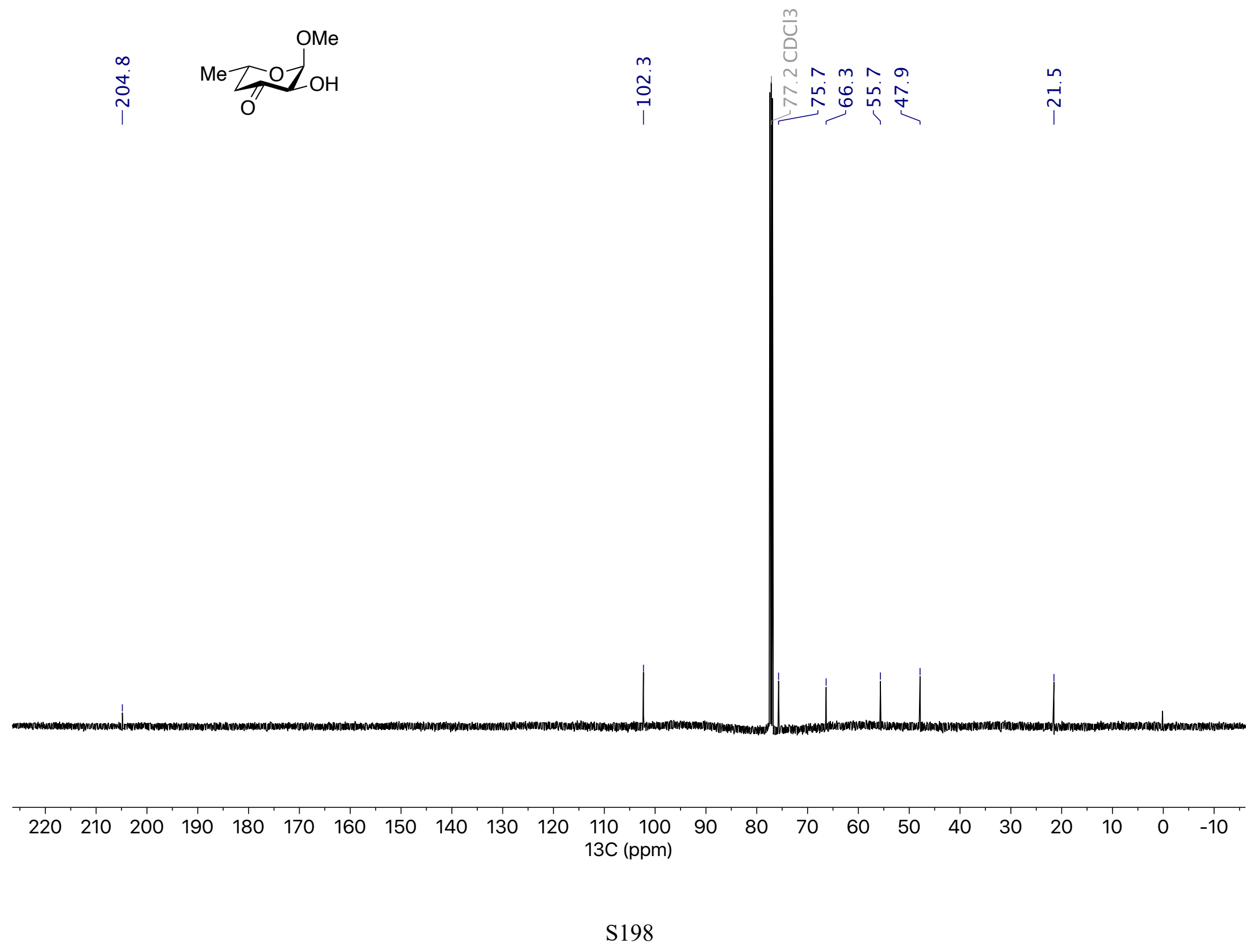




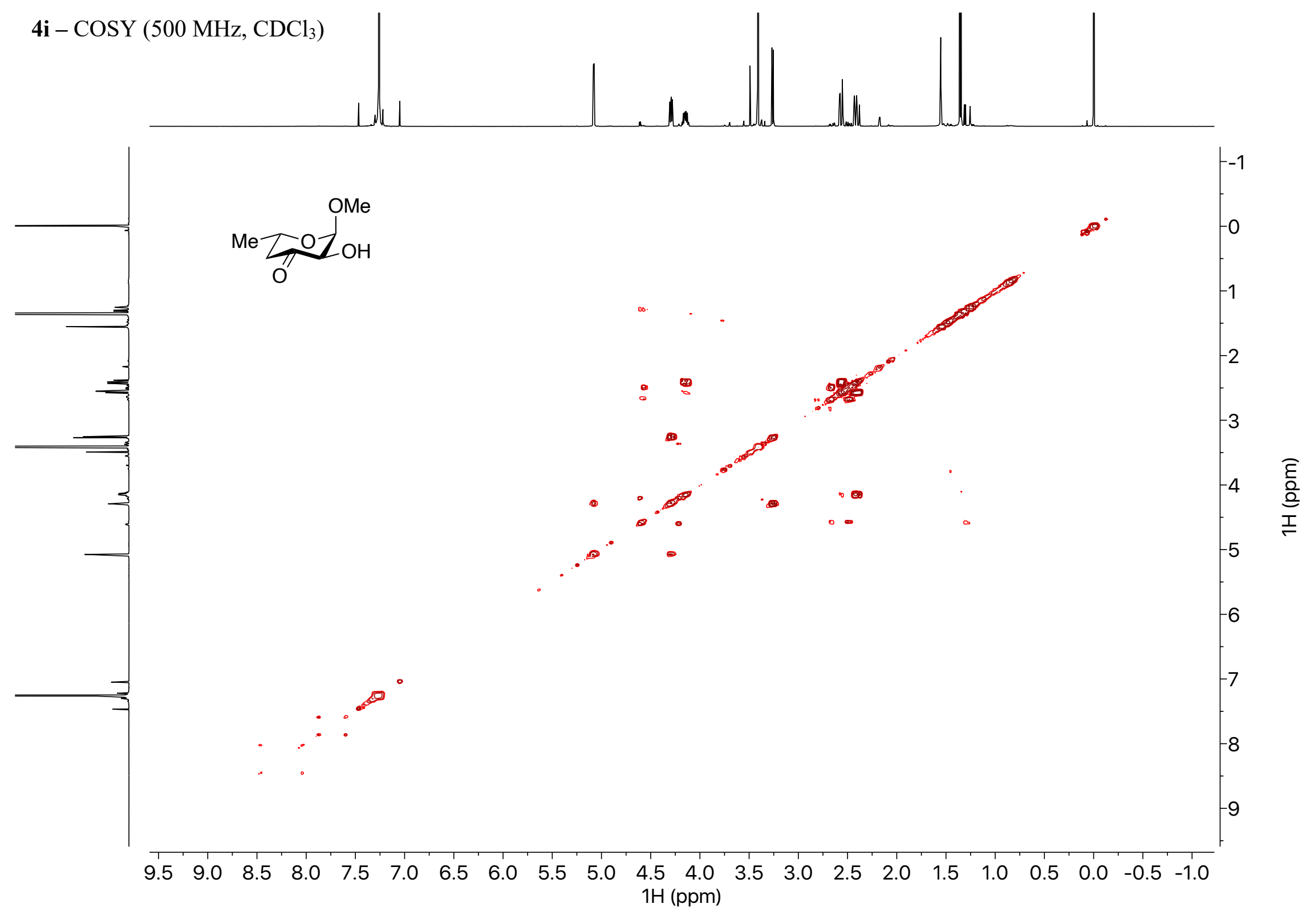

S199 